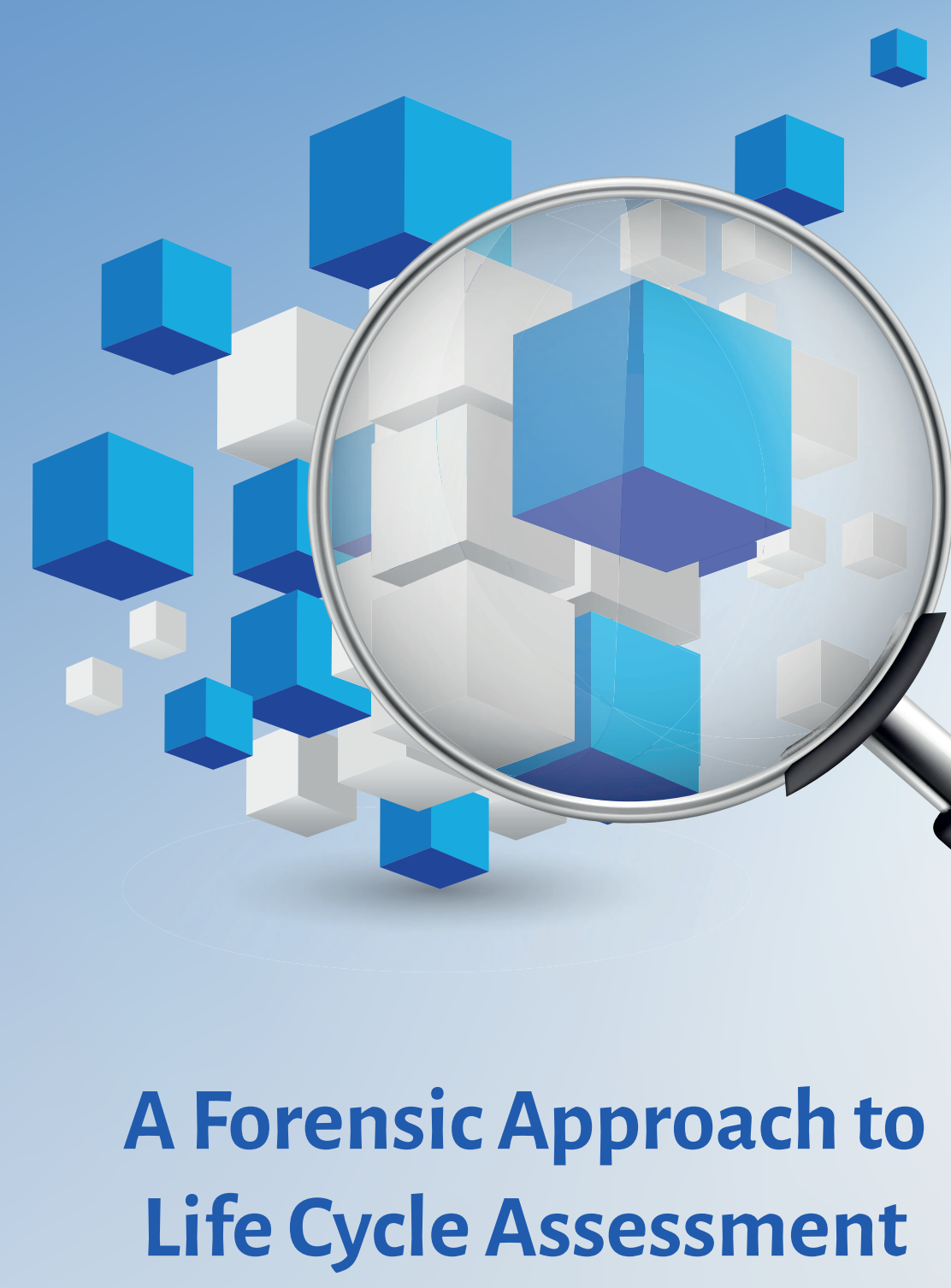

Addressing the challenges of product economic inventory data collection for LCA input, in support of product comparative environmental claims

Alan Stuart Campbell 


\section{A FORENSIC APPROACH TO LIFE CYCLE ASSESSMENT}

ADDRESSING THE CHALLENGES OF PRODUCT ECONOMIC INVENTORY DATA COLLECTION

FOR LCA INPUT, IN SUPPORT OF PRODUCT COMPARATIVE ENVIRONMENTAL CLAIMS

Alan Stuart Campbell 


\section{A FORENSIC APPROACH TO LIFE CYCLE ASSESSMENT}

ADDRESSING THE CHALLENGES OF PRODUCT ECONOMIC INVENTORY DATA COLLECTION FOR LCA INPUT, IN SUPPORT OF PRODUCT COMPARATIVE ENVIRONMENTAL CLAIMS

\section{DISSERTATION}

to obtain

the degree of doctor at the University of Twente, on the authority of the rector magnificus,

prof.dr. T.T.M. Palstra, on account of the decision

of the Doctorate Board,

to be publicly defended on

Wednesday, 27th November 2019 at 12:45 hours

by

\section{Alan Stuart Campbell}

born on 18th February 1960

in Preston, UK 
This dissertation has been approved by:

\section{Supervisor:}

prof.dr.ir. R. ten Klooster

\section{Co-supervisor:}

prof.dr.ir. F.J.A.M. van Houten

Cover design: Stefanie van den Herik | www.herikmedia.nl

Printed by: ProefschriftMaken | www.proefschriftmaken.nl

Lay-out: ProefschriftMaken | www.proefschriftmaken.nl

ISBN: 978-94-6380-571-1

DOI: 10.3990/1.9789463805711 | https://doi.org/10.3990/1.9789463805711

(C)2019 Alan Stuart Campbell, The Netherlands. All rights reserved. No parts of this thesis may be reproduced, stored in a retrieval system or transmitted in any form or by any means without permission of the author. Alle rechten voorbehouden. Niets uit deze uitgave mag worden vermenigvuldigd, in enige vorm of op enige wijze, zonder voorafgaande schriftelijke toestemming van de auteur. 
GRADUATION COMMITTEE:

Chairman/secretary prof. dr. G.P.R.M. Dewulf, University of Twente

\section{Supervisor \\ Co-supervisor}

Members prof. dr. ir. R ten Klooster, University of Twente prof. dr. ir. F.J.A.M. van Houten, University of Twente

prof. dr. I. Gibson, University of Twente prof. dr. ir. T.H. van der Meer, University of Twente prof. dr. E. Worrell, Utrecht University prof. dr. ir. J.C. Brezet, Aalborg University prof. dr. M.Z. Hauschild, Technical University of Denmark prof. dr. ir. M. Buntinx, Hasselt University 
Acknowledgements $\quad 15$

Summary $\quad 17$

Samenvatting $\quad 25$

$\begin{array}{ll}\text { PART 1 } & 35\end{array}$

Chapter 1 - Introduction to the Study 37

1.1 Introduction $\quad 39$

1.2 Environmental Claim Statements $\quad 40$

1.3 The Use of Life Cycle Assessment 43

1.4 Food Service Disposables (FSD) as the Product Choice for this Study 47

1.5 Central Research Question 49

1.6 Structure of the Thesis 51

Chapter 2 - Food Service Disposables and Environmental Claim Statements 53

2.1 Introduction $\quad 55$

2.2 History of FSD 55

2.3 FSD and Public Health 58

2.4 The Food Service Sector and Market Size $\quad 59$

2.5 Resource Size of FSD 65

2.6 The Supply Chain from Raw Material to FSD 67

2.7 Definition and Characteristics of FSD 70

2.8 The Current Environmental Claim Statements applied to FSD 71

2.9 Comparative Banded Scale based Claim $\quad 72$

2.10 Comparative Banded Scale for FSD 73

2.11 Initial Goal and Scope of a Comparative Product Study 75

2.12 FSD Stakeholders $\quad 76$

2.12.1 Stakeholders in Practice 76

$\begin{array}{ll}2.13 \text { Chapter } 2 \text { Conclusions } & 77\end{array}$

Chapter 3 - Life Cycle Assessment (LCA) 79

3.1 Definition of Life Cycle Assessment 81

3.2 The History of Life Cycle Assessment 81

3.3 Life Cycle Assessment Standardized Procedure 82

3.4 LCA - Uncertainties and Factors influencing their Result 84

3.4.1 Impact Assessment Method 84

3.4.2 Weighting 85

3.4.3 Allocation 85

3.4.4 Uncertainty 85

3.4.5 Process Datasets 86

3.5 LCA - Streamlined LCA 86

3.6 Chapter 3 Conclusions 86 
Chapter 4 - Comparative Environmental Claim Statements

4.1 Introduction $\quad 89$

4.2 Rules governing the Design of Comparative ECS 89

4.2.1 ISO 14025:2006 90

4.2.2 PEFCR 91

4.2.3 EPD 93

4.2.4 Conclusion from PEFCR, EPD and ISO 14025 as relates to LCA Input 95

4.2.5 Observations Derived from the Conclusions in Chapter 4.2.4 96

4.3 Resulting Challenges to Address in Developing a Comparative ECS 96

4.3.1 Comparison and Functional Unit $\quad 97$

4.3.2 Product and Material Composition $\quad 97$

4.3.3 Country of Origin (CoO) 97

4.4 Chapter 4 Conclusions 98

Chapter 5 - Sourcing and Collecting Product Life Cycle Inventory Data 101

5.1 Introduction $\quad 103$

$\begin{array}{ll}5.2 \text { Method of Research } & 104\end{array}$

$\begin{array}{ll}\text { 5.2.1 Scientific Research } & 104\end{array}$

5.2.2 Questionnaire 107

5.2.3 Discussions with Packaging LCA Experts 108

5.2.4 Web Tool Research 108

5.2.5 Commercial LCA Tool Research 109

5.2.6 Further Web based General Research 109

5.3 Chapter 5 Conclusions 110

Review of Conclusions from Part 1

$\begin{array}{ll}\text { PART } 2 & 113\end{array}$

Chapter 6 - Applying the ReCiPe Approach, and Defining a

Suitable Scoring System 117

6.1 Introduction $\quad 119$

6.1.1 The Intended Audience, Goal and Scope of the Comparative ECS 119

6.1.2 Scoring Systems to Identify Movements in Relative Position

6.2 Numerical Value Indicator $\quad 120$

6.2.1 ReCiPe 121

6.3 Use of the Ratio to the Mean as a Ranking Indicator 124

6.4 Rank Order Indicator $\quad 125$

6.5 Star Rating Indicator $\quad 125$

6.5.1 Star Rating Indicator Method $\quad 125$

6.6 The Effect of Impact Assessment Methodology Choices $\quad 128$

6.6.1 ReCiPe 131 
6.6.2 Impact 2002+ 132

6.6.3 IPCC 2013 - GWP 100a 134

6.6.4 An Overview of the above Impact Assessment Methodologies 135

6.7 The Effect of Setting Bands 136

6.8 The Effect of Different Inventory Collection Approaches of Multiple Products within a Category 136

$\begin{array}{ll}\text { 6.9 Chapter } 6 \text { Conclusions } & 136\end{array}$

Chapter 7 - The Functional Unit 139

7.1 Introduction $\quad 141$

7.2 Function, Functional Specification, Product Functionality Rules
and Functional Unit

7.2.1 Consideration of Functional Unit in Scientific Research 144

7.3 An Approach to Formulating PFR for FSD 146

$\begin{array}{ll}\text { 7.3.1 Product Type } & 146\end{array}$

$\begin{array}{ll}\text { 7.3.2 Market } & 146\end{array}$

$\begin{array}{ll}\text { 7.3.3 Territory } & 146\end{array}$

$\begin{array}{ll}\text { 7.3.4 Date } & 147\end{array}$

7.3.5 Product Functionality 147

7.3.6 Product Primary Category 147

7.3.7 Primary Category Product Testing 147

7.3.8 The Final Product Category 147

7.4 Examples of Methods for Establishing the Like Functionality of

FSD Being Compared 148

7.4.1 Example Testing of FSD in relation to their Function 148

7.4.1.122cm Diameter Plates Testing Method 151

7.4.1.1.1 Retainer Clamp 152

7.4.1.1.2 Force $\quad 152$

7.4.1.1.3 Displacement $\quad 153$

7.4.1.1.4 Displacement PFR 153

7.4.2 Other Examples of Properties included in PFR, as might relate $\begin{array}{ll}\text { to Beverage Cups } & 154\end{array}$

7.4.3 Limits to PFR 155

7.5 A More Detailed Review of the Effect of PFR for a Category of Plates 156

$7.6750 \mathrm{ml}$ Take-Out Meal Tray - A Study of a Category with Very

Diverse Product Types 159

7.6.1750ml Take-Out Meal Tray - Functional Unit 161

7.7 Methods to Establish PFR to Categorise a group of Apparent
Like Functionality Products

7.7.1 Goal defined Category PFR 162

7.7.2 Scope defined Category PFR 162

7.7.3 CPA defined Category PFR 162

$\begin{array}{ll}\text { 7.7.4 Label defined Category PFR } & 163\end{array}$ 
7.7.5 Categories PFR based on the Function of the Demonstration Product 163

7.7.6 Category PFR based on the Average Functionality of the Primary Category

7.7.7 Category PFR based on Territory Considerations

Chapter 8 - FSD Material Composition Identification for LCA Input

8.1 Introduction

8.2 Materials Identification

8.2.1 Instrumentation Requirements

8.2.2 Materials Identification

8.3 Conversion Process Identification

8.3.1 Generic Data versus Specific Data

8.4 The Value of Component Identification as LCA Input 182

8.5 Level of Resolution in Component Identification for LCA Input 184

8.6 Chapter 8 Conclusions

\section{Chapter 9 - Country of Origin (CoO) Identification for LCA Input}

9.2 To What Extent is the CoO Likely to be Unknown with regard to FSD 190

9.3 The Effect of the Lack of CoO Knowledge 191

9.3.1 Lack of CoO Knowledge regarding Raw Material Generic Data Choices

9.3.2 Lack of $\mathrm{CoO}$ Knowledge regarding Conversion Process Generic Data Energy Choices

9.3.3 Lack of CoO Knowledge regarding Transport Distance and Type Data Choices

9.3.4 Lack of CoO Knowledge - Conclusion

9.4. Proposed Solutions to the Issue of a Lack of Knowledge as to

the Country of Origin of a Product

196

9.4.1 Expert Knowledge Based Simple Approach

9.4.2 FTIR/XRF Based Detailed Approach

9.4.3 Isotope Ratio Mass Spectrometry based Detailed Approach

9.4.4 The Overlap between both Spectrometry Approaches and the

Expert Knowledge Approach

\section{Chapter 10 - The Role of Relevant Product and Technology Knowledge and Issues of its Interpretation 205}

$\begin{array}{ll}10.1 \text { Introduction } & 207\end{array}$

10.2 Knowledge 209

10.2.1 Technologically Relevant Knowledge 209

10.2.2 The Technologically Relevant Knowledge of the LCA Operative 209

10.2.3 Example of Cup Studies involving a Lack of

Technologically Relevant Knowledge 
10.2.3.1 Example of Likely Demonstration Cup 213

10.2.3.2 Example of Hocking Demonstration Cup 214

10.2.3.3 Example of DFE Demonstration Cup 214

10.2.3.4 Example of OVAM Target Cup 217

10.2.3.5 Other Issues regarding Cup Studies $\quad 217$

10.2.3.6 Conclusion Cups 219

10.2.4 Example of Lack of FSD Technologically Relevant Knowledge

$10.322 \mathrm{~cm}$ Plates - Process Waste 221

10.3.1 22cm Plates - Process Waste - Conclusion 223

10.4 8oz Double Wall Paper Cup and Lid 225

10.4.1 The Lid 226

10.4.2 The Outer Cup of the Double Wall 8oz Cup 228

10.4.3 The Inner Cup of the Double Wall 8oz Cup 231

10.4.4 The Complete 8oz Double Wall Paper Cup and Lid 231

10.4.5 Further Examples of Materials Variance in Double Wall Paper Cup 235

10.4.6 Conclusions - Double Wall Paper Cup 237

10.5 Market Knowledge $\quad 237$

10.6 The Claim Maker 239

10.7 Chapter 10 Conclusions 239

Review of Conclusions from Part 2 241

$\begin{array}{ll}\text { PART } 3 & 243\end{array}$

Chapter 11 - Testing FUMCO across a Range of Food Service Disposables 245

11.1 Introduction 248

11.2 Test No.1 - Disposable Plastic Beverage Drinking Glasses for Cold Drinks 248

11.2.1 Cold Beverage Glasses - Functional Unit 250

11.2.2 Cold Beverage Glasses - Material Composition 259

11.2.3 Cold Beverage Glasses - Country of Origin 262

11.2.4 Cold Beverage Glasses - Knowledge 265

11.2.5 Cold Beverage Glasses - Conclusion 265

11.3 Test No.2 - Across Multiple FSD types 266

11.3.1 Functional Specification Identification - FSD Spoon 266

11.3.2 Material Composition Identification - FSD Soup Bowl 269

11.3.3 Country of Origin Identification - FSD Take-Out Meal Tray 270

11.3.4 Technologically Relevant Knowledge Valuation as related to
the Test No.2 Products

$\begin{array}{ll}11.4 \text { Chapter } 11 \text { Conclusions } & 274\end{array}$ 
Chapter 12 - Expert Opinion, Discussions and Considerations

12.1 Expert Opinion $\quad 279$

12.1.1 The LCA Experts Interviewed 280

12.1.2 Expert - Email Questionnaire 280

12.1.3 The LCA Expert Interviews 281

12.1.3.1 Expert Introductory Comments 283

12.1.3.2 Expert Functional Unit based Comments 284

12.1.3.3 Expert Material Composition based Comments 284

12.1.3.4 Expert Country of Origin based Comments 285

12.1.3.5 Expert Product Technologically Relevant Knowledge based Comments 286

12.1.4 An Overview of the Experts' Comments - Other Points of Interest 287

12.1.5 Conclusions of the LCA Experts 288

12.1.6 Discussions in Response to the Comments of the LCA Experts 288

12.2 Chapter 12 Conclusions 291

Chapter 13 - Study Conclusions 293

13.1 Introduction 295

13.2 Findings of the Research 297

13.3 The Primary Research 301

13.4 The FUMCO Method 301

13.5 Practical Limitations of FUMCO 302

13.6 Further Observations Derived from the Research 304

13.6.1 Relevance of the Use of LCA to the Decision to be Made 304

13.6.2 FUMCO Role in Establishing the Goal and Scope of an LCA 305

13.7 Value of the Study, and to Whom 306

13.8 Contribution to Knowledge 307

13.9 Learnings regarding Environmental Claim Statements 308

13.10 Environmental Claim Statements - Addressing the Issue of
Product Economic Inventory Collection

$\begin{array}{ll}\text { 13.10.1 Function } & 310\end{array}$

13.10.2 Material Composition $\quad 310$

13.10.3 Country of Origin 311

13.10.4 The Environmental Claim Statement 312

13.11 Environmental Claim Statements - Recommendations on How

13.12 Recommendations for Future Research 313

$\begin{array}{ll}\text { References } & 317\end{array}$

Scientific References $\quad 317$

Non-scientific References $\quad 332$ 
Appendices

Appendix A

Appendix B

Appendix C

Appendix D

Appendix E

Appendix $F$

Appendix G

Appendix $\mathrm{H}$

353

Appendix I

354

Appendix J

355

Appendix K

356

Appendix L

358

Appendix M

359

Appendix N

360

Abbreviations

373 


\section{Acknowledgements}

I am keen to acknowledge the many people who have supported and contributed, directly and indirectly, to this study. It is neither practical nor feasible to mention them all by name but I would nevertheless like to express my gratitude to everyone who helped me through the process.

There are, however, some people without whom it would have been very difficult to pursue this research. They therefore deserve a special mention and a huge thank you:

To my wife, Kim, for her acceptance of my absence from family life during what should have been our free time and for her contribution, especially in the final publishing stage of the study. Likewise, to my three wonderful children Oliver, Adam and Elena plus my daughter-in-law Unn who worked on many of the diagrams within the text.

To my mentor, Professor Roland ten Klooster, who has been extremely patient and encouraging throughout this long journey.

To my Scottish team, made up of my father and Professor Alan Roach, both of whose guidance, commitment, logic and diligence was vital. Plus again to my father for believing I could do it.

To the Paardekooper family, Jan, Monica and Lyanne, the owners of the Packaging LCA Centre, whose vision as regards packaging and the environment is unmatched.

To my paranymphs and great colleagues Agnieszka van Batavia and Loek Waegemaekers for continuously challenging me and for Loek's patience in translating my summary.

To my colleagues at Natuur \& Milieu, Jan Fransen and Jelmer Vierstra.

To colleagues Eric Lutters, Jos de Lange and Inge Dos Santos-Smit at the University of Twente for their kind guidance.

To the PhD committee for taking the time to assess my research.

To my friend and fellow PhD student Robert Young for his encouragement.

As stated above, it is impossible to name everyone and for that I apologize.

Environmental issues as relates to packaging make it an exciting time to work in an industry that I have been involved in my whole life, having been born into a packaging family. I hope that my knowledge will be of use in addressing these issues and working towards a brighter future for packaging.

Thank you 


\section{Summary}

Many people buy food and drink while on the move; these are mostly provided in single use articles, so-called food service disposables (FSD). It is recognized that this popular activity inevitably has environmental impacts, and there is widespread interest in quantifying and seeking to minimize such impacts. FSD articles are supplied through a very competitive international market and suppliers often seek to gain advantage by making competitive claims about their own products. When looking at coffee cups, for example, claims can be found that are printed across a wide range of different cups. Many claims refer to aspects of the environment, as we live in a period in which there is a virtual tsunami of environmental claims.

A common question is "Which one of these products has the lowest environmental impact?". How to address this question is of interest. It would suggest products of similar function need to be compared as regards an environmental aspect, and then ranked if the comparative assessment can be quantified.

Environmental claims of various types are commonly found on many types of FSD. FSD provide an ideal medium to understand the implications of establishing a comparative environmental claim statement (ECS). Their life cycle could be said to have no specific use-phase charge on the environment, keeping the life cycle inputs and outputs relatively simple. The prevalence and growth in the use of FSD globally could indicate a large resource use that is of value to study with regard to ECS.

It should be noted that there are many different categories of environmental impacts, including, inter-alia, contributions to atmospheric $\mathrm{CO}_{2}$ levels, resource depletion and environmental contamination. In order to derive an assessment that is of practical use to consumer purchasers of FSD, it is widely agreed that a single overall measure should be derived, such as can be communicated via an ECS rating. This involves an agreed method of weighting measures of different impact types and subsequently adding these to give a single overall measure. The model used to achieve this lies at the heart of the assessment method selected.

The most relevant of ECS claims might be those that seek to establish the relative environmental difference between products of like functionality. Approaches to these claims, such as described in International Organization for Standardization (ISO) 14025 or the EU Product Environmental Footprint Category Rules (PEFCR), require the use of Life Cycle Assessment (LCA) and seek stakeholder cooperation in order to access product economic inventory data for input to LCA.

LCA is adopted as the appropriate source of the quantification that could permit the identification of the "lowest environmental impact" product in the above question. 
This study sets out to research those issues that need addressing when developing a reliable comparative ECS for FSD, quantified through LCA. Research shows that product economic inventory data in published LCA studies of FSD products are often erroneous. This study demonstrates the need to use accurate inventory data to ensure the reliability of the final ranking of a product within a comparative ECS. This led to the central research question:

\section{CRQ: Is it possible to develop a method to optimize the quality of product economic inventory LCA input data, in support of product LCA based comparative claims, in the presence and absence of stakeholder cooperation?}

The term "stakeholders" refers to the manufacturers and suppliers of the FSD being assessed, who stand to benefit if their products earn favourable rankings.

A review of literature associated with ECS, FSD, LCA, comparative ECS and current methods of product economic inventory collection was executed. It showed that FSD regularly display an ECS and that such a claim with context, a product comparative claim, would be useful, this claim being ideally based on LCA. LCA based claim methods, such as Product Environmental Footprint (PEF), Environmental Product Declaration (EPD) and various relevant ISO standards, were reviewed. A study of the current methods of product economic inventory data collection was carried out using literature and a questionnaire mailing to LCA experts.

FSD are significant in terms of their hygienic benefits, convenience, commercial value and resource size. FSD are derived from a variety of competing sources, made of a wide range of materials and composites, involving a wide range of conversion processes, to perform a like functionality service. FSD materials cover papers, boards, plastics, composites and woods, with their various conversion processes, such as injection moulded PS cups or extrusion coated and printed paper board that is cut, formed and sealed into the iconic paper cup.

FSD could be defined as products of minimalistic fit-for-purpose design, using the minimum of resource for their single use function of providing the sanitary consumption of food and drink while on the move.

Research into FSD showed that there are few scientific sources, with few economic market overviews. The supply chain is hourglass shaped, with many producers, far fewer importers and many users who provide FSD to the food service customer.

FSD are being questioned in environmental terms, due to their throw-away or disposable nature, and are commonly associated with environmental claims that often appear inane or misleading. 
A comparative claim, such as the EU Directive 92/75/EC energy-labelling scheme, is cited as providing a contextual relevance that is understandable to consumers. If such a comparative ECS is to be studied for application to the embodied environmental impacts of FSD, there may be significant challenges due to the FSD supply chain complexity, and the wide range of materials and processes in their manufacturing. It has also been questioned whether it would be possible to rationally select product categories for comparison.

As can be concluded from the considerable competition in the sector, and as seen in practice, it is also questionable as to whether reliable stakeholder cooperation can be expected from the FSD sector, without which it could be seen to be difficult to identify the product economic inventory input to the LCA required for a comparative ECS.

The range and complexity of issues that this study has had to engage with come from a highly competitive sector with little likely stakeholder cooperation, involving significant consideration as to the functional specification definition, as well as a wide range of materials, processes and product sources.

A study of LCA showed that whether an LCA is made with or without stakeholder cooperation, or with or without specific data, the implication regarding choices of impact assessment method, allocation, uncertainties and LCIA datasets needs to be considered, as they can influence the relative results.

Research was carried out into the rules governing the design of LCA based ECS, specifically PEFCR, EPD and ISO 14025. It was concluded that PEFCR, EPD and ISO 14025 are approximately in line. The following three aspects came out as being of importance, as regards the product economic inventory input to LCA:

1. Definition of the Functional Unit (FU)

2. Material Composition (MC) and its associated conversion processes

3. Country of Origin (CoO)

Insight into the supply chain and FSD technologically relevant knowledge are critical aspects that also need consideration.

Research was carried out into the sourcing and collecting of product economic inventory data for input into LCA. It is cited that very little has been written about how to carry out product economic inventory data collection for inclusion into an LCA study. This research involved studies of scientific papers, an email questionnaire to LCA experts, interviews of experts and a study of LCA tool operating manuals. In most cases, as regards these sources, it is assumed that the LCA operative will already have product economic inventory data, without stating the source of the data, hence confirming the cited observation. 
Research identified the use of similar product published LCA studies, technical literature, patents, product sales literature and information available from the internet to identify product economic inventory. Questions were asked as to how accurate this information would be as relates to identifying economic inventory data for a product that could be described from a purely visual examination as mono-material but which, upon instrumentation based analysis, turned out to be a composite material including a range of components.

When comparing a high resolution category of FSD items, all appearing to be made of the same material type from a purely visual examination, it may be that the above mentioned replacement approaches to stakeholder sourced product economic inventory data may not be viable, especially given that FSD products may be made from composite materials not identifiable in a purely visual, or traditional, based study.

To understand the impact of different approaches to product economic inventory collection, a scoring method is required against which the various issues being tested can be judged. Comparison is then made between a category of like functionality FSD products, in which one "target" product in the category is assessed for its associated inventory, firstly using the traditional method of product economic inventory data collection and then using a proposed detailed collection method referred to as FUMCO (an acronym for Functional Unit Material Composition Origin). The changes in relative scoring position of the target product due to a move from traditional to FUMCO inventory collection was then identified.

These differences were studied as relates to product economic inventory data for a collection of products being assessed for their like functionality, their material composition and conversion processes and their country of origin. Literature refers to the existence of a lack of technologically relevant knowledge in LCA operatives as being an issue of concern. Examples of inventory errors in published LCAs were studied and their effects identified.

A method of scoring was introduced against which the various issues being tested could be judged, the proposed methods being required in order to track, test and research the implications of the systems of product economic inventory data collection for comparative claim purposes in the absence of stakeholder input. It is simply a method to demonstrate the effect of changes in how the product economic inventory data is deduced.

As noted above, a single numerical overall environmental assessment must be derived through the LCA methodology adopted. In this work as a whole, the ReCiPe methodology was used, which leads to an "endpoint" numeric value indicator which then serves as the basis of a comparative rating for the products included in any given study.

ReCiPe is a method for the impact assessment in LCA; it is seen as contemporary, widely used and well recognized. The primary objective of the ReCiPe method is to transform lists of Life Cycle Inventory results into a limited number of indicator scores. These indicator scores express the relative severity on an environmental impact category. 
A limited study was also pursued to clarify the impact of using alternative methodologies to ReCiPe. Impact assessment weighting and the setting of bands will influence the relative position of an item within a comparative study. This must be considered when choosing a method and an approach to design a comparative based claim. These alternatives tended broadly to produce similar conclusions to ReCiPe as regards ranking and rating due to changes in product economic inventory input.

The extent to which a product category must be defined for a comparative ECS, made in the absence of the product stakeholders, would appear to require to be exacting, in order to be seen as unbiased and credible. ISO 14025:2006 states that "the function, technical performance and use of comparative products must be identical".

The need for testing or analysis to establish like functionality is introduced, on the basis of a Functional Specification (FS) in the absence of product stakeholders. The exact FS of the product requires defining, and its qualification for inclusion in the category might require significant testing. This testing could be seen to be an objective assessment of compliance to a subjective FU.

Any changes in the definition of the category or product specification or functionality were shown to lead to different results as regards the positioning of the products within a comparative ECS.

Product economic inventory, including material component identification, is required to provide the correct material component qualitative and quantitative input to the LCA used to formulate a comparative ECS. Materials analysis also aids in conversion process identification and has implications for the accounting of transport and end-of-life scenarios.

This research shows the importance of carrying out as full an analysis as possible. The different impacts of the additives, like calcium carbonate $\left(\mathrm{CaCO}_{3}\right)$ and titanium dioxide $\left(\mathrm{TiO}_{2}\right)$ fillers in plastics, is significant, leaving little justification for ignoring either. When there is a difference in outcome, the only justifiable stance is to apply the most thorough analysis available. A less thorough approach could be discredited.

Alternative methods for materials analysis could be seen to be vital in an LCA study, as materials data is often either not available or is from sources that cannot be relied upon. It is evident that taking a simply visual approach to materials identification, sometimes referred to as the traditional approach, may overlook vital materials and processes in the product life cycle.

Research shows that laboratory analytical instrument based materials analysis contributes to increase the potential accuracy of a comparative ECS. It also shows that this type of analysis is time efficient, although the necessary instruments would be required at an initial cost to the operator. 
The effects of the $\mathrm{CoO}$ of an FSD being unknown is shown to have consequences for the relative position of an item within a comparative ECS. This lack of $\mathrm{CoO}$ knowledge for some products in a category, when the $\mathrm{CoO}$ of other products is known, could compromise the conclusions reached in a comparative ECS.

A variety of potential approaches to identifying the $\mathrm{CoO}$ have been researched. Both expert knowledge from experienced FSD purchasers and a spectroscopic study of the component parts within an FSD, against an appropriate library, may help to reduce uncertainty with regard to identifying the $\mathrm{CoO}$ of a product as regards LCA input for a comparative ECS study.

It is evident that the LCA operative making a comparative ECS for FSD would require to at least have knowledge of testing based on functional specifications, material component analysis, material processing, origin knowledge and origin analysis, packaging technology, and LCA and FSD markets. The lack of relevant knowledge could lead to incorrect product choices in support of policy decisions. Incorrect assumptions can influence the relative position of a product within a comparative ECS of FSD.

The FUMCO method was tested and compared to the traditional methods of collection of product economic inventory.

It has been demonstrated that inaccuracy in product economic inventory data can substantially affect the calculated LCA rating for the products concerned.

Where like functionality products are to be ranked and rated based on the results of a comparative LCA, for which there is no stakeholder sourced product economic inventory data, it would appear that FUMCO can aid in improving the accuracy and objectivity of this data. FUMCO could aid in reducing the chance of low quality input, this being undesired, especially in a comparative study of products in which some products could be incorrectly ranked and rated.

The approach frequently adopted to test the sensitivity of the ranking exercise to particular aspects of product economic inventory data has been to select an individual target product from among a set of like functionality products, in order to test the sensitivity of the ranking and rating of that target product, due to inventory changes between a purely visual, or traditional, inspection of the product and a FUMCO approach. The inventory of the remaining products in the category were assumed to be unchanged in order to show the movement of that target product. Movement in the rating and ranking in response to changes in inventory data is just as likely to occur for all the other products in the category. This may lead to a further divergence in final rankings and ratings between a study based on a purely visual, or traditional, assessment of the product inventory and a study using the FUMCO approach. 
Studies ranging across the variety and diversity of FSD product categories demonstrate that most FSD could have visually unidentifiable product inventory which could otherwise be identified in a product economic inventory collection approach such as FUMCO.

While it has been established that FUMCO can contribute to increased objectivity in the study of comparative claims based on LCA studies in the absence of stakeholders, it is evident that subjectivity still plays a major role. This subjectivity is most apparent in establishing the FS desired to be represented within the category. Compliance to the FU and product functionality rules (PFR) can be objectively measured, but FS choices are subjective and would not appear to be objectively measurable.

The research further served to confirm the advantage of FUMCO in materials composition identification and the associated processing, compared to taking the traditional collection approach.

Regarding the $\mathrm{CoO}$ identification benefits of FUMCO, it is evident that the materials identification provides an initial benefit in $\mathrm{CoO}$ identification. Thereafter, expert witness and comparative spectroscopy further contribute to improve the reliability of CoO identification. It would appear important that expert knowledge and any comparative samples/spectra be maintained in an up to date reference source.

The lack of technologically relevant knowledge in LCA studies has been cited in various research papers. The research within this study can be seen to confirm this as both a valid and a significant critique. There are many points within the comparative study of FSD products that require technologically relevant knowledge as well as market/product knowledge. The lack of this knowledge can be seen to produce results that do not reflect the true position of a product within a comparative claim. The need for technologically relevant knowledge of FSD could be seen to be far more important if there is no product stakeholder providing reliable product economic inventory data.

It would appear that taking a visual, or traditional, inventory collection approach could misrepresent product ratings within a category, compared to studies taking a FUMCO approach alongside associated technical and product relevant knowledge. The choices in a traditional study are potentially more subjective, whereas the FUMCO approach brings more objectivity to the study.

Interviews with experts showed that they understand the presented issues. They identified possible limitations in a FUMCO approach but had no common critical opinion against its use. The experts saw the added value of the developed method but were hesitant, due to issues related to possible operational costs and the extent to which a laboratory approach can always identify all components. Specifically, they questioned the ability of FUMCO to identify the $\mathrm{CoO}$, given the complexity of product supply chains. 
Given that the collection of product economic inventory data can be relatively laborious and expensive to achieve, some LCA experts suggest that there is a place for a simpler and more superficial approach, giving a "helicopter view" approximate assessment of a product or category of products. Whilst there might possibly be a place for such preliminary studies, it must always be borne in mind that such studies can be unreliable, particularly as regards relative ranking of the LCA impacts of competing products available from the market. Of concern is that data from such studies could end up in future studies, as the experts referred to sourcing of inventory data from previous studies.

It was seen as helpful to provide LCA practitioners with a tool kit on how to proceed with life cycle product economic inventory collection in the absence of stakeholders, providing a structured approach to high quality product economic inventory data collection.

Forty-six findings of the research are listed in the conclusion of this study, as well as observations regarding the contributions and limitations of FUMCO. These findings and observations consider what has been learnt from the study and its contribution to product comparative ECS.

While experts agreed that there was value in taking a FUMCO approach to product economic inventory collection for LCA input, they did not see it as a "silver bullet" in solutioning the overall issues related to LCA. This study focused on product economic inventory collection, reflecting a concern sometimes pointed to as GIGO (i.e. "Garbage In, Garbage Out"). This research did not focus on LCA methodologies or common dataset $\mathrm{LCI}$ quality. Evident inventory errors are common in published product LCA. Thus, the main motivation driving this study was to establish a method to reduce these errors and allocate to products their correct economic inventory, regardless of the LCA methods used in any study.

The findings in this research contribute to a better understanding of product economic inventory data collection for input to LCA. Such data is required to be accurate but no formalized method of collection of this data is currently available. Current methods of product economic inventory collection, combined with a potential lack of product technologically relevant knowledge, does not always identify the correct inventory data. FUMCO is a proposed, more reliable method. It clearly demonstrates that differences can exist in inventory data, dependent on the collection method used. These differences influence the relative comparative ECS score or ranking of a product within a category.

It is hoped that this study will encourage further research into product economic inventory data collection for LCA input, which may in turn lead to a final agreed inventory collection methodology that all practitioners can benefit from. The current strict rules on inventory data accuracy are of little value unless guidelines are established, clearly identifying how sufficiently robust and accurate data can be obtained. Adherence to such guidelines should be strictly required in any valid study. 


\section{Samenvatting}

The following is a translation into Dutch of the Summary of the study. It is the English language version that should be considered the official version of the Summary.

Veel mensen kopen als ze onderweg zijn iets te eten of te drinken; vaak wordt dit meegegeven in een artikel voor eenmalig gebruik; zogenoemde food service disposables (FSD). Er wordt erkend dat deze activiteit een impact heeft op het milieu en er is veel interesse in het kwantificeren en minimaliseren van deze impacts. FSD-artikelen worden verhandeld in een erg competitieve internationale markt. De spelers in deze markt proberen een voorsprong te behalen op hun concurrenten doormiddel van claims op hun eigen producten. Wanneer er bijvoorbeeld gekeken wordt naar koffiebekers, dan worden er veel verschillende claims op de bekers gedrukt. Veel van deze claims hebben betrekking op het milieu, omdat wij leven in een periode met een vloedgolf aan milieuclaims.

Een veelgehoorde vraag is: "Welke van deze producten heeft de laagste milieu-impact?". Hoe deze vraag te beantwoorden is van belang. Producten met eenzelfde functionaliteit moeten vergeleken worden op basis van een milieuaspect om vervolgens gerangschikt te worden op basis van deze beoordeling, indien deze ook gekwantificeerd kan worden.

Op FSD kunnen allerlei verschillende soorten milieuclaims gevonden worden. FSD bieden een ideaal medium om de implicaties van het opstellen van een vergelijkende milieuclaim verklaring of environmental claim statement (ECS) in kaart te brengen. Van hun levenscyclus zou kunnen worden gezegd dat er geen specifieke gebruiksfase gerelateerde impact op het milieu wordt uitgeoefend, wat de levenscyclus input en output relatief eenvoudig houdt. De prevalentie en wereldwijde groei in het gebruik van FSD kan duiden op een groot verbruik van grondstoffen en is daarom waardevol om te bestuderen met betrekking tot ECS.

Er moet worden opgemerkt dat er veel verschillende milieu impact categorieën zijn, waaronder onder andere: de bijdrage aan atmosferische $\mathrm{CO}_{2}$-niveaus, uitputting van grondstoffen en milieuverontreiniging. Om een beoordeling te kunnen maken die nuttig is voor consumenten van FSD wordt algemeen overeengekomen dat deze uit een enkele waarde moet kunnen worden afgeleid, zoals een die gecommuniceerd kan worden via een ECS-rating. Dit omvat een overeengekomen methode voor het wegen en normaliseren van verschillende impact categorieën waardoor dit uiteindelijk in een enkele waarde kan worden weergegeven. Het model dat wordt gebruikt om dit te bereiken, ligt aan de kern van de gekozen beoordelingsmethode.

De meest relevante ECS-claims zijn degene die de relatieve milieu impact verschillen trachten vast te leggen tussen producten met eenzelfde functionaliteit. Om deze claims te kunnen formuleren, zoals beschreven staat in International Organization for Standardization (ISO) 14025 of de EU Product Environmental Footprint Category Rules (PEFCR), is het gebruik van Life Cycle Assessment (LCA) een vereiste en is het van belang 
om medewerking te zoeken bij de belanghebbenden om toegang te krijgen tot de product economische inventarisgegevens ter invoer in een LCA.

LCA wordt gezien als de juiste manier van kwantificeren, waardoor het mogelijk is om het product met de "laagste milieu-impact" te identificeren in bovenstaande vraag.

In deze studie worden de kwesties onderzocht die moeten worden meegenomen bij het ontwikkelen van een betrouwbaar vergelijkend ECS voor FSD, gekwantificeerd middels LCA. Onderzoek toont aan dat de product economische inventarisgegevens in gepubliceerde LCA-studies van FSD-producten vaak onjuist zijn. Deze studie toont de noodzaak aan om nauwkeurige inventarisgegevens te gebruiken, om zo de betrouwbaarheid van de uiteindelijke rangorde van producten binnen een vergelijkend ECS te waarborgen. Dit leidde tot de volgende centrale onderzoeksvraag:

\section{CRQ: Is het mogelijk om een methode te ontwikkelen om de kwaliteit van product economische LCA-inventarisgegevens te optimaliseren, ter ondersteuning van vergelijkende claims op basis van product LCA, met en zonder medewerking van belanghebbenden?}

De term "belanghebbenden" refereert aan de fabrikanten en leveranciers van de FSD die worden onderzocht, welke er profijt van hebben als hun producten een goede beoordeling krijgen.

Er is een literatuuronderzoek met betrekking tot ECS, FSD, LCA, vergelijkende ECS en huidige methoden voor het verzamelen van product economische inventarisgegevens uitgevoerd. Dit heeft aangetoond dat FSD regelmatig een ECS tonen en dat een dergelijke claim met context, een product vergelijkende claim, nuttig zou zijn, als deze claim idealiter gebaseerd is op een LCA. LCA gebaseerde claimmethoden zoals Product Environmental Footprint (PEF), Environmental Product Declaration (EPD) en verschillende relevante ISO-normen zijn beoordeeld. Een studie van de huidige methoden voor het verzamelen van product economische inventarisgegevens is uitgevoerd met behulp van een literatuurstudie en een vragenlijst die is afgenomen bij LCA-experts.

FSD zijn belangrijk vanwege hun hygiënische voordelen, gemak, commerciële waarde en benodigde hoeveelheid grondstof. FSD worden gemaakt door vele verschillende partijen, van een breed scala aan materialen en composieten waarbij veel conversieprocessen van toepassing zijn, zodat ze allen eenzelfde functionaliteit hebben. FSD-materialen zijn onder andere papier, karton, kunststoffen, composieten en hout met hun verschillende conversieprocessen, zoals spuitgegoten PS-bekers of een bedrukt karton met een extrusie coating welke is gesneden, gevormd en geseald tot de iconische papieren beker.

FSD zouden kunnen worden gedefinieerd als producten met een minimalistisch ontwerp voor een specifieke toepassing, waarbij de minimale hoeveelheid grondstoffen wordt 
gebruikt voor de eenmalige gebruiksfunctie van het onderweg (buiten de deur) consumeren van voedsel en dranken.

Onderzoek naar FSD heeft aangetoond dat er weinig wetenschappelijke bronnen zijn, met weinig economische marktoverzichten. De keten heeft de vorm van een zandloper, met veel producenten, veel minder importeurs en veel gebruikers die FSD leveren aan klanten in de foodservicemarkt.

FSD worden bekritiseerd in milieutermen vanwege hun wegwerpkarakter, en ze worden vaak geassocieerd met milieuclaims die vaak zinloos of misleidend lijken.

Een vergelijkende claim, zoals de EU-richtlijn 92/75/EC energie-etiketteringsregeling, wordt aangehaald als een contextuele relevantie die voor consumenten begrijpelijk is. Als zo'n vergelijkend ECS moet worden opgesteld voor het meten van de milieueffecten van FSD, kunnen er grote uitdagingen zijn vanwege de complexiteit van de keten en het brede scala aan materialen en productieprocessen. Ook is ter discussie gesteld of het mogelijk is om op rationeel niveau verschillende productcategorieën te selecteren ter vergelijking.

Zoals uit de aanzienlijke concurrentie in de sector kan worden geconcludeerd is het ook nog maar de vraag of er betrouwbare medewerking van de belanghebbenden kan worden verwacht in de FSD-sector. Zonder medewerking van deze spelers zou het wellicht moeilijk zijn om de product economische inventarisgegevens te identificeren welke nodig zijn in een LCA voor een vergelijkend ECS.

De vergaande en complexe kwesties waarmee dit onderzoek te maken heeft gehad komen uit een zeer competitieve sector met weinig vanzelfsprekende medewerking van belanghebbenden, waarbij veel aandacht wordt besteed aan de definitie van functionele specificaties, evenals aan een breed scala aan materialen, processen en productbronnen.

Een studie naar LCA heeft aangetoond dat of een LCA gemaakt wordt met of zonder medewerking van belanghebbenden, met of zonder specifieke data, de implicaties met betrekking tot de keuze van een impact assessment methode, allocatie, onzekerheden en LCIAdatasets overwogen moeten worden, omdat zij de relatieve resultaten kunnen beïnvloeden.

Er is onderzoek gedaan naar de regels omtrent het ontwerpen van een op LCA gebaseerd ECS, met name PEFCR, EPD en ISO 14025. Er is geconcludeerd dat PEFCR, EPD en ISO 14025 ongeveer dezelfde lijn volgen. De volgende drie aspecten kwamen als belangrijk naar voren met betrekking tot product economische inventarisgegevens ter input voor een LCA:

1. Definitie van de functionele eenheid - Functional Unit (FU)

2. Materiaalsamenstelling - Material Composition (MC) - en de bijbehorende conversieprocessen

3. Land van herkomst - Country of Origin (CoO) 
Inzicht in de keten en technologisch relevante kennis op het gebied van FSD zijn kritieke aspecten die ook moeten worden meegenomen.

Er is onderzoek gedaan naar de sourcing en verzameling van product economische inventarisgegevens die als invoer voor LCA gebruikt kunnen worden. Er wordt aangehaald dat er zeer weinig is geschreven over het uitvoeren van product economische inventarisgegevensverzameling voor opname in een LCA-studie. Dit onderzoek omvatte studies van wetenschappelijke artikelen, een e-mailvragenlijst voor LCA-experts, interviews met experts en een studie van de handleidingen van LCA-tools. In de meeste gevallen wordt er met betrekking tot deze bronnen van uitgegaan dat de LCA-medewerker al over de product economische inventarisgegevens beschikt, zonder de bron van de gegevens te vermelden, wat de geciteerde observatie bevestigd.

Uit onderzoek is gebleken dat het gebruik van soortgelijke product gepubliceerde LCA-studies, technische literatuur, patenten, productverkoopliteratuur en informatie die beschikbaar is via internet gemaakt kan worden om product economische inventarisgegevens te identificeren. Vragen werden gesteld over hoe nauwkeurig deze informatie zou zijn met betrekking tot het identificeren van economische inventaris gegevens voor een product dat in een puur visueel onderzoek wordt beschreven als monomateriaal, maar dat, na op instrumentatie gebaseerde analyse, een composietmateriaal bleek te zijn bestaande uit een reeks componenten.

Bij het vergelijken van een categorie met FSD-artikelen die op het eerste gezicht allemaal van hetzelfde materiaal zijn gemaakt, kan het zijn dat de bovengenoemde benaderingen voor het verzamelen van product economische inventarisgegevens via belanghebbenden niet haalbaar is. Dit omdat FSD-producten van samengestelde materialen gemaakt kunnen zijn en ze niet identificeerbaar zijn in een puur visuele, of traditionele studie.

Om de impact van verschillende benaderingen op het verzamelen van product economische inventarisgegeven te begrijpen, is een scoremethode vereist waarmee de verschillende geteste kwesties kunnen worden beoordeeld. Er wordt vervolgens een vergelijking gemaakt tussen een categorie FSD-producten met dezelfde functionaliteit, waarbij een "uitgangsproduct" in de categorie wordt beoordeeld op de bijbehorende inventarisgegevens. Eerst met behulp van de traditionele methode voor gegevensverzameling van product economische inventarisgegevens en vervolgens met behulp van een voorgestelde gedetailleerde verzamelingsmethode, waarnaar wordt verwezen als FUMCO (een acroniem voor Functional Unit Material Composition Origin). De verandering in de relatieve scoringspositie van het uitgangsproduct als gevolg van een wijziging van traditioneel naar FUMCO-inventarisgegevens verzameling werd vervolgens geïdentificeerd.

Deze verschillen werden bestudeerd met betrekking tot product economische inventarisgegevens voor een verzameling aan producten die werden beoordeeld op 
hun soortgelijke functionaliteit, hun materiaalsamenstelling, hun conversieprocessen en hun land van herkomst. Literatuur verwijst naar het bestaan van een gebrek aan technologisch relevante kennis bij LCA-medewerkers als een punt van zorg. Voorbeelden van inventarisfouten in gepubliceerde LCA's werden bestudeerd en hun effecten werden geïdentificeerd.

Er is een scoremethode geïntroduceerd waarmee de verschillende te testen kwesties kunnen worden beoordeeld, waarbij de voorgestelde methoden nodig zijn om de implicaties van de systemen voor het verzamelen van product economische gegevens voor vergelijkende claimdoeleinden te volgen, testen en onderzoeken zonder de input en medewerking van belanghebbenden. Het is simpelweg een methode om het effect aan te tonen van veranderingen in de manier waarop product economische inventarisgegevens worden afgeleid.

Zoals hierboven opgemerkt, moet een algemene numerieke milieu-evaluatie worden afgeleid via de gekozen LCA-methode. In dit werk als geheel werd de ReCiPe-methodologie gebruikt, wat leidt tot een "eindpunt" numerieke waarde-indicator, welke vervolgens als basis dient voor een vergelijkende rating voor de producten binnen een bepaald onderzoek.

ReCiPe is een methode die gebruikt wordt voor de impactbeoordeling in LCA; het wordt gezien als eigentijds, het wordt veel gebruikt en is algemeen erkend. Het primaire doel van de ReCiPe-methode is het omzetten van lijsten met resultaten van de levenscyclusinventarisatie in een beperkt aantal indicatorscores. Deze indicatorscores geven de relatieve ernst weer van een milieueffectcategorie.

Er werd ook een beperkte studie uitgevoerd om duidelijkheid te scheppen over de gevolgen wanneer alternatieve methodes voor ReCiPe worden gebruikt. Weging en normalisatie van impactbeoordelingen en het bepalen van de bandbreedte zal een effect hebben op de relatieve positie van een item binnen een vergelijkend onderzoek. Hiermee moet rekening worden gehouden bij het kiezen van de methode en aanpak bij het ontwikkelen van een op vergelijking gebaseerde claim. Deze alternatieven hadden in het algemeen de neiging om vergelijkbare resultaten te produceren als bij ReCiPe met betrekking tot rangorde en rating bij veranderingen in de input van product economische inventarisgegevens.

De mate waarin een productcategorie moet worden gedefinieerd voor een vergelijkend ECS, gemaakt zonder de medewerking van de belanghebbende van het product, lijkt veeleisend te zijn om als objectief en geloofwaardig te worden beschouwd. ISO 14025:2006 stelt dat "de functie, technische prestaties en het gebruik van vergelijkbare producten identiek moeten zijn".

De behoefte aan testen of analyses om de soortgelijke functionaliteit vast te stellen wordt geïntroduceerd op basis van een Functionele Specificatie (FS) in afwezigheid van de belanghebbende bij het product. De exacte FS van het product moet worden gedefinieerd, 
en de kwalificatie voor opname in de categorie vereist mogelijk uitgebreide testen. Deze testen kunnen worden gezien als een objectieve beoordeling van de naleving van een subjectieve FU.

Veranderingen in de definitie van de categorie of productspecificatie of functionaliteit bleken tot verschillende resultaten te leiden wat betreft de positionering van producten binnen een vergelijkend ECS.

Product economische inventarisatie, inclusief identificatie van materialen binnen een component, is vereist om de juiste kwalitatieve en kwantitatieve materiaal input te leveren voor de LCA die gebruikt wordt om een vergelijkend ECS te formuleren. Materiaalanalyse draagt ook bij aan de identificatie van het conversieproces en heeft implicaties voor de verantwoording van transport en end-of-life scenario's.

Dit onderzoek toont het belang aan van een zo volledig mogelijke analyse. De verschillende effecten van de additieven, zoals calciumcarbonaat $\left(\mathrm{CaCO}_{3}\right)$ en titaniumdioxide $\left(\mathrm{TiO}_{2}\right)$ vulstoffen in kunststoffen, zijn aanzienlijk, waardoor ze niet genegeerd kunnen worden. Wanneer er een verschil in uitkomst is, dan is de enige juiste manier van handelen het toepassen van de meest grondige analyse die beschikbaar is. Een minder grondige aanpak kan in diskrediet worden gebracht.

Alternatieve analysemethoden voor materiaalanalyse zijn essentieel in een LCA-onderzoek, omdat materiaalgegevens vaak niet beschikbaar zijn of afkomstig zijn van onbetrouwbare bronnen. Het is duidelijk dat een eenvoudige visuele aanpak van materiaalidentificatie, soms de traditionele aanpak genoemd, essentiële materialen en processen in de productlevenscyclus over het hoofd kan zien.

Onderzoek toont aan dat de analyse van materialen met gebruik van analytische laboratorium instrumenten bijdraagt aan de potentiële nauwkeurigheid van een vergelijkend ECS. Ook laat het zien dat dit type analyse tijds efficiënt is, maar wel hogere initiële kosten heeft voor de exploitant vanwege de benodigde instrumenten.

Wanneer de CoO van een FSD onbekend is blijkt dit gevolgen te hebben voor de relatieve positie van het item binnen een vergelijkend ECS. Het gebrek aan CoO-kennis voor sommige producten binnen een categorie wanneer de $\mathrm{CoO}$ bij andere producten wel bekend is kan de conclusies in een vergelijkend ECS in gevaar brengen.

Verschillende benaderingen om de $\mathrm{CoO}$ te identificeren zijn onderzocht. Zowel kennis van FSD-inkopers als een spectroscopisch onderzoek van de verschillende component onderdelen binnen een FSD, in vergelijking tot een relevante bibliotheek, kunnen de onzekerheid verminderen met betrekking tot het identificeren van de $\mathrm{CoO}$ van een product wat betreft de LCA-input voor een vergelijkende ECS-studie. 
Het is duidelijk dat de LCA-medewerker die een vergelijkende ECS voor FSD maakt op zijn minst kennis moet hebben van: testen gebaseerd op functionele specificaties; materiaalcomponentenanalyse; materiaalverwerking; herkomst en herkomstanalyse; verpakkingstechnologie en de LCA- en FSD-markt. Het ontbreken van relevante kennis kan leiden tot verkeerde productkeuzes ter ondersteuning van beleidsbeslissingen. Onjuiste aannames kunnen de relatieve positie van een product binnen een vergelijkend ECS voor FSD beïnvloeden.

De FUMCO-methode is getest en vergeleken met de traditionele methoden die gebruikt worden voor het vergaren van product economische inventarisgegevens.

Er is aangetoond dat onnauwkeurigheden in de product economische inventarisgegevens de berekende LCA-rating bij desbetreffende producten sterk kan beïnvloeden.

Waar producten met eenzelfde functie moeten worden gerangschikt en beoordeeld op basis van de resultaten van een vergelijkende LCA, zonder input en medewerking van belanghebbenden voor de inventarisgegevens, lijkt het erop dat FUMCO kan helpen bij het verbeteren van de nauwkeurigheid en objectiviteit van deze data. FUMCO kan helpen bij het verkleinen van de kans op input van lage kwaliteit, wat ongewenst is, vooral in een vergelijkende studie waarin sommige producten onjuist kunnen zijn gerangschikt en beoordeeld.

De aanpak die vaak is gebruikt om de gevoeligheid van de rangorde voor specifieke aspecten van product economische inventarisgegevens te testen was het selecteren van een individueel uitgangsproduct uit een reeks producten met eenzelfde functionaliteit, waar veranderingen werden aangebracht in inventaris in een puur visuele of traditionele inspectie van het product en een FUMCO-benadering, om zo de gevoeligheid van de rangorde en rating van het uitgangsproduct te testen. De inventaris van de resterende producten in de categorie werd onveranderd gelaten om zo de beweging van het uitgangsproduct te laten zien. Beweging in de rating en rangorde door veranderingen in de inventarisgegevens zijn net zo waarschijnlijk bij de andere producten in de categorie. Dit kan leiden tot een verdere afwijking in de uiteindelijke ranglijsten en beoordelingen tussen een studie die puur op visueel of traditionele beoordeling is gericht en een studie volgens de FUMCO-benadering.

Studies gedaan door een verscheidenheid en diversiteit aan FSD-productcategorieën laten zien dat de meeste FSD visueel niet-identificeerbare inventarisgegevens kunnen hebben, die wel geïdentificeerd zouden kunnen worden in een product economische inventarisverzamelingsbenadering zoals FUMCO.

Hoewel is vastgesteld dat FUMCO kan bijdragen aan een verhoogde objectiviteit in de studie van vergelijkende claims op basis van LCA-onderzoeken zonder medewerking van belanghebbenden, is het duidelijk dat subjectiviteit nog steeds een grote rol speelt. 
Deze subjectiviteit is het meest zichtbaar bij het vaststellen van de verschillende FS die binnen de categorie gerepresenteerd worden. Naleving van de FU en productfunctionaliteitsregels (PFR) kan objectief gemeten worden, maar keuzes voor FS zijn subjectief en zijn niet objectief meetbaar.

Het onderzoek diende verder om het voordeel van FUMCO te bevestigen in de identificatie van de materiaalsamenstelling en de daarbij behorende verwerkingsprocessen, in vergelijking met de traditionele gegevens verzamelbenadering.

Wat betreft de voordelen van de CoO-identificatie van FUMCO is het duidelijk dat de materiaalidentificatie een eerste voordeel biedt voor deze CoO-identificatie. Daarnaast dragen experts en spectroscopie verder bij aan het verbeteren van de betrouwbaarheid van $\mathrm{CoO}$-identificatie. Het blijkt belangrijk dat kennis van deskundigen en eventuele vergelijkende monsters en spectra up-to-date worden gehouden in een referentiebron.

Het gebrek aan technologisch relevante kennis in LCA-studies is in verschillende onderzoeksrapporten aangehaald. Het onderzoek gedaan in deze studie bevestigd dit en laat de significantie ervan zien. Er zijn veel punten in de vergelijkende studie van FSDproducten die technologisch relevante kennis en markt-/productkennis vereisen. Het ontbreken van deze kennis kan resultaten opleveren die niet de juiste positie van een product laten zien in een vergelijkende claim. De behoefte aan technologisch relevante kennis van FSD kan als veel belangrijker worden beschouwd als er geen medewerking van de belanghebbende is, die betrouwbare product economische inventarisgegevens kan verstrekken.

Het blijkt dat door een visuele of traditionele benadering van een inventarisverzameling productbeoordelingen binnen een categorie verkeerd zouden kunnen worden weergeven in vergelijking met studies die een FUMCO-benadering volgen naast bijbehorende technische en productrelevante kennis. De keuzes in een traditioneel onderzoek zijn potentieel subjectiever, waar de FUMCO-benadering het onderzoek juist objectiever maakt.

Uit interviews met experts is gebleken dat zij de gepresenteerde problemen begrijpen. Ze identificeerden mogelijke beperkingen in een FUMCO-aanpak, maar hadden geen gemeenschappelijke kritische mening tegen het gebruik ervan. De experts zagen de toegevoegde waarde van de ontwikkelde methode maar aarzelden vanwege problemen in verband met mogelijke operationele kosten en de mate waarin een laboratoriumbenadering altijd alle componenten kan identificeren. In het bijzonder trokken zij het vermogen van FUMCO om de $\mathrm{CoO}$ te identificeren in twijfel, gezien de complexiteit van productieketens.

Aangezien het verzamelen van product economische inventarisgegevens relatief arbeidsintensief en duur kan zijn, suggereren sommige LCA-experts dat er plaats is voor een makkelijkere en meer oppervlakkige aanpak. Bij deze aanpak wordt vanuit een 
"helikopterview" een benaderende beoordeling gegeven op een product of categorie. Hoewel er mogelijk plaats is voor dit soort studies, moet er altijd rekening mee gehouden worden dat dergelijke studies onbetrouwbaar kunnen zijn, met name wat betreft de relatieve rangschikking van de LCA-impacts van concurrerende producten die op de markt verkrijgbaar zijn. Zorgwekkend is dat gegevens uit dergelijke studies in toekomstige studies terecht zouden kunnen komen, aangezien de experts bij het sourcen van inventarisgegevens naar eerdere studies verwezen.

Het wordt als nuttig gezien om LCA-beoefenaars een toolkit te bieden over hoe zij verder kunnen gaan met het vergaren van product economische inventarisgegevens zonder de medewerking van belanghebbenden. De toolkit biedt een gestructureerde aanpak voor het verzamelen van hoogwaardige product economische inventarisgegevens.

46 bevindingen van het onderzoek worden vermeld in de conclusie van dit onderzoek, evenals observaties met betrekking tot de bijdragen en beperkingen van FUMCO. Deze bevindingen en observaties houden rekening met wat er is geleerd uit de studie en de bijdrage ervan aan product vergelijkende ECS.

Hoewel experts het erover eens waren dat het nuttig was om een FUMCO-benadering te gebruiken voor het verzamelen van product economische inventarisgegevens voor LCAinput, zagen ze het niet als een vereiste bij het oplossen van de algemene problemen met betrekking tot LCA. Deze studie was gericht op het verzamelen van product-economische inventarisgegevens, komende uit een zorg die soms wordt aangeduid als GIGO (d.w.z. "Garbage In, Garbage Out" ofwel "Rotzooi erin, Rotzooi eruit"). Tijdens dit onderzoek lag de focus niet op LCA-methodologieën of algemene LCl-kwaliteit van de dataset. Duidelijke inventarisfouten komen veel voor in gepubliceerde product-LCA's. De belangrijkste motivatie voor deze studie was een methode te ontwikkelen die deze fouten vermindert en de juiste economische inventarisgegevens aanvoert voor producten, ongeacht welke LCA-methode gebruikt wordt in welke studie dan ook.

De bevindingen in dit onderzoek dragen bij aan een beter begrip van het verzamelen van product economische inventarisgegevens voor input in LCA. Dergelijke gegevens moeten nauwkeurig zijn, maar er is momenteel geen geformaliseerde methode beschikbaar voor het verzamelen van deze gegevens. Huidige methoden voor het verzamelen van product economische inventarisgegevens, gecombineerd met het potentiële gebrek aan technologisch relevante productkennis, zorgt niet altijd voor de juiste inventarisgegevens. FUMCO is een voorgestelde, meer betrouwbare methode. Het toont duidelijk aan dat er verschillen kunnen bestaan in inventarisgegevens, afhankelijk van de gebruikte verzamelmethode. Deze verschillen beïnvloeden de relatieve vergelijkende ECS-score of rangorde van een product binnen een categorie.

Er wordt gehoopt dat deze studie verder onderzoek naar product economische inventarisgegevensverzameling voor LCA-input aanmoedigt, wat op zijn beurt kan leiden 
tot een definitieve overeengekomen methode voor inventarisverzameling waarvan alle beoefenaars kunnen profiteren. De huidige strikte regels voor de nauwkeurigheid van inventarisgegevens zijn van weinig waarde, tenzij er richtlijnen worden opgesteld die duidelijk aangeven hoe voldoende robuuste en nauwkeurige gegevens kunnen worden verkregen. Naleving van dergelijke richtlijnen zou een strikte vereiste moeten zijn in iedere geldige studie. 


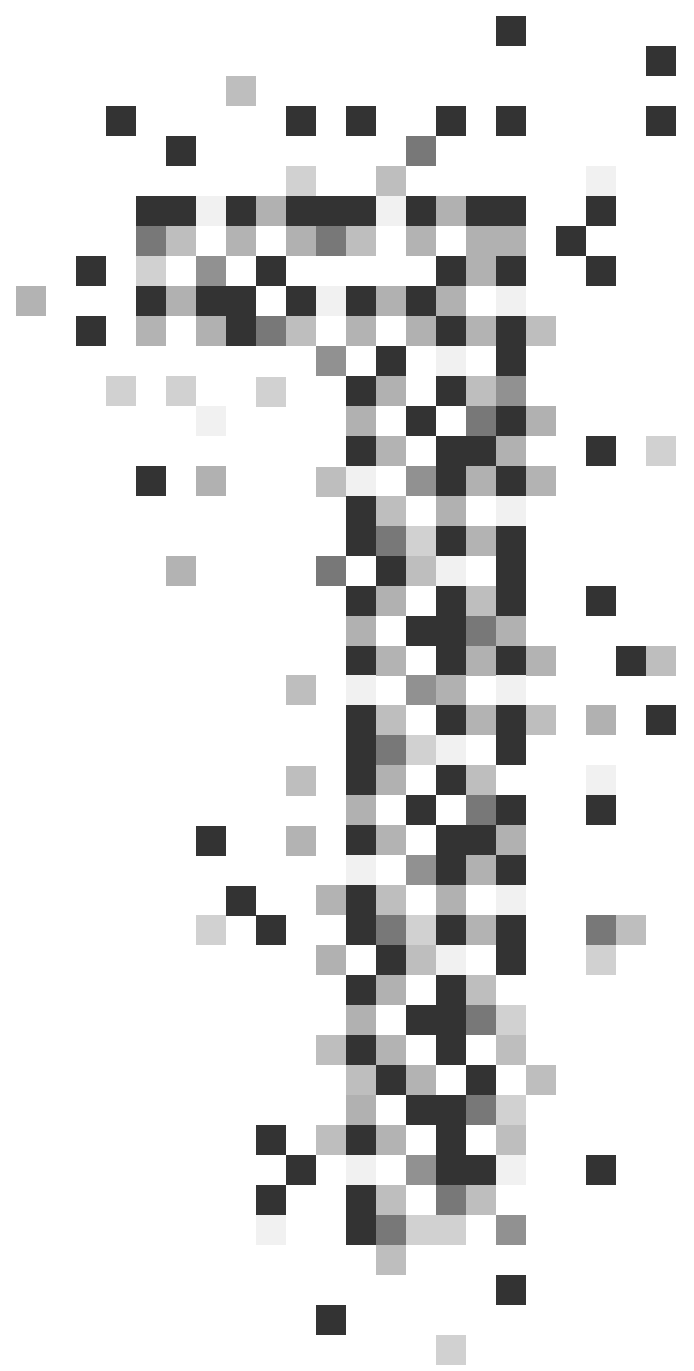




\section{PART 1}

\section{Chapter 1}

\section{Introduction to the study}




\subsection{Introduction}

Many people buy food and drinks while on the move that are mostly provided in single use articles, so-called food service disposables (FSD). It is notable that when looking at coffee cups, for example, claims can be found that are printed across a wide range of different cups. Many claims refer to sustainability. The reason is obviously marketing, but the reason behind this could be the reassurance that having coffee in a disposable does not harm the environment or at least the buyer should not feel guilty about the fact that the article is thrown away after a single use.

It is an interesting development that environmental claim statements (ECS) are taken up on disposables and not typically on durables with a similar function, like a ceramic coffee mug or a porcelain plate. For products that use energy or fuel, the energy use is often a key figure in the sales argument. For electrical equipment, this is presented at the point of sale by a table with coloured bars going from red to green. For cars, the number of kilometres per litre of fuel is a key figure that is being used as a sales argument and has even been rewarded with lower taxes by the Dutch government.

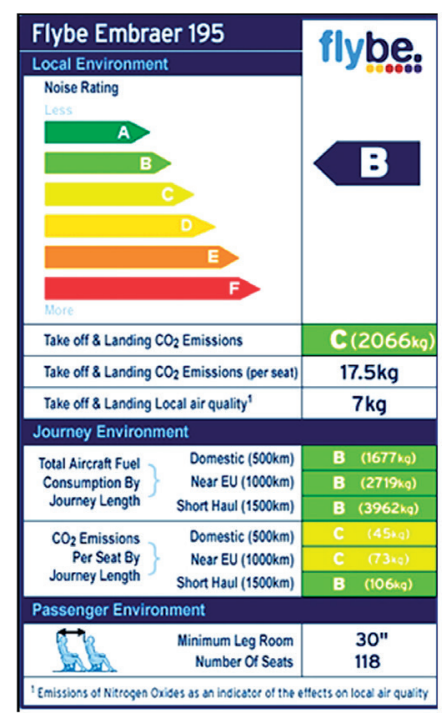

Figure 1.1: An Environmental Claim as Displayed on the Side of an Aircraft

FSD are generally very thin, light weight items that are used for the consumption of food and beverage products 'on the move', as it is being called in marketing terminology. The materials used to produce these items do not seem to differ much. Plates, trays, cups are often produced from carton board or plastics. There are many differences between the items as they are available in various thicknesses and have varying capacities. Take, for example, the volume of a cup which ranges from $50 \mathrm{ml}$ to over one litre. Regarding FSD, 
there does not seem to be a clear way of comparing the articles with each other. Even if there are claims on the different types of cups, it is not immediately clear if a plastic cup is less harmful for the environment than a coated carton cup, to use an example of the two most common types of coffee cups.

Nevertheless, it is an interesting question, not only to understand the environmental load of FSD and to seek to understand if it is possible to find a way to compare FSD with each other, but also if it is possible to find a way to present this, for example printed on a cup. This could possibly help to get insight into judging the environmental load of other groups of articles, like a related category such as packaging. For packaging, the chain from raw material to disposal has more steps than the chain of FSD. Aspects like spoilage of the packed product before use, the method of use, leftovers in the pack, to mention but a few, influence the environmental load of a packed product. This is not the case for FSD. Research into FSD could therefore also help to get insight into other related products.

This era has seen the introduction of the UN Sustainable Development Goals, The EU Circular Economy Package and the COP21 Climate Change Conference in Paris, all seeking to address the health of the planet. The use of articles that are thrown away after one time use does raise questions from this viewpoint. It would seem to be in conflict with the efforts being made to address the health of the planet. Getting insight into FSD and their market size, functionality, component materials, life cycle impact, to mention but a few aspects, leading to a comparison concerning sustainability could help in reaching the goals of a healthier planet. If this is possible, parties like NGOs, businesses, as well as policy makers can try to influence sales in favour of the less polluting FSD or accelerate innovation in this business area.

\subsection{Environmental Claim Statements}

Consumer consumption choices play a major role in the health of the planet. Hence, we live in a period in which there is a "virtual tsunami of environmental marketing" (Minneti, J., 2010, p. 655). Environmental Claim Statements (ECS) are regularly seen as labels or comments attached to products or their packaging.

EU guidelines (Guidelines for Making and Assessing Environmental Claims; EC DirectorateGeneral Health \& Consumer Protection; December 2000) define environmental claims as a "Statement, symbol or graphic that indicates an environmental aspect of a product, a component, packaging or a service".

Many similar products can be seen with a range of different labels, such as ISO 14001, EMAS, European Flower, Energy Star, ISO 26000, and Fairtrade (Nikolaou, I. E., et al., 2018). 
According to Morris (Morris, J., 1997), the driver for making environmental claim statements is the differentiation of a product from other competing products, to encourage the consumer to purchase a specific item because they feel more responsible and probably less guilty by buying an item which is perceived as being more environmentally responsible. In Magnier, L. (Magnier, L., et al., 2017), it is cited that an environmental claim regarding a package can positively influence the perception of the environmental friendliness of a package, even when it is not issued by a third-party organization.

Eco labels have been cited as positively influencing the market share of a product displaying an environmental claim statement (Teisl, M., 2002). Markandya (1997) and Zarrilli et al. (1997) identifies parties gaining competitive advantage from the adoption of environmental labelling. The widespread use of ECS would suggest that they are perceived as an effective method of altering consumer behaviour (Teisl, M., 2002). Environmental labelling is cited as not just improving the sales of a company but also its image (Galarraga Gallastegui, l., 2002).

As a tool for marketing, the ECS guides consumers to make environmentally aware choices, hence ECS is a vehicle to promote their products from an environmental perspective (Schmincke et al., 2001). It could also be said that ECS and eco-labels serve to awaken consumers to the fact that environmental impact applies to all products or consumption of goods (Galarraga Gallastegui, I., 2002) and not just those using energy or producing emissions during their use. In addition, they serve to awaken them to the field of embodied impacts, which may not necessarily have been evident to them, and inform them that what they buy matters (Teisl, M., 2008). The most informative of ECS might be those that seek to establish the relative environmental impact difference between items of like functionality (Horne, R. E., 2009) (Larson, J., et al., 2011) (Ingwersen, W.W., et al., 2012).

In Zackrisson. M., et al. (2008), the lack of reliable claims is stated as being an important barrier to the design and selling of items of improved environmental performance. The fact that claims might not be seen as reliable by consumers delays the acceptance of better solutions; an interesting viewpoint by Zackrisson et al.

Despite all the research, it can be questioned if all ECS on FSD are being read, understood and believed by users on a large scale looking at some of the claims, like "100\% sustainable". Many people probably will think that marketing is the main purpose after reading such a claim.

It could be stated that ECS play a role in influencing customers' choice and therefore act to aid the promotion of the products of the claimer. Hence it would seem appropriate to attempt to understand the choices and methodology involved in ECS in order to maximize the quality of the advice they provide to the consumer.

The question is, can a claim like ' $100 \%$ sustainable' be made according to Directive 2005/29/EC regarding the use of claims? This directive states that a trader is required 
"to produce evidence as to the accuracy of factual claims they have made", which would suggest that ECS would have to be accurate. The International Chamber of Commerce website states that "General environmental claims that may prove difficult to substantiate using accepted scientific methods should be avoided"; Article 1 stating that "All marketing communication should be legal, decent, honest, and truthful".

In the United States and the United Kingdom, the wording of claims is subject to strict and understood guidelines (Morris. J., 1997) (Minneti, J., 2010).

Nutrition labelling on food, showing quantitative data, is only compulsory if a nutrition claim, such as 'low salt' or 'high in vitamin $C^{\prime}$ ', is made on the label. When nutrition information is placed on a label, it must adhere to the rules set out in the nutrition labelling legislation (Regulation (EU) No 1169/2011 - food information to consumers). In the case where a food claim is made, it also has to be quantitatively substantiated. It could be asked if it would be possible to set the same requirements for environmental claims. Quantitative ECS are often referred to as nutritional labels with environmental information (Ingwersen, W.W., et al., 2012).

For comparative based claims to be applicable within a product category, the EU Product Environmental Footprint (PEF) requires common rules. These product category rules (PCR), as defined in the ISO 14025 standard (and in EN 15804), define how life cycle environmental impacts should be developed for products within a given category. This standardized way of quantifying the environmental impact of a product or system can be used and therefore must be analysed.

The ISO standards 14024, 14021 and 14025 define three types of environmental claims. Descriptions of the type of claims are taken up in the Table 1.1 below:

Table 1.1: Environmental Claim Types as Defined by ISO Standards

\begin{tabular}{l|l|l}
\hline \multirow{4}{*}{ TYPE I } & $\begin{array}{l}\text { a voluntary, multiple-criteria based, third party program that awards a license } \\
\text { that authorizes the use of environmental labels on products indicating } \\
\text { overall environmental preferability of a product within a particular product } \\
\text { category based on life cycle considerations }\end{array}$ & $\begin{array}{l}\text { ISO (Standard } \\
\mathbf{1 4 0 2 4 : 1 9 9 9 )}\end{array}$ \\
\hline \multirow{3}{*}{ TYPE II } & $\begin{array}{l}\text { self-declared environmental claims that are made, without independent third } \\
\text { party certification, by manufacturers, importers, distributors, retailers or } \\
\text { anyone else likely to benefit from such a claim }\end{array}$ & $\begin{array}{l}\text { ISO (Standard } \\
\mathbf{1 4 0 2 1 : 1 9 9 9 )}\end{array}$ \\
\hline \multirow{2}{*}{$\mathbf{T Y P E}$ III } & $\begin{array}{l}\text { voluntary programs that provide quantified environmental data of a product, } \\
\text { under pre-set categories of parameters set by a qualified third party and based } \\
\text { on life cycle assessment, and verified by that or another qualified third party }\end{array}$ & $\begin{array}{l}\text { ISO (Standard } \\
\mathbf{1 4 0 2 5 : 2 0 0 6 )}\end{array}$ \\
\hline
\end{tabular}

Approaches to these claims require life cycle considerations for Type I claims or the use of Life Cycle Assessment (LCA) for Type III claims. Type III claims are based on the most complete analysis of the chain and therefore can be seen as coming closest to the wish of the International Chamber of Commerce: be legal, decent, honest, and truthful and to Directive 2005/29/EC. Although the Life Cycle Assessment tool is a well-known and often studied tool, some attention will be paid to it. 
Reference is also made to LCA as regards packaging and FSD in the following recent EU instruments:

1. The Packaging and Packaging Waste Directive (https://eur-lex.europa.eu/legalcontent/EN/TXT/PDF/?uri=CELEX:01994L0062-20150526\&from=EN).

2. The Green Public Procurement (http://ec.europa.eu/environment/gpp/index_en.htm)

3. The Plastics Strategy (http://ec.europa.eu/environment/circular-economy/pdf/ plastics-strategy.pdf).

4. EU Single-Use Plastics (http://ec.europa.eu/environment/circular-economy/pdf/ single-use_plastics_proposal.pdf).

\subsection{The Use of Life Cycle Assessment}

Many sources require the use of Life Cycle Assessment (LCA) in the approach to developing environmental claims. Examples include:

1. ISO 14025 (ISO 14025:2006)

2. EU Product Environmental Footprint Category Rules (PEFCR)

3. Environmental Product Declarations (EPD)

4. Environmental Life-Cycle Rating Labels (ELCRL) (Larson, J., et al., 2011)

LCA is a tool that quantifies environmental stressors, such as resource use and emissions, that occur over the life cycle of anthropogenic systems and translate these stressors into metrics of environmental interferences for a number of mutually exclusive and collectively exhaustive "impact categories", such as climate change, eutrophication, and eco-toxicity (Bjorn, A., et al., 2015, p. vii).

The nature of a comparative claim is that it identifies differences between items, quantity of material per functional unit (such as drinking 1 hectolitre of coffee), companies, business sectors, countries, to mention but some, and as such would require to be as complete as possible.

This associated inventory input data for an LCA is derived from category rule choices, individual product studies and a variety of potentially missing information or variable choices. The variety of potentially missing information must be researched for a good LCA, such as the number of times a durable cup is used, the average amount of water used for its washing, being dependent on how it is washed, by hand or machine, the type of machine etc. (VROM 1991, Reusable or Disposable). Outcomes will have tolerances as can be understood.

Understanding the challenges associated with achieving a viable LCA inventory input preparation method, in correlation with the existing input variability of LCA and in respect to identifying the product alternative with the lowest environmental burden, would potentially be of interest to research in order to get insight into this topic. 
Paragraph 6 of the Commission Recommendation of 9th April 2013 on the use of common methods to measure and communicate the life cycle environmental performance of products and organizations states:

The Communication on "A European Consumer Agenda - Boosting confidence and growth" stressed that consumers have the right to know the environmental impacts throughout the life cycle of the products they intend to buy and they should be supported in easily identifying the truly sustainable choice. It stated that the Commission will develop harmonised methodologies to assess the life cycle environmental performance of products and companies as a basis for providing reliable information to consumers.

This recommendation can usefully underpin a harmonized approach to developing a comparative ECS. Page 1 of the Executive Summary of the Product Environmental Footprint (PEF) Guide dated 04/05/2013 states:

This PEF Guide has been developed in the context of one of the building blocks of the Flagship initiative of the Europe 2020 Strategy - "A Resource-Efficient Europe" (2). The European Commission's "Roadmap to a Resource Efficient Europe" (3) proposes ways to increase resource productivity and to decouple economic growth from both resource use and environmental impacts, taking a life-cycle perspective. One of its objectives is to: "Establish a common methodological approach to enable Member States and the private sector to assess, display and benchmark the environmental performance of products, services and companies based on a comprehensive assessment of environmental impacts over the life-cycle ('environmental footprint')".

Hence it could be said that PEF would be an ideal vehicle for addressing the question - is it possible to develop a method to make reliable ECS, notably comparative ECS? However, the above Guide specifically states (p. 2) that it is not intended to support comparative claims but states that "Such comparisons require the development of additional PEFCR that would complement the more general guidance given here, in order to further increase methodological harmonisation, specificity, relevance and reproducibility for a given product-type."

While PEF is the development of the methodology, PEFCR incorporates additional requirements in order to make a Type III claim. PEF applications are defined (p. 6) as supporting external B2B or B2C environmental claims and labels, specifically defining an average performing product based on generic data or approximation (p. 7) "followed by a grading of other products according to their performance" versus a benchmarked product. 
Page 10 of the Guide states:

"The relevant PEFCR document may be used to support the comparison of the environmental performance of products from the same product category on a lifecycle basis, as well as to support comparative assertions (intended to be disclosed to the public). Therefore, comparability of the results is crucial. The information provided for this comparison shall be transparent in order to allow the user to understand the limitations of comparability inherent in the calculated result (adapted from ISO 14025)."

In accordance with PEFCR, the research has to understand the nature and value of the inventory input data to the LCA.

While there is a significant body of knowledge regarding LCA, it would appear that there is less study of the challenges and implications of establishing the product economic inventory input to LCA (Baumann, H., et al., 2004) with regard to their use for comparative claims. Academic papers cite the need for accurate input to LCA, for example Ayres, R.U., 1995, but do not seek to describe an approach to developing such input. For a type III claim, PEFCR asks for generic data or approximation as input. Many disposables like coffee cups from carton board are polymer coated. Many plastics are coloured white with additives. This raises questions about the accurateness of an LCA if it were based on visible materials identification and generic LCIA datasets.

To obtain understanding from FSD, especially the differences between them from the viewpoint of sustainability, more research must be carried out. To understand the differences between FSD, the functionality is the first issue to research; is there a difference in items and how could they be compared?

If comparisons are to be fair and FSDs are designed for their functionality, it would appear that defining the functionality and then identifying that like functionality across the articles would be required in order to establish the rules associated with a specific FSD comparison. A small fork to eat French fries is not the same as a fork to eat salad. There are differences between the forks: the material, the weight, probably the strength which dictates how much food it can hold, the temperature resistance etc. If comparable items can be found, or a method to distinguish them, the next question is - can they be compared as regards environmental load? 
The study therefore will seek to address two phases of the type of question exemplified in Figure 1.2 below, with a disposable fork as example, notably:

1. Categorization Phase

2. Quantification Phase

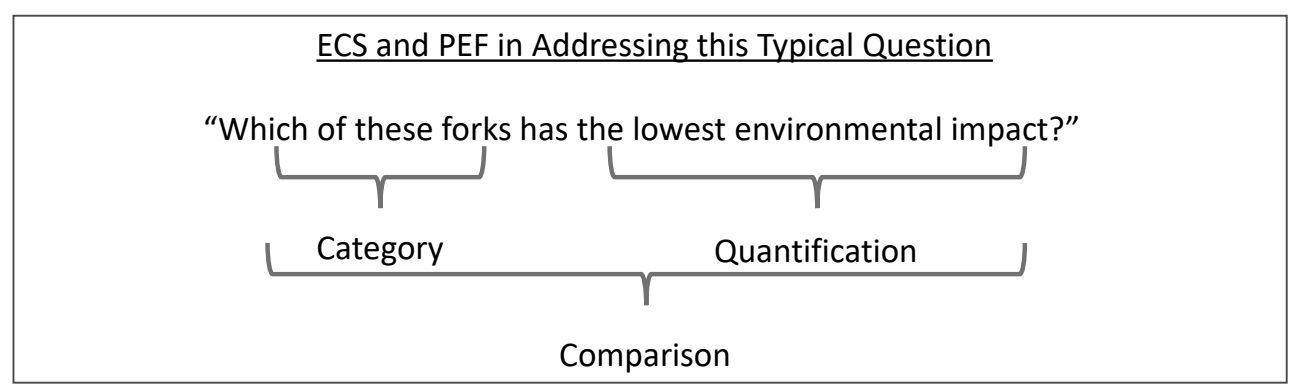

Figure 1.2: The Two Phases of Categorization and Quantification

It is necessary to understand how choices related to the above influence the final outcome of any associated sustainability study and the related outcome to comparative ECS, ecolabel with context, or PEF.

The study will also address the important issue that any proposed model approach needs to take account of and how readily it could be applied by organizations aiming to develop relevant PEF or ECS. As EU Commissioner Vela has declared: "our motto is, if it can't work for SME it can't work for anyone" (Mid-Term Conference on the Environmental Footprint Pilot Phase - Brussels, 3-4 November 2015). That seems appropriate guidance. 


\subsection{Food Service Disposables (FSD) as the Product Choice for this Study}

In Ju, S et al., 2015, a study was made as to the sustainable actions in food service that derive the greatest appreciation from customers. The highest rated of these related to FSD choice. Green packaging in food service operations had a strong relationship with the image of the organization (Ju, S., \& Chang, H., 2014).

Environmental claims of various questionable types are commonly found on FSD. FSD could provide an ideal medium for understanding the implications of establishing a Type III label. Their life cycle could be said to have no specific use-phase charge on the environment, hence limiting their life cycle complexity (Larson, J., et al., 2011). However, the growth in the use of FSD could indicate a large resource use that is of value to study with regard to comparative ECS or eco-labels with context. The market size and developments must be researched to gain insight into this point.

The use of different materials or composites, the use of various technologies, the various geographic locations of production, the trade of these items must all be researched to gain insight into this business field. FSD are often coated to be able to hold humid and fatty products and are often coloured with additives. The articles are light weight and the question is raised if the additional additives influence the outcomes of environmental comparisons. The country of origin influences the travel distance but can also aid in determining the source of energy used to manufacture the article. A quick search on trade websites like Alibaba show a tremendous number of traders of FSD without having insight into where the articles have been produced. Traders in Europe can buy their articles from any source and deliver them to their clients who will offer them to the user.

As a user it is difficult to see or know where most FSD come from. Sometimes there is a name of a company on the item, which makes it possible to find the production site, but mostly the source of the manufactured article is unknown. As energy impact could be a major factor in quantifying the environmental impact of an article, it would appear of significant importance to identify its source or country of origin.

It is cited that the greatest challenge in creating applicable PCR is in convening a representative group of stakeholders (Ingwersen, W.W., et al., 2012, p. 106) and this could be the case for such a competitive and multiple source product group such as FSD. Specifically, Ingwersen states:

1. Because of the diversity of approaches to modeling product systems found in LCA and carbon footprinting, alignment is not likely to take place without dedicated efforts involving multiple stakeholders.

2. Perhaps the greatest challenge with respect to creating a globally applicable PCR is convening a representative group of stakeholders. 
In the context of this study, the term stakeholder is taken to mean any actor who could have product economic inventory data that could facilitate the development of a product LCA. It is understood that not all stakeholders will be absent at the same time. Stakeholders providing data related to the end-of-life scenario may be more available while stakeholders with product composition and product source data may not.

The question is what happens with the inventory input to LCA if there is no stakeholder input? The significant number of traders and the unknown production sites can make it hard to compare different items. Another question is what the variance will be in output of LCA, due to differences in methodology and choices in product economic inventory input approach, that may affect the degree of burden on the health of the planet compared with another like functionality FSD?

If the materials, the production site, processes, the way of packing, the way to transport, the route etc. is known, an LCA can be executed. If the production site or the country of origin is not known and if there is no material specification or stakeholder input, the question is how to formulate or judge a claim and how to compare different items?

To understand the rationale behind the FSD claims and to be able to compare different FSD, the scope of this study must firstly focus on the functionality of the item and how to obtain quantitative input for the product economic inventory step of an LCA. This is taken up in Figure 1.3.

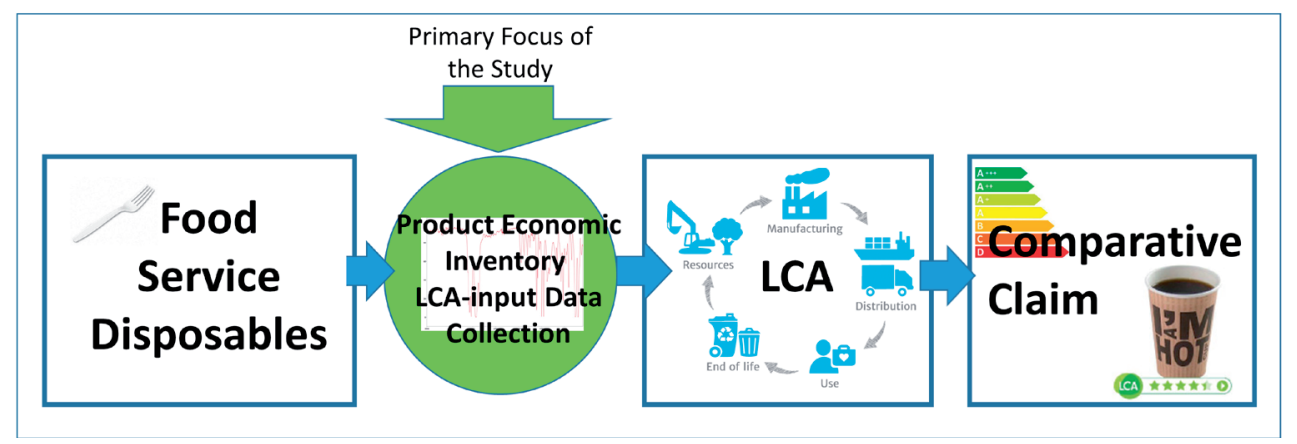

Figure 1.3: Primary Focus Area of the Study 


\subsection{Central Research Question}

The material composition and location of production of most FSD is unknown, this has to do with the wide spread of trade in these articles. On that basis, the foregoing research questions can be formulated. With the central research question (CRQ) of this study being:

\section{CRQ: Is it possible to develop a method to optimize the quality of product economic inventory LCA input data, in support of product LCA based comparative claims, in the presence and absence of stakeholder cooperation?}

To answer the central question, the following main research questions are posed:

Part 1-Describing the product, LCA, Comparative ECS and Product Economic Inventory.

1a. What are the factors that need to be addressed in developing a method?

Part 2 -Studying the factors to be addressed in developing a method.

2a. How should the comparative functional specification and functional unit be addressed?

2b. How should the product material composition and process quantification be addressed, if this is unknown?

2c. How should the country of origin ( $\mathrm{CoO}$ ) identification be addressed, if this is unknown?

$2 \mathrm{~d}$. Are there further considerations that need to be identified in developing the method?

2e. What form could such a potential method take?

Part 3 - Testing, evaluation, critique and conclusion.

3a. To what extent could the use of a potentially identified method for LCA input derive a different result from a visual based method or other common product economic inventory identification methods and what are the sensitivities of such a method?

3b. Could the use of an identified method potentially increase objectivity and could this lead to a more valid comparative product claim in the absence of stakeholder input? 
Table 1.2 below presents an overview of how each research question (RQ) is addressed within the theoretical and empirical parts of the research and the associated chapters (Ch).

Table 1.2: Location of RQ with the Study

\begin{tabular}{|c|c|c|c|c|c|c|c|c|c|c|c|c|c|}
\hline & \multicolumn{9}{|c|}{ Theoretical Part } & \multicolumn{4}{|c|}{ Empirical Part } \\
\hline & Ch1 & Ch2 & Ch3 & Ch4 & Ch5 & Ch6 & Ch7 & Ch8 & Ch9 & Ch10 & Ch11 & Ch12 & Ch13 \\
\hline \multicolumn{14}{|l|}{ RQ 1a } \\
\hline \multicolumn{14}{|l|}{ RQ 2a } \\
\hline \multicolumn{14}{|l|}{ RQ 2b } \\
\hline \multicolumn{14}{|l|}{ RQ 2c } \\
\hline \multicolumn{14}{|l|}{ RQ 2d } \\
\hline \multicolumn{14}{|l|}{ RQ 2e } \\
\hline \multicolumn{14}{|l|}{ RQ 3a } \\
\hline RQ 3b & & & & & & & & & & & & & \\
\hline
\end{tabular}

Regarding the reference to parts 1,2 and 3 above, these parts are visible in Figure 1.4 below:

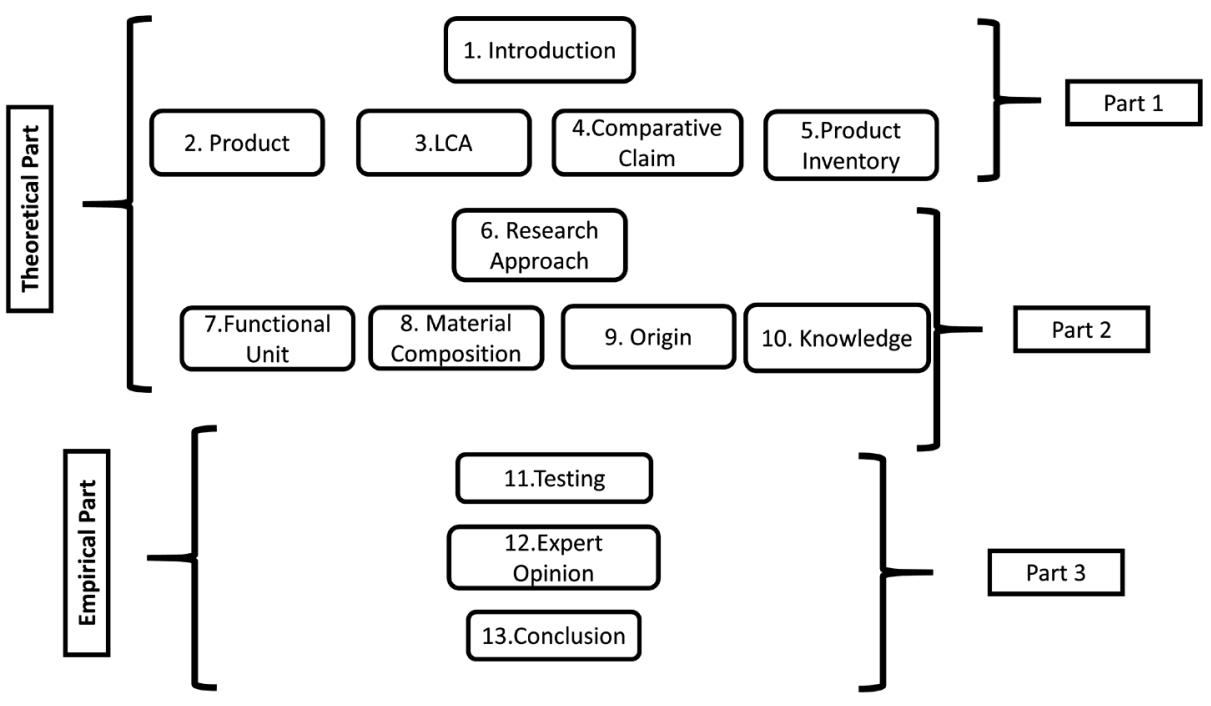

Figure 1.4: Study Parts, Chapters and Outline 


\subsection{Structure of the Thesis}

The structure of the study incorporates the following chapters:

\section{Part 1}

1. Chapter 2 will go into detail on FSD: a definition of FSD will be presented, the production chain will be described and the market, claims and developments will be shown. Current ECS related to FSD will be studied as will existing comparative ECS approaches.

2. Chapter 3 will introduce Life Cycle Assessment and the factors within LCA relevant to the study of a method for identifying LCA product inventory input.

3. Chapter 4 will review ISO, PEFCR and EPD rules focusing on aspects that could pose challenges with regard to FSD and their associated comparative claims, primarily from an LCA product inventory input perspective.

4. Chapter 5 will study the current product economic inventory input identification methods based on several sources.

\section{Part 2}

5. Chapter 6 will introduce the scoring method against which the various issues being tested can be judged.

6. Chapter 7 will address the functional unit (FU) within a comparative study and the influence of the FU choices and category rules on the relative position of a product within a category of like functionality products in a comparative ECS.

7. Chapter 8 will address the identification of the material composition and conversion processes of FSD with regard to LCA input and their influence on the relative position of a product within a category of like functionality products in a comparative ECS.

8. Chapter 9 will address the identification of countries of origin of FSD with regard to LCA input and their influence on the relative position of a product within a category of like functionality products in a comparative ECS.

9. Chapter 10 will address the value of sector specific technically relevant knowledge with regard to the development of LCA input data for FSD, specifically studying erroneous data in published LCA studies and their effect on the rating and ranking of products within a comparative ECS.

\section{Part 3}

10. Chapter 11 will test the proposed methodology across a range of diverse FSD.

11. Chapter 12 will seek expert opinion and advice as regards the findings of the study to identify limitations in the developed methodology.

12. Chapter 13 will be the concluding chapter and will list the major findings, challenges, conclusions and further studies identified from the research within this study. 


\section{PART 1}

\section{Chapter 2}

Food Service Disposables and Environmental Claim Statements 


\subsection{Introduction}

To be able to research the product environmental footprint (PEF) and environmental claim statements (ECS) of food service disposables (FSD), insight is needed into FSD. This chapter will therefore go into detail about FSD and their associated ECS. Before methods can be developed, there is a need to understand what FSD are, if there are definitions or if a definition can be formulated, how big the market is, what kind of materials are used, where and how they are produced, how trade is dealing with FSD, etc.

The chapter will first look into the history of FSD and the market size followed by a definition of FSD. The chapter will go into detail as regards the following topics:

1. What are FSD?

2. What definition and characteristics can be applied to the category of products called FSD?

3. What are examples of FSD?

4. What does the FSD production chain and FSD market look like?

5. Are ECS being applied to FSD and what kind of ECS are being used on FSD?

6. How is the market of FSD developing?

7. What is known about the acceptance of comparative ECS in the market?

8. What could be learnt from these existing comparative ECS?

9. Does comparing FSD makes sense and what is needed to do that?

\subsection{History of FSD}

It is remarkable that there are few scientific publications that can be found about environmental considerations regarding FSD. FSD do appear in some studies in which the environmental impact of one-way items is compared with that of reusable items and disposable cups do appear in studies relating to LCA methodology.

In 1908, a Dr. Samuel Crumbine saw a tuberculosis patient of his drinking from the communal water bucket in a train. Immediately after, a young girl drank from the same bucket. Horrified by the implications of this, he launched a campaign to ban common use utensils in public places (Stascak, J., 2017).

This led to the invention of the paper cup by Lawrence Luellen and Hugh Moore (Byron, D. J., et al., 2013). Together they began dispensing individual servings of water for one dollar cent for a five-ounce cup from a tall, clumsy porcelain water cooler. Soon they were the Individual Drinking Cup Company of New York and had renamed their sole product the Health Kup (with a ' $K$ '). The cup is seen as a lifesaving drinking technology that could help prevent the transmission of communicable disease and aid the campaign to do away with free water offered in communal cups, "tin dippers," found in public buildings and railway stations. A remarkable history of the introduction of FSD (Smithsonian website, accessed 01/12/2015), (Fisher, L. E., 2008). 
Moore asked the doll maker of Dixie Doll Company if he could borrow their name for the cup. At the same time, an automatic machine was being introduced that could provide two flavours of ice cream, ushering in paper-wrapped wooden scoops and disposable cups known as Ice Cream Dixies, hence establishing the use of the paper cup.

The word "disposables" nowadays commonly refers to trays, cups, plates, cutlery and wipes used in the food service industry (Durocher, J. F., 1982) for which there is a single use and no need to be returned to the point-of-sale.

FSD are throw-away, single use, disposable items and as such have developed a negative image despite their contribution to public health. If "packaging" has a negative image then surely there is no worse image than "disposables" as relates to our "throw-away society" (Power, K., et al., 2010). As early as 1955 reference to the "throw-away society" was given in the Life magazine article of 01/08/1955 titled "Throwaway Living".

The term "disposables" also refers to those single use items used to replace the existing durable or reusable tableware items. Disposables permit the sanitary consumption of food and drink while on the move (Felix, C. W., 1990). It could be said that for many food service outlets to function disposables such as a cup, fork, plate or serviette are essential. Consumption of on-the-go, out-of-home, carry-out or take-away food largely requires disposables.

FSD have become single use disposable items used by the food service sector. There are many other single use items being used for hygienic or sanitary reasons such as medical disposables, as well as many not directly associated with a hygienic consideration, such as razors, pens, cosmetic applicators and many packaging items that have use functionalities and have replaced durables like pots and trays. Examples are margarine tubs, marmalade jars and aerosolized cans with cream. For a short period, even single use cameras were on the market. Single use has become a way to sell convenient product functionalities to the market and the development is still on going, as can be seen in an average supermarket.

Examples of food service disposables are:

- Plastic cutlery

- Wood and plastic stirrers

- Carton and plastic drinking cups

- Carton and plastic plates

- Paper serviettes, napkins, placemats and table covers

- Paper block bottom take-out bags

- Carton, plastic and aluminium trays

- Plastic cling film and aluminium foil

FSD are not covered by any single Classification of Product by Activity (CPA) code. The same FSD product functionality can be derived from various differing materials or material 
conversion processing. Product Environmental Footprint (PEF) requires that CPA be used in defining the product category; however, Product Environmental Footprint Category Rules (PEFCR) state that a multi-CPA approach can be taken (PEF Guide, 2012). Product Category Rules (PCR) defined by Environmental Product Declaration (EPD) also require classification using the UN CPC scheme for which there is also no specific code for FSD (EPD General Program Instructions 2015).

The diversity and source of FSDs is considerable. Items of like functionality can come from a large number of likely countries of origin, could be made using a large array of different materials and composites, and manufactured using a wide range of applicable conversion processes. In Figure 2.1 below, the beverage stirrers have the same functionality but all are made using different materials and conversion processes, notably injection moulded polystyrene composite, extruded polypropylene composite and cut wood.
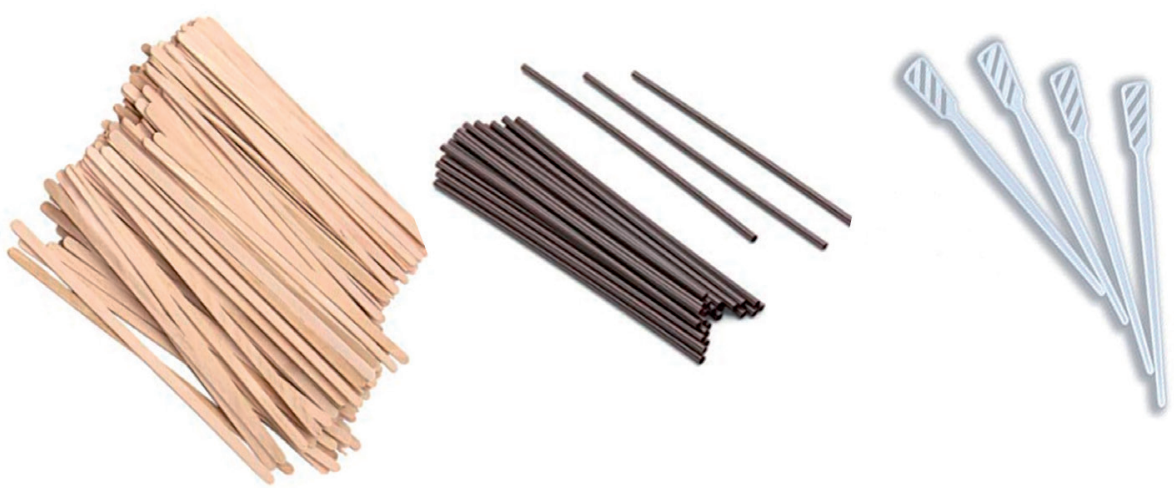

Figure 2.1: Beverage Stirrers

FSD are often fit-for-purpose designs using the minimum of resource for their single use function. They are often of very low weight and value and are seen by most food service operators as cost-items of little interest other than for the direct function they provide. In Figure 2.1 above, the wooden stirrer weighs 1.0g, the white polystyrene spatula type beverage stirrer weighs $0.41 \mathrm{~g}$ and the extruded polypropylene stirrer stick weighs $0.38 \mathrm{~g}$. Minimum resource use may partly be derived from the fact that the FSD sector is also seen as one of considerable competition (Bunz/ website, accessed 21/01/2016) (Interviews 20/06/2017 with Various FSD Purchasers in Appendix B).

Health is an issue related to FSD. Attention will be paid to this. The use of FSD is wide spread and global. The market size of FSD is related to the market of food service and will be explored, as will the associated demand on global resources for FSD. A definition will then be formulated that will be used in this research. 
The three primary reasons given, in Fisher, L. E., 2008, as to why businesses favour disposable products are sanitation, cost, and, foremost, convenience. FSD require no cleaning and do not need to be returned as they can be easily discarded after use, making them ideal for take-out food service.

FSD are often seen as packaging but the functions of packaging are rather different because protecting/conserving a product during a certain time, distributing a product across a certain distance, providing information about the content and supporting sales, vary from those of FSD (Klooster, R. ten, 2002).

\subsection{FSD and Public Health}

This subchapter seeks to understand the health benefits related to the use of FSD. Major benefits of single use disposable items are improved hygiene and better public health. This "single use" of an item is an important element of food safety, preventing the persistence and transfer of any contaminating bacteria or viruses (Klick J., et al., 2013).

The American Food and Drug Administration's Food Code requires that "A food establishment without facilities ... for cleaning and sanitizing kitchenware and tableware shall provide only single-use kitchenware, single-service articles, and single-use articles for use by food employees and single-service articles for use by consumers." The Food Code further states "in situations in which the reuse of multiuse items could result in foodborne illness to consumers, single-service and single-use articles must be used to ensure safety." (FDA website, accessed 01/12/2015).

Numerous sources and articles can be found about the hygiene aspects of FSD. Some of them are taken up here:

1. A study by the Food Service Packaging Institute involving coffee bars, restaurants, delis and day care centres in Clark County, Nevada, USA, found that 18 percent of reusable food service items tested (like cups, plates, bowls and utensils) were unclean; they had more than the generally accepted standard of 100 colonies of bacteria per item. According to a study by the Food Service Packaging Institute in 2002, only 8 percent of the single use items tested exceeded that standard (FPI website, accessed 12/11/2015).

2. In addition, the use of paper placemats, or tray covers, provides a more sanitary eating surface than uncovered tabletops or trays. According to a 2006 study by the University of Wisconsin, Oshkosh, USA placemats were shown, on average, to have just 14 percent of the bacteria found on uncovered tables in restaurants. Similarly, tray covers were shown, on average, to have as little as five percent of the bacteria found on uncovered trays in hospitals, lodgings and long-term care facilities (FPI website, accessed 12/11/2015). 
3. A public health study in Taiwan titled "Decrease in seroprevalence of Hepatitis A after the implementation of nationwide disposable tableware use in Taiwan" (Shih-Bin Su, et al., 2010) cites the potential public health benefits derived from the use of disposable tableware. However, in 2006 disposable tableware was banned in schools and governmental agencies in Taiwan, including the paper cup in 2007. In 2008, governmental policy was set up to minimize the use of disposable chopsticks in cafeterias and stores and in 2011 an obligation was enacted for fast food and convenience stores to give discounts to customers who bring their own cups (no-burn website, accessed 01/12/2015).

4. A report from the World Union of Wholesale Markets related to the Netherlands, which set the guidelines for street food providers, was identified in which the use of disposables was encouraged. However, as of 01/01/2014 the Ministry of Health had revoked its approval for this guideline, as a result of the request of Hoofdproductschap Detailhandel, a branch organization with some legal rights at that time (Staatscourant 2013). A study of the documents pertaining to disposables within the Netherlands is to be found in Appendix A.

Consumers could be encouraged to use reusable packaging, bags and FSD (Sharp A., 2010) (Poortinga W., 2013), but there is considerable evidence that these items could become contaminated with foodborne pathogens. Studies of the microbial status of these reusable items, once they are in use, confirm that they are not being frequently and adequately decontaminated (Sinclair R. G., 2016) (Sinclair R. G., 2018).

It could be said that FSD provide a sanitary solution to the consumption of food on-the-go and as such provide a valuable service to society. Little scientific research has been carried out with regard to the size of the FSD market. However, the food service market has been researched and can help to provide insight into the FSD market size.

\subsection{The Food Service Sector and Market Size}

This subchapter will explore the global economic value and the potential size of the global resources that FSD consume. To gain insight into this market, initial insight is needed as relates to the food service market, what is meant by food service and to quantify the size and value of the food service business. 
Popular definitions of food service can be seen below:

1. Food service (US English) or Catering Industry (British English) defines those businesses, institutions, and companies responsible for any meal prepared outside the home. This industry includes restaurants, school and hospital cafeterias, catering operations, and many other formats. (As cited on Wikipedia 2010, accessed 01/12/2015.)

2. The preparation, delivery, serving, etc., of ready-to-eat foods. (As cited in the Random House Dictionary, 2010, accessed 01/12/2015.)

3. The practice or business of making, transporting, and serving or dispensing prepared foods, as in restaurant or commissary. (As cited in The American Heritage Dictionary, 2009, accessed 01/12/2015.)

Probably the most important part of the definition of food service is the term "out-ofhome". Food service is the supply of food for consumption outside of the home and is the natural competitor to the food retail business.

Fundamentally, any business facilitating out-of-home eating and/or drinking could be defined as a food service business. Examples are:

1. In-transit feeding (in-flight, trains, ferries, cruise ships, coaches)

2. Institutional catering (prisons, schools, state offices, hospitals, nursing homes)

3. Food on the move (stations, airports, motorway restaurants, gas stations)

4. C-Stores (convenience stores such as 7-Eleven stores, AH To-Go)

5. QSR (quick service restaurants, such as McDonalds, KFC, Subways)

6. Coffee (Starbucks, Exki, Pret A Manger)

7. Catering (events, employee feeding)

8. Vending and snacks

9. FSR (full service restaurants)

10. Lodgings (feeding in hotels, motels, hostels)

11. Recreation (concerts, sports, theme parks, museums)

12. Bars and taverns

13. Ice cream bars and juice bars

14. Food retailers supplying FSD and foods for picnics, BBQ, camping and other outdoor activities

Unklesbay identified four types of food service operations (Unkelsbay N., 1977):

1. Conventional or traditional

2. Ready prepared

3. Commissary

4. Assembly/serve 
These types of food service operations are further cited in the study by Payne-Palacio, J. 2009 (Payne-Palacio, J., et al., 2009).

The term food service, in this study, will relate to food and drink that is consumed away from the home, either at a fixed location or on-the-move, and will involve the use of FSD.

Consumers are increasingly consuming food away from home (Naska A., et al., 2015) (https://cordis.europa.eu/results/rcn/47517_en.htm/).

"Global sales of food, including food sold through food service establishments, are estimated at [US]\$4 trillion in 2002. Over 40 percent of the total value of global food sales is currently accounted for by the food service sector. With consumers increasingly demanding convenience, it is likely that the value of global food service sales will overtake global retail food sales in the future. The demand for convenience is not limited to consumers in developed countries. In the developing countries, rising demand for convenience is reflected by the rapidly expanding fast food sector" (Geh/har, M., et al., 2005).

The global food sales per retail and food service sector, per food type, for sales in 2002 , can be seen in Table 2.1 below:

Table 2.1: Global Food Sales 2002, US\$ billions - Retail versus Food Service

\begin{tabular}{l|ccc} 
& Retail Stores & Food Service & Total \\
\cline { 2 - 4 } Fresh food & 531 & 382 & 913 \\
\hline Processed products & 1762 & 1420 & 3182 \\
\hline Packaged food & 1148 & 828 & 1976 \\
\hline Beverages & 614 & 592 & 1206 \\
\hline Alcoholic drinks & 316 & 422 & 729 \\
\hline Hot drinks & 53 & 12 & 65 \\
\hline Soft drinks & 245 & & 412 \\
\hline & & 167 & 4096 \\
\hline Total & 2293 & & \\
\hline
\end{tabular}

Source: Euromonitor 2003

Many commercial market studies approximately underline the figures of Gehlhar.

In a 2011 Marketline report (Marketline website, accessed 01/12/2015), the global food service market in 2010 was estimated to be valued at €1.6 trillion, which was broken down into commercial channels (83\%) and institutional channels (17\%). In a study by prweb.com (prweb website, accessed 12/11/2015) of the 23/06/2009, the food service market was projected to reach US\$2.2 trillion in 2015. In 2013, the IMF estimated the world GDP to be US\$98.4 trillion in 2015 , hence this would value the food service business at approximately $2.2 \%$ of GDP. 
According to a 2010 Pro-Intel study (Bordia website, accessed 12/11/2015), the food service market remains skewed towards the developed economies - North America, Western Europe and Japan. These three regions currently account for $56 \%$ of global food service value with just $15 \%$ of the global population. Food service spend per capita is highest in Japan, followed by the USA and Western Europe.

The Pro-Intel 2010 study breakdown of European food service sales by channel in $€$ billion can be seen in Table 2.2 below which totals $€ 260.53$ billion:

Table 2.2: European Food Service Sales by Channel

\begin{tabular}{l|c|c}
\hline Food Service Operation & 70.20 & € billion \\
\hline Full Service Restaurants & 49.13 & 19 \\
\hline Cafes, Bars, Bakeries & 33.90 & 13 \\
\hline Quick Service Restaurants & 25.20 & 10 \\
\hline Business \& Industry & 23.40 & 9 \\
\hline Hotels, etc. & 19.50 & 7 \\
\hline Other (Street, Hawkers) & 14.30 & 6 \\
\hline Health & 7.60 & 3 \\
\hline Leisure & 4.40 & 2 \\
\hline Vending & 6.60 & 2 \\
\hline Education & 2.80 & 1 \\
\hline Travel & 3.50 & \\
\hline Government & $\mathbf{2 6 0 . 5 3}$ & \\
\hline Total $€$ billion & & \multirow{2}{*}{} \\
\cline { 1 - 3 } & &
\end{tabular}


Between 1977-78 and 2005-8, food away from home, particularly fast food, provided an increasing share of the calories within the USA diet (USDA, National Health and Nutrition Examination study 2008). This increase can be seen in Figure 2.2 below:

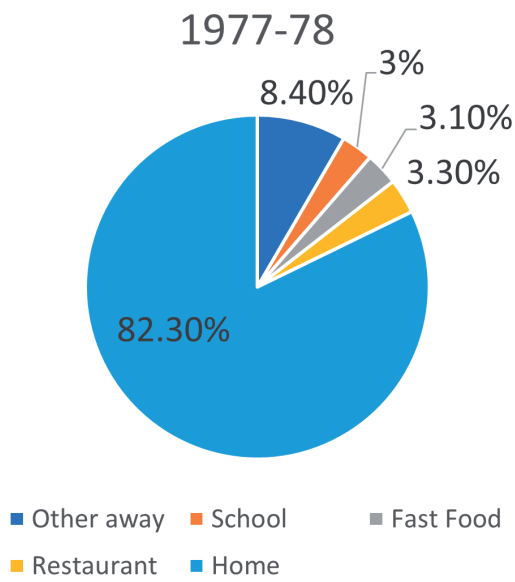

2005-08

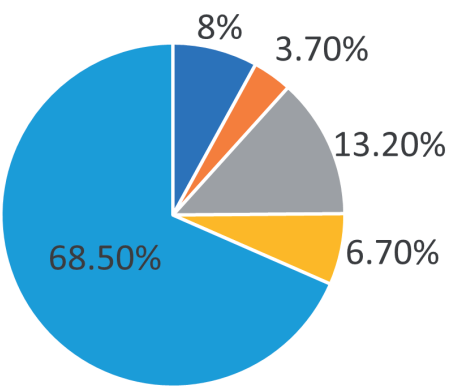

- Other away School

- Restaurant $=$ Home

Figure 2.2: Increase in Fast Food Consumption in the USA

In the USA Centers for Disease Control and Prevention report 213 of September 2015, it states: "In 2011-2012 children and adolescents consumed on average 12.4\% of their daily calories from fast food restaurants." (CDC website, accessed 27/10/2015.)

To put the value of Food Service into per capita terms, a study by the NPD Group/Crest in 2010 (NPD website, accessed 27/10/2015) cited the Spanish spending the most at €987/ year, the British €959/year, the Italians €913/year, the Germans €791/year and the French $€ 777 /$ year. Additionally, there are also cultural impacts as relates to the use of Food Service.

A Rocket-Internet study indicated the global takeaway food delivery market to have been worth $€ 90$ billion in 2014 with the total global food retail market in 2013 being worth $€ 4.7$ trillion (Rocket Internet website, accessed 20/06/2017).

A PIRA-Smithers study in 2013 (Foodnavigator-asia website, accessed 27/10/2015) reported that the Chinese Food Service packaging market will overtake the USA market by 2020. The report states that the USA is currently the largest market for FSD, stating that this is expected to increase by 17\% between 2011 and 2016. However, they cited that China's disposables market is growing at a faster rate and has long-term growth potential. 
In 2010, the Dutch Food Service Institute cited the total turnover in the Netherlands Food Service market as 18.1 billion Euro in 2009, as can be seen in Table 2.3 below. This is approximately $32.5 \%$ of the total Dutch food sector.

Table 2.3: The Food Service Market in the Netherlands (FSIN 2010)

\begin{tabular}{l|c|c|c}
\hline \multicolumn{1}{c}{ Markets } & $\begin{array}{c}\text { Customer Transactions } \\
\text { 2009, in billions }\end{array}$ & $\begin{array}{c}\text { Turnover 2009 } \\
€ \text { billion }\end{array}$ & $\begin{array}{c}\text { Average Spending/ } \\
\text { Transaction 2009 }\end{array}$ \\
\hline Food Service Total & 2.84 & $€ 18.10$ & $€ 6.37$ \\
\hline Horeca* & 0.93 & $€ 9.21$ & $€ 9.90$ \\
\hline Catering & 1.12 & $€ 3.45$ & $€ 3.08$ \\
\hline Convenience & 0.79 & $€ 5.43$ & $€ 6.84$ \\
\hline
\end{tabular}

*Horeca stands for hotel, restaurant and cafe (bar)

To compare the global Food Service market (US\$1803 billion) to the global food market; the food market is estimated to be worth US\$7 trillion in 2014 according to a 20/10/2013 study by Businessvibes (Endersen, L., et al., 2014), making the Food Service business approximately $25.8 \%$ of the global food business, based on the above prweb.com Food Service market figure for 2015.

Today the Food Service industry supplies up to 47\% of USA food and drink consuming times; Americans spend nearly 50\% of their food budget on Food Service (Schlosser, E., 2012). It must be remembered that many Food Service activities are an important part of a nation's pastime activities. If leisure time grows then this could have a positive effect on the Food Service business. According to a 2010 study by the National Restaurant Association (Restaurant.org website, accessed 27/10/2015), it was cited that in 1970 Americans spent around US\$6 billion on QSR fast food; by 2000 this had risen to an estimated US $\$ 110$ billion. At the time this was more than was being spent on other pastimes, such as movies, books, magazines, newspapers, videos and recorded music combined as was cited in the 2001 book Fast Food Nation written by E. Schlosser (Schlosser, E., 2012).

The largest franchise sector in the USA is the QSR sector which was cited as going to employ 3.2 million people in 2014 (http://emarket. franchise.org, accessed 01/05/2012).

The QSR sector in Belgium is comprised of 16147 outlets in 2014 with a turnover of $€ 3.2$ billion (Foodservicealliance website, accessed 27/10/2015). The convenience food outlet market in the Netherlands in 2012 had a turnover of $€ 5.56$ billion (FSIN, accessed 27/10/2015), with the total Dutch Food Service market consisting of 166492 outlets in 2013 (Foodstep website, accessed 27/10/2015) and 412000 jobs in 2012 (CBS website, accessed 27/10/2015).

According to Euromonitor, the Chinese food service sector is the largest worldwide with $€ 440$ billion turnover in 2014 and 7.3 million outlets (CCILC website, accessed 27/10/2015). 
Table 2.4: National Food Service and Quick Service Restaurant Market Sizes

\begin{tabular}{|c|c|c|c|}
\hline Source & Item & Value US\$ billion & Year \\
\hline Food Service Alliance & QSR Belgium & 3.5 & 2014 \\
\hline National Restaurant Association & QSR USA & 110.0 & 2000 \\
\hline Euromonitor & Food Service China & 484.0 & 2014 \\
\hline Food Service Institute & Convenience Netherlands & 6.1 & 2012 \\
\hline
\end{tabular}

Table 2.5: An Overview of Figures from Market Analysis Companies related to the Global FoodMarket Size used in the above Text

\begin{tabular}{l|l|l|l}
\hline Report Source & \multicolumn{2}{c}{ Value US\$ } & Year \\
\hline Gehlhar & Food, Global & $4.00 \mathrm{E}+12$ & 2002 \\
\hline Businessvibes & Food, Global & $7.00 \mathrm{E}+12$ & 2014 \\
\hline Marketline & Food Service, Global & $1.60 \mathrm{E}+12$ & 2010 \\
\hline prweb.com & Food Service, Global & $2.20 \mathrm{E}+12$ & 2015 \\
\hline Pro-Intel & Food Service, Global & $2.84 \mathrm{E}+11$ & 2010 \\
\hline IMF & GDP, Global & $9.84 \mathrm{E}+13$ & 2015 \\
\hline
\end{tabular}

rate 1 US $\$=0.92$ Euro $(04 / 10 / 2015)$

Another aspect that can be taken into account is the daily time spent on preparing food, which is decreasing (Smith, L et al., 2013). Consumers often rely on food purchased in a partially or fully prepared state. A large amount of food is also delivered by supermarkets in disposable packaging, such as fresh ready meals and snacks. A study by Deloitte in 2012 (Deloitte website, accessed 01/12/20105) cited that convenience remains a major driver in the food industry, and consumer use of Food Service reduces overall daily cooking time from 20 minutes to 7 minutes.

It can be concluded that the Food Service sector is a considerable and growing portion of the world economy with a turnover of no less than US\$2 trillion/annum.

\subsection{Resource Size of FSD}

A significant portion of the Food Service sector uses FSD. To understand the value in terms of the resource size going into FSD, data has been collected related to coffee cups. The choice of the coffee cup as the disposable item most referred to in this study relates to the larger number of LCA orientated studies of this item compared with other disposable items (Ligthart, T. N., et al., 2007), (van der Harst, et al., 2013), in addition to the considerable presence of disposable coffee cups evident in society.

Coffee is the second largest traded commodity by value in the world (Fitter, R., et al., 2001), trading some 7 million tons per year. The Dutch were the first Europeans to enter the coffee trade, importing coffee plants from the Malabar Coast of India to their colonies in what were then called the Dutch East Indies, or present-day Indonesia (Davids, K., 1996). 
The coffee industry employs 25 million people around the world (Fitter, R., et al., 2001). Americans are the world's leading coffee consumers. They consume 450 million cups of coffee per day, or more than 150 billion cups a year (Lorenzetti, D., 2000). The same figure from Fisher E. 2008 is stated as being 130 billion cups a year. A Live Science study in 2012 (http://www.livescience.com, accessed 01/12/2015) put the total amount spent on specialty coffee in the USA in 2011 at an estimated US\$18 billion. One third of the tap water used for drinking in the USA is used to brew daily cups of coffee (Kostigen, T., 2008).

In 2011, the UK Daily Telegraph newspaper (Telegraph website, accessed 01/12/2015) stated that branded coffee shops in the UK alone have grown from 3492 outlets in 2007 to 4645 in 2010 with an estimate of 5719 in 2013. A later BBC article from 2017 stated there were 22000 coffee outlets in the UK, selling some 2.3 billion cups of coffee a year (BBC, 14/09/2017). Today, the UK market for vending cups is over 6 billion pieces per annum.

A 2009 franchise study stated that the coffee shop industry in the USA included 20000 shops with combined annual revenue of about US\$11 billion.

A study by Allegra Strategies in 2012 (Allegra Strategies website, accessed 01/12/2015) cited the takeaway coffee sector in the UK as being worth $£ 6.3$ billion. The report stated that in the price of a $£ 2.20$ cup of cappuccino, $£ 0.08$ is the coffee and $£ 0.16$ is the disposables. Assuming all coffees in the sector costs $£ 2.20$, this would make the value of the disposables in the sector worth approximately $£ 458$ million per annum in the UK.

In 2010, Starbucks reported (Fastcompany website, accessed 01/12/2015) the use of 3 billion cups out of the "nation's 200 billion-plus paper cups". An average 8oz Paper/PE cup weight is $10 \mathrm{~g}$ (popular cup sizes in the USA range from $80 \mathrm{z}$ to $16 \mathrm{oz}$ ) and this equates to a net amount of 2 million tons of Paper/PE hot cup stock just for the paper coffee cups used in the USA.

Woods, L et al., 2014, citing data from The Freedonia Group, stated that globally over 500 billion disposable cups are sent to landfill every year.

Table 2.6: Overview of Reported Cup Quantities in the UK and the USA

\begin{tabular}{c|l|c|c|c}
\hline \multicolumn{1}{c}{ Country } & \multicolumn{1}{c}{ Source } & Year & Quantity billion/year & Resource tons/year \\
\hline UK & Daily Telegraph & 2016 & 6.0 & $60000^{*}$ \\
\hline UK & Allegra Strategies & 2012 & 2.9 & $28633^{*}$ \\
\hline UK & BBC & 2017 & 2.3 & $23000^{*}$ \\
\hline USA & Lorenzetti & 2000 & 150.0 & $1500000^{*}$ \\
\hline USA & Fisher & 2007 & 130.0 & $1300000^{*}$ \\
\hline USA & Starbucks & 2010 & 200.0 & $2000000^{*}$ \\
\hline USA & Woods, L., et al. & 2014 & 500.0 & $5000000^{*}$ \\
\hline
\end{tabular}

*estimate based on cup weight of $10 \mathrm{~g}$ 
Moving from the study of coffee cups to FSD in general, a PIRA-Smithers report - The Future of Foodservice Packaging and Disposables to 2016 - states that they forecast the global market at almost US $\$ 40$ billion by 2016, with a growth rate of 2.4\% (Smithers Pira website, accessed 27/10/2015).

"World demand for food service disposables is forecast to grow 5.4 percent per year to [US]\$53.3 billion in 2015". "Disposable serviceware - including single-use cups, dinnerware and utensils -- will remain the largest product type through the forecast period and beyond." (Freedonia Group website, accessed 21/10/2015).

Table 2.7: Overview of Reported Global FSD Market Value

\begin{tabular}{c|l|c|c|c}
\hline \multicolumn{1}{c}{ Country } & \multicolumn{1}{c}{ Source } & \multicolumn{1}{c}{ Year } & Value US\$ billion/year & Growth Rate \%/year \\
\hline Global & PIRA-Smithers & 2016 & 40.0 & 2.4 \\
\hline Global & Freedonia** $^{*}$ & 2015 & 53.5 & 5.4 \\
\hline
\end{tabular}

*food service packaging and disposables

**food service disposables

Further indication of growth in FSD can be identified through the waste they generate. In 1960, 270000 tons of disposable plates and cups were used in the USA. By 1997, Americans generated 1830000 tons of waste related to these FSD products (GRRN website, accessed 01/12/2015).

It can be concluded that FSD consume significant resources and that it is not possible to identify reliable figures relating to the amount per type of material and per continent. The amount of resource consumed has grown in the last half century and would appear to continue to be growing into the near future.

\subsection{The Supply Chain from Raw Material to FSD}

Tables 2.8 and 2.9, and Figure 2.3 below review the materials, manufacturing processes and supply chain flow for FSD.

Table 2.8: Examples of Typical Materials Used in the Production of FSD

\begin{tabular}{|c|c|c|}
\hline Polymers & Cellulose & Others \\
\hline Polystyrenes & Tissue paper & Composites \\
\hline Polyethylenes & Kraft paper & Recyclates \\
\hline Polypropylenes & Bagasse board & Minerals \\
\hline Polyesters & Folding box board & Gases \\
\hline Poly Lactic Acid & Liquid packaging board & Aluminium \\
\hline Polybutylene succinate & Palm leaf & Lacquers/coatings \\
\hline Starch based polyester & Woods & Additives \\
\hline
\end{tabular}


Table 2.9: Examples of Conversion Processes in the Production of FSD

\begin{tabular}{l}
\hline Conversion Processes \\
\hline Pellet drying/mixing \\
\hline Compounding \\
\hline Film extrusion/co-extrusion \\
\hline Sheet extrusion/co-extrusion \\
\hline Thermo/vacuum forming \\
\hline Injection moulding \\
\hline Heat sealing \\
\hline Laminating \\
\hline Printing/coating \\
\hline Die Cutting \\
\hline Folding and gluing \\
\hline Cup forming (paper cup) \\
\hline Press forming \\
\hline Wetting/humidification \\
\hline
\end{tabular}

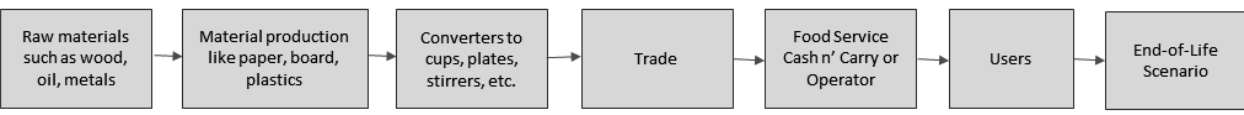

Figure 2.3: Example of the FSD Supply Chain

The FSD supply chain typically starts with extractive primary feedstock companies who sell on to the raw material production companies that supply the polymer granules or paper board. The quantity of companies involved at this initial stage is relatively small. These raw materials are then shipped to the FSD manufacturing companies, the number of companies in the FSD manufacturing stage of the supply chain is high. Traders typically have thousands of potential manufacturing sources listed, the Chinese trading site Alibaba lists 5800 suppliers of plastic disposable cutlery in mainland China (Alibaba website, accessed 06/03/2016). Global Sourcing cites 463 manufacturers of plastic cutlery in mainland China (Global Sources website, accessed 06/03/2016). While these two trading websites show very different quantities of suppliers, it can be seen that there are many.

Importers tend to be the larger national importers who can afford to finance import purchasing and the holding of stocks required to compensate for the often long lead times from the global FSD manufacturing market. Companies involved in the reselling of FSD in the Netherlands to the end user, amount to some 500 companies (Interview Depa and TVD, 2015; two trading companies in disposables in the Netherlands). As noted above, these resellers then sell on to the over 166000 food service operations in the Netherlands. 
Companies involved in the UK and USA FSD market have associations they can join to lobby on their behalf. The member quantities and types can be seen in Table 2.10 below. An interview with the head of the UK Food Service Packaging association put the UK market for FSD at approximately $£ 1$ billion/annum (interview Martin Kersh, Executive Director, Food Service Packaging Association, 29/03/2016).

Table 2.10: Converter and Distributor Members of the Foremost FSD Associations

\begin{tabular}{l|c|c|c}
\hline Food Service Disposable Associations & Territory & Converters & Distributors \\
\hline Food Service Packaging Association & UK & 57 & 78 \\
\hline Food Service Packaging Institute & USA & 33 & 105 \\
\hline Pack2Go & EU & 21 & 1 \\
\hline
\end{tabular}

(Food Service Packaging Website, Food Service Institute and Pack2Go websites, accessed 12/08/2016)

The FSD supply chain can involve many countries, as FSD is a global business. An example could be that a fossil feedstock is sourced in one country and moved to a further country for conversion into a polymer that is then shipped to a product manufacturer in a third country. This manufacturer may then export the product to a foreign trader who then re-exports the product on to a Food Service distributor.

Financial barriers to market entry are low, with some traders offering minimal order values of $€ 600$ per delivery to parties who then sell on to the end user at mark-ups of between 25 to 50\% (Interview with FSD traders, 2015, Appendix B).

With a large number of companies involved in FSD and low barriers to market entry, it could be seen that companies could and may face relentless competition. With so many companies in the industry, no mutual interdependence exists between companies. Whatever one company does will have little impact on the industry as a whole because many companies are small. In such a setting, companies might typically look out only for themselves, attempting to gain advantages over other small competitors.

To get an understanding of the source of the raw materials, the materials that are used, the location the items are produced etc., stakeholder information is needed. The high level of competition is likely to make it difficult to achieve stakeholder cooperation, which is cited as one of the greatest challenges in forming Product Category Rules (Ingwersen, W.W., et al., 2012). It could be seen that this could pose a significant challenge in establishing viable product economic inventory LCA input data for comparison of FSD. 


\subsection{Definition and Characteristics of FSD}

The definition of FSD that will be used in this study has to contain the basic elements that have been researched and found. Characteristics of FSD are:

1. A single use item

2. Contributes to public health, in that it provides the hygienic consumption of food and drink away from home

3. Convenient, as it does not have to be returned, ideal for take-out food service

4. They are an important tool for the functioning of the globally significant Food Service sector

5. Are mostly made out of wood, paper or plastics

6. Are made out of a minimum amount of material to achieve the functionality

7. Being produced by a large number of manufacturing companies

8. Being traded or imported by a smaller number of national importers

9. Being sold to end users by a large number of local resellers

10. Being used by a very large number of Food Service operations

11. Being sourced and used globally in increasing quantities

12. Putting pressure on material resources

13. Are subjective to high levels of competition due to the relatively low barrier to market entry

14. Have a bad environmental image because of their throw-away, single use, disposable nature

With reference to the cited definition of FSD above, being "disposables permit the sanitary consumption of food and drink while on the move" (Felix, C. W., 1990), the definition used in this study is:

Typically, FSD are products of minimalistic fit-for-purpose design, using the minimum of resource for their single use function of providing the sanitary consumption of food and drink while on the move.

Minimalistic fit-for-purpose design would cover very light weight uninsulated cups through to higher weight insulated cups, as is defined by their functional specification and the markets they serve. 


\subsection{The Current Environmental Claim Statements applied to FSD}

Table 2.11 below shows a list of examples of claim statements printed on hot beverage cups collected in the Benelux market in 2012. These are typically Type II (OECD. 1997. Eco-Labelling. Actual Effects of Selected Programme. Paris.) claims made by the supplier of the cup and not the Type I which require third party verification or Type III which are quantitative, according to the ISO standards regarding claims (see Chapter 1). The claims given in this study as examples of existing market claims will be mostly Type II claims.
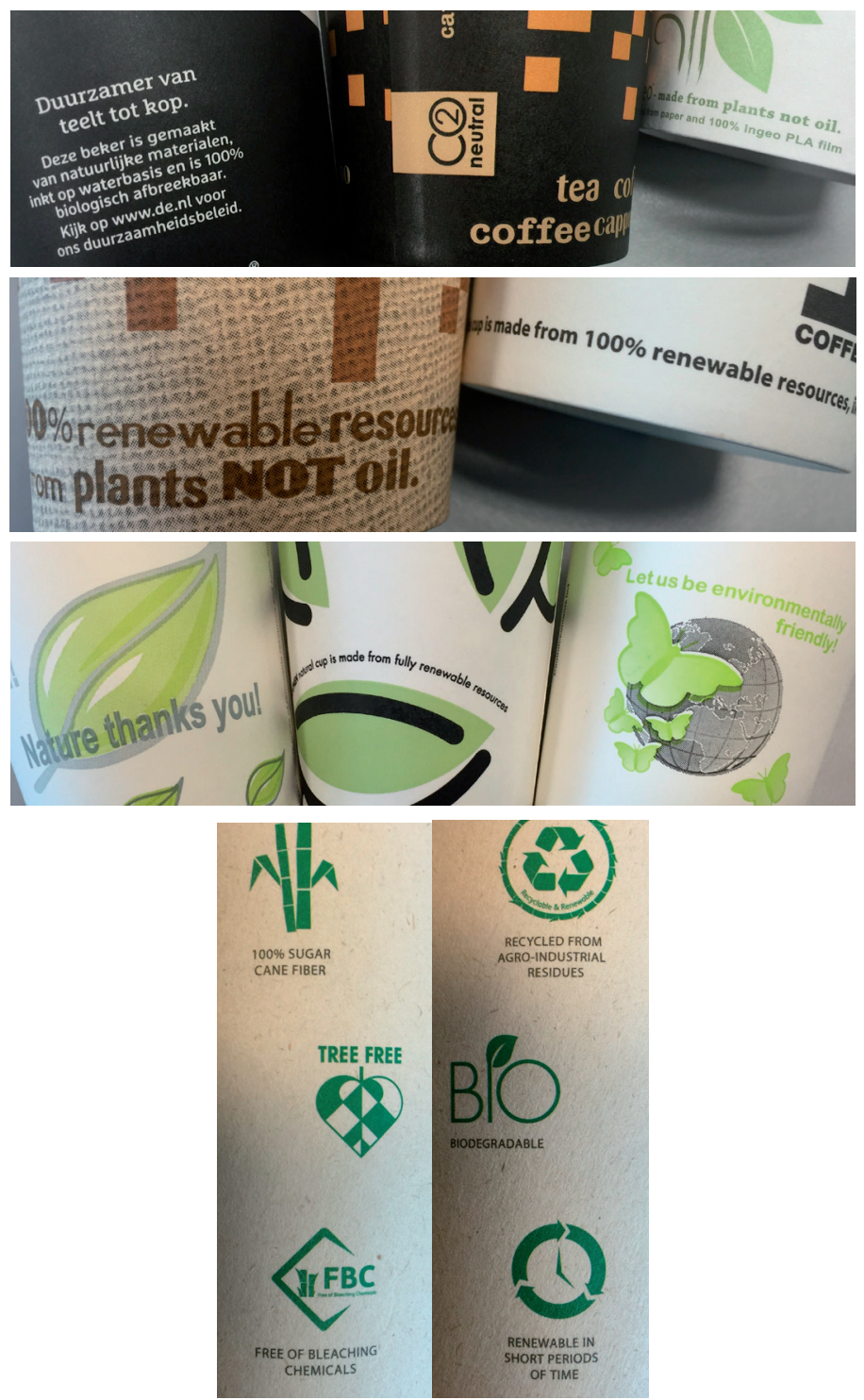

Figure 2.4: Examples of ECS on Paper Cups 
Table 2.11: Examples of ECS Printed on Hot Beverage Cups Collected in the Benelux Market in 2012

\begin{tabular}{|l|}
\hline $100 \%$ Duurzaam (100\% Sustainable) \\
\hline De Duurzaamste Beker (the most sustainable cup) \\
\hline This cup is made from $100 \%$ renewable resources \\
\hline Made from sugar cane and coated with corn \\
\hline $100 \%$ bio \\
\hline These resources are $100 \%$ renewable \\
\hline Nature Thanks You, Let us be Environmentally Friendly! \\
\hline $100 \%$ Biodegradable \\
\hline $100 \%$ Compostable \\
\hline This cup is made from 100\% renewable resources, inside coating made from plants not oil \\
\hline This cup is made from sustainable sources \\
\hline $100 \%$ bewust genieten (100\% conscientiously enjoy) \\
\hline
\end{tabular}

As qualitative ECS such as those above in Table 2.11 have proliferated, many have been discredited and it is evident that there is a need for transparent and quantitative information on products (Ingwersen, W.W., et al., 2012).

From the study of unsubstantiated ECS, it would appear that marketers feel they are free to claim whatever they want; they seem unaware of any standards or moral obligation to make relevant claims (Minneti, J. J., 2010), as per the claims in Figure 2.4 above.

To summarise:

1. Many types of ECS are made.

2. The claims identified were largely Type II claims.

3. No reference is made to a source of more information to support the ECS.

4. The claims do not seem to be based on scientific study.

\subsection{Comparative Banded Scale based Claim}

It is more difficult to calculate the embodied energy of an FSD compared to calculating the use-phase energy of, for example, a 100 Watt light bulb. The embodied energy in manufacturing the light bulb is not subject to an ECS. While the consumer understands the energy consumption of the light bulb, they appear to have no way of judging the environmental impact of an FSD. This is open to potential distortions and unjustified ECS implying impact reducing, while it may be impact increasing (Morris, J., 1997) (Minneti, J. J., 2010).

Since 2007, homes in the UK have been rated for energy and $\mathrm{CO}_{2}$ impact (see Figure 2.5 below, left). In 1992, the EU Directive 92/75/EC was established as an energy 
consumption-labelling scheme for electrical items such as washing machines (see Figure 2.5 below, middle). These types of labels are seen in buildings, on home appliances and on cars (see Figure 2.5 below, right).
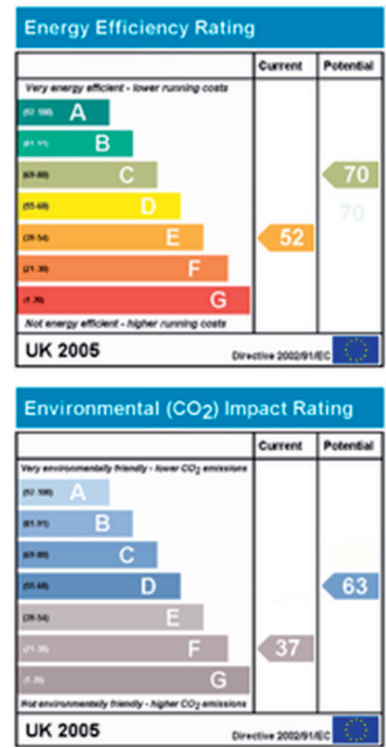

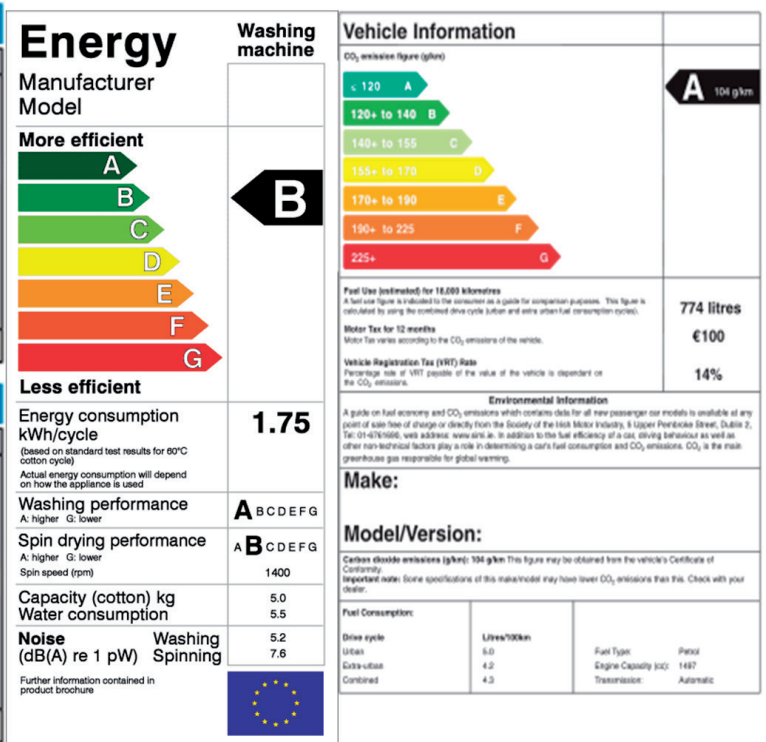

Figure 2.5: Banded Scale Labels for Energy and $\mathrm{CO}_{2}$ Emission

This type of claim statement is accepted by consumers (Horne, R. E., 2009) and is easily understood. Paying attention to these claims has a direct impact on the cost of owning the building, fridge or car, so it is of direct importance to the consumer's purchasing decision. Studies show a significant willingness to pay for A-labelled energy efficient products (Sammer K., et al., 2006). This would imply understanding and trust by the consumer in this comparative banded scale label system due to their acceptance to pay more for a high scoring product.

The above rating bands had to be increased in 2010 to cover $\mathrm{A}+\mathrm{A}++$ and $\mathrm{A}+++$, due to ever more efficient appliances.

\subsection{Comparative Banded Scale for FSD}

The comparative banded scale approach presented in the previous subchapter gives a frame of reference in which to judge product related emissions. Part of the central research question asks if a 'best-in-class' approach or product sector banded approach that provides a 'traffic light' or A-G rating system as per the above can be developed for products such as FSD? This would provide context to a comparative based claim, if a claim is made, and would give an insight into the relative environmental load of the item. 
Alternatively, in a critique of the EU Flower eco-label by Horne (Horne, R., 2009), it was cited that "the lack of a 'star-rating' type differentiation of products constitutes a key weakness". Support for a star based approach is also cited in the study of Larson (Larson, J., et al., 2011). In Egan, C. (2001), it specifically states that "[the] star graphic [was] considered consumer-friendly because it was simple to understand and most consumers were already familiar with the concept of using stars to connote performance" (p. 6). Could a star based comparative ECS system be developed for FSD?

The above emission labels are based on use phase energy and $\mathrm{CO}_{2}$ emissions only. However, FSD are items of embodied environmental impacts for which a life cycle assessment (LCA) approach should be taken (Minneti, J. J., 2010, p. 8). In accordance with ISO:14044, the formulation of a subjective weighted single figure based on LCA impact data is not permitted. This makes sense as, for example, no one person can give more weight to the impact of eutrophication over acidification, or marine toxicity over freshwater toxicity. This is partly an issue of geographic location of the consumer; the commissioner of the label cannot account for all the geographic locations in which their product is sold.

The other challenge is that life cycle impact assessment (LCIA) data are directional indicators; they do not quantify actual environmental effects (Owens, J.W., 1997). As such, these directional indicators are useful in differentiating between products; however, when they are weighted to produce a single figure result, one could question the validity of that result (Bare, J.C., et al., 2000). These directional indicators are referred to as having a relatively good level of certainty whereas the weighted end point modelling is seen as having "a much higher uncertainty" (Bare, J.C., et al., 2000, p. 321). There is no one correct method for weighting and nor will there likely be a generally accepted method (Huppes, G., et al., 2012). As stated in Finnveden, G. 1999, "The major conclusion is that none of the presently available methods can be recommended for use as an LCA valuation (weighting) method today".

A solution might be to choose a single impact that the consumer understands best and use that to form the scale within the bands. However, the use of a single environmental impact is seen as undesirable (Laurent, A., et al., 2012), (Gaussin, M., et al., 2013). It is also cited in Morris 1997 that no single measure of environmental quality can exist (Morris, J., 1997).

If one is not permitted to weight different impacts within a single figure or use only one pre-agreed impact, this renders the scaling of a band system impossible.

A further significant hindrance to ECS development would appear to be the difficulty in finding a compromise between economic feasibility and the scientific and methodological rigour which are indispensable to its credibility (Lavallée, S., et al., 2004).

It is also cited in Morris 1997 (p. 49) that "Experts charged with the task of developing an ecolabelling scheme ... are likely to encounter a number of somewhat intractable problems: 
they will be unable to:

1. rationally select product categories

2. rationally set product-category boundaries

3. take into consideration all the physical effects which a product has on the environment during its life cycle

4. accurately estimate the impact of these effects

5. continuously update the ecolabel product-selection criteria

It should be stressed that these are not merely "technical" problems; they cannot be resolved or avoided."

This raises the question as to what extent these challenges can be addressed for FSD items that require no use-phase energy input. Hence the use-phase can be discounted from the life cycle, leaving the part of the life cycle that is more likely to be easier to define. To what level of accuracy do these challenges need to be addressed? It could be that these somewhat intractable problems are a reason not to attempt to establish a comparative quantitative environmental claim.

Controlling Type II labels in the same way as Type I labels, with third party verification, could reduce the use of potentially inane or misinforming claim statements (OECD, 1997).

\subsection{Initial Goal and Scope of a Comparative Product Study}

Reference is made to the use of LCA within this study. By starting with the identification of the decisions needing to be addressed and determining the information required to make these decisions, this will aid in understanding if LCA is the most relevant tool to address them.

The decisions required within this study are derived from the determination and demonstration of environmental preferability of a product. This may require the use of LCA, depending on the sensitivity of the products being compared. It may be possible that a comparison does not require the use of LCA if the product category contains products with very evident differences between them.

The goal definition determines the intended use of the study and, by association, the type of analysis required to achieve the goal. The scope describes the system to be studied, the quantity of information to be collected and the associated level of detail and quality (Weitz, K., et al., 1999).

This reference to the level of detail at this preliminary stage may be subject to reconsideration at a later stage if it is discovered that the sensitivity of the category of products being studied in a comparative LCA is high. 


\subsection{FSD Stakeholders}

"Like water and oil, competition and cooperation do not mix" (Gomes-Casseres, 1996, pp. 70-71).

The Food Service business is highly competitive (Peter Jones, at al., 1994). The FSD business is also cited as highly competitive (Olsson, A., et al., 2004) and hence competing stakeholders in a comparative claim may be uncooperative.

While stakeholder engagement is discussed in ISO standards for environmental LCA, practitioners typically do not have the requisite training to identify affected parties and elicit the relevant value preferences (Wender B.A., et al., 2014).

If stakeholders were identified, they may still refuse to cooperate as many will likely be distributors, due to the fragmented and logistic nature of the Food Service market (O/sson, A., et al. 2004).

It could be concluded that stakeholder involvement of competitors in the development of a comparative based environmental claim may be unlikely.

It could be necessary within this study to establish to what degree the lack of stakeholder input is important within a comparative product study of the type referenced within this study. This may again depend on the sensitivity of the products within any given product category.

\subsubsection{Stakeholders in Practice}

To better understand the theoretical approach, an attempt has been made to obtain data from traders of FSD. In order to identify the chance of poor or no stakeholder involvement in cooperating in the development of a comparative ECS, a questionnaire was completed by the purchasers of five major traders of FSD in the Netherlands (Appendix B).

All five purchasers stated that the FSD business was highly competitive with the expectation that no competing FSD trader would likely cooperate with a comparative environmental claim study.

It was cited in Chapter 1 that information such as country of origin and material composition of the FSD article may be important to identify in developing a comparative ECS. Hence, interview questions were also asked related to these two points, the major conclusions being as follows:

\section{Country of Origin}

Own Traded FSD - When products are purchased direct from manufacturers, the source is obviously known. The source of raw materials or components within the FSD may not be known. Where the source is less likely to be known is when purchasing FSD from a trader. 
Competitors' FSD - This is generally more difficult to establish as the interviewees' competitors are unlikely to reveal their source. In some cases, distinguishing factors related to the product may give away the source.

\section{Material composition}

Own Traded FSD - Knowing the true material composition of a product is seen as highly unlikely and difficult to identify. Manufacturers refer to "company secrets" as a reason to not disclose the material composition. Manufacturers who do supply a list of ingredients do exist but the validation of the list is unlikely. Traders are referred to as unlikely to know or expose the composition of their product.

Competitors' FSD - It is stated as highly unlikely that a competitor would reveal their FSD material composition.

\subsection{Chapter 2 Conclusions}

FSD are significant in terms of their hygienic benefits, convenience, commercial value and resource size. They are being questioned in environmental terms due to their throw-away or disposable nature and are commonly associated with environmental claims that often appear inane or misleading.

A comparative claim such as the EU Directive 92/75/EC energy-labelling scheme is cited as providing a contextual relevance that is understandable to consumers. If such a comparative ECS is to be studied for application to FSD, there may be significant challenges as FSD are derived from a variety of competing sources and made of a wide range of materials and composites, involving a wide range of conversion processes, to perform a like functionality service. It was also cited as to whether it would be possible to rationally select product categories for comparison.

Energy labels only consider use phase energy which is not applicable to FSD. The impacts of FSD are embodied and cited as needing to cover more than a single impact factor. While this might imply impact weighting, LCIA are directional indicators and useful in differentiating between products; however, when they are weighted to produce a single figure result, one could question the validity of that result. Such as is the case for weighted end point modelling which is seen as having "a much higher uncertainty". There appears to be no one right method for weighting and nor will there likely be a generally accepted method.

As can be concluded from the considerable competition in the sector, and as seen in practice, it is also questionable as to whether stakeholder cooperation can be expected from the FSD sector, without which it could be seen to be difficult to identify the product economic inventory input to the LCA required for a comparative ECS. 
The range and complexity of issues that the study will have to engage with are a highly competitive sector with little likely stakeholder cooperation involving significant consideration as to the functional specification definition, plus a wide range of materials, processes and sources.

Chapter 3 introduces LCA in accordance with Part 1 (Describing the product, LCA, Comparative ECS and Product Economic Inventory) and further addresses factors that need to be considered in developing a method. 


\section{PART 1}

\section{Chapter 3}

Life Cycle Assessment (LCA) 
FSD are thin walled articles made from different materials originating from many different production sites as shown in Chapter 2. To be able to execute an LCA on such an article, the LCA input has to be known. This chapter addresses LCA from this point of view. It also forms part of the central research question "Is it possible to develop a method to optimize the quality of product economic inventory LCA input data, in support of product LCA based comparative claims, in the presence and absence of stakeholder cooperation?" and is the LCA description defined in Part 1 of the study.

While the primary focus of this study is to identify a possible method for establishing objective LCA input product economic inventory data in the absence of stakeholder input, it is important to reflect on LCA itself, as there are factors within LCA that can lead to differences in outcome.

This chapter will address the definition, a short historical view, procedure and uncertainties surrounding LCA. While LCA is a well-established method, it is important to identify that the method can produce different results for the same product or process; the reasoning therefore needs to be understood in light of the subject of this study.

\subsection{Definition of Life Cycle Assessment}

"Life Cycle Assessment is a tool to assess the environmental impacts and resources used throughout a product's life cycle, i.e., from raw material acquisition, via production and use phases, to waste management" (Finnveden, G., et al., 2009).

LCA is a method that quantifies environmental stressors, such as resource use and emissions, that occur over the life cycle of anthropogenic systems and translates these stressors into metrics of environmental interferences for a number of mutually exclusive and collectively exhaustive "impact categories", such as climate change, eutrophication, and eco-toxicity (Bjorn, A., et al., 2015, p. vii).

\subsection{The History of Life Cycle Assessment}

The predecessors of LCA were energy analyses which started to appear in the 1970s. They were predominately focused on inventorying energy use, resources, emissions, and creation of waste (Baumann, H., \& Tillman, A. M., 2004), (Guinée, J. B., \& Heijungs, R., 2011).

In the 1980s, LCA started developing into the form currently used, with the development of impact assessment methods which were introduced with the objective of aggregating inventory data into classes (Habersatter, K., \& Widmer, F., 1991). Thereafter, impact assessment methods started to focus on understanding the implications of the inventory data on the environment. Characterization factors then evolved based on scientific models 
to estimate the impact of substances along their impact pathways, such as the CML method (Heijungs, R., at al., 1992).

The 1990s also saw the development of standardization and harmonization of the framework, terminology and methodology relating to LCA (Guinée, J. B., et al., 2010), with the Society of Environmental Toxicology and Chemistry (SETAC) harmonizing the framework and methodological part of LCA (Klöpffer, W., 2006) and the International Organization for Standardization (ISO) focusing on the standardization of approach and procedures for LCA, resulting in two international standards: ISO 14040 and 14044 (ISO,2006a, b).

Since the 1990s, LCA has seen an exponential growth in articles, studies (Guinée, J. B., at al., 2010) (Hou, Q., et al., 2015) and LCA approaches, resulting in a range of different methods (Guinée, J. B., et al., 2010).

Today, LCA is a commonly used tool in academia, industry and in policy, whose development and further use is encouraged by the EU and UNEP.

\subsection{Life Cycle Assessment Standardized Procedure}

A description of the standardized ISO LCA procedure is given to define the framework and the four stages within an LCA study. The ISO standards provide guidance on procedures, but not on the method required for these procedural steps to be taken.

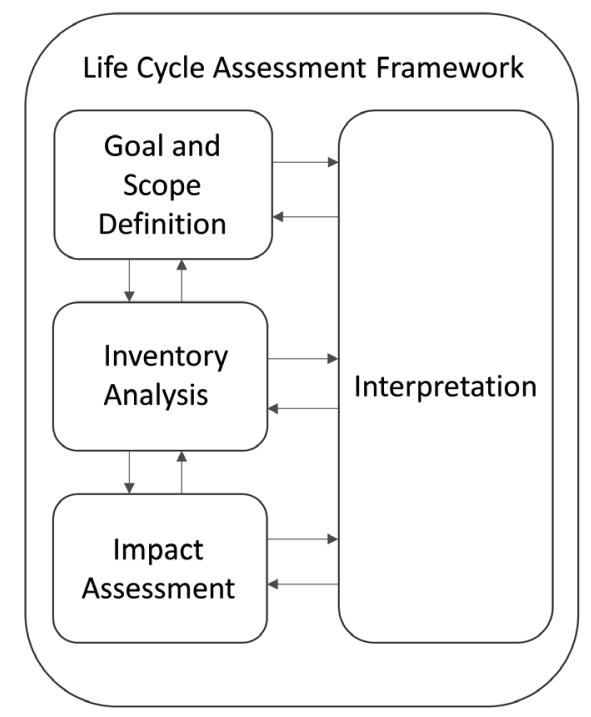

Figure 3.1: ISO 14040 (2006) LCA Framework and the Links with the Four Stages 
An ISO standardized LCA consists of four stages as follows:

\section{Goal and Scope Stage}

The first stage is the definition of the Goal and Scope. This defines the purpose of the study and how it will be performed.

1. The Goal definition describes the objective of the study, the intended use of the results, and the audience.

2. The Scope definition describes the methodological approach to be used within the study, the definition of the product under study, and the system boundaries of that studied product system. The Scope defines the methodological framework for the next two stages, these being the life cycle inventory analysis and impact assessment stages.

\section{Inventory Analysis}

In the Inventory Analysis stage, the processes within the product system are studied with the objective of quantifying the input and output data for each process, this being the inventory data.

1. Economic inventory data include the amount of resources, materials and energy needed to manufacture a product.

2. Environmental inventory data include all extracted natural resources which are input into the process and all emissions and waste released or output to the environment.

Within this study, the term "product inventory data" will largely relate to the product economic inventory data as is defined in point 1. above. This is typically the product inventory data that would have been sourced from the stakeholders should they have been present and cooperative.

\section{Impact Assessment}

At the Impact Assessment stage, the above defined Inventory data is converted into data related to their contribution to environmental impact in the chosen, scope defined, impact categories.

1. Classification - assigns the environmental inventory data to the selected impact categories.

2. Characterization - calculates the contribution of each environmental input or output to an impact category, based on characterization models.

\section{Interpretation}

The Interpretation stage involves evaluating the inventory data and impact results from the previous stages as defined in the goal and scope, drawing conclusions and recommendations.

It also addresses the reliability of the LCA results. Sensitivity and uncertainty analysis is introduced. 
While the ISO standard provides detailed guidance on procedures, it does not define the LCA methods to be used, leaving the LCA operative to choose from a range of methodological approaches. Some national standards and guidelines, with their own interpretation of approach and method, provide methodological guidance (Baumann, H., \& Tillman, A. M., 2004), (Sonnemann, G., et al., 2011), (Guinée, J. B., et al., 2002).

The ambiguity relating to the ISO LCA standards is a subject of various papers (Ekvall, T., et al., 2001), (Guinée, J. B., et al., 2010), (Weidema, B., 2014), (Zamagni, A., et al., 2008). This is important as the standardization of LCA has not led to a situation in which study results for the same product are always identical; in many cases they can be different or conflicting (Finnveden, G., \& Ekvall, T. 1998), (Lazarevic, D., 2015), (von Falkenstein, et al., 2010), (Weiss, M., et al., 2012), (Wenzel, H., et al., 2006). These differences in LCA results for the same product can be related to uncertainties in data, methodological choices and assumptions (Brandão, M., et al., 2012).

However, when used to compare different products of like functionality, LCA results require to be robust and trustworthy (Finnveden, G., et al., 1998), (Geisler, G., et al., 2005), (Guinée, J., et al., 2002), (Ingwersen, W. W., et al., 2012).

While this study researches possibilities to develop a method for increasing the accuracy and objectiveness of the product economic inventory data input into LCA in the absence of stakeholders, some sources mention differences in the outcome of studies if items are compared. This raises questions as to the use of LCA methods. More attention will be paid to this in the next paragraph.

\subsection{LCA - Uncertainties and Factors influencing their Result}

Due to the effect of the influence of LCA procedural and choice factors on the results of LCA studies, these are considered in the following subchapters.

\subsubsection{Impact Assessment Method}

Of initial consideration is the choice of impact assessment method as this has influence over the results of an LCA study (Dreyer, L. C., et al., 2003).

Commonly used impact assessment methods are CML2001 (Guinée, J.B., et al., 2002), Eco-indicator (Goedkoop, M., et al., 2001), ReCiPe (Goedkoop, M., et al., 2009), Impact 2002+ (Jolliet et al., 2003), and ILCD Midpoint 2011+ (EC-JRC, 2010).

In comparing products, it would be appropriate to use the same impact assessment method. An FSD product that is made using 100\% PP, compared to one that is 50\% PP and $50 \% \mathrm{CaCO}_{3}$, will produce a different result in the outcome of both products regardless 
of the method. Were a large number of like functionality products to be compared, their relative position regarding the mean impact may differ across different methodologies.

Without stakeholder input it can be hard to know what the material is or what the additives or fillers like $\mathrm{CaCO}_{3}$ are. The question this raises is if this will have an influence on the outcome of the products. If the weight of the two PP products in question is the same and if the plastic is recognized as PP, a researcher may feel that comparing is not worthwhile. It may be that a difference in product functionality could provide insight, for example if one item systematically fails where the other does not. This material consideration needs addressing.

\subsubsection{Weighting}

In LCA studies that require a single figure result derived from trade-offs and aggregation across LCIA impacts, weighting techniques are adopted (Bare, J. C., et al., 2000). LCIA impact, midpoint, indicators are considered to be of lower uncertainty than the endpoint indicators common to LCA. The approach to aggregation and the trade-off choices and methodologies, in deriving a single figure result to an LCA study, will impact the result between these LCA approaches.

\subsubsection{Allocation}

A further consideration relates to the allocation of environmental burden when a process produces multiple products, a common problem in LCA (Reap, J., et al., 2008), (Russell, A., et al., 2005).

Allocation is of concern when accounting for recycling, which is both a materials production process as well as a waste management option. A range of methods regarding the allocation of burden in recycling exists (Ekvall, T., et al., 2001), (Ekvall, T., et al., 1997), (Guinée, J. B., et al., 2002), (Ligthart, T. N., et al., 2012), (Newell, S. A., et al., 1998).

Their application can also result in differences in LCA results for the same product (Azapagic, A., et al., 1999), (Cederstrand, P., et al., 2014), (Ekvall, T., et al., 2001), (Weidema, B. P., et al., 2010).

\subsubsection{Uncertainty}

Uncertainty is inherent in LCA studies and must also be considered. Uncertainty should be explicitly and transparently addressed in LCA studies, especially if they are to inform decision makers (Bennett, N. D., et al., 2013), (Jakeman, A. J., et al., 2006).

In the ISO 14044 procedure (ISO, 2006b), it is stated that uncertainty analysis must be adopted, being seen as integral to LCA (Ciroth, A., et al., 2004), (Finnveden, G., et al., 2009), (Heijungs, R., et al., 2004), (Notten, P., et al., 2003). 


\subsubsection{Process Datasets}

An increasing number of datasets are becoming available covering the same or similar processes, such as those available from Ecoinvent. LCA results can differ based on the choice of dataset adopted for a process, this being addressed using sensitivity analysis (Peereboom, E. C., et al., 1998).

\subsection{LCA - Streamlined LCA}

A concern as relates to the use of LCA is the associated cost in terms of time and money, with some even questioning that the established LCA methodology may be "beyond the reach of most potential users" (Weitz, K., et al., 1999). This has led to the study of streamlined LCA and their approach and value. Reference to streamlined LCA will be made within this study as relates to the collection of product inventory data.

\subsection{Chapter 3 Conclusions}

Whether an LCA study is made with or without stakeholder cooperation, with or without specific data, the implication regarding choices of impact assessment method, allocation, uncertainties and datasets needs to be considered, as they can influence the relative results.

While further consideration will be made regarding the implications of these choices later in the study, the primary focus of this study is to identify a method to increase the objectivity of comparative product economic inventory LCA input data in the absence of stakeholder cooperation. All testing of any eventual identified LCA input methodology will be based on a single consistent LCA approach.

Chapter 4 introduces and researches comparative ECS as relates to FSD and the development of Part 1 (Describing the product, LCA, Comparative ECS and Product Economic Inventory") of the study. 


\section{Chapter 4}

\section{Comparative Environmental Claim Statements}




\subsection{Introduction}

Many FSD display Environmental Claim Statements (ECS). Chapter 2 presented an overview of some of them found in the market. Reference was made to the EU Directive 92/75/EC energy consumption-labelling scheme. One question being - can such a comparative ECS for FSD based on LCA be developed? These types of comparative claims have the potential to be useful in terms of defining the relative environmental merits of one product over another but there must be surety that the presented claim is correct.

As stated in Chapter 1 in comparing the relative environmental performance of different like functionality products, LCA based quantitative environmental claims, such as Environmental Product Declarations (EPD) and the EU Product Environmental Footprint (PEF), require common rules in order for claims to be comparable within a category. These Product Category Rules (PCR), as defined in the ISO 14025 standard, define how life cycle environmental impacts should be developed for products within a given category.

However, there is no single international organization that oversees the development of PCR (Ingwersen, W. W., \& Stevenson, M. J., 2012).

This chapter will examine how these comparative claim schemes are established, as well as their specific rules as relates to product economic inventory input to LCA, and the identification of the challenges associated with their use as relates to a study of FSD. This chapter further contributes to the central research question (CRQ): Is it possible to develop a method to optimize the quality of product economic inventory LCA input data, in support of product LCA based comparative claims, in the presence and absence of stakeholder cooperation? This is found in Part 1 (Describing the product, LCA, Comparative ECS and Product Economic Inventory) of the study related to describing comparative ECS.

\subsection{Rules governing the Design of Comparative ECS}

A starting point to making comparisons between items is that they are comparable. Can a metal reusable spoon be directly compared with a single use wooden one and is it possible to compare a single use wooden one with a single use polystyrene one? The goal of a study, based on the decisions required to be addressed by the commissioner of the study, will define what is to be compared, this being either a functional description (a vessel for the consumption of $200 \mathrm{ml}$ of beer) or a product description (a knife).

In this subchapter, attention will be paid to the following comparative claim schemes:

1. EU Product Environmental Footprint (PEF), specifically the PEF category rules (PEFCR)

2. The International Environmental Product Declaration (EPD) 
Reference will be made to how the ISO Standard (specifically ISO 14025:2006) might be used to guide the establishment of comparative claims as relates to both schemes.

Can the PEFCR, EPD and the ISO 14025 Standard be used as a guide to establishing comparative claims and to what extent?

The following subchapters will review ISO, PEFCR and EPD rules, respectively, focusing on aspects that could pose challenges with regard to FSD and their associated comparative claims. These issues will subsequently be grouped under seven broader headings in Chapter 4.2.4, through which they can be taken into account in the process of research into the possibility and eventual consequences of developing an LCA based comparative ECS.

\subsubsection{ISO 14025:2006}

The ISO 14025 Standard relates to Type III environmental claims based on the quantified life cycle environmental impacts of a product so as to enable comparison between products of a like functionality (ISO, E. (2006). 14025: 2010. Environmental labels and declarations-Type III environmental declarations-Principles and procedures (ISO 14025: 2006)). The Standard sets out the principles and procedures for developing Type III labels and establishes the use of LCA following the ISO 14040 series for such claims. The Standard is regularly referred to within both the PEFCR and EDP.

The Standard requires the involvement of a program operator and various relevant and interested parties to develop the Type III approach. While this would be desired, it is imagined that such level of cooperation might not always be possible (Ingwersen, W.W., et al., 2011, p. 106). It could also be said that such cooperation could involve a very large number of parties.

Key challenges posed under different articles of the Standard are identified as follows:

ISO-1/p. 5 Art.5.5 - the development of the claim should be an "open, participatory consultation with interested parties".

ISO-2/p. 5 Art.5.6 - information provided for comparison shall be transparent.

This must apply alongside rules for data confidentiality, and this might be enabled through the statement in Article 8.3 that the Type III "declaration typically only provides data aggregated over all relevant stages of the life cycle".

ISO-3/p. 6 Art.5.8 - requires technical credibility whilst ensuring cost-effectiveness within the process of applying the Standard.

ISO-4/p. 10 Art.6.7.2 a) - the function, technical performance and use of comparative products must be identical. 
ISO-5/p. 10 Art.6.7.2 c) - the methods of data collection, calculation and allocation must be equivalent.

ISO-6/p. 14 Art.7.2.2 b) - lists the following required LCA impact indicators:

1. Climate change

2. Depletion of stratospheric ozone layer

3. Acidification of land and water sources

4. Eutrophication

5. Formation of photochemical oxidants

6. Depletion of fossil energy resources

7. Depletion of mineral resources

Reference is also made to the use of toxicity indicators.

\subsubsection{PEFCR}

The Product Environmental Footprint or PEF is an EU initiative seeking to reduce the environmental impact of products based on the impact of their supply chain activities.

Some important issues related to FSD are taken out and presented here.

PEF-1/p. 9 - "involvement of selected parties". PEFCR shall "include consultation with relevant stakeholders' parties". Hence, cooperation is required between competing parties in a product comparative study.

PEF-2/p. 13 - "identification of the product category for which a PCR is to be developed, including a description of, for example, the product's function(s), technical performance...". As with the above Standard, this would suggest that research must be carried out to gain insight into what is required to do this, so that products can be compared with each other for their compliance to a category for FSD.

PEF-3/p. 13 - States that if PCR are available for other schemes, these could be used as a basis for developing a PEFCR. The EPD database of PCR does not include products that could reasonably be called FSD (environdec website, accessed 01/12/2015).

PEF-4/p. 14 - PEFCR structure is based on the Classification of Products by Activity (CPA), basically the statistical classification NACE codes. There is no single statistical classification code for FSD which could be used to define their category. PEFCR do accept the use of alternative CPA across products of like functionality derived from different production routes.

PEF-5/p. 20 - Specific or generic data can be used in a PEF study, referred to as foreground and background processes. In a comparative study for which there is no cooperation 
between the parties, it could be said that only generic data could be used in order to be fair. On page 27, it is stated that if a company does not have access to specific data then generic data will typically be used. It is stated that it is good practice to access data collected directly from suppliers; however, this is unlikely to be possible in a study in which there is no cooperation between the parties.

PEF-6/p. 20 - PEFCR implies the use of a cradle-to-grave study with any deviation from this approach being reported.

PEF-7/p. 21 - The selection of impact indicator should be comprehensive and cover all relevant environmental issues related to the FSDs supply chain. However, a default list of impact indicators is provided (p. 22) and any deviation from the list is to be reported. The list covers:

1. Climate Change

2. Ozone Depletion

3. Ecotoxicity for aquatic freshwater (sea water is also advised (p. 23))

4. Human Toxicity cancer effects

5. Human Toxicity non-cancer effects

6. Particulate Matter/Respiratory Inorganics

7. Ionizing Radiation

8. Photochemical Ozone Formation

9. Acidification

10. Eutrophication Terrestrial

11. Eutrophication Aquatic

12. Resource Depletion Water

13. Resource Depletion Mineral, Fossil

14. Land Transformation

The above impact indicators cover those required by the ISO Standard, additionally they list human toxicity, particulate matter, ionizing radiation and land transformation.

PEF-8/p. 25 - reference is made to listing "technical parameters" in assessing the products under study to permit comparison.

PEF-9/p. 27 - provides a tip regarding the documentation of data collected to aid the revising of future product inventories and to reflect changes in production practices. In a non-cooperative study, this would involve the complete reappraisal of products from the market in order to detect changes in their functionality against the Functional Unit definition, as well as a complete materials composition analysis of the product.

PEF-10/p. 28 - states that all resource use shall be included in the study. It is also stated that any exclusion of supply chain stages shall be explicitly justified. Material component 
analysis identifies the resources in use and their associated conversion stages in the supply chain. Specific reference is made to "Raw material acquisition and pre-processing" on page 29. A list of substance activities and processes is required for PEFCR as mentioned on page 30 .

In the page 57 data collection box, it is requested that data shall be collected on all foreground activities and the data should include all known inputs. On page 58 it states that "it is important to express data in terms of constituent substances" and goes on to use NPK fertilizer as an example in which it "should be disaggregated and classified according to its N, P and K fractions, because each constituent element will contribute to different EF (environmental footprint) impact categories".

PEF-11/p. 35 - refers to energy mix which is a significant factor as regards the conversion processes. It is stated that "if supplier-specific data is not available, country specific consumption-mix data shall be used of the country in which the life cycle stage occurs". This implies knowledge of the country of origin $(\mathrm{CoO})$ of the product and its production stages.

PEF-12/p. 48 - PEF data should be technologically and geographically representative. The former would suggest strong knowledge of the components in the product and their associated conversion processes. The latter would indicate the need to understand the $\mathrm{CoO}$ of the various components and processes.

PEF-13/p. 61 - weighting is permitted as a tool for the interpretation and communication of the study results.

PEF-14/p. 64 - PEFCR shall describe the uncertainties common to the product category. "Quantitative uncertainty analysis may be calculated for variances associated with the resource profile".

PEF-15/p. 70 - covers the review process in which the reviewer must have knowledge of relevant technologies and processes as relates to the products under study. This qualification of knowledge of these technologies is assigned according to the classification of CPA/NACE codes (Classification of Products by Activity/Nomenclature statistique des activités économiques dans la Communauté Européenne). With such a wide range of materials, technologies and $\mathrm{CoO}$ involved in FSD, spread over a wide range of NACE codes, a demanding level of knowledge is required.

\subsubsection{EPD}

The objective of the International Environmental Product Declaration System is to help support parties in the reporting of the environmental performance of their products for the global market. The EPD focuses on a cooperative approach between the stakeholders. 
The following eight issues are particularly important as related to FSD:

EPD-1/p. 13 Art.3.1 - UN CPC (Central Product Classification) is used to define the scope of the PCR. However, the scope is also stated as being established based on Functional Unit (FU) definition.

EPD-2/p. 14 Art.3.3 - states that a PCR should define the product functional and technical performance plus the materials and substances in the product content. Page 18 of Article 4.3 states that an EPD requires "a technical description of the product in terms of functional characteristics, main product components and/or materials". Page 19 of Article 4.4 relates to contents declaration and as such requires a list of the product's materials and chemical substances content in quantitative terms "related to their weight on their functional/declared unit or percentage weight".

EPD-3/p. 15 Art.3.5 - states that transparency is one of the main principles of the EPD system. On page 19 of Article 4.4, reference is made to exemptions for proprietary materials and substances. On page 29 of Article 5.1.3, specific reference is made to data confidentiality and the fact it is not made public as the declaration typically provides data aggregated over the full life cycle.

EPD-4/p. 23 Art.4.5.3 - a set of default emissions based impact indicator categories are given:

1. Emissions of greenhouse gases

2. Emissions of acidifying gases

3. Emissions of oxygen depleting substances to water

4. Emissions of gases contributing to ground-level ozone

Reference is also made to the use of the following impact categories:

1. Emissions of ozone-depleting gases

2. Land use and land use change

3. Abiotic resource depletion

Other impact categories can be used as is environmentally relevant to the product category.

EPD-5/p. 28 Art.5.1 - refers to studies of a large variety of products and the unlikely existence of background data and assessments. In this case, any sampling methods developed should be clearly documented for verification.

EPD-6/p. 31 Art.5.2.1.2 - refers to the optional use of sensitivity analysis.

EPD-7/p. 36 Art.5.5.1 - refers to the need for verifiers to have good process and product knowledge. 
EPD-8/p. 42 Art.A.5 - refers to the use of specific and generic data, with specific data being preferred. Specific data being mandatory for the core activity with generic data being acceptable for upstream and downstream processes. Specific data collection being a challenge in the absence of stakeholder cooperation.

\subsubsection{Conclusion from PEFCR, EPD and ISO 14025 as relates to LCA Input}

The above study of the mix of duplication and complication arising across the ISO, PEF and EPD specifications highlights significant factors as relates to the formulation of product economic inventory input data for an LCA to be used for a comparative ECS, these being as follows:

1. Cooperation between stakeholders is necessary. The FSD sector is a significantly diverse and large business sector supplying items of very low value, which could impede cooperation.

2. The function, technical performance and use of products to be compared must be identical. This would imply research such as the testing of several functional aspects related to the functional specification of the item, for example holding the content, being able to walk with it, withstanding a certain temperature, which can be translated into physical, tactile and mechanical properties of the products, in order to identify their comparability to qualify for the defined category.

3. The material composition of all products will need to be identified. Material component analysis identifies the resources in use and their likely associated conversion process stages in the product life cycle.

4. Country generic energy mix approach is permitted. In such a global sector, with potential non-cooperation and conversion stages that may constitute the major impact of a product, the identification of the $\mathrm{CoO}$ of the conversion of the product becomes important.

5. Transparency of data is imperative to a credible comparative ECS. If there is no cooperation between the stakeholders, no information will be forthcoming. If materials analysis is used to define the components in a series of like functionality products, this could lead to intellectual property concerns.

6. Reference is made to the use of generic or secondary impact indicator data. In the event of stakeholder non-cooperation, the use of generic data may be the only route to a comparative ECS.

7. Product/sector knowledge is stressed as a requirement of parties involved in vetting the comparative ECS approach. With the extent of the mix of materials, processes and likely $\mathrm{CoO}$, it could prove a challenge to identify such a party. 


\subsubsection{Observations Derived from the Conclusions in Chapter 4.2.4}

If the use of generic data is acceptable in a study to support a comparative ECS but there is no stakeholder based product inventory data, should this be a reason not to develop a comparative ECS for FSD? Or to accept the development of a comparative ECS of limited credibility and value due to the use of assumptions made in the absence of stakeholder data? If stakeholder cooperation is unavailable, could it be possible to develop other solutions to establish this missing stakeholder product data? Could objective technical solutions be found to generate this missing stakeholder product data?

If so, these technical solutions would appear to have to address the following points derived from the above summary of the PEFCR, EPD and ISO 14025:

1. the product category definition and qualification which would include the definition of the functional specification to be compared and the final functional unit of the study,

2. the materials composition of the qualified products which could also aid in further identifying the production processes the FSD is subjected to,

3. their country of origin, to aid in national energy mix choices and related transport types and distances.

Each of the above three points will be researched, each within their own chapter, notably Chapters 7,8 and 9 .

Additional to this technical approach, it would appear evident that the operative carrying out this technically based study would require to have technologically relevant knowledge as relates to FSD, in order to correctly identify the product inventory and interpret the results of such a study. The extent of the importance of this point may become evident in the following chapters addressing a technical solution to establish the missing stakeholder data.

\subsection{Resulting Challenges to Address in Developing a Comparative ECS}

The following subchapters will consider the challenges associated with the development of LCA input product economic inventory data for a comparative ECS in the case that there is non-cooperation between the stakeholders and a single party chooses to develop a comparative ECS. It is cited that the greatest challenge in creating applicable PCR is in convening a representative group of stakeholders (Ingwersen, W.W., et al., 2011, p. 106) and this could be the case for such a competitive and multiple source product group such as FSD.

This point is further addressed in Finkbeiner, M., 2014, in which international cooperation between stakeholders is questioned, this being a potential concern as FSD are sourced globally (Finkbeiner, M., 2014). It is further cited that competitors may wish to seek competitive advantage from an environmental action which may lead to a lack of cooperation (Shrikanth, R., et al., 2012). 


\subsubsection{Comparison and Functional Unit}

In order to compare products of like functionality, they must first be categorized. Rules defining which category a product qualifies for must define those attributes describing the category and how the category is distinctive from other similar categories (Sujan, 1987).

A comparative ECS should seek to establish a representative category of like functionality product options from the target market. Any method developed to identify a representative category would need to be defendable as the resultant category may be contentious given the potential exclusion, or inclusion, of competing parties.

The development of the rules associated with this category definition will define the Functional Unit (FU) of the LCA. If products were positioned within a category in a comparative ECS, the definition of these rules and the FU could have significant influence over the relative position within a category of like functionality products. As such, the development of the FU will be fully visited in Chapter 7.

With FSD being "fit-for-purpose" single-use items, issues of product quality are important (Ingwersen, W., et al., 2012). Hence, significant effort will be apportioned to defining the quality level within the product functionality rules and FU in Chapter 7.

\subsubsection{Product and Material Composition}

Once the product functionality rules and FU are established and the representative products are identified for their qualification to the category, the weight of the components within the products must be established. This process should seek to identify the material components used and hence also their associated conversion processes.

This raises the question as to whether this process should involve a purely visual identification of materials or a more studied level of identification involving instrumentation? If the latter, to what degree of depth should the identification go? This leads to the question what are the associated effects on the relative position of a product, within a category of like functionality products, in a comparative ECS based on the degree of depth of material component identification?

Chapter 8 will take an in depth view of the issues surrounding the values of materials identification.

\subsubsection{Country of Origin (CoO)}

Conversion processes typically constitute a significant portion of the environmental impact of an FSD. These processes are energy intensive and it could be said that the energy within the process is that of the country in which the process is carried out. The environmental impact of energy can vary greatly between countries, hence the need to identify the country in which the FSD's conversion processes have taken place. 
Chapter 9 will research this potentially significant challenge and the associated effects on the relative position of a product within a category of like functionality products in a comparative ECS.

\subsection{Chapter 4 Conclusions}

A description has been made of the current methods for comparative environmental claim statements (ECS).

Factors have been identified that need to be addressed in developing the researched method.

It can be concluded that PEFCR, EPD and ISO 14025 are largely in line and that a greatest common factor can be determined. Three aspects came out as being of importance:

1. Definition of the Functional Unit

2. Material Composition

3. Country of Origin

Insight into the supply chain and FSD technologically relevant knowledge are critical aspects that also need consideration.

In the following chapters, these topics will be researched in greater depth:

Chapter 7 - the Functional Unit (FU) related challenges

Chapter 8 - the product Material Composition (MC) related challenges

Chapter 9 - the Country of Origin ( $\mathrm{CoO}$ ) of the conversion processes related challenges

In Chapter 11, the outcome of these chapters will be combined and tested. Research will be carried out to establish if these elements can be combined into a method in which consideration will be made regarding the required insight and knowledge in the chain.

A further factor concluded from the PEFCR, EPD and ISO 14025 review was the necessity of stakeholder cooperation in carrying out such studies. As observed in Chapter 2, this is a concern as regards FSD products. Hence, contrary to the rules of PEF and EPD, generic or secondary data will be exclusively used in this study for materials, processes, energies, transports and end-of-life scenarios.

An LCA based product scoring tool will be used that will remain constant in its generic data source and methodology while studying the impact of the sensitivity of the various product economic inventory LCA input data challenges. The research will focus on understanding the effect of product economic inventory LCA input data sensitivity on the LCA outcome. If the outcome is presented in terms of the relative position of one product 
compared to another within a comparative ECS, insight is gained into the importance of the mentioned three factors. It is not the objective of this part of the study to research the relative differences in LCA methodology, this LCA input data being derived from addressing the challenges mentioned above in Subchapter 4.3.

Chapter 5 will research the current methods of approaching product economic inventory input to LCA in the absence of stakeholders. 


\section{PART 1}

\section{Chapter 5}

\section{Sourcing and Collecting Product Life Cycle Inventory Data}


This chapter considers the current approach to the collection of product economic inventory data in the absence of stakeholders' input; this being the life cycle inventory analysis stage (Figure 3.1) of the LCA approach, in accordance with the Part 1 research "Describing the product, LCA, comparative environmental claim statements (ECS) and the product economic inventory" and research question 1a "What are the factors that need to be addressed in developing a method?".

The Life Cycle Inventory (LCI) is the LCA phase involving the compilation and quantification of inputs and outputs for a given product system throughout its life cycle. (Van Berkel, R., 2002).

"A crucial problem in the inventory analysis is ensuring the collection and use of complete and reliable data and the availability of clear explanations of applied assumptions, advantages and disadvantages, as well as caveats to satisfy transparency, acceptability and credibility criteria for such analyses." (Klöpffer, W., et al., 2007).

\subsection{Introduction}

Data collection procedure is referenced in the ISO standards as "The procedures used for data collection will vary with each unit in the different systems modelled by the LCA study. Procedures may also vary due to the composition and qualification of the participants in the study and the need to satisfy both proprietary and confidentiality requirements." (ISO (1997a), Draft International Standard 14041. ISO/TC207/SC5/WG2 N112, 1997-03-20). It could be concluded that this statement is insufficient as a guide on how to approach data inventory sourcing and collection.

As was identified in Chapter 4, stakeholder cooperation is vital when making studies of comparative product environmental impact claims, while in Chapter 2 it was cited that the FSD business is such that it is unlikely to achieve this cooperation. This lack of stakeholder input could lead to many products being unaccounted for in terms of comparative claims, which may be seen as unacceptable.

What data collection methods are currently used by parties making comparative LCA based studies in the absence of stakeholder input? It is important to research this point prior to researching the possibility of developing a method for the identification of product economic inventory LCA input data in the absence of stakeholder input.

As was identified in Chapter 4, such data is required to establish:

1. the Functional Unit and the Functional Specification compliance category rules

2. the Materials and Weights of the products for comparison

3. the Origin of the products for comparison 
In Chapter 10, consideration will be made as to the level of technologically relevant knowledge required by the LCA operative in a comparative study of FSD. This is likely to influence the operative's approach to collecting product inventory data in the absence of the stakeholder input. "LCA practitioners are often generalists and should delegate an elaboration of indicators plus quantification to specialists" (Klöpffer, W., et al., 2014).

Is it likely that there are variable approaches to the collection of product economic inventory data in the absence of stakeholder cooperation? This variance in approach could result in different input in the core product inventory analysis stage of LCA (Figure 3.1). Hence, the desired LCA inventory analysis reproducibility or repeatability could be questioned (Gaussin, M., et al., 2013). ISO 14025 cites that methods of data collection, calculation and allocation must be equivalent (ISO 14025:2006 p. 10 Art.6.7.2).

It is suggested that this lack of good data may be hampering the adoption of LCA by otherwise environmentally conscious parties (Buysse, K., et al., 2003) and the ability to compare product alternatives using LCA may be limited due to the nature of inventory data collected (Lee, S. G., et al., 2005). Low data quality can both increase the uncertainty and change the mean value (Weidema, B. P., et al., 1996).

\subsection{Method of Research}

Five approaches were taken in order to research the existing practice of LCA operatives in sourcing and collecting product inventory data when preparing a comparative claim. These are academic papers, questionnaires, interviews, web-tool research and commercial LCA tools and are taken up in the following subchapters.

\subsubsection{Scientific Research}

In Baumann, H., et al 2004, it is stated that "Data collection is one of the most time consuming activities in LCA. Yet, very little has been written about how to carry out data collection. LCA guidelines are typically concerned with what type of data to collect, thereby accidentally portraying the collection in itself as a rather unproblematic activity" (Baumann, H., et al., 2004, p. 99).

Baumann goes on to state "One problem almost inherent to LCA is that no practitioner can be a technical expert on all the different technologies represented in a life cycle", hence "practitioners may not always have access to relevant data sources" and "other people need to be asked". This may be resolved by following the advice of Klöpffer, W., et al., 2014 above and involving an expert.

Baumann cited a situation in which "no established channels to data suppliers were at hand" and proposed a variety of techniques for data sourcing of which one was "disassemble the product in order to weigh the constituent materials and components". 
Further elaboration of this disassembly type approach, as regards materials composition, is not covered in the Baumann study. Other techniques mentioned involved a varying degree of direct or indirect stakeholder involvement plus reliance on equivalent existing studies and information not subject to intellectual property constraints.

In Heijungs, R., et al., 1992, reference is made to "the process data having to be collected and entered" with no explanation of how this collection is achieved (Heijungs, R., et al., 1992).

Again, in Rebitzer, G., et al., 2004, it is cited that "Data collection and compilation are often the most work- and time-consuming steps in LCAs" (Rebitzer, G., et al., 2004), further stating that "the LCA practitioner may have little previous knowledge of the process for which data is to be compiled". While Rebitzer provides a list of challenges in sourcing inventory data, no solutions to data sourcing are proposed that do not involve stakeholder cooperation. The SETAC study into streamlined LCA further addresses the cost and time taken in compiling inventory data (Weitz, K., et al., 1999).

It should be noted that the papers by Heijungs, R., et al., 1992 and Rebitzer, G., et al., 2004 are significant guides as regards LCA. Other papers such as Guinée, J. B., et al., 1993 also provide no guidance as to how to source the inventory data (Guinée, J. B., et al., 1993). The assumption in these papers is that the inventory data is simply available, complying with the Baumann comment on data collection being portrayed as "a rather unproblematic activity".

In Baumann, H. 1998, it is cited that "strategies for data collection/search are seldom described". Baumann goes on to list the approaches to inventory data sourcing for a study in which the direct manufacturers of various comparable items were largely noncooperative, as seen below in Table 5.1.

Table 5.1: Approaches to Inventory Data Sourcing in Baumann, H., 1998

\begin{tabular}{l|c|c|c}
\hline & \multicolumn{1}{c}{ Successful } & Dead Ends & Total \\
\hline Browsing (e.g., in shops) & 1 & 1 & 2 \\
\hline Phone directory & 2 & 1 & 3 \\
\hline Experimental (e.g., weighing) & 3 & 1 & 4 \\
\hline Tip from data supplier & 7 & 1 & 8 \\
\hline Search library or WWW & 2 & no data & $(2)$ \\
\hline Tip from colleague or acquaintance & 6 & 5 & 11 \\
\hline Unknown & 1 & 1 & 2 \\
\hline
\end{tabular}

In Rubik, F., et al., 2008, reference is made to the requirement of comparable data from competitors' products, an average against which products can be benchmarked. This is seen as important to eco-design, eco-labelling and correct "green positioning". The paper cites this as being easy; however, the example given is that of a washing machine in which a radar 
map is made to cover water and energy consumption, washing performance, water discharge and ability to be dissembled. These factors are not entirely relevant to the use of items like FSD as they are items of embodied environmental impacts rather than use phase impacts.

Vigon, B. W., et al., 1993 cites "Frequently, the end user will not be able to supply specific information on inputs and outputs. However, the end user can provide data on user practices from which inputs and outputs can be derived. Generally, the end user can be the source of related information from which the energy, materials, and pollutant release inventory can be derived". In a comparative LCA for which one of the items involves a stakeholder, this stakeholder's experience regarding the item's composition may act to aid in inventory data collection for the other like functionality items. However, as Vigon 1993 states, it is possible that the end user of the study may be devoid of such data.

Van Berkel, R., 2002 cites that trade-offs are being made in terms of data coverage and quality depending on the duration of the study and the cost of data collection and collation, introducing economic constraints as relates to inventory data collection. O'Neill, T. J., 2003 specifically cites "collection of LCl data can be costly and time consuming and this fact often results in LCA studies being inadequately executed or abandoned because of inconsistent LCl data".

Weitz, K., et al., 1999 cites "review the current literature on LCA concepts and methods and then tailor those concepts or methods in some manner to fit their decision-making needs and constraints (e.g., resources, time)". Other approaches cited relate to leaving out specific LCl components, limiting raw material to a specific mass percentage such as 10\% and using surrogate data from apparently similar processes.

Jiménez-González, C., et al., 2000 cites "Patents, articles, electronic and on-line databases, industrial bulletins, and direct industrial contacts are examples of the sources of information".

Table 5.2 below lists the observations derived from the above academic papers.

Table 5.2: Product Inventory Collection Approaches in Academic Papers

\begin{tabular}{l|l}
\multicolumn{1}{c}{ Scientific Research } & \multicolumn{1}{c}{ Observations } \\
\hline Baumann, H., et al., 2004 & disassemble the product in order to weigh the constituent materials and components \\
\hline Baumann, H., 1998b & $\begin{array}{l}\text { browsing in shops, phoning and internet enquiry, weigh product parts, tips from data } \\
\text { suppliers and knowledgeable acquaintances }\end{array}$ \\
\hline Rubik, F., et al., 2008 & use-phase studies and disassembly (washing machine) \\
\hline Vigon, B. W., et al., 1993 & other stakeholders of similar products could act as a guide \\
\hline Weitz, K., et al., 1999 & $\begin{array}{l}\text { review the current literature on LCA concepts and methods and then tailor those con- } \\
\text { cepts or methods in some manner to fit their decision-making needs and constraints }\end{array}$ \\
\hline Jiménez-González, C., & $\begin{array}{l}\text { patents, articles, electronic and on-line databases, industrial bulletins, and direct } \\
\text { et al., 2000 }\end{array}$ \\
\hline
\end{tabular}




\subsubsection{Questionnaire}

A questionnaire was sent to 18 people who are known to be LCA specialists, of which ten people responded. Of those who responded, six completed the questionnaire to a level that could facilitate the research. The questionnaire and the list of specialists are available in Appendix C.

A consistent comment across all six responding parties was the fact that money has a large influence on their pursuit of product $\mathrm{LCl}$ data. This is also cited on page 6 of Article 5.8 of the ISO 14025:2006 Standard. Time is money and the collecting of product inventory data is time consuming. This implies that the more time that is available, the greater the opportunity there is for more or better data compilation.

The respondents tended to indicate that in most cases stakeholders are available and will cooperate given that they are often the commissioners of the study. Alternative or additional sources of inventory data stated were:

Table 5.3: Mentioned Alternative Sources of Inventory Data

\begin{tabular}{l|c}
\hline Mentioned alternative or additional sources of inventory data & No. of mentions \\
\hline Technical literature & 2 \\
\hline Study other similar products LCAs and public datasets & 2 \\
\hline Disassemble the product & 5 \\
\hline Visit websites selling similar products & 1 \\
\hline Visit specialized retailers selling similar products & 2 \\
\hline Make proxies based on other assumed similar products & 1 \\
\hline Contact producers of similar products & 2 \\
\hline Contact branch organization representing the product type & 1 \\
\hline Study the material code numbers and serial numbers & 1 \\
\hline Use the internet & 1 \\
\hline
\end{tabular}

The respondents also tended towards questioning comparative quantitative results when asked how accurate they believed their results to be in the absence of stakeholder input. Stating the results are often obvious and hence may not require a very deep or sophisticated LCA study. This may be the case for products of like functionality that are very different in materials, construction or design; it can be questioned if this would be the case for products that are very similar in design and apparent materials.

In general, the LCA experts seemed to be focused on studies of items, unlike FSD, for which stakeholders are involved. However, they also stated that stakeholders may not be required. Again, this may be because the items under study have an obvious result. This calls into question whether if this "lack of stakeholder" approach could be sufficient when identifying the product economic inventory data for a very similar range of FSD. 


\subsubsection{Discussions with Packaging LCA Experts}

These above results seem to be in line with a notification from a discussion held at the IAPRI (International Association of Packaging Research Institutes) Symposium in May 2017, involving four packaging LCA specialists, regarding a paper serviette that was on the table. Details of this discussion and interpretation thereof can be seen in Appendix D.

This discussion seemed to affirm the above mentioned topics from the academic paper study and the questionnaire respondents' answers. Even though the LCA specialists in this discussion were packaging experts with insights into materials and additives, it seems that inventory data is specified on basis of their current knowledge, previous projects, known similar product sources and assumptions when stakeholder data is unavailable.

\subsubsection{Web Tool Research}

A variety of open access LCA based environmental impact assessment tools are available on the internet. A study of these may contribute to further understanding of product economic inventory collection in the absence of stakeholder input. The accuracy, relevance and acceptability for use in a comparative product study have not been considered. The tools studied were those that offered some degree of free of charge access.

\section{Pack4ecodesign}

This tool is titled "Eco-design for Packaging" with a by-liner stating that it is "The Toolbox for Packaging Professionals". The site is branded with the logo of the Belgian waste organization FostPlus.

At no point in the tool is reference made to the source of the product economic inventory data. The statement "Enter into the corresponding fields the data on the main packaging..." is made, with no reference as to how to access this data. The tool begins by asking the user to click on a packaging type such as tray, box, bottle, jar, etc.

\section{LCA2go}

The LCA2go tool supports SMEs in conducting the environmental assessment of their products, based on LCA and considering their entire life cycle. The tool was developed from financing largely by the European Union.

At no point in the website is reference made to the method of sourcing the product economic inventory data. The tool provides many composite additive choices that are not identifiable when taking a purely visual product inventory identification approach, hence this web tool assumes that the SME has this information available. 


\section{OpenLCA}

OpenLCA is an open source LCA tool provided by GreenDelta and supported by numerous parties including the European Union, the US Department of Agriculture and the German Ministry of the Environment.

OpenLCA is a more complete LCA tool, unlike the above two tool examples which are more limited. The assumption at all times is that the user is already in possession of the product economic inventory data.

\subsubsection{Commercial LCA Tool Research}

With regard to the traditional commercial LCA tools, a study of their associated websites and operating instructions may contribute to a further understanding of product economic inventory collection in the absence of stakeholder input.

1. SimaPro LCA tool tutorial provides no description of how product inventory could be collected.

2. Gabi LCA tool manual provides no description of how product inventory could be collected.

The function of these commercial LCA tool manuals is to instruct the reader regarding the operation of the LCA software and not specifically in the collection of product economic inventory data.

The Ecoinvent database commonly used for generic or secondary data can, for some specific products, provide insight as to their composition. This may, or may not, correctly represent the components in a specific product of a similar type.

Some tools used by product designers also come with an LCA type feature, such as the Cambridge Engineering Selector (CES) and the SolidWorks SustainabilityXpress. This aids designers in understanding the environmental impacts of their design decisions. In this case, materials composition and processing requirements plus country of origin would be known before the product is manufactured.

\subsubsection{Further Web based General Research}

The IAPRI lists amongst its members an organization called Packaging Forensic Associates in Michigan USA, stated as being engaged in providing consulting for the analysis, design and evaluation of packaging systems. The Packaging Forensic Associates website lists all of the cases they have been involved in since 1986. The list does not mention cases involving a dispute of an environmental claim based nature. 


\subsection{Chapter 5 Conclusions}

In Baumann, H., et al., 2004, it is stated that very little has been written about how to carry out product economic inventory data collection for inclusion into an LCA study. The above research involves scientific papers, a questionnaire to LCA experts, interviews of experts and LCA tool operating manuals. In most cases it is assumed that the LCA operative will already have product economic inventory data, without stating the source of the data, hence confirming the Baumann observation.

In those cases where alternative methods of data collection have been described, it is questionable as to whether they would be of use in a comparative study of a high resolution or high sensitivity product category where the subtle difference in composition or source could significantly influence the relative position of an item. This is covered in Chapter 2.6, reflecting the wide array of materials, additives processes and sources of FSD.

Baumann cites "disassemble the product in order to weigh the constituent materials and components"; this is also cited by others within the study. This approach implies that each constituent material is a separable component, such as a rubber tyre and a metal wheel. This disassembly approach would not help in the quantification of components within a product that could be described from a purely visual perspective as mono-material but upon instrumentation based analysis turned out to be a composite material which included a range of components.

In a further comment regarding disassembly, one expert wrote in the questionnaire that "We could not identify the addition of any additives etc. We would take the view that these are likely in such low concentrations that they would not materially affect the result of the LCA and would be within the allowable omissions laid out in ISO standard as they would be below the acceptable weight \% threshold for omissions". While this may be true, it may need to be proven as it may influence the relative position of a product within a high resolution comparative product category.

Another approach described is the use of similar product LCA studies, technical literature, patents, product sales literature and information available from the internet. Questions can be asked as to how accurate this information would be as relates to identifying product inventory data for a product that could be initially described as mono-material but was then confirmed to be a composite which included a range of components.

When comparing a high resolution category of FSD items all appearing to be made of the same material type from a purely visual perspective, it may be that the above mentioned replacement approaches to stakeholder sourced product economic inventory data is not viable, especially given that FSD products may be made from composite materials not visible in a purely visual based study. 


\section{Review of Conclusions from Part 1}

FSD of like functionality tend to be a product category of high resolution, with fit-forpurpose product designs, often with very similar minimum product weights. To the naked eye, a visual based study, they could appear to be made from a single material. FSD are a product group that is growing and is a major user of resources; they are also often subjected to criticism for their perceived environmental negativity given their single use function.

To make a comparative environmental claim regarding a like functionality FSD category, LCA is considered. LCA is used in other claims such as the EU PEF. LCA and environmental claims were researched. Correct product economic inventory data was seen as imperative to an LCA study and of importance in an LCA study used to make a comparative assertion. It was cited that this data is predominantly sourced from product stakeholders but that stakeholder cooperation is unlikely with regard to FSD products.

This poses the question as to how product economic inventory data can be sourced in the absence of data from these stakeholders. Research into these sources was made resulting in numerous approaches. Questions could be asked as to the validity of these approaches with regard to the study of FSD products to be used in a comparative ECS.

Part 1 identifies factors that need to be addressed regarding any potential method. In a comparative study of like functionality items, to make an LCA based claim for FSD, it can be concluded that:

1. Product economic inventory data is required to perform an LCA.

2. Product inventory data being required for confirmation are like functionality, material composition and country of origin.

3. FSD are often light weight, fit for purpose designs that are seen as being made of a single material when viewed from a visual perspective.

4. Product inventory data is most commonly sourced from stakeholders.

5. FSD stakeholders are cited as being unlikely to be accessible or cooperative.

6. Alternative non-stakeholder approaches exist regarding product economic inventory data compilation.

7. Alternative non-stakeholder approaches that are most proposed by experts are: disassembly of the product, technical literature, visit retailers of similar products, use datasets of previous LCAs and ask producers of similar products.

8. It should be researched if these alternative non-stakeholder approaches to product economic inventory data compilation are adequate for identifying material composition in a high resolution FSD category. 


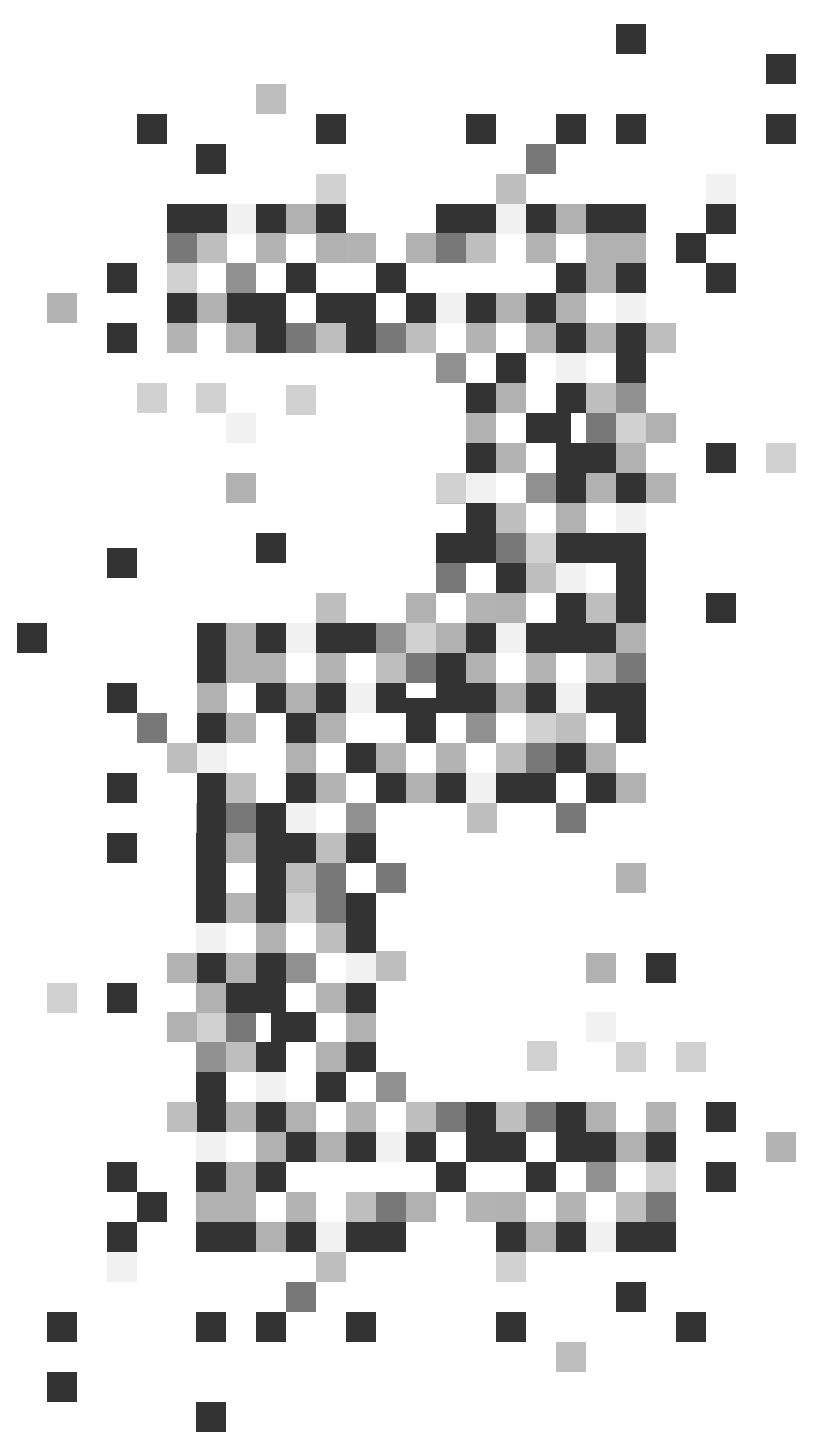




\section{PART 2}

In Part 1 of the study, "Describing the product, LCA, Comparative ECS and Product Economic Inventory", research question 1a "What are the factors that need to be addressed in developing a method?" was addressed. Factors were identified that require to be researched in accordance with the central research question:

CRQ: Is it possible to develop a method to optimize the quality of product economic inventory LCA input data, in support of product LCA based comparative claims, in the presence and absence of stakeholder cooperation?

In Part 2, research questions 2a to 2e will be addressed, in a context relevant for applications to FSD products:

RQ 2a. How should a functional specification be addressed for a comparative study of a particular category of FSD products?

RQ 2b. How should the material composition and processing details be determined for each product included in a comparative study?

RQ 2c. How should issues related to the country of origin identification of products or materials be taken into account, noting that in some cases such details might be uncertain?

RQ 2d. Do any further considerations need to be included in developing the method?

RQ 2e. What form could such a potential method take?

Part 2 of the study is addressed in Chapters 6 to 10 inclusive. 


\section{Chapter 6}

Applying the ReCiPe Approach, and
Defining a Suitable Scoring System 


\subsection{Introduction}

Chapter 6 will address the intended audience of the comparative product LCA based ECS as well as the associated goal and scope of such an ECS study.

It will further define the methods used to research the thesis, specifically those scoring systems to identify movements in relative position of an FSD product within a comparative ECS of a category of like functionality FSD items. Proving movement in relative position due to changes in product economic inventory data collection is an important outcome of the research. It gives insight into the importance of product economic inventory data collection approaches and an understanding of their relevance to LCA.

\subsubsection{The Intended Audience, Goal and Scope of the Comparative ECS}

In Chapter 5.2.2, reference is made to a questionnaire sent to LCA experts. This was followed up with face-to-face discussions. One consistent point from these discussions was: who is the intended audience for the studied comparative ECS?

It is assumed that the intended audience or user of such a study would be a party set on choosing a specific FSD product, from a range of like functionality FSD products, based on its relative environmental merits. Such a party might be intent on purchasing a fork from a series of available forks but wants to know the relative environmental impact of each of the available forks.

The goal definition determines the intended use of the study and, by association, the type of analysis required to achieve the goal. This decision required within this study is derived from the determination and demonstration of environmental preferability of a product.

Due to the resolution or sensitivity of the product ranges, the fact that the products can all be very similar to one another in impact requires that this be considered in the scope of the study. Some parties may consider that these small variances in impact between products may invalidate the requirement for a study; this is highly dependent on the quantity of the product to be consumed, which in the case of FSD can be very high.

In high resolution categories, the scope should cover the maximum amount of life cycle inventory as can be collected from the product raw materials, production processes and end-of-life scenarios (van der Harst-Wintraecken, E. J., 2015). The scope of the comparative product studies within this text will cover these three life cycle stages. The scope should also cover as much product economic inventory collection as is possible given the lack of stakeholder cooperation. 


\subsubsection{Scoring Systems to Identify Movements in Relative Position of a Product within a Comparative ECS}

It was decided that for each individual issue under study in RQ 2a to $2 \mathrm{~d}$ inclusive, four results will be displayed for each product within its product category, as follows:

1. A Numerical Value derived from an LCA based study of the product in order to show exact positioning within a category in a comparative ECS.

2. A Ratio to the Mean that shows the numerical value relative to the mean average represented as 1 .

3. A Rank Order of the products within the category based on the numeric value derived from an LCA based study, with the Rank Order being based on the lowest LCA based numeric value first.

4. A Star Rating that is a potential example of how the approach of the EU Directive 92/75/EC energy consumption-labelling could communicate relative environmental charge in a comparative ECS.

The above list of four results approaches is not exhaustive, other approaches could have been taken. It is not the objective of this study to research methods for communicating the relative position of a product within a comparative study.

Throughout the study the term "Demo", as relates to Demonstration product, will often be used to refer to the product in a category that undergoes a change in its economic inventory data for LCA input.

Important to this study is that a clear difference be made between a study of product inventory based on the current collection and identification methods described in Chapter 5 and a collection and identification method of enhanced accuracy as yet to be identified, the former being referred to as a "Current" or purely visual approach and the later as a "Detailed" approach.

\subsection{Numerical Value Indicator}

A single numeric value representing the environmental impact of a product would be most suitable for identifying rating. Changes in rating could be caused by potential changes in product economic inventory data derived from any differences in the Current and Detailed inventory collection approaches.

The numeric value representing the environmental impact of the product will be derived from an LCA using the ReCiPe methodology (Goedkoop, M., et al., 2009) endpoint total figure. The ReCiPe methodology is seen as contemporary, widely used and well recognized (Kalbar, P. P., et al., 2017). According to Bengtsson M., et al., 2000, what constitutes a good weighting method is transparency, simplicity in application and ease of communication of results, which could describe the ReCiPe methodology. 
Other methodologies could be used and the choice of ReCiPe in this case does not imply a methodology based preference.

As discussed in Chapter 3, the choice of impact weighting method may influence the relative position of an item within a category. The object of this study is to identify a potential benefit in the use of an objective product economic inventory assessment approach regardless of the weighting method chosen and therefore the choice for $\mathrm{ReCiPe}$ is not a major focus of this study.

In Subchapter 6.6, examples of the rating approach will be given, this will consider methodologies other than ReCiPe; however, the body of the research will exclusively use ReCiPe for the numerical value indicator.

Generic or secondary data will be used for the materials, processing energies, transports and incineration. Incineration will be adopted as the end-of-life scenario within the LCA studies of the FSD products; use-phase will not be considered, neither will any packaging related to the FSD product.

\subsubsection{ReCiPe}

Due to the use of ReCiPe (Goedkoop, M., et al., 2009) as the numerical value indicator throughout the study, it is important to provide further background into this methodology.

The numeric value in this study is derived from ReCiPe method, $(\mathrm{H})$ hierarchist perspective, total endpoint, using Ecoinvent v3.4 secondary LCIA data, within the LCA tool OpenLCA v1.6.3. As can be seen in Table 6.2 below, the numeric value to be used is the "Total - Total" single score.

ReCiPe is a method for the impact assessment in LCA. Using characterization factors, LCIA translates emissions and resource extractions into a limited number of environmental impact scores. The primary objective of the ReCiPe method is to transform lists of Life Cycle Inventory results into a limited number of indicator scores. These indicator scores express the relative severity on an environmental impact category.

The ReCiPe method combines both midpoint and endpoint modeling with 18 midpoint categories, notably climate change, ozone depletion, terrestrial acidification, freshwater eutrophication, marine eutrophication, human toxicity, photochemical oxidant formation, particulate matter formation, terrestrial ecotoxicity, freshwater ecotoxicity, marine ecotoxicity, ionizing radiation, agricultural land occupation, urban land occupation, natural land transformation, water depletion, mineral resource depletion and fossil fuel depletion. At the endpoint level there are 3 categories, notably damage to human health, damage to ecosystem diversity and damage to resources availability. 
ReCiPe uses a series of effects that together can create a certain level of damage, for example to human health or ecosystems, as the basis for its modelling. An example of this is climate change for which it is known that a number of substances increase the radiative forcing, preventing heat from being radiated out into space from Earth. As a result, more energy is trapped and temperature increases, leading to changes in habitats for living organisms, and the possibility that species may become extinct.

The overall structure of the ReCiPe method can be seen below in Figure 6.1, showing the impact categories and pathways covered by the methodology, from life cycle inventory to a final single endpoint score. The diagram shows five columns: the result of the Life Cycle Inventory, the environmental mechanisms they contribute to, the midpoints, the translation to environmental damage and the endpoint scores.

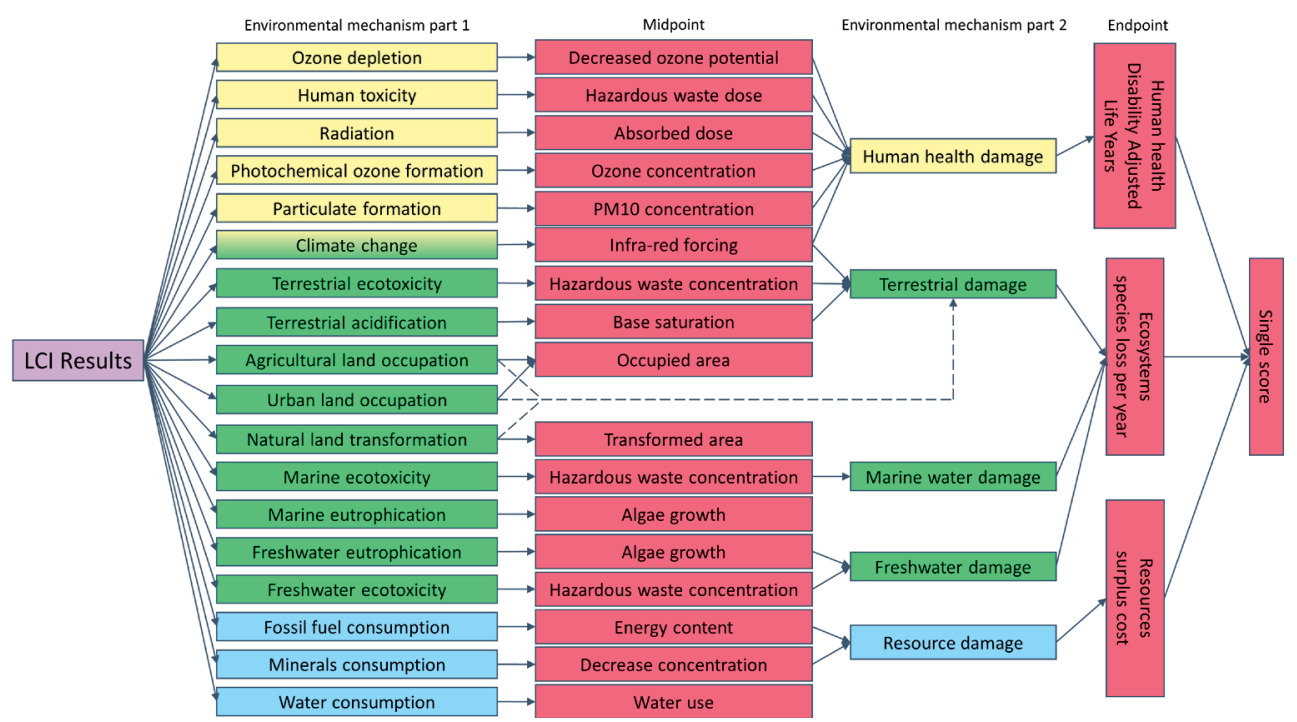

Figure 6.1: Relationship between LCI Parameters (left), Midpoint Indicator (middle) and Endpoint Indicator (right) in ReCiPe

The ReCiPe method groups different sources of uncertainty and different choices into a limited number of perspectives or scenarios. In this study, the hierarchist $(H)$ perspective model will be adopted which is based on the most common policy principles with regards to time frame and other issues. In the hierarchist perspective, the 100 year time frame is the most frequently used. The hierarchist model is often considered to be the default model. 
ReCiPe determines indicators at two levels:

Table 6.1: First level - Eighteen Midpoint Indicators

$\operatorname{ReCiPe}(\mathrm{H})$ Midpoint

\begin{tabular}{l|l}
\hline \multicolumn{1}{c}{ Impact Category } & \multicolumn{1}{c}{ Reference Unit } \\
\hline Ozone depletion & $\mathrm{kg} \mathrm{CFC-11-Eq}$ \\
\hline Human toxicity & $\mathrm{kg} \mathrm{U} 235-\mathrm{Eq}$ \\
\hline Ionizing radiation & $\mathrm{kg} \mathrm{NMVOC}$ \\
\hline Photochemical oxidant formation & $\mathrm{kg} \mathrm{PM10-Eq}$ \\
\hline Particulate matter formation & $\mathrm{kg} \mathrm{CO}-\mathrm{Eq}$ \\
\hline Climate change & $\mathrm{kg} 1,4-\mathrm{DCB}-\mathrm{Eq}$ \\
\hline Terrestrial ecotoxicity & $\mathrm{kg} \mathrm{SO}-\mathrm{Eq}$ \\
\hline Terrestrial acidification & $\mathrm{m}^{2} \mathrm{a}$ \\
\hline Agricultural land occupation & $\mathrm{m}^{2} \mathrm{a}$ \\
\hline Urban land occupation & $\mathrm{m}^{2}$ \\
\hline Natural land transformation & $\mathrm{kg} \mathrm{1,4-DCB-Eq}$ \\
\hline Marine ecotoxicity & $\mathrm{kg} \mathrm{N}-\mathrm{Eq}$ \\
\hline Marine eutrophication & $\mathrm{kg} \mathrm{P-Eq}$ \\
\hline Freshwater eutrophication & $\mathrm{kg} 1,4-\mathrm{DCB}-\mathrm{Eq}$ \\
\hline Freshwater ecotoxicity & $\mathrm{kg} \mathrm{oil-Eq}$ \\
\hline Fossil depletion & $\mathrm{kg} \mathrm{Fe-Eq}$ \\
\hline Metal depletion & $\mathrm{m}^{3}$ \\
\hline Water depletion & \\
\hline
\end{tabular}

Midpoint indicators are considered to be links in the cause-effect chain of an impact category at which characterization factors or indicators can be derived to reflect the relative importance of emissions or extractions (Bare, J. C., et al., 2000). 
Table 6.2: Second Level - Three Endpoint Total Indicators

\begin{tabular}{|c|c|}
\hline Human Health & Ozone Depletion \\
\hline Human Health & Human Toxicity \\
\hline Human Health & Ionizing Radiation \\
\hline Human Health & Photochemical Oxidant Formation \\
\hline Human Health & Particulate Matter Formation \\
\hline Human Health & Climate Change \\
\hline \multicolumn{2}{|c|}{ Human Health - total } \\
\hline Ecosystem Quality & Terrestrial Ecotoxicity \\
\hline Ecosystem Quality & Terrestrial Acidification \\
\hline Ecosystem Quality & Marine Ecotoxicity \\
\hline Ecosystem Quality & Freshwater Eutrophication \\
\hline Ecosystem Quality & Freshwater Ecotoxicity \\
\hline \multicolumn{2}{|c|}{ Ecosystem Quality - total } \\
\hline Resources & Fossil Depletion \\
\hline Resources & Metal Depletion \\
\hline \multicolumn{2}{|l|}{ Resources - total } \\
\hline Total - Total & Total of the Endpoint Totals \\
\hline
\end{tabular}

Endpoint characterization indicators are calculated to reflect differences between stressors at an endpoint in a cause-effect, such as measures of biodiversity change (Bare, J. C., et al., 2000).

An explanation of the individual LCIA categories and their associated equivalent units will be given in Appendix E.

\subsection{Use of the Ratio to the Mean as a Ranking Indicator}

The Ratio to the Mean indicator displays the position of a product's Numerical Value relative to the mean average (represented as 1) of the Numerical Value of all products in the same category. This figure is also used to calculate the Star Rating as described in Subchapter 6.5 below. 


\subsection{Rank Order Indicator}

In order to further demonstrate the effect of changes in product inventory data each product will be given a Rank Order number starting at 1 for the lowest Numerical Value product and rising per Numerical Value increase.

In the case where two products are 3rd equal in rank order, the three products behind them are ranked 5th, 6th and 7th, in order to keep the same total number of products in the category. This is likely to occur when it is identified that the same specific product is purchased by various vendors from the same manufacturer, this being a likely situation for FSD.

\subsection{Star Rating Indicator}

The Star Rating Indicator is adopted as a potential example of how the approach of the EU Directive 92/75/EC energy consumption-labelling, see Figure 6.2, could communicate relative environmental charge in a comparative ECS. In Chapter 2.10, the use of a Star Rating system was introduced. Star Rating provides clearly understandable context to a claim giving insight into the relative environmental load of a product. Three papers were cited in which it was stated that a Star Rating system would be a helpful approach to communicating the relative environmental load of a product to the consumer.

The use of a Star Rating system within this research is used to indicate the relative position of a product, taking account of any banded scale that may be used to communicate relative environmental charge in a comparative ECS. Research is required:

1. To show if small changes in a numeric value could have a significant effect on the position of a product within banded scales such as those used for a Star rating. This could highlight the importance of accuracy in identifying product economic inventory data.

2. To identify to what extent accuracy in product economic inventory identification is required in the case of high resolution categories in which very small changes in inventory data could have significant effect.

3. To identify to what extent accuracy in product economic inventory identification is required in the case of low resolution categories or spreads with bunching.

\subsubsection{Star Rating Indicator Method}

The numeric value of each product, as defined in Subchapter 6.2, are totalled then divided by the number of products within the like functionality category to give a mean of the numeric values of the chosen products.

The numeric value figure of each product is then compared for its relative position with regard to the mean by creating bands. The first band is the 2.5 Star band which sits, for example, between $-5 \%$ and $+5 \%$ around the mean. Each subsequent band, of increasing 
and decreasing impact, is set at a width of 10\% running out from the middle 2.5 Star band. Each subsequent band receives half a star less with $10 \%$ increasing impact and half a star more with 10\% decreasing impact as can be seen in Figure 6.3. There are hence 11 Star rating scores from 0 to 5 stars in increments of half a star.

The 10\% figure used for the band widths is purely indicative. In a high resolution category, it may be better to change this band width figure to better represent the spread of numeric values within the category: a large spread using a larger band width and a small spread using a smaller band width. This can be calculated by assessing the distance from the mean of the highest and lowest numeric values in the category. This approach may better represent very efficient or inefficient products within the category but is limited by a maximum band width of $20 \%$, with any bandwidth above $20 \%$, across this five Star Rating approach, leading to negative numbers for the higher Star ratings. Significant high scoring outliers will hence all be 5 Stars due to the limited number of bandwidths. This issue is evident in the energy-consumption label in which $\mathrm{A}+++$ type ratings are often reported.

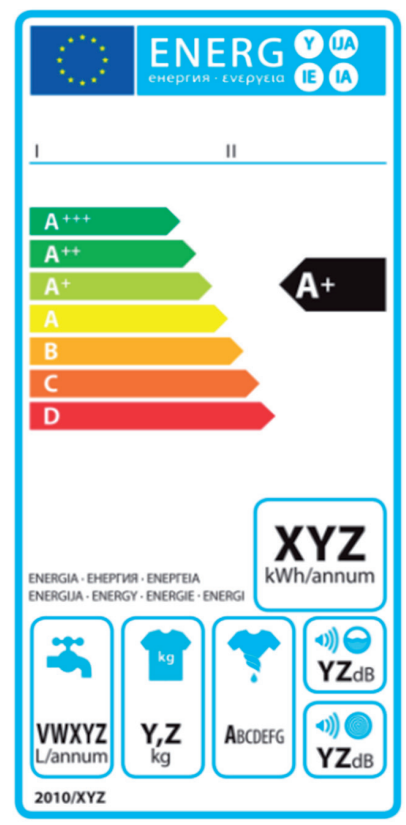

Figure 6.2: Energy Label with an A+++ Band 
Increased impact bands that are above the mean value run from 2.5 Stars down to 0 Stars; the decreased impact bands that are below the mean value run from 2.5 Stars up to 5 Star. This can be seen in the Figure 6.3 below:

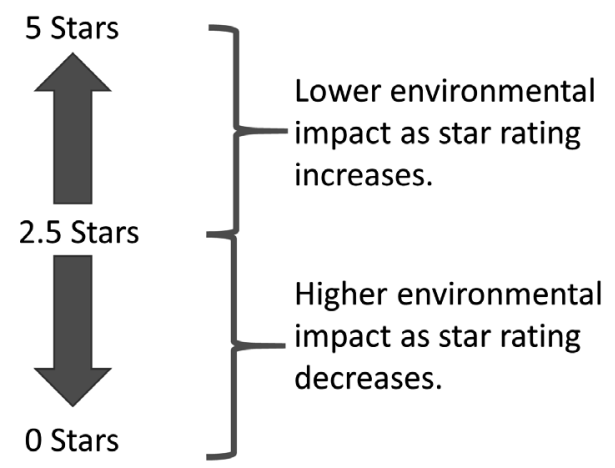

Figure 6.3: The Relative Value of the Star Rating in Environmental Impact terms

Each product is assessed as to the band in which its impact figure fits. This becomes the Star Rating of the product. Hence in the example below, a product with a Numerical Value of $45 \%$ or less than the mean average gets 5 Stars whereas a product with a numerical value of $45 \%$ or more than the average gets rated zero Stars.

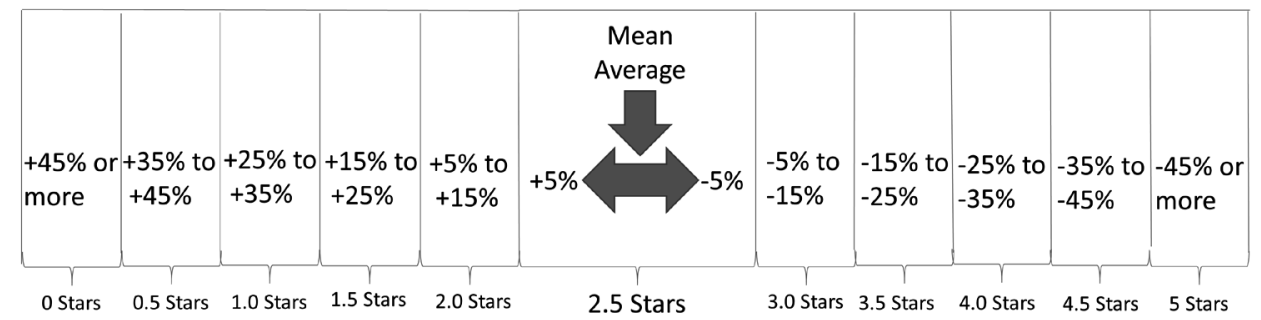

Figure 6.4: Star Rating Band Distribution

The Ratio to the Mean indicator aids in identifying the optimum bandwidth to adopt and aids in more efficiently identifying in which band a product should be placed. 
Table 6.3: Example of the 20\% Bandwidth Spread per Star Rating

\begin{tabular}{c|c|c}
\hline \multicolumn{3}{c}{ 20\% Bandwidth } \\
\hline Star & lower & upper \\
\hline $\mathbf{0}$ & 1.90 & \\
\hline $\mathbf{0 . 5}$ & 1.70 & 1.90 \\
\hline $\mathbf{1}$ & 1.50 & 1.70 \\
\hline $\mathbf{1 . 5}$ & 1.30 & 1.50 \\
\hline $\mathbf{2}$ & 1.10 & 1.30 \\
\hline $\mathbf{2 . 5}$ & 0.90 & 1.10 \\
\hline $\mathbf{3}$ & 0.70 & 0.90 \\
\hline $\mathbf{3 . 5}$ & 0.50 & 0.70 \\
\hline $\mathbf{4}$ & 0.30 & 0.50 \\
\hline $\mathbf{4 . 5}$ & 0.10 & 0.30 \\
\hline $\mathbf{5}$ & & 0.10 \\
\hline
\end{tabular}

For the purpose of this study, where a measured ratio value lies exactly on a range boundary the product is allocated to the higher Star score. For example, in Table 6.3 above, should a product achieve a Ratio to the Mean figure of 1.30, it will be accounted for as a 2 Star rated product.

The choice of such a linear Star Rating system as opposed to a system based on standard deviation relates to the fact that the quantity of products in a category could be small. A linear system can be used for both a very small and a very large quantity of products in a category.

It could be questioned if there should be some protocol for handling Star Rating studies dominated by one or two extreme outliers. If it is because such a product is so much worse than almost all of its competitors, should it be excluded from the combined study and receive an automatic zero Star rating, in comparison with the performance of so many of the alternatives? If it is because the outlier is so much better than others on the market, it should clearly be left in the study, rated well above all of its mediocre competitors.

\subsection{The Effect of Impact Assessment Methodology Choices}

To research the sensitivity of the assessment of a category of products, firstly as to how carefully the data on each is expressed and secondly to the "endpoint" weighting procedure adopted, a series of 8 disposable drinking cups were taken from the market and identified as category compliant, with these simple cups being the type typically used for cold beverage consumption such as water.

This relatively small number of products is used as an example in order to simplify the process of reviewing the data. There are eight products in the study, of which one is 
chosen to investigate the effect of recording its composition differently. The versions of this product are labelled as "DemoV1" and "DemoV2".

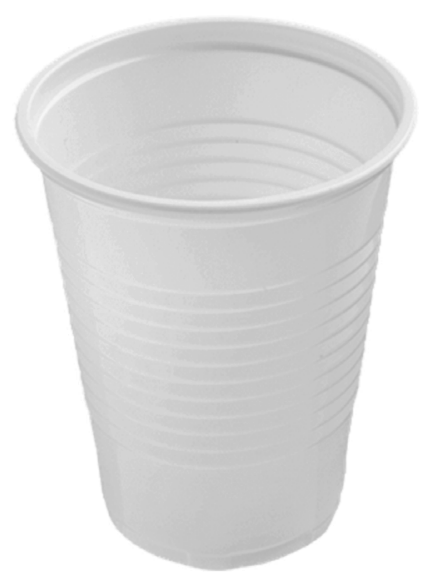

Figure 6.5: A Simple Drinking Cup

The cups vary in weight from $2.35 \mathrm{~g}$ to $2.7 \mathrm{~g}$ as can be seen in Table 6.4 below. They are sourced from Turkey, Spain, Italy, France and Croatia and are made using polypropylene (PP), Titanium Dioxide $\left(\mathrm{TiO}_{2}\right)$ and Calcium Carbonate $\left(\mathrm{CaCO}_{3}\right)$. The cup with the lowest ReCiPe endpoints total value is DemoV2 which weighs $2.5 \mathrm{~g}$ and is sourced in Italy. The cup with the highest value is DC4 which weighs $2.4 \mathrm{~g}$ and is sourced from Turkey.

Table 6.4: Drinking Cups in the Rating Example

\begin{tabular}{|c|c|c|c|c|c|c|c|c|c|}
\hline \multicolumn{10}{|c|}{ Drinking Cups } \\
\hline Cup No. & Unit & DC1 & DC2 & DC3 & DC4 & DC5 & DC6 & DemoV1 & DemoV2 \\
\hline $\mathrm{CoO}$ & & Turkey & Spain & Italy & Turkey & Croatia & France & Italy & Italy \\
\hline Total Weight & g & 2.350 & 2.500 & 2.600 & 2.400 & 2.700 & 2.700 & 2.500 & 2.500 \\
\hline PP Weight & g & 2.303 & 2.450 & 2.548 & 2.352 & 2.457 & 2.646 & 2.475 & 1.975 \\
\hline $\mathrm{TiO}_{2}$ Weight & g & 0.047 & 0.050 & 0.052 & 0.048 & 0.054 & 0.054 & 0.025 & 0.025 \\
\hline $\mathrm{CaCO}_{3}$ Weight & g & 0 & 0 & 0 & 0 & 0.189 & 0 & 0 & 0.500 \\
\hline
\end{tabular}

In addition to the 6 cups that make up the category, the two demonstration cups were assumed as follows:

DemoV1 - a PP drinking cup with no $\mathrm{CaCO}_{3}$ content and a total weight of $2.5 \mathrm{~g}$.

DemoV2 - the same PP drinking cup as DemoV1 but with $20 \%$ by weight of $\mathrm{CaCO}_{3}$.

The two Demo alternatives differ only in the explicit recognition of calcium carbonate filler. It has been common to treat polypropylene products as being pure PP, whereas 
detailed analysis recognizes the presence of a significant proportion of $\mathrm{CaCO}_{3}$. This filler is included in DemoV2 but not in DemoV1. The effect of this difference on the 7 product study is reviewed using each of three different endpoint weighting approaches.

Both demonstration cups are of the same weight and are visually identical. The reasoning for the choice of adding a $\mathrm{CaCO}_{3}$ filler is that it may go undetected by a Current product economic inventory based identification approach. The Current based assumption is hence that demonstration cup V1, being visually the same cup, is made entirely from PP and hence the $\mathrm{CaCO}_{3}$ could be easily missed; some accounting of the whiteness of the cup has been assumed by adding $1 \% \mathrm{TiO}_{2}$.

A further reason for the choice of $\mathrm{CaCO}_{3}$ is that it differs significantly in $\mathrm{LCIA}$ values from PP (Ecoinvent v3.4). Hence, in an LCA study of both demonstration cups, the V2 cup made of a composite of $20 \% \mathrm{CaCO}_{3}$ in PP should exhibit a lower overall impact figure than the $\mathrm{V} 1$ cup that is only made of PP.

Table 6.5: Example of Difference in ReCiPe Endpoints Total of PP and $\mathrm{CaCO}_{3}$

\begin{tabular}{|c|c|c|}
\hline Material & ReCiPe 2008 (H) & Endpoints \\
\hline PP & polypropylene production, granulate & 0.30378000 \\
\hline $\mathrm{CaCO}_{3}$ & limestone production, crushed, washed & 0.00065857 \\
\hline
\end{tabular}

The Numerical Value, Ratio to the Mean, Rank Order and Star rating will be displayed per Numerical Value methodology. In this case, the following impact assessment methodologies, which could be used to indicate environmental impact of a product, will be shown:

- ReCiPe endpoints total - the methodology to be used throughout the research

- Impact 2002+ (Jolliet, O., et al., 2003) endpoint

- $\quad$ IPCC 2013 - GWP 100a

A number of available life cycle impact methodologies could have been chosen, life cycle impact methodologies being cited as having differences in the scientific validity of their characterization models (Hauschild, M. Z., et al., 2013). The objective here is simply to research the change in relative position using different methodologies and to establish if different methodologies return different results, making it important for stakeholders to consider the most appropriate methodology type when preparing a comparative ECS.

The ReCiPe methodology is introduced above in Subchapter 6.2.1. The Impact 2002+ methodology takes a similar form, with similar impacts as well as midpoints and endpoints, whereas the IPCC 2013 methodology is significantly different from the other two as it results in a carbon footprint value of the products, completely excluding all resource, health and ecosystem impacts. 


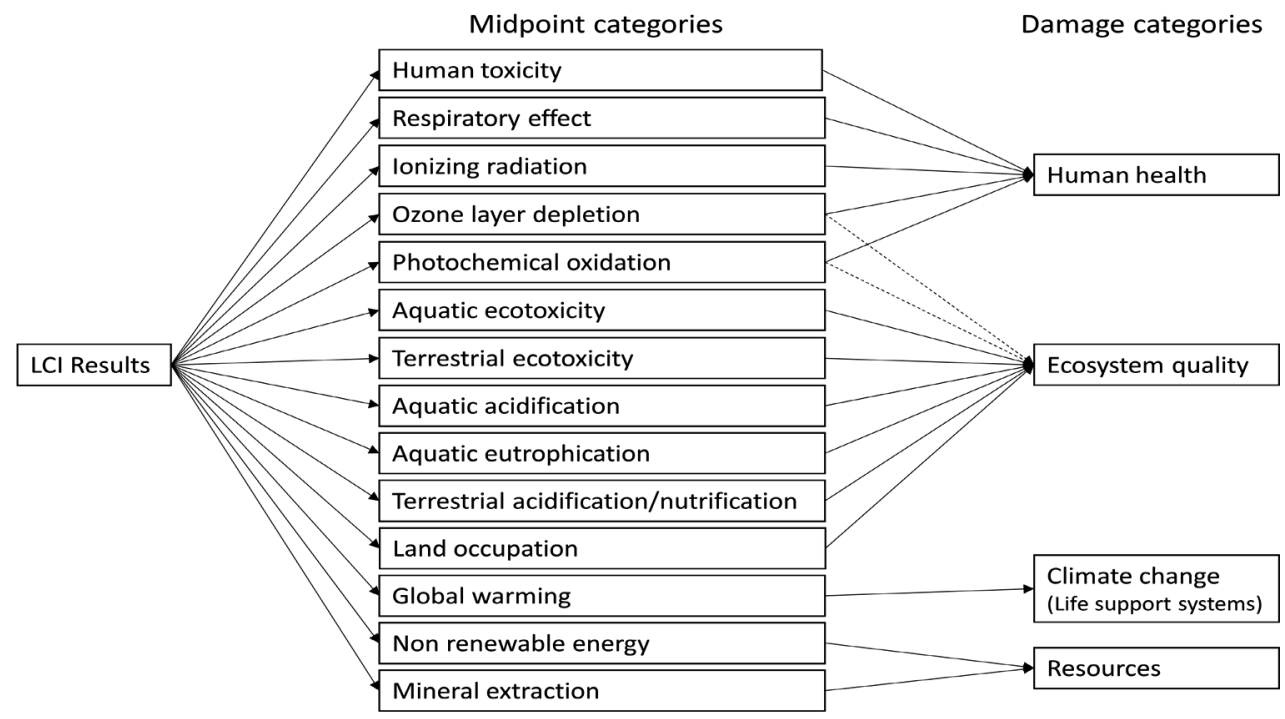

Figure 6.6: IMPACT 2002+ Framework, Linking LCI Results, via the Midpoint Categories, to Damage Categories

This Drinking Cup category Star Rating band widths are set at 5\% due to the relatively high resolution, or sensitivity, of this category. This reduced band width serves to further accentuate the difference between the cups.

The numeric outcomes in the six drinking cup studies below (Tables A to F) purely serve to research the difference in impact methodologies in support of the conclusion. The account of the detailed economic inventory analysis that arrives at these numeric outcomes will be covered in the following chapters within Part 2 of the study.

\subsubsection{ReCiPe}

Using the ReCiPe Endpoints total weighting method (Goedkoop, M., et al., 2009) and then applying the Ratio to the Mean, Rank Order rating and the Star Rating banding approach as described in Subchapter 6.5.1, the results show an improvement in score for the demonstration $\vee 2$ cup due to the identification of the $\mathrm{CaCO}_{3}$ fraction. 
Table 6.6: Table A - ReCiPe Weighted Method - Current Studied Demonstration V1 Cup (based on a single cup value)

\begin{tabular}{c|c|c|c|c}
\hline Drinking Cups & ReCiPe Endpoints & $\begin{array}{c}\text { Ratio to } \\
\text { the Mean }\end{array}$ & Rank Order & Star Rating \\
\hline DC1 & 0.00129 & 1.15 & 3 & 1 \\
\hline DC2 & 0.00106 & 0.95 & 5 & 2.5 \\
\hline DC3 & 0.00113 & 1.01 & 7 & 0.5 \\
\hline DC4 & 0.00132 & 1.18 & 2 & 3.5 \\
\hline DC5 & 0.00100 & 0.89 & 1 & 3.5 \\
\hline DC6 & 0.00099 & 0.88 & 3 & 3 \\
\hline DemoV1 & 0.00106 & 0.95 & & \\
\hline
\end{tabular}

Table 6.7: Table B - ReCiPe Weighted method- Detailed Studied Demonstration V2 Cup (based on a single cup value)

\begin{tabular}{c|c|c|c|c}
\hline Drinking Cups & ReCiPe Endpoints & $\begin{array}{c}\text { Ratio to } \\
\text { the Mean }\end{array}$ & Rank Order & Star Rating \\
\hline DC1 & 0.00129 & 1.15 & 4 & 1 \\
\hline DC2 & 0.00106 & 0.95 & 5 & 3 \\
\hline DC3 & 0.00113 & 1.01 & 7 & 0.5 \\
\hline DC4 & 0.00132 & 1.18 & 3 & 3.5 \\
\hline DC5 & 0.00100 & 0.89 & 2 & 3.5 \\
\hline DC6 & 0.00099 & 0.88 & 1 & 4.5 \\
\hline
\end{tabular}

It can be seen that due to the identification of the $20 \% \mathrm{CaCO}_{3}$ in the cup material, four products change their Rank Order number while the Star Ratings remain the same except for the case of the demonstration cups in which the identification of $\mathrm{CaCO}_{3}$ has led to an increase in the Star Rating.

The choice of a 5\% bandwidth for the Star Ratings has produced a good spread of Stars with only one Star rating being repeated twice, indicating low level of ReCiPe impact result bunching for this category of products.

\subsubsection{Impact 2002+}

Using the Impact 2002+ Endpoint weighting method (Jolliet, O., et al., 2003) and then applying the same Ratio to the Mean, Rank Order and Star Rating banding approach as described in Subchapter 6.5.1, the results show an improvement in score for the demonstration $\vee 2$ cup due to the identification of the $\mathrm{CaCO}_{3}$ fraction. 
Table 6.8: Table C - Impact 2002+ Weighted Method - Current Studied Demonstration V1 Cup (based on a single cup value)

\begin{tabular}{c|c|c|c|c}
\hline \multirow{2}{*}{ Drinking Cups } & \multicolumn{1}{c}{ Impact 2002+ Endpoints } & \multicolumn{2}{c}{ Ratio to the Mean } & \multicolumn{2}{c}{ Rank Order } & Star Rating \\
\hline DC1 & $4.745 \mathrm{E}-06$ & 1.32 & 6 & 0 \\
\hline DC2 & $3.122 \mathrm{E}-06$ & 0.87 & 3 & 4 \\
\hline DC3 & $3.141 \mathrm{E}-06$ & 0.87 & 4 & 4 \\
\hline DC4 & $4.846 \mathrm{E}-06$ & 1.35 & 7 & 0 \\
\hline DC5 & $3.461 \mathrm{E}-06$ & 0.96 & 5 & 3 \\
\hline DC6 & $2.955 \mathrm{E}-06$ & 0.82 & 2 & 4.5 \\
\hline DemoV1 & $2.894 \mathrm{E}-06$ & 0.80 & 1 & 4.5 \\
\hline
\end{tabular}

Table 6.9: Table D - Impact 2002+ Weighted Method - Detailed Studied Demonstration V2 Cup (based on a single cup value)

\begin{tabular}{c|c|c|c|c}
\hline Drinking Cups & Impact 2002+ Endpoints & Ratio to the Mean & Rank Order & Star Rating \\
\hline DC1 & $4.745 E-06$ & 1.34 & 6 & 0 \\
\hline DC2 & $3.122 \mathrm{E}-06$ & 0.88 & 3 & 3.5 \\
\hline DC3 & $3.141 \mathrm{E}-06$ & 0.89 & 4 & 3.5 \\
\hline DC4 & $4.846 \mathrm{E}-06$ & 1.37 & 7 & 0 \\
\hline DC5 & $3.461 \mathrm{E}-06$ & 0.98 & 5 & 2.5 \\
\hline DC6 & $2.955 \mathrm{E}-06$ & 0.84 & 2 & 4 \\
\hline DemoV2 & $2.501 \mathrm{E}-06$ & 0.71 & 1 & 5 \\
\hline
\end{tabular}

It can be seen that due to the identification of the $20 \% \mathrm{CaCO}_{3}$ in the cup material, there are no products whose Rank Order number changes while five products Star Ratings have changed.

The choice of a 5\% bandwidth for the Star Ratings has produced a poor spread of Stars with three Star Ratings being repeated twice in the case of Table 6.8, indicating a high level of Impact 2002+ result bunching for this category of products. The Impact 2002+ results have a larger spread than that of the ReCiPe results indicating that a larger bandwidth could better represent the spread. 


\subsubsection{IPCC 2013 - GWP 100a}

Using the IPCC2013 GWP 100a weighting method and then applying the same Ratio to the Mean, Rank Order and Star Rating banding approach as described in Subchapter 6.5.1, the results show an improvement in score for the demonstration V2 cup due to the identification of the $\mathrm{CaCO}_{3}$ fraction.

Table 6.10: Table E - IPCC2013 GWP Method - Current Studied Demonstration V1 Cup (based on a single cup value)

\begin{tabular}{c|c|c|c|c}
\hline \multirow{2}{*}{ Drinking Cups } & IPCC 2013 & Ratio to the Mean & Rank Order & Star Rating \\
\hline DC1 & 0.01036 & 1.14 & 6 & 1 \\
\hline DC2 & 0.00869 & 0.96 & 3 & 3 \\
\hline DC3 & 0.00934 & 1.03 & 5 & 2 \\
\hline DC4 & 0.01058 & 1.17 & 2 & 3 \\
\hline DC5 & 0.00800 & 0.88 & 1 & 4 \\
\hline DC6 & 0.00776 & 0.86 & 4 & 3 \\
\hline DemoV1 & 0.00874 & 0.96 & & 7 \\
\hline
\end{tabular}

Table 6.11: Table F - IPCC2013 GWP Method - Detailed Studied Demonstration V2 Cup (based on a single cup value)

\begin{tabular}{c|c|c|c|c}
\hline \multirow{2}{*}{ Drinking Cups } & IPCC 2013 & Ratio to the Mean & Rank Order & Star Rating \\
\hline DC1 & 0.01036 & 1.16 & 6 & 1 \\
\hline DC2 & 0.00869 & 0.98 & 4 & 2.5 \\
\hline DC3 & 0.00934 & 1.05 & 5 & 2 \\
\hline DC4 & 0.01058 & 1.19 & 7 & 0.5 \\
\hline DC5 & 0.00800 & 0.90 & 2 & 4.5 \\
\hline DC6 & 0.00776 & 0.87 & 1 & 4 \\
\hline DemoV2 & 0.00754 & 0.85 & & 4 \\
\hline
\end{tabular}

It can be seen that due to the identification of the $20 \% \mathrm{CaCO}_{3}$ in the cup material, there are 4 products whose Rank Order number changes and 3 products whose Star Rating changes. 


\subsubsection{An Overview of the above Impact Assessment Methodologies}

Table 6.12 below demonstrates the effect of adopting DemoV2 in a category in place of DemoV1 when studied using the same life cycle impact methodology, such as in the case of comparing Table A with Table B. It then further demonstrates that this affect differs for the different life cycle impact methodologies, such as comparing Tables A and B with C and $D$ and $E$ and $F$.

Table 6.12: An Overview of the above Tables based on Three Impact Assessment Methodologies

\begin{tabular}{|c|c|c|c|c|c|c|c|c|c|c|c|c|}
\hline \multirow[b]{3}{*}{$\begin{array}{l}\text { Drinking } \\
\text { Cups }\end{array}$} & \multicolumn{4}{|c|}{$\mathrm{ReCiPe}$} & \multicolumn{4}{|c|}{ Impact 2002+ } & \multicolumn{4}{|c|}{ IPCC 2013 GWP } \\
\hline & \multicolumn{2}{|c|}{$\begin{array}{c}\text { Table A } \\
\text { DemoV1 }\end{array}$} & \multicolumn{2}{|c|}{$\begin{array}{c}\text { Table B } \\
\text { DemoV2 }\end{array}$} & \multicolumn{2}{|c|}{$\begin{array}{c}\text { Table C } \\
\text { DemoV1 }\end{array}$} & \multicolumn{2}{|c|}{$\begin{array}{l}\text { Table D } \\
\text { DemoV2 } \\
\end{array}$} & \multicolumn{2}{|c|}{$\begin{array}{c}\text { Table E } \\
\text { DemoV1 }\end{array}$} & \multicolumn{2}{|c|}{$\begin{array}{c}\text { Table F } \\
\text { DemoV2 }\end{array}$} \\
\hline & $\begin{array}{l}\text { Rank } \\
\text { Order }\end{array}$ & $\begin{array}{l}\text { Star } \\
\text { Rating }\end{array}$ & $\begin{array}{l}\text { Rank } \\
\text { Order }\end{array}$ & $\begin{array}{l}\text { Star } \\
\text { Rating }\end{array}$ & $\begin{array}{l}\text { Rank } \\
\text { Order }\end{array}$ & $\begin{array}{l}\text { Star } \\
\text { Rating }\end{array}$ & $\begin{array}{l}\text { Rank } \\
\text { Order }\end{array}$ & $\begin{array}{l}\text { Star } \\
\text { Rating }\end{array}$ & $\begin{array}{l}\text { Rank } \\
\text { Order }\end{array}$ & $\begin{array}{l}\text { Star } \\
\text { Rating }\end{array}$ & $\begin{array}{l}\text { Rank } \\
\text { Order }\end{array}$ & $\begin{array}{c}\text { Star } \\
\text { Rating }\end{array}$ \\
\hline DC1 & 6 & 1 & 6 & 1 & 6 & 0 & 6 & 0 & 6 & 1 & 6 & 1 \\
\hline DC2 & 3 & 3 & 4 & 3 & 3 & 4 & 3 & 3.5 & 3 & 3 & 4 & 2.5 \\
\hline DC3 & 5 & 2.5 & 5 & 2.5 & 4 & 4 & 4 & 3.5 & 5 & 2 & 5 & 2 \\
\hline DC4 & 7 & 0.5 & 7 & 0.5 & 7 & 0 & 7 & 0 & 7 & 1 & 7 & 0.5 \\
\hline DC5 & 2 & 3.5 & 3 & 3.5 & 5 & 3 & 5 & 2.5 & 2 & 3.5 & 3 & 3.5 \\
\hline DC6 & 1 & 3.5 & 2 & 3.5 & 2 & 4.5 & 2 & 4 & 1 & 4 & 2 & 4 \\
\hline Demo & 3 & 3 & 1 & 4.5 & 1 & 4.5 & 1 & 5 & 4 & 3 & 1 & 4 \\
\hline
\end{tabular}

The above yellow cells indicate changes in rating values between a category with DemoV1 compared to the same category with DemoV2 for the same impact assessment methodology.

It can be seen that due to the identification of the $20 \% \mathrm{CaCO}_{3}$ in the cup material, DemoV1 and $V 2$ are awarded different ratings for all of the above chosen impact assessment methodologies, as can be seen in the tables in Subchapter 6.6.1, 6.6.2 and 6.6.3. The presence of $\mathrm{V} 1$ versus $\mathrm{V} 2$ in a study does not affect the relative rank orders of DC1 to DC6, but, because of the resulting change in the Mean value (across the set of 7 cups), the Star Rating values change a little, to the extent that some adjacent products may share the same Star Rating in one analysis but be separated by a grade boundary in the other.

Whilst these three different weighting models differ to some extent in their detailed outcomes, these differences are relatively minor. This is generally reassuring.

It can be concluded that the choice of impact assessment methodology has an influence on the relative position of a product within the category.

From this point forward, all research will adopt the ReCiPe model. 


\subsection{The Effect of Setting Bands}

While impact assessment weighting methodology choices will influence the relative position of a product within a comparative study, the way the impacts on the item are expressed may also lead to differences in result. In this example, the choice of band widths in order to apply a Star Rating.

The inclusion of certain products within a category may function to create bunching within the banded scale of the comparative ECS. This affects the Mean of the scale and, as such, some incremental environmental improvements may go unnoticed. The greater spread of impacts across the category, the greater the chance of bunching and hence the chance that impact improvements go unnoticed in the Star Rating. In the case of the Rank Order, an item will retain its ranking regardless of any bunching affect.

\subsection{The Effect of Different Inventory Collection Approaches of Multiple Products within a Category}

In the studies of multiple like functionality products above and below, there will be comparisons between two of the same product, of which one is based on Current inventory collection approaches, as described in Chapter 5, and the other whose inventory has then been collected by approaches researched in this study. This comparison of a single product is chosen to simplify the research; however, it could be that a study of multiple like functionality products may contain a range of products for which there are differences in economic inventory due to the different inventory collection approaches.

It is possible that the situation as regards the effect of one product could be similar for all products of differing inventory collection approaches.

\subsection{Chapter 6 Conclusions}

This study will use the following proposed methods:

1. Numerical Value Indicator - ReCiPe - as described in Subchapter 6.2

2. Ratio to the Mean - as described in Subchapter 6.3

3. Rank Order Indicator- as described in Subchapter 6.4

4. Star Rating Indicator- as described in Subchapter 6.5

in order to track, test and research the implications of systems of product economic inventory input identification for comparative claim purposes in the absence of stakeholder input. This does not imply the method is ideal or in any way superior to other weighting systems; it is simply a method to demonstrate the effect of changes in product economic inventory data within Part 2 of this study. 
Impact assessment weighting and the setting of bands will influence the relative position of an item within a comparative study. This must be considered when choosing a method and an approach when designing a comparative based claim.

Ratings derived from studies in which there are issues of bunching is of concern as this could work to discourage eco-innovation of FSD, while the objective of comparative claims could be seen to be the encouragement of competition in eco-innovation.

It is evident, from the above, that the use of a Current approach to further identify LCA inputs in the absence of stakeholders will have an influence on all chosen weighted impact assessment methods.

The following chapter will use the research methods described in this chapter to identify the effect of the relative position of a product within a comparative ECS as relates to choices of category compliance rules and functional unit choices. 


\section{PART 2}

Chapter 7

The Functional Unit 


\subsection{Introduction}

In Chapter 4 it was cited that the quality, function, technical performance and use of comparative products must be identical if they are to be included within the same product category for which a comparative claim is made. The products should also be representative of those of like functionality that are available as an option within the market of study.

After defining the goal of an LCA study, the next step consists of defining the functional unit (FU) to be considered, i.e. defining precisely the various functions to be accomplished by the different product systems. This allows an objective comparison of performances corresponding to the different routes used to realize the same functional unit. All product systems in a comparative LCA must comply with the functional unit (Van der Harst-Wintraecken, E. J., 2015).

The value of identifying functional compliance, especially of FSD products that are often of minimal fit-for-purpose design, can be important. A weak cup may encourage a user to double-cup in which one cup is placed inside another, leading to the use of two cups for the same function. If a fork is weak and it breaks, it is possible that a second fork is taken or that no fork function is available to the user if they are then far from the original source of the forks, as in the case of a takeout meal then eaten on a train.

This chapter will seek to analyse the challenges associated with defining product functionality rules (PFR) as regards product choice, and the FU of the study, in the absence of the product stakeholders, in accordance with research question 2 a within stage 2 of the study:

RQ 2a. How should a functional specification be addressed for a comparative study of a particular category of FSD products?

Research will be carried out to understand the approach to be taken that could maximize objectivity in establishing PFR and the eventual FU of the study in addition to the associated variables within the approach and what effect these variables will have on the relative position of a product within a comparative ECS.

The lack of product stakeholder input would require that the identified product function for compliance to the PFR be as objective as is possible in order to avoid possible bias in the product choices for inclusion in a comparative study. It is questionable if all the functions intended by the absent stakeholder of the product can ever be known.

The opportunity for passive ignorance (i.e. we do not know what we do not know) in the mechanical testing for PFR is limited, as is active ignorance (i.e. deliberately ignoring aspects due to limited knowledge or lack of care in understanding something). Reliability is high, due to "the level of confidence in the state-of-the-art knowledge that is facilitated by using well accepted methods or measuring equipment and/or by following well-accepted protocols in applying those methods or equipment" (Van der Harst-Wintraecken, E. J., 2015). 


\subsection{Function, Functional Specification, Product Functionality Rules and Functional Unit}

To what extent does the choice of function within the FU influence the relative position of a product in a comparative ECS? As was shown in Chapter 6, the choices of weighting methodology in LCA studies affects outcome; this may also be the case regarding the choice of function in the FU and thus should be researched.

Claims to third parties, such as those discussed in Part 1 of this study, must be understood in relation to function within the FU choices. It could be questioned whether the claim reader, possibly a consumer, would take the time to identify the function in the FU used in the study that produced the result displayed before them.

Complexity exists in the definition of the term function (Klooster, R. ten, 2002) in which levels of function exist. Product groups identified that comply with the function, described in the FU, may consist of products of multiple other functional specifications (FS), so-called subfunctions or supplementary functions (Delhoofen P.J.W.M., 1994). For the consumer to be told a product is performing poorly in a study in which its FS is not fully represented could be construed as negatively associating specific products. This does not mean that, in using a more general FU, an objective comparison cannot be made but, rather, it could be questioned if this comparison is representative of the full FS benefits of all products in the category.

This consideration of the FS of a product with regard to the function, defined in a FU, in an LCA study will be researched. A description of the various terms used with regard to functionality are defined in Figure 7.1 below:

Function - An activity that is natural to, or the purpose of, a person or product. Related to a product: what the product must do.

Product Functionality Rules (PFR) - The rules of function that a product must adhere to in order to qualify for the like functionality category.

Functional Unit (FU) - "A functional unit is a quantified description of the performance of the product systems, for use as a reference unit" (Weidema, B., et al., 2004).

Functional Specification (FS) - Specifies the functions that a system or component must perform (ISO/IEC/IEEE 24765-2010).

Reference flow - Amount of the product necessary for a specific product system to deliver the function (Weidema, B., et al., 2004).

Figure 7.1: Definitions of Function, PFR, FS, FU and Reference Flow 
Examples of the various functional requirements of a cup are listed in Figure 7.2 below as well as examples of the types of functional properties that could be required, and possibly measured, to achieve the required function.
a) holding hot or frozen content for a certain amount of time: insulation properties
b) being able to hold the cup: strength, stiffness, surface friction, contact temperature
c) being able to drink out of the cup: no sharp edges, no surprise regarding the contents' temperature
d) stacking in boxes with a certain load: is the box carrying the load or are the stacks?
e) protect the taste of the coffee: no odour uptake by the coffee from the cup
f) vendibility
g) print or embossing possibility, transparency, lid-able
h) made of a material aligned to a specific end-of-life scenario

Figure 7.2: Example PFR for a Cup 


\subsubsection{Consideration of Functional Unit in Scientific Research}

To research the above, it is necessary to identify current FU choices within scientific research on the subject of comparative environmental claims with regard, in this case, to FSD.

A list of FU descriptions, taken from scientific research papers, is listed in the table below. These papers cover a range of different FSD and different FU choices.

Table 7.1: The Function and Functional Unit in LCA Studies relating to FSD

\begin{tabular}{|c|c|c|c|c|}
\hline Source & Year & FSD & Functional Unit & Function \\
\hline CarbonClear & 2012 & cups & 1 & a cup \\
\hline Denison, R. & 1998 & cups & & \\
\hline Franklin Associates & 2011 & cups & 10000 & FSD products \\
\hline Garrido, N. et al & 2007 & cups & & \\
\hline Hakkinen et al. & 2010 & cups & & \\
\hline Hocking, M.B. & 1994 & cups & & \\
\hline Hunt, R. & 1998 & cups & & \\
\hline Merugula et al. & 2014 & cups & & \\
\hline Minter & 2014 & cups & & \\
\hline Potting, J. et al. & 2014 & cups & 1 & $\begin{array}{l}\text { facilitating the serving of one hot beverage } \\
\text { from a vending machine as frequently used } \\
\text { in the Netherlands in big organizations }\end{array}$ \\
\hline TNO & 2007 & cups & 1000 & $\begin{array}{l}\text { dispensing of hot drinks from } \\
\text { a vending machine or dispenser }\end{array}$ \\
\hline Vercalsteren, A. & 2010 & cups & 100 & recipients needed to serve beer or soft drink \\
\hline Woods, L., et al. & 2014 & cups & & \\
\hline Ziada, $\mathrm{H}$. & 2009 & cups & & \\
\hline Broca, M. & 2008 & plates & 2960 & plates \\
\hline Franklin Associates & 2011 & plates & 10000 & FSD products \\
\hline To, K., et al. & 2006 & plates & 1 & plate \\
\hline Wachter, et al. & 2013 & plates & 1 & bowl \\
\hline Brownlee, A., et al. & 2013 & cutlery & 1 & utensil \\
\hline Degli l., et al & 2007 & cutlery & 1000 & meal servings \\
\hline Jishi, S. & 2013 & cutlery & 1 & cutlery type \\
\hline Razza, F., et al. & 2009 & cutlery & 10000 & meal servings \\
\hline
\end{tabular}

In the above studies cited in Table 7.1, the FU simply represented a number of meals, an amount of beverage or a quantity of FSD products. The FSD products were all assumed to provide the 
service of facilitating the consumption of the specified quantity of meals or beverage amount. Little reference is made to the FS of the individual products within the study.

The following FSD categories were studied in the above Franklin Associates (2011b) LCA study:

- 16-ounce hot cups (EPS foam, polymer-coated paperboard with and without a corrugated sleeve, PLA-coated paperboard with and without a corrugated sleeve)

- 32-ounce cold cups (EPS foam, polymer-coated paperboard, wax-coated paperboard, PLA)

- $\quad$ 9-inch high grade plates (GPPS foam, polymer-coated paperboard, bleached moulded pulp, PLA)

- $\quad$ Sandwich-size clamshells (GPPS foam, corrugated paperboard, PLA)

While each of the above items do perform the function of FSD (the functional unit in the Franklin study), each item has a differing range of further FS.

Taking the clamshell item above, both the GPPS foam and the corrugated paperboard clamshells are obviously not transparent but could provide insulation in the case of a hot sandwich. The solid PLA clamshell is transparent but could not be said to be insulating and PLA has a Heat Deflection Temperature - ASTM D648 of $49^{\circ} \mathrm{C}$, potentially making it unsuitable for use with warm foods.

Similar observations could be made regarding the cups in which EPS cups are compared to polymer-coated paperboard cups without corrugated sleeves: EPS offers very significant insulation while the paperboard offers more limited insulation.

The generalistic nature of the function, as relates to the Franklin FU, allows for the additional FS of the above cups and clamshells to go unrecognized.

Is the reader of comparative ECS likely to identify and understand the function in the FU, especially if it is in the form of an energy-label or Star Rating type label? If they do not, it could be possible that they would simply continue to associate the poor scoring product as a negative option regardless of the function. If this is the case then the choice of the FU would appear to have to be chosen with responsibility and could be said to have to properly represent the FS of the FSD products chosen.

Determining a FU is not always straightforward as many products are multi-functional (Merugula, L., 2013).

The question is: in a comparative study, to what level of specification does a function need to be defined for the FU to correctly represent the product within the study while making sure its full FS is represented? It could be questioned whether a greater level of function definition is required compared to the function definitions identified in Table 7.1. 


\subsection{An Approach to Formulating PFR for FSD}

In developing a comparative ECS, it is vital to establish the product category into which the product being studied is to fit (Subramanian, V., et al., 2012).

The benefits derived from Product Functionality Rules could be seen to be:

1. consistency and comparability of assessments based on the same rules

2. modularity of assessment scope

3. transparency of requirements and in the development process

4. guidance and clarity to users undertaking assessments within the sector

5. flexibility of use by any entity

Product functionality varies greatly within the FSD sector; a fork has very different functionality requirements compared to a cup. Generalized rules are difficult to establish but are an important goal if all products of an embodied impact nature are to be subject to comparative based claims.

A product category choice approach, for a comparison of products from a specific market, could reasonably be seen to require consideration of the following:

\subsubsection{Product Type}

The choice of the type of product would be that of the claim/label maker.

Example: disposable plate

\subsubsection{Market}

The products would have been chosen from a specific market, for example retail, food service, airline, as these differing markets may offer different designs and functions for the chosen product.

Example: disposable plates from the retail sector

\subsubsection{Territory}

The territory from which the competing products are collected, for inclusion within the category, may have to be considered as differing national markets may offer products of differing design or functionality. This territory should not be confused with the country of origin of the products within the category.

Example: disposable plates from the retail sector in the Netherlands 


\subsubsection{Date}

The date on which the competing products are collected, for inclusion within the category, may have to be defined in order to show that the items were available in the market on that date. This could be seen as important as product offerings may change over time.

Example: disposable plates from the retail sector in the Netherlands collected on 24th and 25th March 2013

\subsubsection{Product Functionality}

The chosen product will have a specific functionality. It may be grease-proof, heat resistant and have a specific carrying strength across a plate width. These functionalities, together with their associated tests and test results, could be listed in order to defend why certain potentially competing products are excluded from the final product category.

Example: disposable plates from the retail sector in the Netherlands collected on 24th and 25th March 2013 conforming to the following like functionality specification......

\subsubsection{Product Primary Category}

Once a specific product has been chosen, all like-products from the specified market in the specified territory on the specified date could be included in a primary category. All of these items form the "primary-category", essentially being all similar products that have not yet been tested for their like functionality comparison with the chosen product.

The collection of items for the primary category should ideally represent a known and reasonable percentage of the market share. Questions as relates to the market representativeness of the products chosen would appear to depend on the claim made. This is not addressed within this study.

\subsubsection{Primary Category Product Testing}

The chosen product will have a specific functional specification (FS) (Lutters D., et al., 2008). The primary category products must also have this FS. Those primary category products that do not have the required FS could be listed with the reasons for their rejection. Those products that do meet the specific FS definition could be added to the final product category.

As proof of compliance to FS, relevant physical, tactile and mechanical tests could be made of the collected products for comparison with the test results of the chosen product.

\subsubsection{The Final Product Category}

The final category is made up of those products that pass the like functionality testing and hence could be added to the range of products covered in the comparative ECS. 
It should be noted that the specific category rules may change between product groups, especially as relates to functionality. It is evident that a fork and a soup bowl have different requirements placed upon them.

\subsection{Examples of Methods for Establishing the Like Functionality of FSD Being Compared}

It is necessary to compare items from the same primary category based on their functionality. Individual tests will be required to be adapted per product category sort based on the FS. Evidentially, the functionality comparison criteria derived from the FS for two cups are different than for two forks, based on the pressures and requirements put on them in their use. All these technical criteria could be quantitatively specified to provide a comparison of like functionality for a product category.

An initial product category target definition would need to be established, for example this could be one of the following:

- $\quad$ Light weight fork

- $180 \mathrm{ml}$ vending cup

- $\quad 22 \mathrm{~cm}$ diameter single compartment light weight plate

Once the claim maker has defined the category, PFR can be addressed.

This functionality will be based on the requirements expected from the product at the point of its use. A consumer expects a product to behave to their expectation or that of the description on the label, without injury. This functionality comparison is likely to have nothing to do with outer packaging or transport efficiencies or any efficiencies further back in the supply chain.

In the case of FSD, they should not have to consider the food contact approval of the FSD, as all items would have to be certified as food contact approved according to legislation and must be safe to use (no sharp edges). It should be noted that any contaminants such as heavy metals in plastics or organics like bisphenol-A in paper or board, or biocides in wood, may be cited at the point of materials identification. Items containing these contaminants above permissible levels would also have to be considered for rejection.

\subsubsection{Example Testing of FSD in relation to their Function}

The definition of the target functionality is, in part, subjective. Being based on the description of the product category and the consumer expectation from that category, this input would likely come from marketers. However, once the target functionality and the acceptable variance band are established, objective measurements could be made to establish if a product fulfils the target PFR. 
Examples of like functionality are given below as are some recommended testing. Further in depth study of like functionality of a specific FSD is given in Chapter 7.5 in order to test the eventual effect on the relative position of a product within a comparative ECS.

The FS is that a disposable fork should be able to carry a certain amount of food and that it can hold food while being cut. This will lead to technical requirements, such as forces and loads. A disposable fork or spoon can be measured for its length and weight plus the average maximum force or average displacement at maximum force in order to provide a comparison of strength, see the picture below:

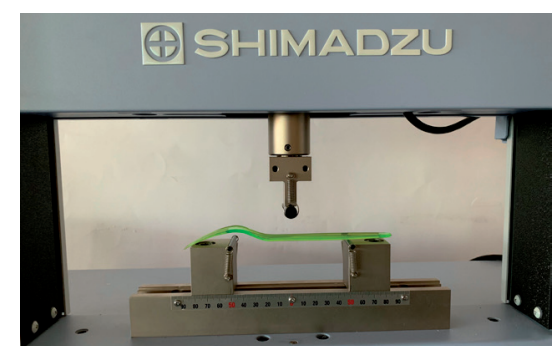

Figure 7.3: Fork Compression Testing

In the case of a knife, as part of the Cutlery category, the above measurement of strength should involve a similar downward force at a similar position to the fork but with the knife on its side to simulate spreading, and down through the blade to simulate cutting.

In the case of coffee cups, insulation for hot liquids may be a tactile functionality requirement in the category. In this case, the cups could be filled with boiled water and have their outer wall temperature measured.

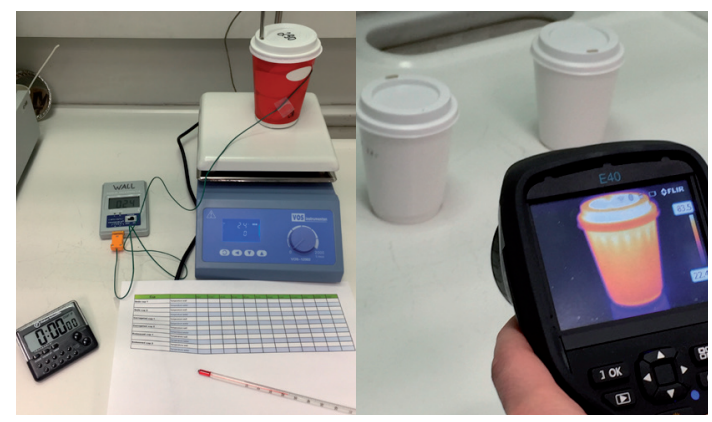

Figure 7.4: Cup Insulation Testing

Cup weight and fill capacity is important and measurable. Thereafter, the sidewall compression of the cups could be measured (Chinese Standard - QB/T 27590, 2011) to compare strength at a specific hot beverage temperature at a specific point on the cup. 


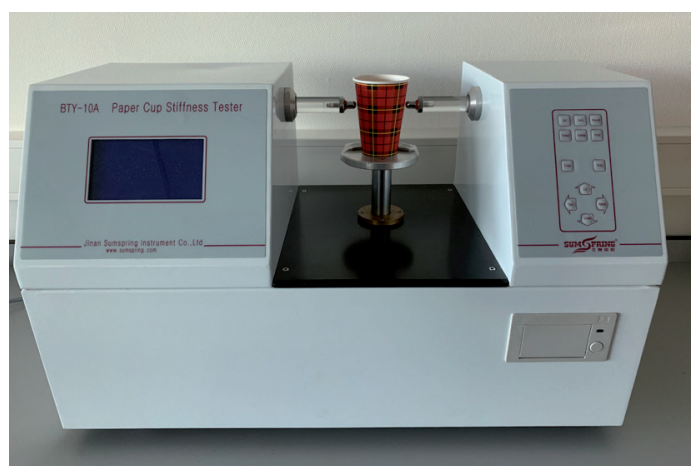

Figure 7.5: Cup Wall Stiffness Testing

A PFR could be established from the category description and functionality data derived from the tests above. In the case of a Heavy Duty fork, the fork is seen as a disposable version of the durable table fork. This could imply a length requirement. The weight would require to be high for a disposable, as is indicated in the category name. Many light weight forks of equal length are also available; these might not be included in the category, especially if a minimum figure is given for strength in the PFR.

Once the target functionality of length and weight has been defined for these forks, a variance from the target would need to be considered. All forks within the variance band could be accepted and their strength would then be tested. Based on an average of the strength, any forks with a strength below a predefined variance could be rejected. Had the weight not formed part of the description of the product, then an equal length, equal strength, lighter weight item could have been chosen.

Unfortunately, no single set of fixed rules can be applied for all FSD items from a PFR perspective. Coffee cups require consideration of insulation; strength tests for forks and spoons differ from knives due to different use requirements of a knife; plates may be used for cold or hot, dry or wet or greasy foods and their food contact surface has to reflect that use; coffee stirrers have to stir sugar or dried soup in the hot liquid without curling or going soft (see below Figure 7.6).

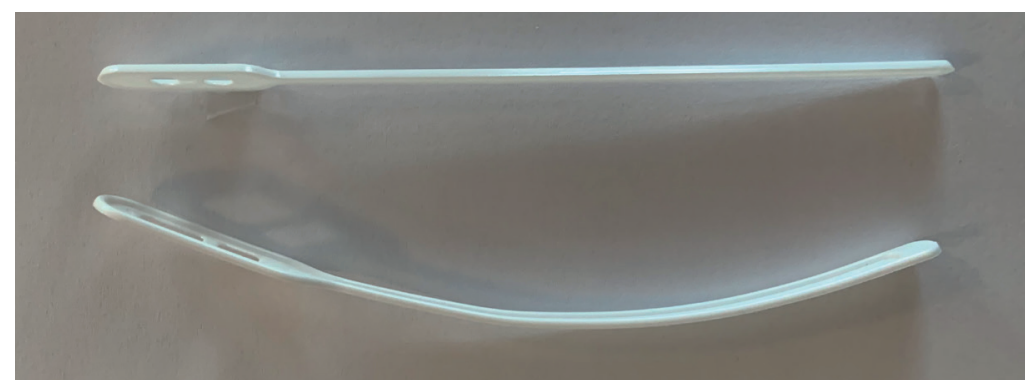

Figure 7.6: Stirrer Types after Boiling Water Testing 
As the number of FSD categories grows to include napkins, serviettes, carry-out bags, trays, and the numerous other FSD, it is again evident that a fixed overall PFR cannot be established.

Categories are made up of numerous material types. In the case of the $22 \mathrm{~cm}$ diameter plates below, various plastics, composites and paper boards with various coating types are included. Material types should not be used to define the category choices, unless the material type is specifically part of the PFR or the FS can only be achieved by using one specific type of material.

Arriving at conclusions of material performance when comparing items of like functionality can be misleading, such as in the assumption that one material type will always outperform another. In the lowa State University study into cutlery (Demmer, B.J., 2011), the conclusion was that the bio-based cutlery had similar mechanical properties to PS cutlery, the PS cutlery had fewer supporting ribs in its design than the bio-based cutlery, and the biobased cutlery was up to twice as heavy as the PS equivalent. In this case, it takes twice as much material to meet the like functionality specification, indicating that each item must be individually studied. While certain materials may be less environmentally impactful by weight, their poorer yield in terms of finished product may render their product the more environmentally impactful choice in a comparative study of like functionality products. This same inefficiency could also relate to their conversion processes.

\subsubsection{22cm Diameter Plates Testing Method}

In the case of the $22 \mathrm{~cm}$ diameter plates, it could be important to establish the FS and the associated PFR, examples of which are listed below:

1. a specific size of plate in terms of diameter or surface area

2. to hold food, hence required to have a surface that is food contact approved

3. to hold food of a specific weight

4. to be held with one hand

5. to hold food of a specific weight with a loading on the plate area opposite the holding hand

6. to not exceed an established and maximum displacement (see Figure 7.7 below)

7. to hold food of a specific temperature

8. to hold food of a specific water and fat content

9. to hold food for a specific time

All of the above PFR can be tested objectively to qualify a product for inclusion in the category of like functionality products.

The plates should all be able to hold the same type of foodstuffs; if the category requires the plate to hold wet or greasy foods then the top surface of the plate must be water and grease proof regardless of the material from which the plate is made. The level of grease and/or water resistance would need to be tested (The Kit Test (Tappi T559)) and Permeability Test (ISO 16532-1,2,3). 
Typically, plates are held in one hand leaving the other hand free to access the food on the plate; therefore, a strength test is required to simulate this effect. An example of a test method to establish the strength of a plate, carried out at ambient temperature, can be seen below:

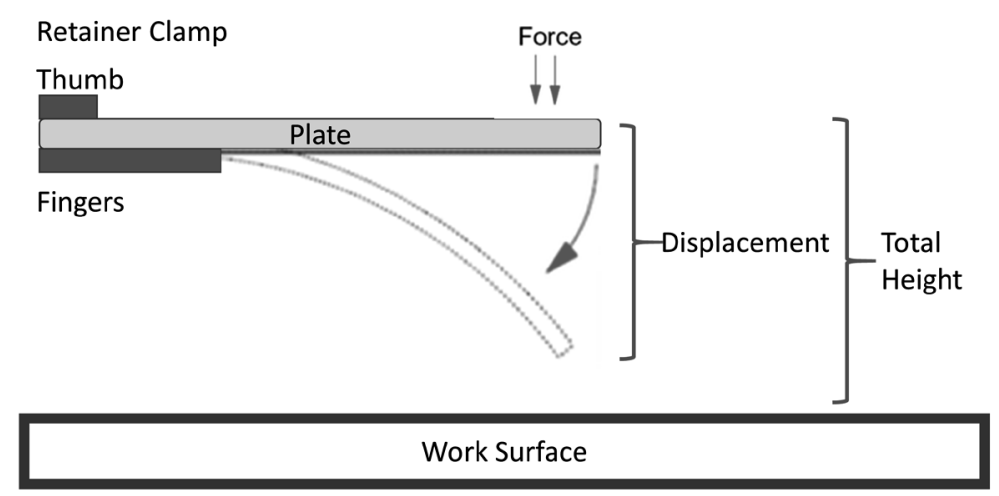

Figure 7.7: Example Plate Stiffness Testing Method

\subsection{Retainer Clamp}

The test can be presented as follows. The retainer clamp holds the plate horizontally. The part of the clamp on top of the plate represents the role of the thumb, it simply holds the plate horizontal. The part of the clamp underneath the plate represents the role of the fingers in supporting the plate and its contents. It is assumed that the fingers will extend from the edge of the plate towards the middle of the plate being in contact with $33 \%$ of the diameter of the underside of the plate, with this assumed distance being based on observations of candidates holding $22 \mathrm{~cm}$ diameter plates.

\subsection{Force}

To represent the force on the plate due to the weight of the food, a small bag is filled with a specific weight of plastic granules. This allows the weight to be spread and flattened out on the plate as would generally be the case with food, which can be seen in Figure 7.8 below. The weight can be varied as per the intended function of a specific plate category. The food is generally applied to the plate at the opposite side of the plate from the clamping thumb. The weight bag is applied to the opposite side of the plate from the clamp covering roughly $50 \%$ of its surface area. 


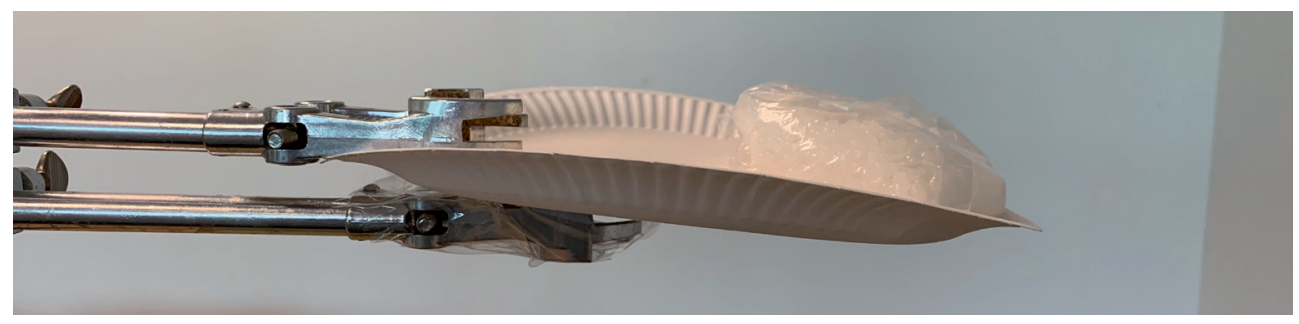

Figure 7.8: Position of Weight Bag representing Force on the Plate

\subsection{Displacement}

The distance between the outer edge of the plate, at the opposite side from the clamp, and the work surface top is measured. The weight bag is then placed on to the plate as described above. After a period of 45 seconds, this distance is measured again. This distance, taken from the original total height, gives the displacement of the plate due to the application of the force.

It is assumed that 45 seconds is enough time for the food to be totally applied to the plate and for the holder to realise that the plate is able to hold the food. It is possible that the weight bag will fall off the weaker plates within this period; these plates will then be removed from the category due to their lack of functional strength.

\subsection{Displacement PFR}

A method of establishing a PFR for the strength may then be to carry out this test on all plates in the primary category, listing the percentage displacement for each plate and establishing a graph of the standard deviation of this data. A rule could be established based on the choice of number of standard deviations from the mean.

While this may provide the basis for an objective PFR as regards strength, it should be considered that there will be a displacement value beyond which it will be impractical for the plate to function. Beyond this displacement value, the food will either spill from the plate due to its weight or the food will spill from the plate when the food is pierced by a fork or cut by a knife thus applying a further force. Plates that fail due to this weakness could be removed from the study of standard deviation.

This study of the standard deviation of only those plates that are strong enough to function provides a range within the chosen number of standard deviations. This could help in identifying those strong plates that may be too strong to be realistically considered disposable in the case of an FSD category of plates.

A study of twenty-three $22 \mathrm{~cm}$ diameter plates taken from the Dutch retail market were tested as described above. The mean displacement was $32.05 \%$ with a standard deviation of 8.64 , the spread being as follows: 
$\%$ Displacement 22cm Plates

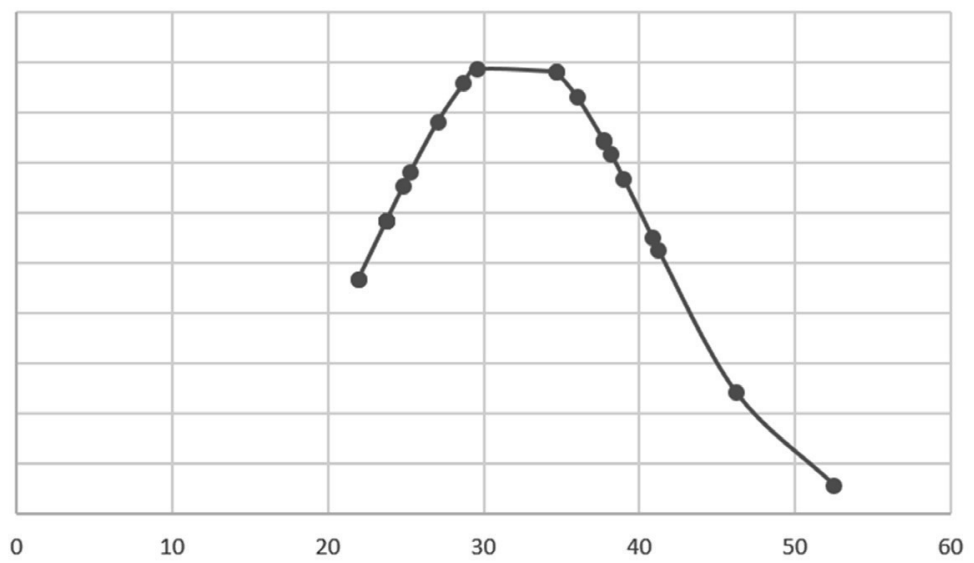

Figure 7.9: \% Displacement 22cm Plates

The choice of strength related PFR being based on the plates requiring to be within one standard deviation would exclude four outlier plates, three being too weak and one being too strong.

These outlier plates may be applicable to other categories of plates. The higher strength plate, judged to perform well in the bend displacement test, may be appropriate for a durable or re-usable plate category, if it is found not to meet a predefined definition of FSD.

Should the plate be specifically required for use with hot food, its strength could be established in the same manner as above, but with an appropriate quality bag containing a material at a predefined temperature which is left on the plate for the defined time.

\subsubsection{Other Examples of Properties included in PFR, as might relate to Beverage Cups}

Target functionality may also be defined in more subjective ways. Although surface "feel" or tactility of a product is largely subjective, it can also be established using instrumentation that measures the roughness and contours (Jenoptik 2014, Tactile Measurement).

How the cup sits in the mouth, against the lips, is often also referred to in the area of tactility. It is often reported that expanded polystyrene cups feel unpleasant against the lips. There are reported phobias of people having a fear of placing wood or paper in their mouths. While this could be considered in the FS, it will not be studied in this text. It may be clear that issues like these can be discussed and it can be decided that they are taken up in an extensive study, which would be carried out with the aspects that are shown which means: finding parameters that can be measured in an objective way and translating them to a test method. 
Another functionality factor might be the quality of the coffee foam layer which is so vital when serving a Cappuccino style coffee. The quality of the foam layer, as relates to the cups, depends upon the surface polarity and surface tension of the material on the inside of the cup. All paper cups have a polyethylene coating on their inside in order to make them watertight and for the cup walls to be heat sealable to one another during production. If a customer buys a brand printed cup, or a generic paper cup from another source, the performance of the coffee foam will not change. If the cup is coated with another material, there may be issues of surface polarity which will have to be studied if coffee foam retention is defined in the target PFR. It should be noted that this factor was not studied even though it is of importance to the coffee seller. If the foam collapses quickly in one cup compared to another, the cup is likely to be rejected by the coffee seller as this may affect their brand value.

Organoleptic considerations are vital as regards the coffee industry. Coffee derives its taste from a multitude of odours and flavours. Should these be modified due to the coffee cup substrate, this may render the cup unsaleable to professional coffee companies. Typically problems relating to odour are derived from two sources within an iconic paper cup firstly, the "paper" itself, which seems to be consistently identified by professional odour experts, and secondly, the ink (interview with A.Hoinkis, Douwe Egberts, 08/03/2012).

Like functionality considerations of a non-technical nature also exist in the form of product image to match brand value. It could be imagined that a Food Service operator offering expensive coffee might not wish to supply it in an EPS cup, even if this did have a lower environmental impact than a positively perceived higher impact cup. Consumer expectation of a product is also partially defined by what was paid for the product; this economic consideration might also be a factor in target like functionality specifications. These issues of product image and price are important and could be factors in defining PFR but they are not researched further in this study.

\subsubsection{Limits to PFR}

There are many factors that define the functionality of a product and it would seem fair that these be expressed within the PFR. It could be seen to be potentially destructive not to consider them. All products should be considered for a plate category if they are evidently a plate but where are the limits to the PFR?

It could reasonably be seen that excluding certain plates might be construed as bias and hence the need for a very clear definition of the PFR. Likewise, it is possible that the inclusion of plates that vary too much in functionality from the chosen product that defines the PFR could lead to a variety of equally unwanted effects in a comparative ECS, such as:

1. Complaints as to the lack of comparability of the items, hence the category risks becoming discredited.

2. Suppressing additional function and design in favour of environmental efficiency. 
3. The creation of a category in which outlier products have such a significant effect on the mean within a comparative ECS system, leading to the bunching of the remaining products and a significant reduction in the sensitivity or resolution of the category. This could then lead to the eco-innovation design changes of a specific product going unnoticed.

\subsection{A More Detailed Review of the Effect of PFR for a Category of Plates}

In order to understand the degree of significance of PFR choice and compliance, this subchapter researches the point in greater depth, the objective being to understand how these choices could affect the outcome of a comparative ECS in terms of relative product position. It is from these PFR choices that the study FU will be defined.

The following three categories will be identified for similar $22 \mathrm{~cm}$ diameter disposable plates as cited in Subchapter 7.4.1.1.4:

1. The full range of plates.

2. The full range of plates minus those excluded due to the lack of a greaseproof and waterproof layer, as identified through use of a kit test and permeability test cited in Subchapter 7.4.1.1 above. Plates 10 and 11 in Table 7.2 below are non-compliant to a PFR requiring a water and greaseproof plate to serve hot meals that could be moist or greasy.

3. The full range of plates minus those excluded due to the lack of strength as identified through strength testing cited in Subchapter 7.4.1.1 above. Plates 17 and 23 in Table 7.2 below are non-compliant to a PFR requiring a certain strength to hold a weight of meal.

The above three plate categories are listed in Table 7.2 below. The methods used to establish the Rank Order and Star Rating below follow the ReCiPe based approach described in Chapter 6; the Star Rating bandwidth is set at 10\%. A reference flow is a quantified amount of the product necessary for a specific product system to deliver the function described by the FS; in this study, single products will be compared. 
Table 7.2: Total Range of $22 \mathrm{~cm}$ Plates minus PFR Non-Compliant Plates

Total Category

- water/greaseproof

- water/greaseproof and - strength

\begin{tabular}{|c|c|c|c|c|c|c|}
\hline Ref. & Rank Order & Star Rating & Rank Order & Star Rating & Rank Order & Star Rating \\
\hline Plate-1 & 3 & 4.5 & 1 & 4.5 & 1 & 4.5 \\
\hline Plate-2 & 19 & 1.5 & 17 & 2 & 15 & 2 \\
\hline Plate-3 & 20 & 1.5 & 18 & 2 & 16 & 2 \\
\hline Plate-4 & 7 & 3.5 & 5 & 4 & 4 & 4 \\
\hline Plate-5 & 17 & 1.5 & 15 & 2 & 13 & 2 \\
\hline Plate-6 & 18 & 1.5 & 16 & 2 & 14 & 2 \\
\hline Plate-7 & 9 & 3 & 7 & 3 & 5 & 3 \\
\hline Plate-8 & 11 & 2.5 & 9 & 2.5 & 7 & 3 \\
\hline Plate-9 & 4 & 4 & 2 & 4 & 2 & 4.5 \\
\hline Plate-10 & 1 & 5 & \multirow{2}{*}{\multicolumn{4}{|c|}{ Failed Grease and Water Resistance Test }} \\
\hline Plate-11 & 1 & 5 & & & & \\
\hline Plate-12 & 12 & 2.5 & 10 & 2.5 & 8 & 3 \\
\hline Plate-13 & 22 & 0 & 20 & 0 & 18 & 0 \\
\hline Plate-14 & 23 & 0 & 21 & 0 & 19 & 0 \\
\hline Plate-15 & 5 & 4 & 3 & 4 & 3 & 4 \\
\hline Plate-16 & 14 & 2 & 12 & 2.5 & 10 & 2.5 \\
\hline Plate-17 & 6 & 4 & 4 & 4 & \multicolumn{2}{|c|}{ Failed Strength Test } \\
\hline Plate-18 & 15 & 2 & 13 & 2.5 & 11 & 2.5 \\
\hline Plate-19 & 16 & 2 & 14 & 2.5 & 12 & 2.5 \\
\hline Plate-20 & 10 & 2.5 & 8 & 3 & 6 & 2.5 \\
\hline Plate-21 & 21 & 1 & 19 & 1.5 & 17 & 1.5 \\
\hline Plate-22 & 13 & 2.5 & 11 & 2.5 & 9 & 2.5 \\
\hline Plate-23 & 8 & 3 & 6 & 3.5 & \multicolumn{2}{|c|}{ Failed Strength Test } \\
\hline
\end{tabular}

The yellow cells above indicate those plates whose Rank Order number has changed due to the removal of the two plates that failed the grease and water resistance testing from the Total plate category. These two plates, plates 10 and 11, were also the plates with the lowest ReCiPe endpoints total figures (see Appendix F) hence the Rank Order number of all the plates change. The blue cells represent those plates whose Star Rating has changed due to the change of the mean ReCiPe endpoints total figure for the category, having removed the two non-compliant plates from the Total plate category.

The orange cells above indicate those plates whose Rank Order number has changed due to the removal of the two plates that failed the strength testing from the Total plate category minus the plates that failed the grease and water resistance testing. The green 
cells represent those plates whose Star Rating has changed due to the change of the mean ReCiPe endpoints total figure for the category having removed the two non-compliant strength plates from the Total plate category as well as the plates that failed the grease and water resistance testing.

The Star Ratings move slightly due to the mean scores having altered due to the omission of the values for the products now excluded; because the previous top 2 plates have been excluded, ratings of remaining items are lifted slightly, and because of this, several move above a band boundary.

As non-compliant plates are removed from the category, the relative Rank Order of the remaining plates does not change, only their Rank Order number, as there is no change to their ReCiPe endpoints total value.

Removal of non-compliant product from the category has the obvious effect of changing the Rank Order number, and in some cases the Star Rating, of the remaining products in the category. Given this effect, it could appear necessary to ensure that the average functionality of the plates is achieved by all plates.

For example, all the plates in the above categories are made of plastic, plastic composite, plastic coated paperboard and in two cases uncoated paperboard. 91.3\% of all the plates have plastic in contact with the food and are grease and water resistant, while the two uncoated paperboard plates are not, representing $8.7 \%$ of all the plates. It would seem, in establishing PFR in the absence of stakeholders, that the grease and water resistance of the average plate should be part of the PFR.

If the goal is to identify the better scoring plates from a collection of existing plates taken from the Dutch retail market then this grease and water resistance may need to be represented in the PFR. It could be assumed that this grease and water resistance was an intended function of the absent plate manufacturer or importing stakeholder. Had it not been, then ten of the twelve paperboard plates would not have been coated, which adds additional cost to the product.

The two top scoring plates in both Rank Order and Star Rating are the uncoated paperboard plates which do not represent the grease and water resistant functionality of the category and their inclusion therein effects the relative ranking and rating of the compliant products in the category. Their inclusion could be seen as unfairly representing the relative ranking and rating of the other products in the category.

Their inclusion in the category depends on the goal of the study. Had the goal been to study a category of plates required to hold dry food, such as crisps or a sandwich, then their inclusion would have been relevant. 


\subsection{0ml Take-Out Meal Tray - A Study of a Category with Very Diverse Product Types}

Many of the product categories in this study cover products that are similar in their material types, manufacturing process and design, being categories of products of high resolution or high similarity. The choice of the take-out meal tray in this subchapter is to introduce a product that could be made from a wider range of different materials and manufacturing processes.

Take-out meals dispensed at the point of purchase are typically placed in manually lidded containers. The diversity of design types of such containers is considerable, some examples being:

1. coated carton board pot with a clip on lid in either plastic or carton board

2. coated carton board plate with a plastic dome lid

3. plastic container and separate plastic lid, injection moulded or thermoformed

4. plastic container with a hinged plastic lid

5. hinged EPS container

6. folded and glued coated carton board tray with lidding closure flaps

7. pot style coated carton board container but with lidding closure flaps

8. aluminium foil container with a foil laminated carton board lid

9. moulded fibre press formed hinged lid container

The permutations in terms of materials, coating and process is considerable in such a diverse range of meal tray and lid types. 

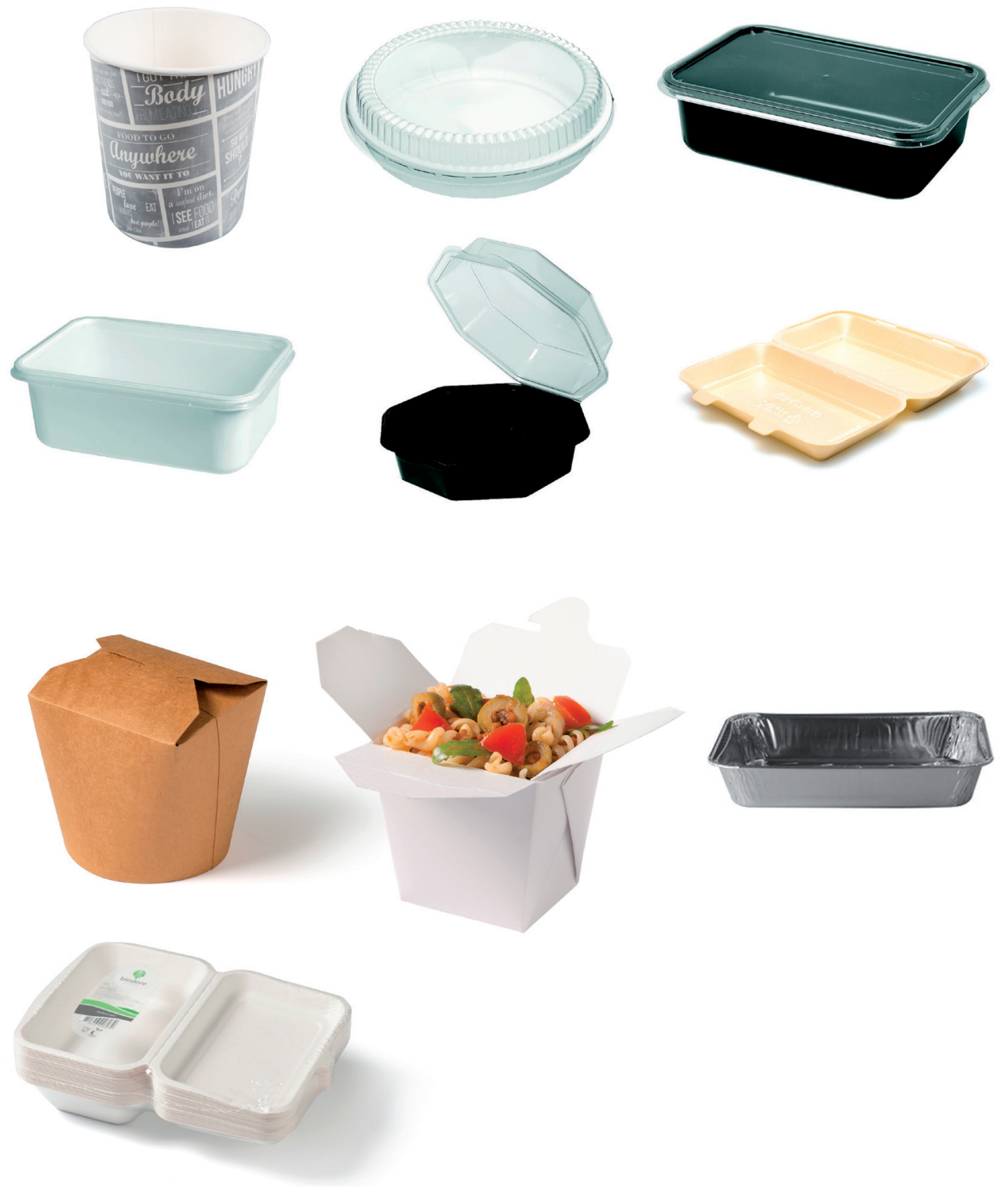

Figure 7.10: Examples of Take-Out Meal Trays 


\subsubsection{0ml Take-Out Meal Tray - Functional Unit}

In the case of the plates in Subchapter 7.5, there were three basic FS applied to the FSR, notably grease/water resistance, strength and the requirement for the plates to be of a certain size. In the case of the take-out meal tray, there is the capacity definition as well as other potential additional FS, such as:
1. insulation
2. leak-proof
3. printable
4. microwavable
5. ovenable
6. integrated lid
7. strength and stability based on meal type (soup, fries, rice, etc)
8. vented (as required for items such as fries, to avoid softening)
9. brand image or perception
10. transparent lid
11. recyclable at End-of-Life

This list is not exhaustive.

Methods to test these FS objectively should be established. Some are immediately apparent, such as integrated lid, while others, such as insulation as was described in Subchapter 7.4.1, will require testing. Tests for leak-proof, venting and stability, derived from the requirement of differing meal types, could also be objectively established.

Should printable be chosen as a FS, it could be assumed that a simple study would indicate that it is technically possible to print all tray types. Certain tray types are not typically printed and hence will not be available as printed even if it is technically possible. With no stakeholder input, knowledge of the processes typically found in certain tray manufacturers in this specific market is required. The extent to which this is objective could be questioned.

Should a visual FS be required to comply with the brand or message the take-out operator wishes to reflect, this could be established as an objective FSR. Such an FSR may be the requirement for a paper and/or board type product in place of a synthetic plastic type product. This choice is subjective but compliance to it could be objective, depending on the nature of the choice.

To what extent should additional FS be considered in a study based exclusively on a primary FS? If the function is simply to carry $750 \mathrm{ml}$ of food, all of the above meal trays meet that function but with a range of additional FS. It could be assumed that the additional FS in the $750 \mathrm{ml}$ trays will not be considered in the FSR, this further proving the importance of clearly defining the FS required of the trays to be compared. 
A centralized classification of FSR per product category could be imagined. In the case of automobile classification ("How are vehicle size classes defined?", U.S. Department of Energy, Retrieved 22 April 2012.), all cars function to carry passengers but they are still divided into classes to represent additional FS. How realistic this approach would be for all products is questionable.

The greater the resolution of the category, due to highly defined FSR, the smaller the category will become. In the case of the above $750 \mathrm{ml}$ meal trays, only the aluminium tray is ovenable $\left(250^{\circ} \mathrm{C}\right)$, with no disposable options other than aluminium trays meeting this FS. A further $750 \mathrm{ml}$ aluminium tray category would have to be established.

\subsection{Methods to Establish PFR to Categorise a group of Apparent Like Functionality Products}

A method for establishing PFR and FU from a group of pre-existing products of apparent like functionality in the absence of manufacturing or importing stakeholders of the individual product would need to be researched. Some examples are given below; this list is not exhaustive and further research may identify more methods.

\subsubsection{Goal defined Category PFR}

It could be that a study goal defines the PFR. The goal may simply state the FU to be a number of "meal servings" as seen above in Figure 7.3. Alternatively, a tighter description of function could be given, such as a "22cm diameter water and grease resistant plate able to hold $200 \mathrm{~g}$ of food when carried with one hand".

\subsubsection{Scope defined Category PFR}

It could be that the scope of the study influences the PFR. The above $22 \mathrm{~cm}$ plates described in Subchapter 7.4.1.1.4 above were stated as being from the Dutch retail market. If the scope of the study was to broaden to take in other markets, such as the Dutch Food service market, this may influence the PFR. The inclusion of these additional Food service plates may introduce further FS and influence the average functionality of the plates.

\subsubsection{CPA defined Category PFR}

PEFCR or EPD require the use of Classification of Product by Activity (CPA) to guide comparative product choice; however, this would not seem a precise enough definition with regard to FSD. In the paper by Finkbeiner, M., 2014, this CPA approach is criticized, citing "for many products the identification of a suitable code is not a straightforward task" (p. 268).

The CPA definition as used for paper plates does not cover grease or water resistance; in the equivalent plastic plate this functionality would be inherent in the material. FSD categories are likely to contain products of differing basic material types. PEFCR permits 
the use of multiple CPA codes within the same category (PEF Guide 2012, p. 15) to help accommodate this fact but this may not always result in an exact enough category definition. It may not achieve the stated PEFCR rule that "comparative products must be identical" (ISO 14025: 2006).

plastic plates: CPA code:222923

Tableware kitchenware other household articles and toilet articles of plastics paper plates: CPA code:172213

Suppliers of trays, dishes, plates and cups and the like, of paper or paperboard

\subsubsection{Label defined Category PFR}

FSD outer primary packaging may be printed with a description of the functionality which could provide guidance as to the stakeholders intended function of the product.

An example of a pre-defined category could be seen to be the $180 \mathrm{ml}$ vending cup. Vending machines require cups of a very specific rim diameter in order to function, so these cups are sold clearly labelled as "180ml vending cups". The cups may be made of various different materials such as PS or PE coated board. Any critique of the category choice is addressed by the need for a very clear definition of the product on the label (to avoid jamming vending machines with other cup types).

In the case of the above studied $22 \mathrm{~cm}$ plate category, some of the plates came in packaging on which it was printed that they could be used for hot, wet and greasy foods. While other plates, with the same functionality, did not have packaging printed with this statement. This may indicate the necessity to test all plates for their resistance to hot, wet and greasy foods.

\subsubsection{Categories PFR based on the Function of the Demonstration Product}

If a category is being established against which to compare a specific demonstration product, it could be possible to fully analyse the FS of this demonstration product. The results of this analysis could then be used to define the PFR to which alternative products must comply.

\subsubsection{Category PFR based on the Average Functionality of the Primary Category}

As was stated above in the study of $22 \mathrm{~cm}$ plates, all the plates in the Primary Categories are made of plastic, plastic composite, plastic coated paperboard and in two cases uncoated paperboard. 91.3\% of all the plates have plastic in contact with the food and are grease and water resistant, while the two uncoated paperboard plates are not, representing $8.7 \%$ of all the plates. This could indicate that the PFR needs to require compliant plates to be grease and water resistant. 


\subsubsection{Category PFR based on Territory Considerations}

ISO 14025 does not state that a territory specific PCR needs to be developed although any territory has to be specified. EPD are largely geographically restricted to the host country of the program operator (Ingwersen, W.W., et al., 2012). In this study the territory is the Netherlands; the territory could have been set as The Benelux or the European Union. The global nature of FSD might drive a claim maker, such as a product supplier, to develop a category based on a larger territory in order to make their comparative ECS rated goods more exportable.

While it could appear more advantageous and efficient to develop a single EU wide category, this may influence the relative position of an item within a comparative ECS compared to a country level territorial rule. It could also be questioned as to how relevant an EU perspective is with regard to the actual FSD products used in a specific EU member state. It could be possible that a top scoring product in an EU based study is not on offer in a specific member state.

Waste management systems can vary by country and this may influence the specifications of products in that country as regards their compliance to that country's waste management system. The type of waste management system will also influence the end-of-life scenario calculations in the product LCA.

Recent consideration by the EU and European national governments regarding the banning or taxing of certain FSD could influence the range of functionality in a national FSD category.

\subsection{Chapter 7 Conclusions and Discussion}

In the above $22 \mathrm{~cm}$ diameter plate study, plates that approximately appear to fit the same $22 \mathrm{~cm}$ disposable plate category were studied. This type of basic category definition of a $22 \mathrm{~cm}$ plate might appear sufficient for setting the PFR and FU for a comparative ECS of FSD. However, as the product FS definition is made tighter or stricter as regards water and grease resistance and strength, the Rank Order number and the Star Rating of the products within the category change.

The extent to which a product category must be defined for a comparative ECS, made in the absence of the product stakeholders, would appear to require to be exacting in order to be seen as unbiased and credible. ISO 14025:2006 states that "the function, technical performance and use of comparative products must be identical".

The $22 \mathrm{~cm}$ plate is a relatively straightforward product to study. Other FSD, such as coffee cups and cutlery categories, will introduce ever more and exact category functionality rules such as levels of insulation or strength, as mentioned in Subchapter 7.4 above. These are certainly not FS defined in CPA. 
It could be said that the more exact definition of a FU could have to be developed based on product testing as well as general product FS. This FU could be proposed by the claim maker but it could be seen as subjective with no formal definition to support it, such as CPA.

The exact FS of the product requires defining, and its qualification for inclusion in the category might require significant testing. This testing could be seen to be an objective assessment of compliance to a subjective FU.

Any changes in the definition of the category or product specification or functionality may lead to different results as regards the positioning of the product within a comparative ECS.

It can be questioned at what point the generic functionality of a product is acceptable to a category definition in which products with additional functionality exist. The PFR and FU can define the narrowest possible functionality or an overarching generic functionality and if the latter is chosen the question is what the effect on stifling product eco-innovation, design and creativity would be? As Ingwersen stated: "What level of resolution is necessary to capture the desired effect?" (Ingwersen, W.W., et al., 2012).

The ISO 14025:2006 statement that "the function, technical performance and use of comparative products must be identical" is of concern since it is possible that products with a like functionality may have a technically different performance. This statement may be too strict, as the objective of a product comparative study is to establish product differences. It could be questioned that this strict rule could also be problematic if all product stakeholders were available during the formation of a category PFR.

Excluding products that do not meet the functional requirements for a particular category of FSD products in a study could make such studies more valid. It could be concluded that it is necessary to do this, as the inclusion of non-compliant products may invalidate such a study.

Figure 7.11 below graphically represents the definition of a final category of PFR compliant products, starting from the primary category and ending in the final category used within a study. 


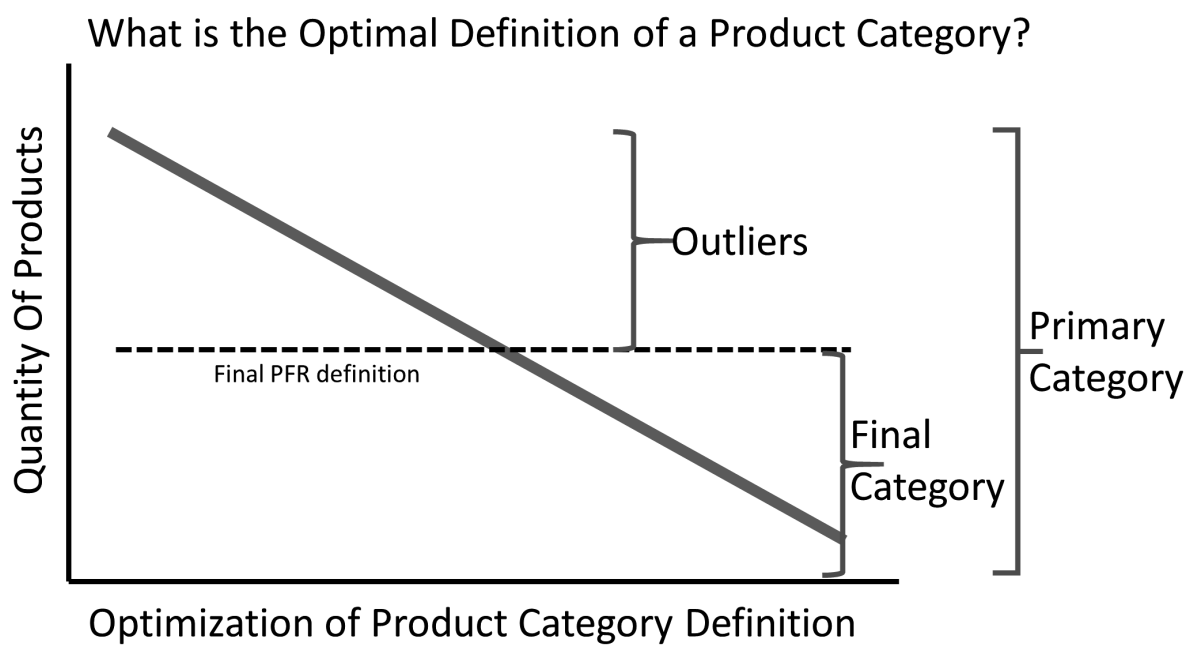

Figure 7.11: Definition of the Final Product Category

In answering RQ 2a, "How should a functional specification be addressed for a comparative study of a particular category of FSD products?", Chapter 7 has introduced the need for testing or analysis to establish like functionality on the basis of a FS in the absence of product stakeholders.

In Chapter 8, this analysis is further evolved to establish the material composition of a product and its category member products. 


\section{Chapter 8}

FSD Material Composition Identification for LCA Input 


\subsection{Introduction}

In Chapter 4, it was identified from PEFCR and EPD that all resource use and constituent substances in a product shall be included, stating that data should include all known input. The question is to what degree these resources are known and what the route is to establishing them if no materials data is available from the product manufacturing stakeholder.

This chapter addresses research question $2 \mathrm{~b}$ :

RQ 2b. How should the material composition and processing details be determined for each product included in a comparative study?

It is required that any product LCA study should take account of the product composition and component weights. This product composition and component weight accounting depends largely on the data obtained from industrial sources and these sources "cannot be relied upon blindly" (Ayres, R.U., 1995, p. 220). In the Ayres (1995) paper it was stated that "detailed examination reveals glaring internal inconsistencies" with stakeholder sourced data. This point is further taken up in Baker (2009) as regards the reliability of LCA conclusions in the face of increasing uncertainty or trustworthiness of data from an ever more global market. It further cites that "Differences may arise from lack of knowledge about what material will be used in the system" (Baker, J. W., et al., 2009).

Chapter 4 identified that transparency of data is imperative to a credible comparative ECS. If there is no cooperation between the stakeholder parties, no information will be forthcoming. In practice, as was identified in the Chapter 5 questionnaire, this is a likely possibility.

Further research in this chapter will address the following:

1. The extent to which a product material composition may deviate from what it might visibly or initially be identified as.

2. How material composition can be established and what LCA input data it influences.

3. The extent to which the knowledge of the accurate composition of a product influences its position within a rank order and banded scale comparative ECS, compared to a visual or more superficial identification of the materials. 


\subsection{Materials Identification}

Due to the high contribution that raw material choice makes to the environmental impact of an item (Grant, T., 2009) (van der Harst-Wintraecken, E. J., 2015), this study seeks to establish if it is vital to accurately and independently establish the component materials within an item, both qualitatively and quantitatively. Accurate raw material identification does not just identify the raw materials used but should also aid in identifying the associated conversion processes and, to a certain degree, the impact implications related to the end-of-life scenario.

It could appear unrealistic to expect manufacturers of competing items to divulge their material composition since this can be part of their business model. When the manufacturing stakeholder of a product is absent, its product material composition may be difficult to identify. This might make it difficult to carry out a comparable LCA without the availability of a materials identification laboratory and product knowledge to take actions that are technologically relevant to the sector (Baitz, M., et al., 2012).

The qualification and quantification of the material components for input to a product LCA is cited as both time consuming and costly (van Berkel, R., 2002) (O'Neill, T. J., 2003) (Weitz, K., et al., 1999).

In the 1999 SETAC report (Weitz, K., et al., 1999), it is cited that scoping must be addressed "before any data are collected". This is understandable given the current approach to product inventory collection as described in Chapter 5, with its cost and time implications, it could be seen to be too cumbersome to be part of the scope process. Although this may risk overlooking inventory that, had it been known in advance, would have influenced the scope definition. Time efficient materials identification, through the use of laboratory instrumentation and product knowledge, could influence the chosen scope of a study. This point should be researched.

With the justice system being able to pass sentence "beyond reasonable doubt" based on evidence derived from instrumentation and laboratory based identification (Gentile, N., et al., 2015), it may be questioned if a similar approach could also be taken for the materials composition qualification and quantification of a product, the derived data then being used as product economic inventory data for input in an LCA study.

\subsubsection{Instrumentation Requirements}

The identification of components and their weight within a product requires instrumentation that identifies the molecular composition of the product. The use of this instrumentation is to establish objective materials data in a time efficient manner and to maximize the quality of the data input into the LCA study. This data may also be of value in defining the scope and product category rules. 
Examples of instruments that could be used to establish the physical and mechanical properties of like functionality products, as described in Chapter 7, and the identification of material composition as input for LCA, can be seen in Table 8.1 below. This list is not exhaustive and is purely given as an example. There could be some alternative choices of instruments and some additions to support yet more detailed investigations. The set of instruments listed allowed permitted measurements needed for the research in this study.

Table 8.1: Instrumentation Used to Support ECS

\begin{tabular}{|c|c|}
\hline Instrument & Use \\
\hline Weighing Scales & high accuracy weighing \\
\hline Micrometer & high accuracy thickness \\
\hline Vernier Calipers & measuring dimensions \\
\hline GSM Cutters & for material weight per square metre \\
\hline Rulers & measuring dimensions \\
\hline Density Instrument & density of items of all shapes \\
\hline Universal Testing Instrument (UTI) & for like functionality testing \\
\hline Various UTI jigs & for like functionality testing \\
\hline Melt Flow Index & for improved composite identification \\
\hline XRF & for inorganic identification \\
\hline FTIR & for organic identification \\
\hline Raman Microscope & for organic identification of a specific part \\
\hline Surface temperature Thermometer & for insulation like functionality studies \\
\hline Infra-Red Camera & for insulation like functionality studies \\
\hline Microscope & for multi-layer and foam/fill studies \\
\hline Microtome & to support the microscope preparations \\
\hline
\end{tabular}

\subsubsection{Materials Identification}

A description of the methods and approaches to identify materials composition in FSD is explained in this subchapter. This is a non-exhaustive list and many other approaches are possible.

In a white polypropylene (PP) product made of a PP composite containing $50 \% \mathrm{CaCO}_{3^{\prime}}$ an example addition of $2.5 \% \mathrm{TiO}_{2}$ as white colour additive equates to $10.55 \%$ of the total product ReCiPe figure of the raw materials in the PP composite item based on LCIA data from Ecoinvent v3.4 (ReCiPe $2008 \mathrm{H}$ endpoints total). Had the LCA operative not been aware of the $2.5 \% \mathrm{TiO}_{2}$, their starting $\mathrm{ReCiPe}$ figure would be incorrect by $10.55 \%$. Had they not been aware of the $\mathrm{CaCO}_{3}$ and the $\mathrm{TiO}_{2}$ their study would be incorrect by $46.79 \%$. Omission of substances in the inventory data collection can have an effect on impact results (Van der Harst-Wintraecken, E. J., 2015). 
Table 8.2: Current and Detailed Materials Identification

\begin{tabular}{l|c|c}
\cline { 2 - 3 } What the human eye sees (Current) & $100 \% \mathrm{PP}$ & \multicolumn{1}{c}{ Materials only } \\
\hline \multirow{3}{*}{ What instruments measure (Detailed) } & $47.5 \% \mathrm{PP}$ & 0.30378 \\
\cline { 2 - 3 } & $50 \% \mathrm{CaCO}_{3}$ & 0.00378 \\
\cline { 2 - 3 } & $2.5 \% \mathrm{TiO}_{2}$ & 0.68239 \\
\hline Total Instrument Measured (Detailed) & $100 \%$ & 0.16165 \\
\hline
\end{tabular}

It should be noted that the example in the above table covers only the ReCiPe endpoints total of the materials and not the whole life cycle. The identification of the non-PP materials above then allows the LCA operative, with the relevant technology experience and knowledge, to identify that further conversion processes need to be added that apply to these two non-PP materials and their inclusion in the composite. The associated additional transports and end-of-life implications may also become clear.

The choice of a white PP product with $\mathrm{CaCO}_{3}$ mineral filler and $\mathrm{TiO}_{2}$ white colour additive was specifically chosen in this case due to the fact that both the mineral and the white colour additive contribute to making the naturally milky PP material white. It might not be evident from a non-instrumentation analysis as to their inclusion in the product and what the by-weight amount of either additive would be in the product, although it is evident that some type of additive is making the product white.

This laboratory approach gives a clear picture of the primary materials. However, identification and quantification of recycled content in certain materials remains a significant challenge. It may be that the percentage of recycled content within the item cannot be confirmed.

The presence of contaminants not typically present in virgin materials could be taken as an indication of the presence of recyclate. A variety of other techniques could be used, such as a study of the rheology or a match against a bespoke FTIR library of multiple percentage recycled materials. Study of the Melt Flow Index can also help to identify potential recycled material (ASTM D-1238: ISO 1133). Surface oxidation can also be measured by FTIR using the Surface Oxidation Index based on the intensity ratio between the $\mathrm{C}=\mathrm{O}$ stretch over the $\mathrm{C}-\mathrm{H}$ vibration (Andersson, $\mathrm{T}_{\text {, }}$ et al., 2003) but this is only relevant for the surface of any layer within the product and not the total product. Microscope analysis of papers and boards may also be used to identify recycled content. While these approaches may indicate the presence of recyclate within a product they will certainly not be a source of its quantification.

$X$-ray fluorescence (XRF) is used to identify the inorganic elements (Jenkins, R., 1999) (Leng, Y., 2009) (Riise, B. L., et al., 2000) (Mans, C., et al., 2007) (Wolksa, J., 2005) within 
the material of a product. The result is both qualitative and semi quantitative. The quantification is further established using density instrumentation.

Fourier transform infrared spectroscopy (FTIR) is used to qualify the organic group (Garton, A., 1992) (Leng, Y., 2009) (Eisenreich, N., et al., 2006) (Gulmine, J. V., et al., 2002) (Camacho, $W$., et al., 2001) bonded to the inorganic element. This is best described in an example. Assume an XRF analysis of a cup identifies an amount of calcium only, with the remainder being "balance". The technician, with packaging technology experience, would assume this would likely be calcium carbonate $\left(\mathrm{CaCO}_{3}\right)$. However, they could only be certain once they had established the distinctive "carbonate" wave-number peaks using FTIR.

Using stoichiometric chemistry, the total loading of the $\mathrm{CaCO}_{3}$ within the items raw material can be calculated, this then being confirmed by measuring the density of the item and comparing that with a calculation of the percentage $\mathrm{CaCO}_{3}$ in the $\mathrm{PP}$, based on the Rule of Mixtures - see Figure 8.1 and Table 8.3 below.

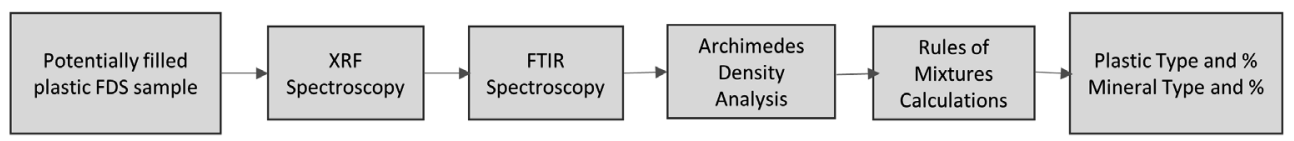

Figure 8.1: Approach to identify the Percentage Weight of $\mathrm{CaCO}_{3}$ in a PP FSD

Table 8.3: Calculation of Percentage Weight $\mathrm{CaCO}_{3}$ in a PP FSD

\begin{tabular}{l|c}
\hline XRF Detects & $10 \% \mathrm{Ca}$ \\
\hline FTIR Detects & Carbonate \\
\hline Molecular weight of $\mathrm{CaCO}_{3}$ & 100 \\
\hline Atomic weight of $\mathrm{Ca}$ & 40 \\
\hline $100 / 40=$ & 2.5 \\
\hline $10 \% \mathrm{Ca} \times 2.5=\mathrm{CaCO}_{3}$ percentage & $25 \%$ \\
\hline FTIR Detects & Isotactic PP \\
\hline Density of filled part & $1.086 \mathrm{~g} / \mathrm{cc}$ \\
\hline Rule of Mixtures $\mathrm{CaCO}_{3}$ in PP by wt & $25 \%$ \\
\hline
\end{tabular}

As XRF is the primary qualitative and semi quantitative determinant (the FTIR simply confirms the presence of carbonate), it is important to establish the by-weight quantity of Calcium Carbonate content in the composite. To achieve an accurate result, the density of the product can be measured using the Archimedes Principle and a rule of mixtures calculation applied using the cited component densities. 
Should two elements be identified, using XRF, at the high levels necessary for fillers, e.g. Magnesium and Silicon, the likely filler is talc, $\mathrm{Mg}_{3} \mathrm{Si}_{4} \mathrm{O}_{10}(\mathrm{OH})_{2}$. The same stoichiometric approach could be taken for talc as for calcium carbonate but starting first with one element then with the other in order to establish the highest loading of talc; any residual element amount could then have to be studied as another potential compound such as $\mathrm{SiO}_{2} . \mathrm{SiO}_{2}$ may be an impurity in the original mineral as these minerals are often, by their very nature, impure materials, or it may have been added as an anti-block additive for example.

Due to the relatively non-homogenous nature of a polymer composite, it could be required to measure the density of the product under study, by determining the weight and volume of the product in order to confirm the filler loading, as the XRF analysis is not quantitatively accurate in terms of percentage by weight of a specific element, due to the thickness of the sample which is an important parameter for XRF analysis (Nakano, K., et al., 2003). A density weighing scale is ideal for this purpose, such as for measuring the density of an irregularly shaped piece of cutlery. With thermoformed cups density measurements can be carried out on the extruded sheet using $\mathrm{gsm}\left(\mathrm{g} / \mathrm{m}^{2}\right)$ cutters, providing the material gauge is consistent.

A higher mass sample is not always directly available when measuring FSD as they tend to be made of thin wall materials. As can be seen in the cup study in Table 8.4, the cup wall exhibits a lower percentage of $\mathrm{Ca}$ than the base and rim. Hence, to aid density accuracy, the sample could be melted down at a controlled temperature, using an MFI instrument, so as not to burn off the organics. This produces a higher mass sample for density analysis purposes; however, it would be vital to establish that no voids have developed within the sample. See the cup in Figure 8.2 below reduced down to a higher mass sample:

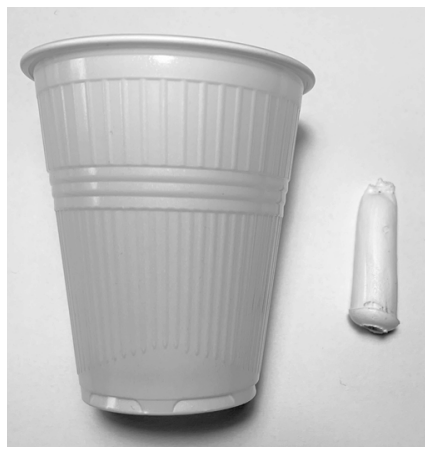

Figure 8.2: A Melted Higher Mass Sample of Plastic Cup

Some products in the FSD category are very light weight with a low density. To overcome the challenge of component quantification within such products, the density could be established using a solution with a lower density and a lower surface tension than water, like ethanol. This lower surface tension reduces the chance of bubbles distorting the density result. 
Using XRF, it is possible to see that filled polymeric materials can vary in their homogeneity due to ineffective compounding and/or extrusion, as per Table 8.4. The dispersion of the filler/additive may be poor, or the processing may result in uneven distribution. Hence there is a need to measure the density of the whole product rather than just a part of it where possible.

Analysis of the following PS vending cup (see photo in Figure 8.3 below) indicates the problem of quantifying the elemental content, due to the inhomogeneity of the material, and this can be seen from the XRF results. The photograph on the left shows the full body of the cup, the middle photograph shows the base of the cup and on the right the rims, walls and bases each grouped together separately.

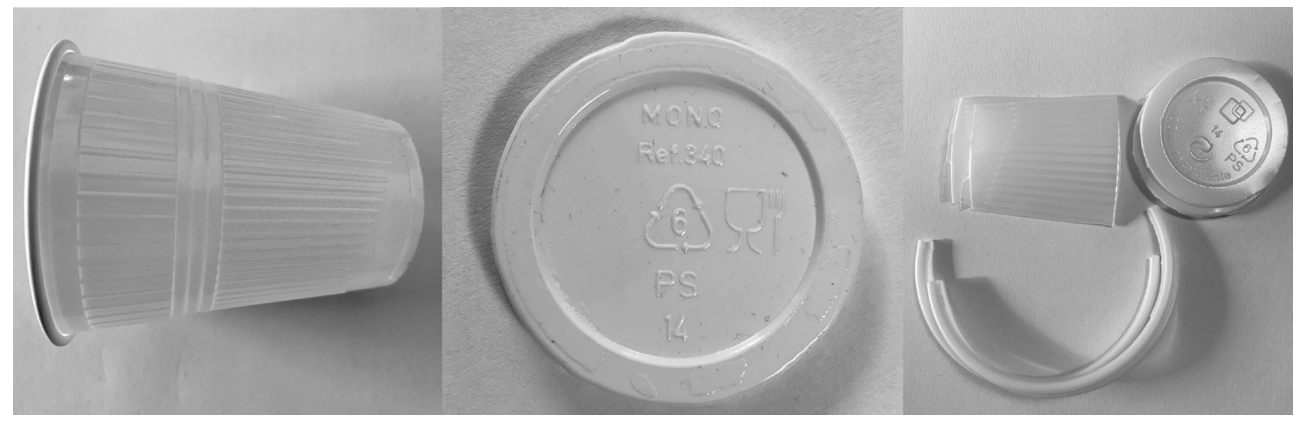

Figure 8.3: Sample Preparation for XRF study of Cup Rim, Base and Wall

The sample preparation involved 12 cups, the full length of the cup visible in the above left picture in Figure 8.3. The top rims and bases were carefully removed, see above right picture in Figure 8.3. The walls were cut vertically into four equal width strips. Like items were stacked to get the thickest bundles, ensuring that they fully covered the XRF objective. The middle picture in Figure 8.3 above shows the cup base.

Below in Table 8.4, a study using XRF identifies that filled polymeric materials can vary in their homogeneity due to ineffective compounding and/or extrusion. 
Table 8.4: Distribution of Elements Throughout the Formed Cup

\begin{tabular}{|c|c|c|c|c|c|c|c|c|}
\hline & $\begin{array}{c}\text { Remainder, } \\
\text { mostly organic }\end{array}$ & $\mathbf{w}$ & $\mathbf{v}$ & Zn & $\mathrm{Ti}$ & $\mathrm{Ca}$ & $\mathbf{S i}$ & Cl \\
\hline \multicolumn{9}{|l|}{ TOP RIM } \\
\hline POSITION 1 & 86.71 & 0.011 & 0 & 0.021 & 1.37 & 11.78 & 0.063 & 0.018 \\
\hline POSITION 2 & 88.07 & 0.013 & 0 & 0.019 & 1.20 & 10.06 & 0.068 & 0.016 \\
\hline POSITION 3 & 88.20 & 0.014 & 0.008 & 0.020 & 1.17 & 10.51 & 0.053 & 0.016 \\
\hline POSITION 4 & 86.62 & 0.019 & 0.009 & 0.020 & 1.38 & 11.80 & 0.109 & 0.023 \\
\hline Average & 87.40 & 0.014 & 0.004 & 0.020 & 1.28 & 11.04 & 0.073 & 0.018 \\
\hline \multicolumn{9}{|c|}{ TOP OF THE WALL } \\
\hline POSITION 1 & 91.62 & 0 & 0.006 & 0.012 & 0.786 & 7.54 & 0 & 0.008 \\
\hline POSITION 2 & 91.61 & 0 & 0.004 & 0.012 & 0.793 & 7.54 & 0.025 & 0.008 \\
\hline POSITION 3 & 91.55 & 0 & 0 & 0.012 & 0.795 & 7.59 & 0.027 & 0.008 \\
\hline POSITION 4 & 91.58 & 0 & 0.004 & 0.012 & 0.798 & 7.56 & 0.026 & 0.009 \\
\hline Average & 91.59 & 0 & 0.004 & 0.012 & 0.793 & 7.56 & 0.020 & 0.008 \\
\hline \multicolumn{9}{|c|}{ HALF WAY DOWN THE WALL } \\
\hline POSITION 1 & 90.50 & 0 & 0.005 & 0.014 & 0.911 & 8.53 & 0 & 0.01 \\
\hline POSITION 2 & 90.47 & 0 & 0.005 & 0.014 & 0.912 & 8.55 & 0.025 & 0.01 \\
\hline POSITION 3 & 90.46 & 0 & 0.006 & 0.014 & 0.910 & 8.56 & 0.030 & 0.01 \\
\hline POSITION 4 & 90.43 & 0 & 0.007 & 0.014 & 0.917 & 8.58 & 0 & 0.01 \\
\hline Average & 90.47 & 0 & 0.006 & 0.014 & 0.913 & 8.56 & 0.014 & 0.01 \\
\hline \multicolumn{9}{|c|}{ WALL NEAR THE BASE } \\
\hline POSITION 1 & 90.28 & 0.004 & 0 & 0.014 & 0.93 & 8.71 & 0.038 & 0.009 \\
\hline POSITION 2 & 90.26 & 0 & 0.006 & 0.014 & 0.933 & 8.73 & 0.034 & 0.009 \\
\hline POSITION 3 & 90.28 & 0 & 0.005 & 0.014 & 0.928 & 8.72 & 0.033 & 0.009 \\
\hline POSITION 4 & 90.26 & 0 & 0.008 & 0.014 & 0.926 & 8.74 & 0.037 & 0.008 \\
\hline Average & 90.27 & 0.001 & 0.005 & 0.014 & 0.929 & 8.73 & 0.036 & 0.009 \\
\hline \multicolumn{9}{|c|}{ MIDDLE OF THE BASE } \\
\hline POSITION 1 & 87.14 & 0.010 & 0 & 0.020 & 1.31 & 11.47 & 0.029 & 0.011 \\
\hline POSITION 2 & 86.86 & 0.011 & 0.009 & 0.020 & 1.34 & 11.70 & 0.034 & 0.012 \\
\hline POSITION 3 & 86.80 & 0.008 & 0.013 & 0.021 & 1.35 & 11.74 & 0.052 & 0.012 \\
\hline POSITION 4 & 86.75 & 0.009 & 0 & 0.020 & 1.36 & 11.79 & 0.044 & 0.012 \\
\hline Average & 86.89 & 0.010 & 0.006 & 0.020 & 1.34 & 11.68 & 0.040 & 0.012 \\
\hline
\end{tabular}


It may be wise for further studies to be carried out to understand the displacement of minerals in homogeneous polymeric compounds when they are formed into products. From the above table, it would appear that the rim and the base (during thermoforming the least stretched part of the cup) most reflect the true mineral loading of the polymer compound. However, the use of an MFI instrument to melt down the complete cup into a high mass sample would likely produce the most accurate reading when coupled with a density test (Bag, D. S., et al., 2003). It is of course vital to ensure that the melted sample contains no voids. Voids can be reduced by placing the sample in an oven and submitting it to a temperature close to its melt temperature for several hours.

To measure density the ASTM D792-00 approach has been taken:

Density $=\frac{W_{a}}{W_{a}+W_{w}-W_{b}}$

$W_{a}=$ weight of specimen when hung in air

$W_{w}=$ weight of the partially immersed wire holding the specimen

$W_{b}=$ weight of the specimen when immersed fully in distilled water along with the partially immersed wire holding the specimen.

When making very exact measurements, the temperature of the distilled water must be taken into account. Materials with a density below $1.0 \mathrm{~g} / \mathrm{cm}^{3}$ cannot be measured using water since they will float (e.g. pure unfilled polymers such as LDPE, HDPE, PP). However, items lighter than water can be held under water by a pre-weighed ballast in order to establish volume. Alternatively, they can also be measured in a solution with a lower density than water, like ethanol which has a density of $0.789 \mathrm{~g} / \mathrm{cm}^{3}$.

It is important to bear in mind that polymers used for cups are hydrophobic and difficult to wet, so bubbles can be trapped on the surface. A few drops of detergent in the distilled water will help the wetting. Ethanol also has a lower surface tension than water and this can eliminate the issue of bubbles.

Since the density of the fillers to be identified are very similar and very far from the density of the unfilled polystyrene, a density measurement will be sufficient to confirm the presence and approximate content of filler, sufficiently supporting the XRF/FTIR results. This, along with a potential ash test result, not available for this study, or the joint MFI and XRF high mass study, can be used to convince a doubting party, whose product is listed in a comparative ECS, that their filler levels have been identified and quantified, should this be necessary.

Appendix $G$ provides a list of the common polymers with filler levels from $1 \%$ to $55 \%$ by density. This aids the density instrument operative in quantifying the filler level in the polymer sample. 
It should be noted that the results of density measurements and XRF quantification can be distorted by the application of density-reducing chemical foaming agents or cavitating agents as being used for BOPP films. Intentional inclusion of gases into the material is visible using microscopy to identify voids as in Figure 8.4 below. The sample should then be melted to form a block without air inclusions prior to the XRF and density study.

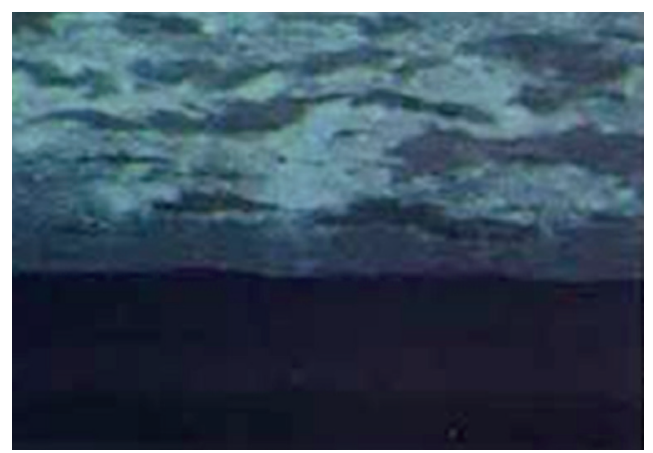

Figure 8.4: Multi-Layer Cup Wall showing Voids in the Middle Layer

It should also be noted that void shape and size and mineral shape and size can be determined using microscopy (Sawyer, L., et al., 2008).

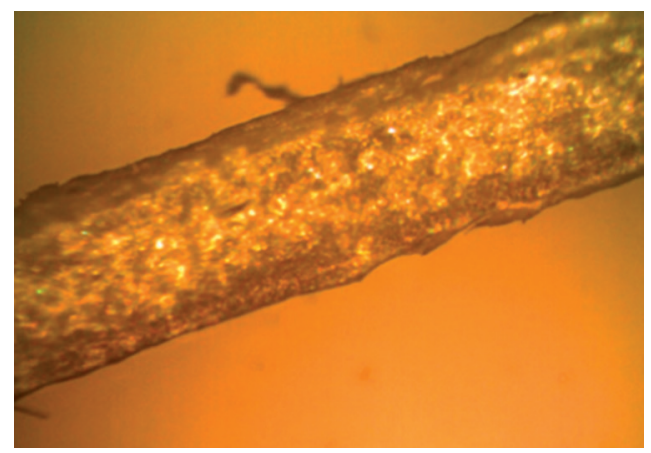

Figure 8.5: Multi-Layer Cup Wall

FSD, such as plates, bowls and cups, may be made from multiple co-extruded layers. This should be considered when using the FTIR instrument. Each layer should be studied separately. Firstly, it may be possible to see and measure the layers using microscopy, see Figures 8.4 and 8.5, and from FTIR analysis of microtome specimens. The FTIR should then be focused on to the individual layers. In the case of a PP plate with a $\mathrm{CaCO}_{3}$ filler, the carbonate is likely to be identified only in the middle layer in an A/B/A construction. The outer layer (A), the layer in contact with foodstuffs, must have food contact approval and would normally be made of a virgin polymer. 
Although a significant number of FSD are manufactured using plastics and their composites, there are many made from papers and boards. The approach to qualification and quantification of these disposables, in terms of data input to LCA, can involve a more visual based study.

Common carton board types that could be used in the FSD sector are:

1. Solid Bleached Board

2. Solid Unbleached Board

3. Folding Boxboard

4. White Lined Chipboard

5. Liquid Packaging Board

(Pro Carton, 2014).

The definition of board types is covered in DIN 19303. Although identification of these types of board is largely visual, use of microscopy and FTIR spectroscopy can help in sighting and identifying some carton and non-carton based layers. This is because a board can be built up from as many as eight layers with the middle layer potentially containing recycled material, kraft fibres or groundwood which is not visible with the naked eye. All five types of board are to be found in LCIA datasets (Ecoinvent v3.4, 2017).

The need to consider a percentage recycled content within these board types as a startof-life option within LCA, as would be the case with a plastic product study, may not be necessary as the individual board type LCIA data considers the typical recycled board content applied to specific board types such as White Lined Chipboard (chipboard production, white lined, RER, Author: Emilia Moreno Ruiz, Ecoinvent v3.4, 2017).

Suppliers of carton boards typically wish to show that the chain of custody of the material has been identified as responsible through the use of a Forest Stewardship Council (FSC) accreditation and its associated label. This stewardship approach influences the LCIA data (Straka, T. J., et al., 2010), hence attention should be paid to using data based on sustainably managed forests (Ecoinvent v3.4).

A popular FSD is the hot beverage paper cup, which is typically manufactured from a polymer coated liquid packaging board material (Ziada, H., 2009) formed so that the polymer coating appears on the inside of the cup. The nature of the polymer could be identified using FTIR. To identify the overall structure of the paper cup wall, the material thickness and $\mathrm{gsm}\left(\mathrm{g} / \mathrm{m}^{2}\right)$ could be measured. Due to the relatively small number of paper cup material suppliers and the relatively small number of material specifications, these measurements could confirm the board type to be used as input to the LCA. 
Having fully determined that the items being compared have the same functionality and performance as well as having established the composition of the materials from which the like functionality category products are manufactured, the resultant product economic inventory data could then be incorporated in to an LCA.

\subsection{Conversion Process Identification}

Conversion identification could be derived from the above-mentioned materials identification and a clear understanding of the conversion processes associated with the identified materials. It would appear necessary for the LCA operative to have packaging technology knowledge to make the correct conversion process and material process efficiency choices based on the identified component materials in order to reflect industrial reality adequately (Baitz, M., et al., 2012).

A thermoformed mono material PP cup is formed by single layer sheet extrusion followed by thermoforming. If the cup is produced from a compound containing a mineral filler and a white colour additive, the processes change. The mineral(s) and white (e.g. $\mathrm{TiO}_{2}$ ) additives are made into masterbatches; this involves high speed mixing/drying, twin screw compound extrusion and cutting/drying. The impacts of these processes are then applied to the masterbatches. The resultant compound will then be co-extruded into a middle layer in a multi-layer sheet which is then thermoformed. Had these components not been identified in the composite, their specific conversion processes would not have been accounted for in the product economic inventory.

Materials identification and their associated conversion processes identification could also indicate if any process waste is likely to have to be considered.

The geographic location of the conversion processes dictates their impact due to the use of local energy mixes and their specific environmental impacts. The issue of the value of the correct identification of the location of manufacture of an item is addressed in Chapter 9.

It is possible that, as regards the conversion process, an FSD manufacturer would be most likely to stipulate the application of their own specific conversion energy data. A manufacturer with a highly efficient plant, or one running on zero rated carbon green-electricity, will likely specify that their lower conversion environmental impact be reflected in their final product impact figures. In this study, it is assumed that the product stakeholders are absent.

As conversion is the major area in which specific data might replace generic data for some studies, it is important that the data type is expressed in the LCA study. Ideally, all the conversion processes within the same study should be either specific or generic, based on primary or secondary data. However, it is very unlikely that competitors would supply specific data for comparable products. 


\subsubsection{Generic Data versus Specific Data}

While the EU (Product Environmental Footprint (PEF) Guide, EU, Draft-2013, Annex) approach cited both generic or secondary data and specific or primary data, in the case of an FSD non-cooperative stakeholder study only generic data is available.

1. Generic data to be used due to the lack of specific data on competing products within a comparable LCA (Product Environmental Footprint (PEF) Guide, EU, Draft-2013, Annex), (Ingwersen, W.W., et al., 2012). Competitors could be unlikely to reveal their choices for the sake of another competitor's comparative LCA data quality.

2. With a significant percentage of the impact of an item derived from accurate raw materials identification (Grant, T., 2009) and with FSD manufacturers converting these raw materials, it could be that generic data for raw materials is most relevant. Raw materials come from varying sources and this may further justify the use of generic data.

3. If converter specific data was used, it would relate only to the conversion phase. In addition, some disposables manufacturers may have the latest and most efficient manufacturing processes. As this conversion phase can be a significant percentage (Grant, T., 2009) of the environmental impact of an item, specific data from highly efficient conversion processes would have an effect on the overall impact in a comparative study. Any comparative study involving specific conversion data would appear to have to seek specific conversion data for the other products in the comparison, or might have to express that one item has been calculated using specific conversion data while the others have not.

4. The type of LCA used in this study is an "accounting" type; this typically uses generic data (Baumann, H., et al., 2003).

Data relating to materials and processes must be technically relevant, be established in the same geographic area and time period, be complete $(90$ percent ideally: Product Environmental Footprint (PEF) Guide, EU, Draft-2013, Annex) and list uncertainties in the data. The methodology of the computations relating to the data should be appropriate and consistent. The data must be accessible.

It may also be important to consider that the datasets do not profess to be highly accurate, as this would be impossible. Typically, the "precision of a great deal of eco-data is low" (Ashby, M., 2009, p. 101). Some of the commonly available dataset sources are Bath University, Boustead, ELCD, Ecoinvent, Ademe, Carbon Trust, Vima, EIA, IVAM, Delft University, US EDF, MEEUP(EU), US EIA, BRE, BUWAL, Compass, Carbon Trust and Defra.

Single dataset sources are often limited in the material range they cover, making it necessary to source from various datasets within a single study. A final comparable dataset might likely show a spread of values for which an average could be used. 


\subsection{The Value of Component Identification as LCA Input}

Taking as an example the product in Table 8.2 above, in which the product is a $10 \mathrm{~g}$ plate. The plate is firstly studied based on its initial Current, or traditional, materials identification; this plate is the DemoV1 plate below. Then, using instrumentation, a detailed or more accurate material identification is carried out; this plate is the DemoV2 plate below.

1. DemoV1 plate Current Study

Material composition: $10 \mathrm{~g}$ PP

Production process: inline sheet extruded and thermoformed.

2. DemoV2 plate Detailed Study

Material composition: $5 \mathrm{~g} \mathrm{CaCO}_{3^{\prime}} 4.75 \mathrm{~g} \mathrm{PP}, 0.25 \mathrm{~g} \mathrm{TiO}_{2^{\prime}}$

Production process: drying, compounding and inline sheet co-extruded and thermoformed.

Both the DemoV1 and DemoV2 plates, being the same plate subject to different materials identification approaches, are assumed to be manufactured in a plant in Italy.

The DemoV1 plate is 56\% higher in ReCiPe endpoints total than the DemoV2 plate and the major life cycle stage impact percentages varies between both products, see Figure 8.6 below.

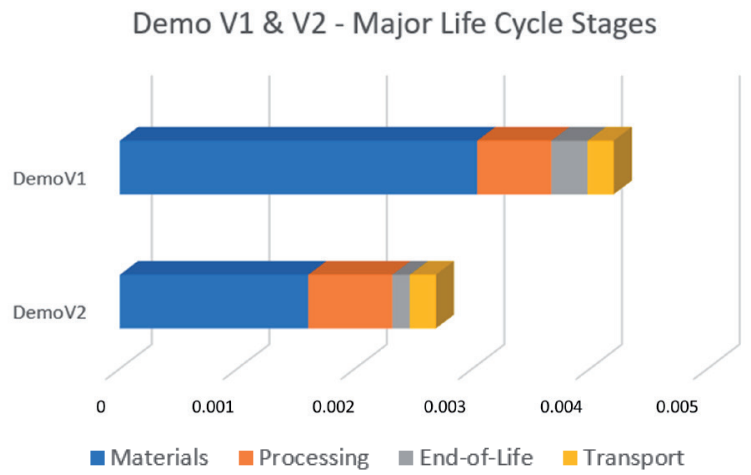

Figure 8.6: A DemoV1 and DemoV2 Plate ReCiPe Endpoints Total- Major Life Cycles Stages

It is interesting to note that the identification of $2.5 \% \mathrm{TiO}_{2}$ in the composition, as seen in Table 8.2 above, contributes to $6.03 \%$ of the ReCiPe endpoints total score when processing, transport and the end-of-life scenario are added to the product LCA study. Dependent on the scope of the study, this may still be considered a significant impact.

In order to gain a better understanding of the relative position of a plate, subject to the two approaches to identifying the material composition of this plate, DemoV1 and DemoV2 were individually added to the New Category of $22 \mathrm{~cm}$ diameter plates initially seen in 
Table 7.2 above. In Table 8.5 below, two New Category lists are shown, one with the DemoV1 added and the other with DemoV2 added. The Star Rating band widths were also set at $10 \%$ for this study, as they were for the plate study in Chapter 7.

Table 8.5: The Effect of Adding DemoV1 and DemoV2 Plates to the New Category

\begin{tabular}{|c|c|c|c|c|c|}
\hline \multicolumn{3}{|c|}{ New Category + DemoV1 } & \multicolumn{3}{|c|}{ New Category + DemoV2 } \\
\hline Ref. & Rank Order & Star Rating & Ref. & Rank Order & Star Rating \\
\hline Plate-1 & 1 & 4.5 & Plate-1 & 2 & 4.5 \\
\hline Plate-2 & 16 & 2 & Plate-2 & 16 & 2 \\
\hline Plate-3 & 17 & 2 & Plate-3 & 17 & 2 \\
\hline Plate-4 & 5 & 4 & Plate-4 & 5 & 3.5 \\
\hline Plate-5 & 14 & 2 & Plate-5 & 14 & 2 \\
\hline Plate-6 & 15 & 2 & Plate-6 & 15 & 2 \\
\hline Plate-7 & 6 & 3 & Plate-7 & 6 & 3 \\
\hline Plate-8 & 8 & 2.5 & Plate-8 & 8 & 2.5 \\
\hline Plate-9 & 2 & 4 & Plate-9 & 3 & 4 \\
\hline Plate-10 & - & - & Plate-10 & - & - \\
\hline Plate-11 & - & - & Plate-11 & - & - \\
\hline Plate-12 & 9 & 2.5 & Plate-12 & 9 & 2.5 \\
\hline Plate-13 & 19 & 0 & Plate-13 & 19 & 0 \\
\hline Plate-14 & 20 & 0 & Plate-14 & 20 & 0 \\
\hline Plate-15 & 4 & 4 & Plate-15 & 4 & 4 \\
\hline Plate-16 & 11 & 2.5 & Plate-16 & 11 & 2.5 \\
\hline Plate-17 & - & - & Plate-17 & - & - \\
\hline Plate-18 & 12 & 2.5 & Plate-18 & 12 & 2.5 \\
\hline Plate-19 & 13 & 2.5 & Plate-19 & 13 & 2.5 \\
\hline Plate-20 & 7 & 3 & Plate-20 & 7 & 3 \\
\hline Plate-21 & 18 & 1.5 & Plate-21 & 18 & 1.5 \\
\hline Plate-22 & 10 & 2.5 & Plate-22 & 10 & 2.5 \\
\hline Plate-23 & - & - & Plate-23 & - & - \\
\hline DemoV1 & 3 & 4 & DemoV2 & 1 & 5 \\
\hline
\end{tabular}

The yellow cells in Table 8.5 above indicate changes in the Rank Order number and the blue cells indicate changes in the Star Rating due to the change in approach taken to identify the material composition of the demonstration plate. 
Taking a Detailed study of the material composition of the plate, as seen in DemoV2, places the demonstration plate in Rank Order position 1, compared to the Current more visual study of the plate which would place it at Rank Order position 3. The Star Rating would also change to 5 Stars in the case of DemoV2 from 4 Stars in the case of DemoV1 due to the Mean ReCiPe endpoints total score of the category.

The difference in the relative position of the Demo plate in a comparative ECS can then be seen, based on the two materials identification approaches. The results show a change in the plate of the highest ranking and rating in the category; the implications of this change could be questioned as the results of the study could be corrupted by the lack of a Detailed approach to material identification.

A single operator could possibly identify the detailed material composition of the demonstration plate, as per DemoV2, within 30 minutes using analytical instrumentation and the appropriate technologically relevant knowledge. It could be questioned if this could be achieved, with any level of accuracy, in the same time using any of the methods described in Chapter 5.

\subsection{Level of Resolution in Component Identification for LCA Input}

The degree to which a product is analysed could also be questioned. It could be questioned whether this should be based on a percentage weight of the component in the product (Vogtlander, J.G., 2010) or a percentage impact derived from the identified component. This should be defined in the scoping stage of the study. The study scope describes the system to be studied, the quantity of information to be collected and the associated level of detail and quality (Weitz, K., et al., 1999).

Taking the materials in Table 8.2, the instrumentation analysis approach led to a reduction in the ReCiPe endpoints total of $46.79 \%$ over a non-instrument based analysis approach. Of the final, materials only, analysed product, the component contribution in weight terms of the $\mathrm{TiO}_{2}$ was $2.5 \%$ but in ReCiPe endpoint terms it was $10.55 \%$. The much higher weight $\mathrm{CaCO}_{3}$ contributed $50 \%$ of the weight but only $0.18 \%$ of the ReCiPe endpoints total, as can be seen in Table 8.6 below.

Table 8.6: A Product \% Material Component Weight versus \% Material ReCiPe Endpoints Total

By Weight \% By Material ReCiPe \%

\begin{tabular}{l|c|c}
\hline $\mathbf{P P}$ & 47.50 & 89.26 \\
\hline $\mathbf{C a C O}_{\mathbf{3}}$ & 50.00 & 0.18 \\
\hline $\mathrm{TiO}_{\mathbf{2}}$ & 2.50 & 10.55 \\
\hline
\end{tabular}


This would suggest the need to set an impact category based minimum level within the rule used to define material component identification. Vogtlander, J.G., 2010 refers to a "common rule" in which "something might be neglected when the effect on the total LCA is less than $2 \% "$ (p. 13). However, while a component could have a generally low score for one impact category, such as GWP, it may make a far higher contribution to another impact category. In this case, it would be necessary to understand the goal of the study and the relevance of one impact category compared to another as regards the objectives of the goal. The contribution that this impact category makes to any weighting system may also need to be understood. In the case of this study, only ReCiPe endpoint total values are used.

In Vogtlander, J.G., 2010 the consideration of potentially neglecting a component or activity when the effect on the total LCA is less than $2 \%$ may not constitute a useful rule. In the above case, $50 \%$ of the product by weight is $\mathrm{CaCO}_{3}$ while it constitutes only $0.18 \%$ of the ReCiPe endpoints total. Hence, the effect of the inclusion of this component in the product has a significant impact reduction effect on the final product.

Excluding a low by weight, or low by impact, material component could lead to the exclusion of the related processing activity which may itself contribute a high impact to the product life cycle.

Using analytical instrumentation and the appropriate technologically relevant knowledge as described above may be an efficient way of establishing the level of resolution required for the LCA study during the scoping process.

\subsection{Chapter 8 Conclusions}

In a non-cooperative stakeholder study to establish a comparative ECS, it would seem evident that product economic inventory material component identification would be required. This is required to provide the correct material components qualitative and quantitative input to the LCA used to formulate the comparative ECS. Materials analysis also aids in conversion process identification and has implications for the accounting of transport and end-of-life scenarios.

Research shows the importance of carrying out as full an analysis as possible. The different impacts of the $\mathrm{CaCO}_{3}$ and $\mathrm{TiO}_{2}$ fillers is significant, leaving little justification for ignoring either. When there is a difference in outcome, the only justifiable stance is to apply the most thorough analysis available. A less thorough approach could be discredited.

Alternative methods for materials analysis could be seen to be vital in an LCA study, as materials data is often either not available or is from sources who cannot be relied upon. 
It is evident that taking a simply visual or traditional approach to materials identification may overlook vital materials and processes in the product life cycle.

This Current visual or traditional approach, confirmed in the questionnaire in Chapter 5 as common practice, can lead to the incorrect product economic inventory data input to an LCA study, resulting in the potential incorrect positioning of a product within a comparative ECS. However, the benefits of knowing the exact material composition may be less significant if the other products within the comparative study force a degree of bunching, but this would not be known in advance. If the products were simply to be Rank Ordered, the issue of bunching would not be relevant. This would again indicate the need for a very accurate category definition or FU.

Research shows that laboratory analytical instrument based materials analysis contributes to increasing the potential accuracy of a comparative ECS. It also shows that this type of analysis is time efficient, although the necessary instruments would be required at an initial cost to the operator.

A time efficient instrument based approach may aid in identifying the scope of the LCA study counter to the cited recommended approach that inventory is collected after scoping. Due to the existing time and cost expense of the traditional inventory collection methods described in Chapter 5.

While this study considers the material composition effect on a comparative ECS, some of the same issues would exist for other uses of LCA, such as in the eco-innovation of a product against a comparative product LCA of questionable product economic inventory input.

Chapter 7 considered the impact on comparative ECS of PFR and FU choice. This chapter then considered the impact based on material component identification. Chapter 9 will look at a further potential concern in developing a comparative ECS in the form of country of origin identification. 


\section{Chapter 9}

\section{Country of Origin (CoO) Identification for LCA Input}


This chapter seeks to identify an approach to aid in establishing the country of origin (CoO) of the manufacture of a product, given the potentially significant contribution that manufacturing energy can make to the overall impact of the product and hence on the relative position of products within a comparative ECS.

Addressing Stage 2 (Studying the factors to be addressed in developing a method) and specifically research question $2 \mathrm{c}$ :

RQ 2c. How should issues, related to the country of origin identification of products or materials, be taken into account, noting that in some cases such details might be uncertain?

\subsection{Introduction}

The types of electricity generation in a region constitute one of the main sources of regional greenhouse gas intensity (Peters, G. P., et al., 2006). Electricity usage and its emissions are important contributors to the life cycle impacts of many products (Weber, C. L., et al., 2010) such as FSD.

In a comparative ECS study of FSD, a product category for comparison would need to be established and the material contents of the individual products identified. Subsequently the product $\mathrm{CoO}$ would need to be identified as input to an LCA used to establish the comparative ECS.

The country of manufacture of a specific FSD product may not always be known. The lack of this $\mathrm{CoO}$ information may lead to uncertainty as to the final relative position of products due to the incorrect choices made at the following life cycle stages:

1. raw material generic data

2. conversion process energy

3. transport distance and type.

In this chapter the effect of the unknown $\mathrm{CoO}$ on each of the above life cycle stages will be considered, as well as the cumulative effect across all the stages.

This chapter will research the extent to which the $\mathrm{CoO}$ of an FSD product is likely to be unknown and how this lack of knowledge of the $\mathrm{CoO}$ of the FSD could be addressed with regard to LCA input. To research to what extent this lack of knowledge of $\mathrm{CoO}$, and any proposed solution to addressing this lack of knowledge, influences the relative position of a product within a comparative ECS. 


\subsection{To What Extent is the CoO Likely to be Unknown with regard to FSD}

In the USA, CoO must be displayed on product labels (Smoot-Hawley TariffAct, 1930) which would simplify the process of $\mathrm{CoO}$ identification for a comparative impact study based on a category derived from the US market. The $\mathrm{CoO}$ marking remains non-compulsory inside the European Union for most manufactured goods. However, a compulsory CoO marking for products has been regularly discussed during the past decade between the European Parliament and the Commission, and a new regulation might appear in the future.

Regulation (EU) No 1169/2011 on the provision of food information to consumers, obliges the identification of $\mathrm{CoO}$ for some products, such as origin labelling for meat from pig, sheep, goat and poultry. However, the identification of $\mathrm{CoO}$ of the packaging or any associated FSD packed with the meat is not obligatory.

Barcode prefixes are not a reliable method of $\mathrm{CoO}$ identification as they can simply identify the country where the importer is located and not necessarily where the product was manufactured.

Retailer and wholesaler product sources change, which could make it difficult to identify the $\mathrm{CoO}$ of the FSD product on the date of any study. As described in Chapter 2, the routes to market could also vary and could be:

1. Manufacturer sells own branded product.

2. Importer sells product under own brand.

3. Retailer sells product under own brand.

4. Manufacturer sells product under retail own brand.

5. Importer sells product under retail own brand.

6. Manufacturer sells to manufacturer to expand their range and sell under own brand.

7. Manufacturer sells to manufacturer to expand their range and sell under importer's own brand.

8. Manufacturer sells to manufacturer to expand their range and sell under retailer's own brand.

The above list of FSD flows are diagrammatically demonstrated below in Figure 9.1; the numbers within Figure 9.1 correspond to the above flows. This is not an exhaustive list of all the permutations of FSD supply chains. It could be that far more elaborate FSD supply chains exist in the food service sector compared to the retail sector. 


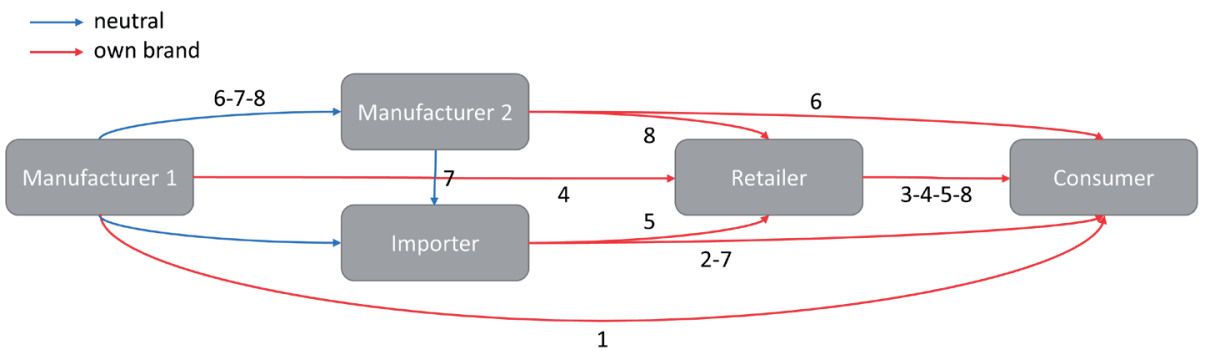

Figure 9.1: Various Routes to Market of FSD

In developing a stakeholder non-cooperative based comparative ECS, it is possible that not all $\mathrm{CoO}$ of the comparative products could be known to a claim maker. Such a product may be made up of separate products, such as a cup and a lid, which tend to get sourced separately.

\subsection{The Effect of the Lack of CoO Knowledge}

In this subchapter, the effects of generic data choice due to the lack of knowledge of $\mathrm{CoO}$ will be studied as relates to the life cycle stage implications and the cumulative implication. The study will use ReCiPe endpoints total to establish Rank Order number and the Star Rating, with a bandwidth of $10 \%$, as described in Chapter 6 .

In Table 9.1 below, two tables are shown, each showing the same $22 \mathrm{~cm}$ diameter plate New Category as described in Chapter 7. The last plate in each table has the same weight of the same materials, using the same conversion process energy demand and the same end-of-life scenario. However, one is manufactured in France (Demo Fr.) and transported $450 \mathrm{~km}$ by truck, the other is manufactured in China (Demo Cn.) and shipped $20000 \mathrm{~km}$ by container ship. This involves two different raw material source regions, two different national energy impacts and the associated transport distances and types. 
Table 9.1: The Same 22cm Plate Sourced from France and China

\begin{tabular}{|c|c|c|c|c|c|}
\hline \multicolumn{3}{|c|}{ New Category + Demo Fr. } & \multicolumn{3}{|c|}{ New Category + Demo Cn. } \\
\hline Ref. & Rank Order & Star Rating & Ref. & Rank Order & Star Rating \\
\hline Plate-1 & 2 & 4.5 & Plate-1 & 1 & 4.5 \\
\hline Plate-2 & 16 & 2 & Plate-2 & 16 & 2 \\
\hline Plate-3 & 17 & 2 & Plate-3 & 17 & 2 \\
\hline Plate-4 & 5 & 4 & Plate-4 & 4 & 4 \\
\hline Plate-5 & 14 & 2 & Plate-5 & 14 & 2 \\
\hline Plate-6 & 15 & 2 & Plate-6 & 15 & 2 \\
\hline Plate-7 & 6 & 3 & Plate-7 & 6 & 3 \\
\hline Plate-8 & 8 & 2.5 & Plate-8 & 8 & 2.5 \\
\hline Plate-9 & 3 & 4 & Plate-9 & 2 & 4 \\
\hline Plate-10 & & & Plate-10 & & \\
\hline Plate-11 & & & Plate-11 & & \\
\hline Plate-12 & 9 & 2.5 & Plate-12 & 9 & 2.5 \\
\hline Plate-13 & 19 & 0 & Plate-13 & 19 & 0 \\
\hline Plate-14 & 20 & 0 & Plate-14 & 20 & 0 \\
\hline Plate-15 & 4 & 4 & Plate-15 & 3 & 4 \\
\hline Plate-16 & 11 & 2.5 & Plate-16 & 11 & 2.5 \\
\hline Plate-17 & & & Plate-17 & & \\
\hline Plate-18 & 12 & 2.5 & Plate-18 & 12 & 2.5 \\
\hline Plate-19 & 13 & 2.5 & Plate-19 & 13 & 2.5 \\
\hline Plate-20 & 7 & 3 & Plate-20 & 7 & 3 \\
\hline Plate-21 & 18 & 1.5 & Plate-21 & 18 & 1.5 \\
\hline Plate-22 & 10 & 2.5 & Plate-22 & 10 & 2.5 \\
\hline Plate-23 & & & Plate-23 & & \\
\hline Demo Fr. & 1 & 4.5 & Demo Cn. & 5 & 3.5 \\
\hline
\end{tabular}

In Table 9.1 above, it is evident that CoO choices can have an effect on the resultant environmental impact of a product and their position within a comparative ECS. The cells marked in yellow above are those plates whose Rank Order number has changed and the blue cell represents the plate whose Star Rating has changed. The influence of life cycle impact stages as relates to this change are addressed in the following subchapters. 


\subsubsection{Lack of CoO Knowledge regarding Raw Material Generic Data Choices}

In the case of a product of unknown $\mathrm{CoO}$ being studied, the associated raw material source is unknown. When generic, or secondary, data from Ecoinvent (Ecoinvent v3.4) is used for materials, four raw material geographic source options may exist; these are:

1. $\mathrm{GLO}=$ Global - represents activities which are considered to be an average valid for all countries in the world. "Market for" data is that to be used when the source is unknown (Ecoinvent v3).

2. RER = Europe - represents Europe.

3. ROW $=$ Rest of World - is the difference between the GLO minus all the smaller regions available for the given activity.

4. $\mathrm{CH}, \mathrm{CZ}, \mathrm{CN}$, etc $=$ country specific data.

Table 9.2: Materials Impact Data Origin Options in Ecoinvent

\begin{tabular}{c|l|l}
\hline market for polypropylene, granulate & polypropylene, granulate $[\mathrm{kg}]$ & GLO \\
\hline polypropylene production, granulate & polypropylene, granulate $[\mathrm{kg}]$ & RER \\
\hline polypropylene production, granulate & polypropylene, granulate $[\mathrm{kg}]$ & $\mathrm{ROW}$ \\
\hline
\end{tabular}

In the plate study above, the raw material in the French and Chinese plates was Polypropylene (PP). In Table 9.3 below, the relative ReCiPe endpoint total value of the PP material per geographic region can be seen as displayed by Ecoinvent v3.4 (extract from Ecoinvent v3.4 database datasets listed in Table 9.2 above).

Table 9.3: The Relative Value Differences between Ecoinvent Geographic Regions

\begin{tabular}{c|c}
\hline \multicolumn{2}{c}{ 1kg Polypropylene } \\
\hline \multicolumn{2}{c}{ ReCiPe Endpoints - Total } \\
\hline GLO & 0.31303 \\
\hline RER & 0.30378 \\
\hline ROW & 0.30382 \\
\hline
\end{tabular}

In the case of the French and Chinese PP plates, the difference in ReCiPe endpoints total by Ecoinvent geographic region would be very small between RER and ROW. The difference between knowing the source to be European and using the RER figure or having no knowledge of the source, in which case the "market for" GLO figure is adopted, is 2.96\%.

As was cited in Chapter 8, there is significant benefit in identifying the material composition of a product to compile the product inventory LCA input in the preparation of a comparative ECS. Based on generic LCIA geographical impact data for PP, it could be said that identifying the source of these materials is of more limited value in terms of accounting purely for the material impact, although this may depend on the material type. 
Processes required to formulate carton materials may display significantly greater variance between RER and ROW, such as in the case of folding box board production in which the figures differ by 20.5\% (Ecoinvent v3.4, folding box board production, ReCiPe endpoints $\mathrm{H}$ total).

Identifying the $\mathrm{CoO}$ of a product for other more quantitatively significant life cycle stages would also benefit the choice for LCIA geographical impact data to be used for the identified materials.

\subsubsection{Lack of CoO Knowledge regarding Conversion Process Generic Data Energy Choices}

In Chapter 8, it was cited that identification of the material composition of a product can act to indicate the conversion processes used to manufacture the product. Technologically relevant knowledge regarding FSDs will also help regarding conversion process technology types; this will be addressed in Chapter 10.

In this subchapter, fixed conversion processes are chosen and the effect of national energy impacts are researched based on these conversion processes.

It can be seen in the chart below, Figure 9.2, that the move from production in France to China has a significant effect in the percentage value of each life cycle stage. This is particularly evident in the product conversion stage.

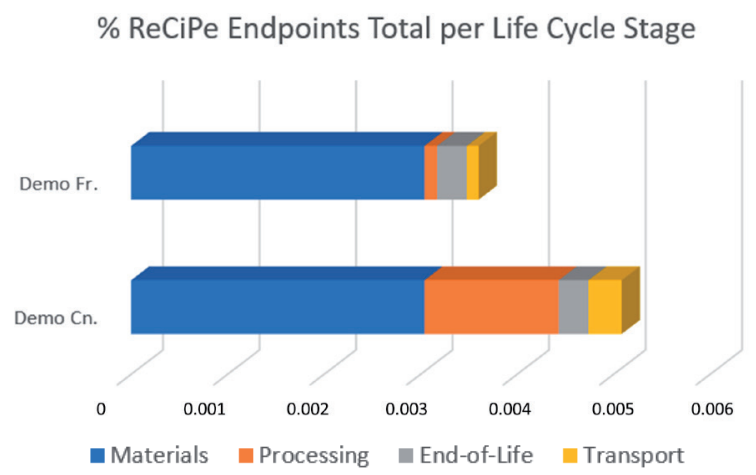

Figure 9.2: Percentage ReCiPe Endpoints Total Contribution to the Life Cycle of the French and Chinese Plate

In the example above, the conversion processes involve extrusion and thermoforming, and the chosen energy source for production is electricity. The processing power required is the same for both the French and Chinese conversion processes.

The ReCiPe endpoints total data for French electricity (Ecoinvent v3.4, electricity medium voltage) is $6.43 \%$ of the Chinese equivalent figure. To average out global electricity figures, or to simply remove processing if it is of the same type in comparable products, could risk significant distortion of the relative position of products from efficient and inefficient electricity impact countries. 
The manufacturing of FSD involves numerous electricity consuming conversion processes. The large variances in electricity impact cited above could have significant effect on the relative position of one item versus another. Hence it would seem of importance to identify the $\mathrm{CoO}$ in the development of a comparative ECS.

\subsubsection{Lack of CoO Knowledge regarding Transport Distance and Type Data Choices}

Identification of the $\mathrm{CoO}$ helps to establish the likely distances and transport types used to deliver the FSD to the source. In the above plate example, the density of the packed plates per $\mathrm{m}^{3}$ is such that the transport is based on weight (Vogtlander, J.G., 2010).

In Figure 9.2 above, the percentage of all the transports can be seen to be small, with the transports related to the French plate being 3.33\% of the total French plate impact and $6.74 \%$ of the total Chinese plate impact. Based on the density of typical FSD and their high quantity per movement due to their small size, it could be said that transport is not a significant contributing factor, although this depends on the chosen scope of the study. Were impacts of this percentage value to be required in the study scope, then, in the case of these two plates, the difference in impact due to transport is significant. The identification of $\mathrm{CoO}$ makes an important contribution in establishing transport impact values.

Where transport may become of greater concern is when a very low density product is shipped a significant distance by truck. The opportunity of this life cycle stage to go unidentified is likely to be low since the product density could be identified at the material study phase and the transport type and distance at the $\mathrm{CoO}$ study phase.

\subsubsection{Lack of CoO Knowledge - Conclusion}

The lack of knowledge of the CoO of products in a comparative ECS could be said to have significant effect on the relative position of products in the comparative assessment. While the effect of the transport and materials generic data choice could be relatively small, it is the $\mathrm{CoO}$ of the conversion processes that have the more significant influence.

It would appear of importance to identify the $\mathrm{CoO}$ of a product in a comparative claim.

A solution to the lack of knowledge of the $\mathrm{CoO}$ of an item may be to leave it out of the study or use a single global figure. This approach would have to be considered for the potential distortion this creates. In a high processing energy category of high resolution, the effects of this approach may have to be considered. However, in a low processing energy category, in which most of the embodied impact is in the materials, within a low resolution category, it might be more acceptable to use supernational energy figures such as GLO.

The choice as to how to address an item for which no $\mathrm{CoO}$ knowledge is available may be dependent on the impact mix of the category product across its life cycle stages. 


\subsection{Proposed Solutions to the Issue of a Lack of Knowledge as to the Country of Origin of a Product}

In any final category of products, there risks being those products for which the $\mathrm{CoO}$ is not visually evident, based on either:

1. no indication on the label

2. unknown source of the branded or own-label supplier's goods

3. unrecognizable embossing, shape, tool deformity or design specific to sources

This visual approach is dependent on product and market knowledge. Thereafter, knowledge derived from a Detailed approach could be considered. The term Current and Detailed are used in the same context as they were used in Chapter 6. Current being a visual, or traditional, assessment of a product and Detailed being a laboratory analysis assessment of the product.

In Figure 9.3 below, an approach is proposed which is further studied in the subchapters:

\subsubsection{Expert Knowledge Based \\ 9.4.2 Detailed FTIR/XRF Based \\ 9.4.3 Detailed IRMS Based}

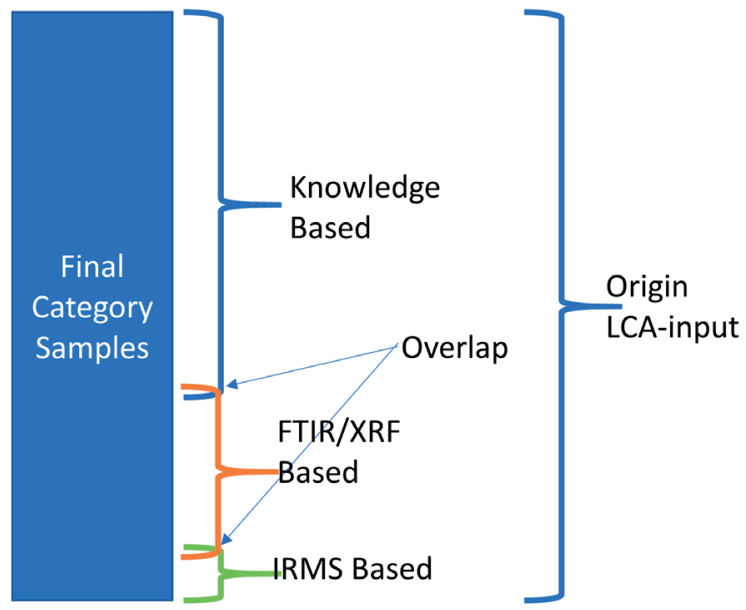

Figure 9.3: Proposed Approach to Origin Definition

Figure 9.3 above proposes an order of approach to $\mathrm{CoO}$ identification. The overlaps relate to the point where the results of the previous approach may further confirm those of the next approach, with the FTIR/XRF approach potentially confirming the Expert Knowledge based result and the IRMS further potentially confirming the FTIR/XRF approach. 
Identifying methods to establish the $\mathrm{CoO}$ of an FSD is a significant study. Suggestions within this subchapter are not exhaustive and many other approaches may be viable. The objective of this subchapter is to indicate that $\mathrm{CoO}$ identification methods may exist and could be of value in improving the viability of a comparative ECS for FSD.

\subsubsection{Expert Knowledge Based Simple Approach}

An expert is defined as "somebody who obtains results that are vastly superior to those obtained by the majority of the population" (Gobet, F., 2015). They are further defined as having knowledge based on their experience and occupation. Purchasers whose careers have been spent working with FSD may be said to be experts.

Examples of the types of visual indicators that may cause an expert to identify the origin of an FSD item could be:

1. manufacturer's logo on the item

2. unique shape or design of the item; weight or thickness; gloss or matt surface; elasticity and strength

3. repeated deformities in the item, for instance tool wear or damage

4. unique material types, for example a specific source supplier of PP cutlery where all others supply PS

5. specific logos/markings on the item, for example the distinctive Taiwanese recycling symbol

6. identification of the retailer and hence prior knowledge of their source (market based knowledge)

7. packing types, for example a bag instead of a flow wrap, specific closure types

8. packaging material choices, for instance HDPE sleeves for cup stacks versus LDPE

9. packaging print wordings, fonts and types

Such experts could possibly make a major contribution to the definition of the origin of a series of FSD. This hypothesis was tested in 2013 involving the identification of domestic garbage bags sold in retail. Three senior purchasers from the companies Depa, Van Der Windt and Paardekooper, with speciality related to garbage bags, were interviewed separately. The origin of more than three quarters of the bags in each category of garbage bags were defined based on a consensus across all three purchasers (see Appendix H). The same study was made for disposable hot beverage paper cups involving TVD Disposables, Depa, Halma Packaging, Paardekooper and Van der Windt producing similar results (Appendix I).

It could be reasonably said that an expert, taking a visual approach, could aid in establishing the origin of a series of FSD. Their knowledge may make a further contribution to the Detailed based approach. They may also be able to define what can be discounted in terms of what countries can be left out of any product study. 


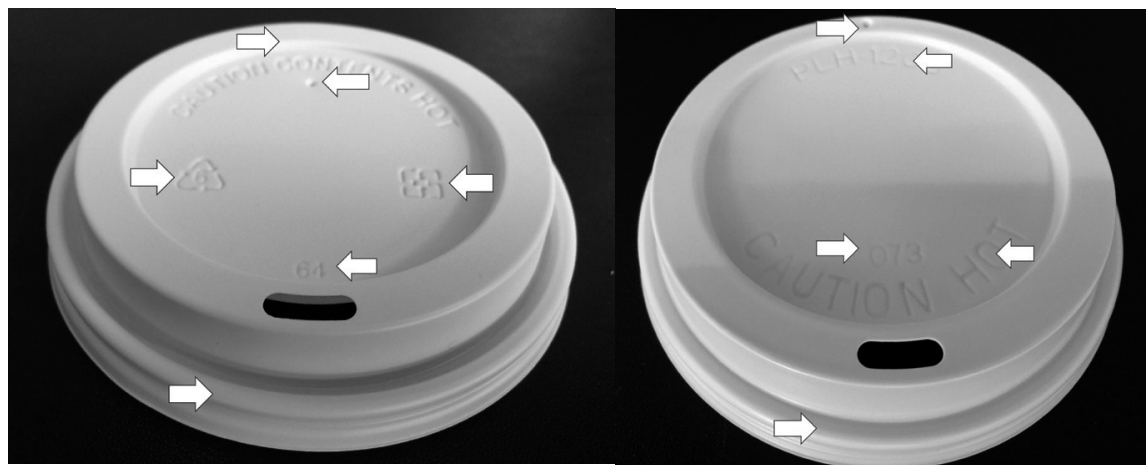

Figure 9.4: Examples of Identifiable Differences between Two Paper Cup Lids

As an example of identifiable differences between two like functionality FSD items, two 16 oz paper cup standard design lids are shown in Figure 9.4 above. The lids are from different suppliers, the lid on the left is from supplier $A$ and the one on the right from supplier $B$.

\section{Supplier A}

1. The warning on this lid reads CAUTION CONTENTS HOT in a specific font type and font size. The location of the warning is opposite the sip hole.

2. The vent hole is on the flat part of the lid under the warning statement and is pushed in.

3. Left of the centre of the lid shows the PS recycling mobius symbol as is common in Europe.

4. Right of the centre of the lid shows the Taiwanese recycling symbol common to China and Taiwan.

5. Above the sip hole is the tool cavity number.

6. The outer edge and skirt of the outer part of the lid is of a specific design.

\section{Supplier B}

1. The warning on this lid reads CAUTION HOT in a specific font type and font size. The location of the warning is next to the sip hole.

2. The vent hole is on the risen surface and is punched out rather than pushed in.

3. The lid has a product reference number.

4. The tool cavity number starts with a " $\mathrm{O}$ " and is placed above the warning.

5. The outer edge and skirt of the outer part of the lid is of a specific design.

These visible differences in layout and design of standard items are of the type that may aid the expert in identifying the source or $\mathrm{CoO}$. In this case, both lids were identified as being from China, with lid A being from a Shanghai manufacturer and lid $B$ being from a Nanjing manufacturer. 


\subsubsection{FTIR/XRF Based Detailed Approach}

As noted in Chapter 8, FTIR, XRF and other instrumentation is used in the identification of the composition of a product. A cited composition could be identifiable against a library of comparative item compositions. This could aid in identifying a specific manufacturer of a product.

Techniques such as XRF have often been used in criminal examinations of different kinds of trace evidences (Zieba-Palus, J., et al., 2008) and FTIR to identify origin (Dirwono, W., et al., 2010).

"Normally, the forensic scientist is requested to compare the tape retrieved from the crime scene with tape found with a suspect. At the NFI (Netherlands Forensic Institute) a combination of visual investigation (physical fit, tape dimensions, colour, morphology), FT-IR and XRF is used routinely to compare tapes. FT-IR can be used to identify the type of glue and backing polymer. A combination of visual comparison and XRF analysis generally suffices to discriminate between different tape products but cannot be used for further discrimination between different batches of one brand of tape product." (Wakelin, D., et al., 2008).

Figure 9.5: Identifying the Origin of Packaging Tape

This may require the claim maker to manage a comprehensive and updated library of all available samples of like functionality products, incorporating results from studies using, for example:
1. FTIR
2. $\mathrm{XRF}$
3. microscopy
4. density
5. weight
6. size

An FSD item taken from a retail or Food Service source will typically consist of the following, possibly distinctive, component parts:

\section{The FSD item itself:}

1. the primary material within the FSD item

2. additions to the primary material, such as various groups of additives, stabilizers, compounding ingredients, pigments, recycled content qualities and fillers

3. additional materials added to, coated or extruded on to the primary material

4. multiple layer configuration, involving layer location and relative thickness 


\section{The packaging of the FSD item:}

1. plastic bag or flow wrap film of various film types

2. ink printed on the plastic film or on to a separate label

3. label adhesive types

4. label stock material

5. in some cases, tapes and other closure materials

The number of detailed evident variables across the above product ingredients could be considered to be sizable. This may be enough to establish a unique footprint for the product which can then be used for comparison purposes.

It should be noted that many materials are not homogenous and that at any time a manufacturer could change their composition.

Comparisons with this library could also aid in confirming or denying a knowledge based estimation of a source, referred to as the overlaps in Figure 9.3 above.

\subsubsection{Isotope Ratio Mass Spectrometry based Detailed Approach}

Isotope ratio mass spectrometry (IRMS) has been used in authentication and more recently in forensic science in a source inference perspective (Gentile, N., et al., 2015). "Authenticity of a material - and thus its source - may be defined by its geographical provenance (regional or continental) or its specific signature derived from features of production (manufacturer, batch, raw materials, production method, etc.)." (p. 140).

It is possible to identify the region of origin of products from the isotope analysis of their components.

It is not possible to determine region of origin by analysing a single sample when there is no background population data available for comparison. However, by using a database of known origin components, which ideally covers the expected range of possible origins, it is possible to make sample-to-sample comparisons and determine the relative likelihood that a component came from a particular source (http://ecophys.utah.edu, cited 10/01/2016).

As cited above in Chapter 9.4.2, an FSD product offering can be composed of multiple components and ingredients, all of which could display a unique footprint.

Confirmation of origin authentication of materials, typical to those found in FSD and their packaging, is addressed in the following scientific papers: 


\section{Paper}

Jones, K., Benson, S., \& Roux, C. (2013)

Benson, S. J. (2012)

\section{Ink}

Chesson, L. A., Tipple, B. J., Barnette, J. E., Cerling, T. E., \& Ehleringer, J. R. (2015)

\section{Plastic}

Taylor, E., Carter, J. F., Hill, J. C., Morton, C., Daeid, N. N., \& Sleeman, R. (2008)

Idoine, F. A., Carter, J. F., \& Sleeman, R. (2005)

Causin, V. (2010)

Causin, V. (2015)

Benson, S. J. (2012)

\section{Tapes}

Carter, J. F., Grundy, P. L., Hill, J. C., Ronan, N. C., Titterton, E. L., \& Sleeman, R. (2004)

Horacek, M., Min, J. S., Heo, S., Park, J., \& Papesch, W. (2008)

It should be noted that much of the instrumentation described above cannot just be purchased and immediately used; experts with materials analytical knowledge are needed to use and interpret their results. 


\subsubsection{The Overlap between both Spectrometry Approaches and the Expert Knowledge Approach}

In Figure 9.3 above, it is assumed that the various approaches may potentially confirm one another's result, this being referred to as "overlap" in the diagram. Questions could be asked as to whether this would always be the case: will they always confirm one another's results? What are the situations in which a knowledgeable expert is confronted with a high spectroscopic match that conflicts with their results?

In such a case, it might be wise to source both the questioned products from their manufacturer so that their spectra can again be logged in the library for further comparison with the product under study. Rules as to how to address this potential issue would have to be established.

\subsection{Chapter 9 Conclusions}

It is noted that the $\mathrm{CoO}$ of an FSD may be unknown and this lack of knowledge of the CoO can have consequences for the relative position of an item within a comparative ECS. This lack of $\mathrm{CoO}$ knowledge for some products in a category, when the $\mathrm{CoO}$ of other products is known, could result in complication regarding the development of a comparative ECS.

This might be resolved by removing the manufacturing phase or using global energy data rather than country specific data. It could be seen that these options will distort the relative position of products within a comparative ECS. The importance of this distortion may vary depending on the configuration of the category leading to situations in which any exclusions or generalizations may lead to more or less representative results.

In the above examples, plates from France and China were studied, because:

1. both countries supply plates into the Dutch retail market

2. both countries have very different electricity environmental footprints

3. both countries are far apart involving different transport types and distances

It could be said that choosing France and China in this example is extreme; however, within the FSD market it is possible that the claim maker could be faced with needing to know if the plate is French or Chinese. This is an example of why it may be important to identify $\mathrm{CoO}$ in any comparative ECS study.

With regard to research question 2c "How should issues, related to the country of origin identification of products or materials, be taken into account, noting that in some cases such details might be uncertain?", a variety of potential approaches to identifying the $\mathrm{CoO}$ have been researched. These are not exhaustive but are examples of techniques that may potentially aid in identifying the $\mathrm{CoO}$ of an FSD. It can be seen that this would be a significant study in its own right. 
Both expert knowledge from experienced FSD purchasers and a Detailed level study of the component parts within an FSD against an appropriate library, may help to reduce uncertainty with regard to identifying the $\mathrm{CoO}$ of a product as regards LCA input for a comparative ECS study.

Chapter 10 will address RQ 2d ("What are the further consideration identified in developing the method?") based on observations from research within Chapters 7, 8 and 9. 


\section{Chapter 10}

\section{The Role of Relevant Product and Technology Knowledge and Issues of its Interpretation}




\subsection{Introduction}

This chapter then addresses research question $2 \mathrm{~d}$.

RQ 2d. Do any further considerations need to be included in developing the method?

The previous chapters have laid out the sequence of analyses required to complete an LCA exercise and the product economic inventory data needed as input to the LCA. However, this is a suitable point at which to review an important issue that recurs at all of the earlier stages. Ensuring the validity of the data used is clearly important, and this is often quite challenging to achieve. In this chapter, the need for relevant product and technology knowledge is reviewed, as this is often crucial to ensure the accuracy of outcomes.

Based on the observations described in earlier chapters and further developed and presented in Chapters 7, 8 and 9, the following product economic inventory LCA input stages need to be taken into account:

1. Functional Unit Stage - the category definition and functional unit definition.

2. Material Composition Stage - in which the component qualitative and quantitative data is defined.

3. Origin Stage - in which the $\mathrm{CoO}$ is defined.

The approach described in Chapters 7, 8 and 9 with regard to the LCA input will further be referred to as FUMCO in the text. FUMCO will now replace the term Detailed previously used in this study text.

In Figure 10.1 below, the three stages are shown as part of the route between the product type choice primary category and the final LCA input. 


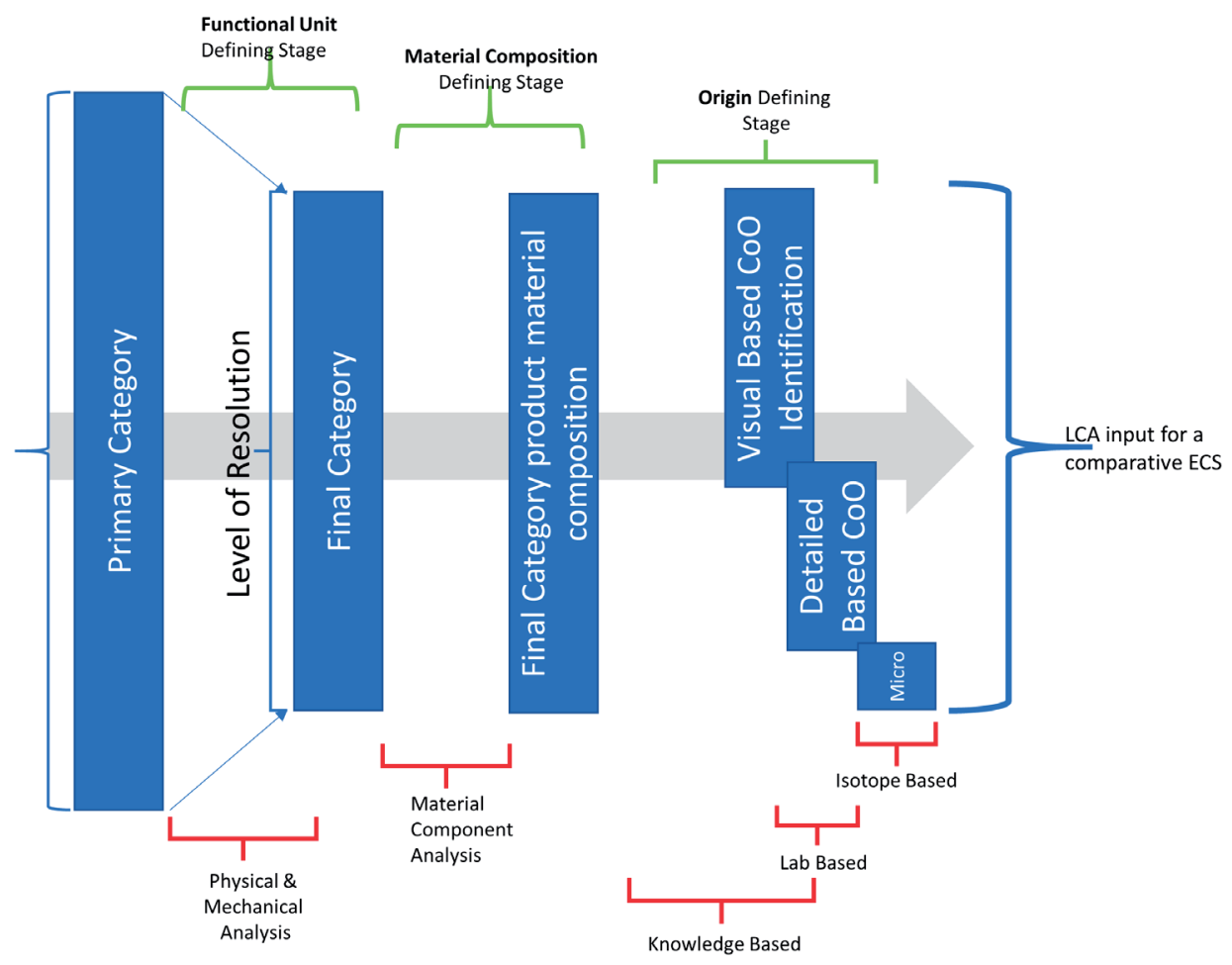

Figure 10.1: Functional Unit, Material Composition and Origin Stages (FUMCO)

It is evident that an amount of specific product and technologically relevant knowledge is required to understand and interpret the findings in the research into the functional unit, material composition and origin of an FSD product. In Chapter 8, it was argued that the identification of a material component within a product could lead to the identification of the process used to incorporate this component into the product, based on technologically relevant knowledge.

This chapter will also seek to understand the requirement for technologically relevant knowledge that was referred to in Chapter 4 with regard to ISO 14025, PEF and EPD, and became further evident in researching Chapter 7, 8 and 9. Reference will be made to this knowledge with regard to the LCA operative and objectivity of the claim maker.

The extent to which the lack of FSD product and technologically relevant knowledge can influence the relative position of an FSD product within a comparative ECS will be researched. 


\subsection{Knowledge}

There appears to be two fields of knowledge required when formulating a comparative ECS for FSD, these being:

1. Technologically Relevant Knowledge

2. Market Knowledge

This chapter will predominately focus on the technologically relevant knowledge with a brief reference to the market knowledge.

\subsubsection{Technologically Relevant Knowledge}

In Figure 10.2 below, the stages in which technologically relevant knowledge is required is highlighted. These are the LCA input development stages addressed by FUMCO.

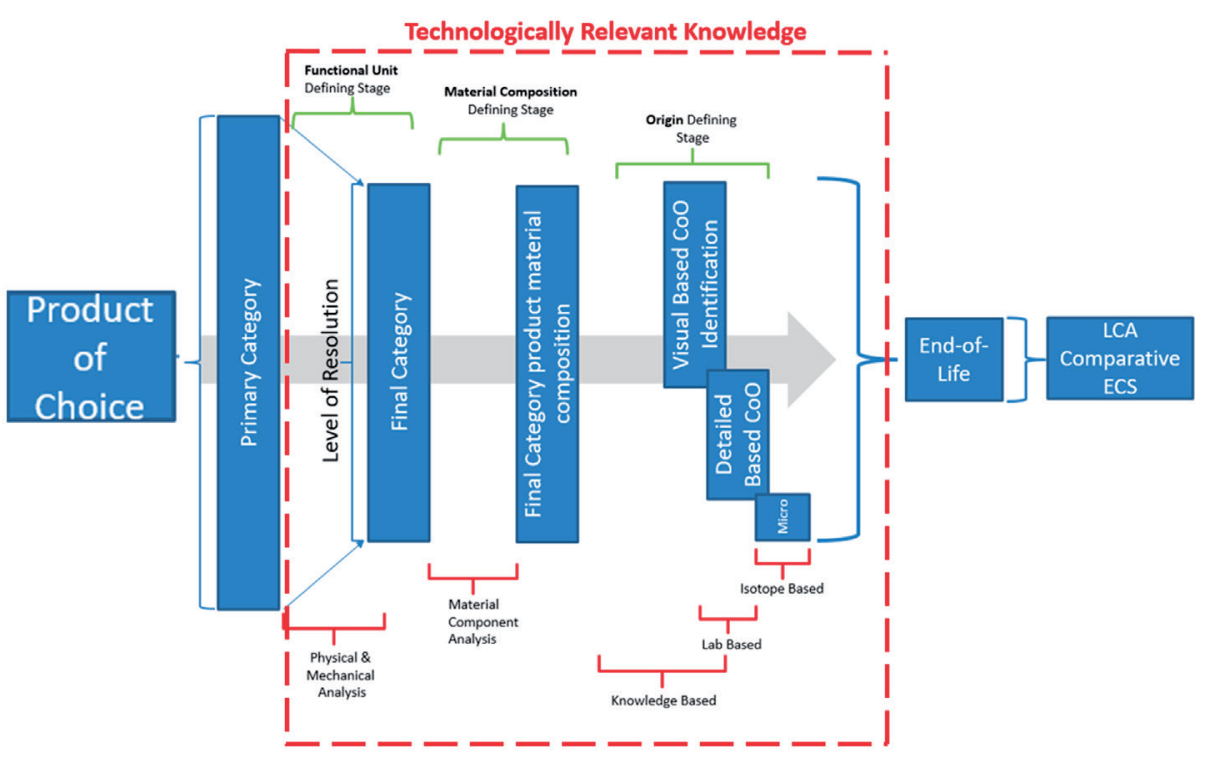

Figure 10.2: Technical Knowledge Stages required for Comparative ECS

\subsubsection{The Technologically Relevant Knowledge of the LCA Operative}

The role of the operative with technologically relevant knowledge in carrying out the analysis at each FUMCO stage and their interpretation of its outcome will be addressed in this subchapter.

FUMCO introduces a further requirement for technologically relevant knowledge in the process of preparing an LCA for use in a comparative ECS. In Chapter 4, a study of the 
requirements of ISO 14025, PEF and EDP was made in which a consistent reference was made to technical, product and process knowledge. This requirement for technologically relevant knowledge is argued in Baitz, M., et al., 2012, p. 7 as requiring to "reflect the industrial reality adequately".

Many of the materials and processes used to make FSD are the same as those used to make packaging; FSD are often referred to as food service packaging. In Van Sluisveld, M.A.E., et al., 2013, it is cited that there is a lack of packaging knowledge in the supply chain stating "that the main actor with detailed knowledge about packaging is often the supplier alone" (p. 139). In Lutters, D., et al., 2016, reference is made to the tendency to "underestimate the complexity of packaging" (Lutters, D., et al., 2016). Baumann, H., et al., 2004 states "One problem almost inherent to LCA is that no practitioner can be a technical expert on all the different technologies represented in a life cycle".

In Rebitzer, G., et al., 2004, it is argued that "the LCA practitioner may have little previous knowledge of the process for which data is to be compiled".

Lack of knowledge or ignorance can lead to unreliability and unrepresentative data in an LCA study (van der Harst-Wintraecken, E. J., 2015).

It has been cited that even bodies established to check claims are unlikely to understand their background technology or be able to approve them (Multi-Stakeholder Dialogue on Environmental Claims 2013).

This lack of technologically relevant knowledge was also evident in the Chapter 5 questionnaire in which the respondents indicated their reliance in general on stakeholder input.

FSD cover a wide range of functions, materials and processes. This would imply that the operative would have to have a wide knowledge of packaging technology with regard to functional testing, material science and processing. Further knowledge of testing to support $\mathrm{CoO}$ determination would also need to be available. Examples of the extent of this technical knowledge will be studied below.

It was stated at the EU PEF "Mid-Term Conference on the Environmental Footprint Pilot Phase" (Brussels, November 2015) that there was a shortage of knowledgeable LCA operatives. While LCA knowledge would also be a requirement of an operative studying FSD, this study does not seek to research the effect of LCA based knowledge but rather, as was previously mentioned, the effect of product economic inventory based knowledge as relates to LCA input for a comparative ECS. 
In the studies below, demonstration products are compared with a set category of like functionality products. In each case, the demonstration product is subject to the same omissions and incorrect economic inventory choices identified in scientific papers and published LCA studies in order to detect changes in the relative position of the product within a comparative ECS. The like functionality products in the category are chosen to be constant across the various studies of the different omissions and incorrect inventory choices cited in papers and LCA studies. It is not the intention to question the final results of these scientific papers and published LCA studies.

\subsubsection{Example of Cup Studies involving a Lack of Technologically Relevant Knowledge}

In the Hocking 1991 study involving paper cups, no petroleum feedstock was applied to the paper cup (Hocking, M. B., 1991). Paper cups are polymer coated (Van der Harst, E., et al., 2013). At the time of the Hocking study, they were mostly polyethylene coated; today, they are also to be found with biopolymer and acrylic lacquer coating (Lee, T. J., et al., 2017). Typical polyethylene coating weights are between 4 to $14 \%$ of the cup wall total weight (Stora Enso website, 2017).

Hocking's lack of accounting for the polyethylene coating in the paper cup could render his result lower than it would have been if the polyethylene had been accounted for. It is not possible to make an uncoated paper cup; the heat sealable coating is required to hold the cup together and make it water tight. Comments as to the reality of this cup construction were made in the paper by Ziada (Ziada, H., 2009).

Hocking's lack of accounting for the process waste in the paper cup could render his result lower than it would have been if the process waste had been accounted for. In the case of a plastic cup, the process waste is reprocessed back into the extruder; in the case of paper cups, the process waste is not reprocessed.

The following table was taken from the Hocking study in the Ziada 2009 study:

Table 10.1: Hocking Study of Cups

\begin{tabular}{l|c}
\multicolumn{1}{c}{ Cup Type } & \multicolumn{1}{c}{$\begin{array}{c}\text { Energy Use } \\
\text { (MM Btu/10 000 units) }\end{array}$} \\
\hline Re-usable Ceramic & 133.53 \\
\hline Re-usable Plastic & 59.71 \\
\hline Re-usable Glass & 52.14 \\
\hline Non-coated Paper & 5.20 \\
\hline Polystyrene & 1.87 \\
\hline
\end{tabular}


An observation regarding the Hocking study is that very different functions (re-useable versus disposable), materials and processes were compared. Had all the cups been paper cups of various weights and with various coatings, the calculation of the process waste would not have been important, as this would apply to all cups. However, the Hocking study includes both plastic cups and paper cups; this could require that the paper cup process waste be accounted for in a study of paper and plastic disposable cups.

Another study into hot beverage cups was the Design for the Environment 2009 study (DFE2009 Disposable Coffee Cups cited 10/10/2015) in which a variety of errors are made, such as the use of PLA and PET cups to hold hot coffee, the author choosing to use the extrusion temperature of the materials as the equivalent of their softening temperature and referring to PVC as the lining in the paper cups, which is incorrect.

OVAM (the Flemish waste disposal organization) carried out an eco-efficiency study (Vercalsteren, A., et al., 2006) of four types of cold beverage cups used at events. Reference is made to the "Production of PE coating layer" and "The cardboard cup is coated with a layer of LDPE" indicating that this is a single layer as would be used in cups for hot beverages, and not the typical two layer coated PE/paper/PE cup used for cold beverages (van der Harst-Wintraecken, E. J., 2015). The study states that "On average the PE-coating accounts for $5 \%$ of the total weight of the cup" which is also in line with a single PE layer; a typical two side coating would be 8 to 14\% (Stora Enso 2PE) depending on the cup weight. In this study, the cup weighs $7.7 \mathrm{~g}$ and is likely to use a paper with $12 \%$ by weight of polyethylene. The external polyethylene layer is necessary to avoid condensation being absorbed into the outer paper, which reduces the strength of the cup.

The OVAM study states that "The cardboard cup is coated with a layer of LDPE. In this process step the production of the LDPE-film (not the coating process itself) is taken into account." and "The paper and PE-film are transported from the respective production facilities to the company where the cups are produced". This could indicate that the LCA operative might assume that the polyethylene layer is applied by lamination in the cup converting facility and that it is not extrusion coated at the paper manufacturing plant.

The 2018 "Proposal for a DIRECTIVE OF THE EUROPEAN PARLIAMENT AND OF THE COUNCIL on the reduction of the impact of certain plastic products on the environment" (EU, COM (2018) 340/2 2018/0172 (COD)) was supported by an LCA study (Denkstatt, 2018). Within the study, the choice of paper cup material is described as Corrugated Board rather than the actual board type of Liquid Packaging Board or even Solid Bleach Board (Ligthart, T. N., et al., 2007). The study also refers to the paper cup lid as being made of LDPE when the actual material used is PS, or in some very unique cases PP. The study also states, for the cup and lid, that "the product is assumed to be injection molded".

These may be examples of "the LCA practitioner [having] little previous knowledge of the process for which data is to be compiled" (Rebitzer, G., et al., 2004). 
In the above mentioned cup studies, the following issues relating to the lack of technologically relevant knowledge was noted:

1. lack of PE coating on the paper cup (Hocking)

2. the choice of materials not found in cups (DFE, Denkstatt)

3. the choice of incorrect material combination profile for the function (OVAM)

4. incorrect material component application technology or manufacturing process (OVAM, Denkstatt)

5. lack of process waste for paper cup production (Hocking)

6. lack of consideration as to the function of the cup as would influence the material type (DFE)

In order to research the product economic inventory choices listed above, a target paper cup will be compared with the list of plastic drinking cups introduced in Chapter 6. These plastic drinking cups are made predominately from PP and weigh between $2.35 \mathrm{~g}$ to $2.7 \mathrm{~g}$. The Demonstration paper cup weights $4.86 \mathrm{~g}$ as would be typical in its design. The choice of plastic cups to compare with the Demonstration paper cups was based on the fact that each of the studies below also included plastic cups. Additionally, the choice of comparing with these plastic cups shows the effect of omitting the paper cup process waste which cannot be reprocessed in the manufacturing.

\subsubsection{Example of Likely Demonstration Cup}

As stated above, a paper cup has a polyethylene (PE) coating to seal the paper and provide a water barrier. Its manufacture also generates process waste which cannot re-enter the production process. This process waste is approximately 10\% (interviews Accum and Anbao, 2017); in this case, 10\% process waste will be assumed. In the Table 10.2 below, the likely Demonstration paper cup scenario is exhibited. For this study, the Star Rating bandwidths are set at $10 \%$.

Table 10.2: Likely Demonstration Paper Cup Product Inventory versus Plastic Drinking Cups

\begin{tabular}{c|c|c|c|c}
\hline Drinking Cups & ReCiPe Endpoints & Ratio to the Mean & Rank Order & Star Rating \\
\hline DC1 & 0.00129 & 1.12 & 6 & 2 \\
\hline DC2 & 0.00106 & 0.92 & 4 & 3 \\
\hline DC3 & 0.00113 & 0.98 & 7 & 2 \\
\hline DC4 & 0.00132 & 1.15 & 2 & 3 \\
\hline DC5 & 0.00100 & 0.87 & 1 & 3 \\
\hline DC6 & 0.00099 & 0.86 & 5 & 2 \\
\hline
\end{tabular}

This likely Demonstration cup above will be used for comparison with the other cups researched below. 


\subsubsection{Example of Hocking Demonstration Cup}

The Hocking study left out a polymer coating in the paper cup and made no reference to process waste. As an example of these two omissions in the product inventory, the following scenario exists when compared to the plastic drinking cups as shown below in Table 10.3.

Table 10.3: Hocking Demonstration Paper Cup Product Inventory versus Plastic Drinking Cups

\begin{tabular}{c|c|c|c|c}
\hline Drinking Cups & \multicolumn{1}{c}{ ReCiPe Endpoints } & Ratio to the Mean & Rank Order & Star Rating \\
\hline DC1 & 0.00129 & 1.14 & 3 & 2 \\
\hline DC2 & 0.00106 & 0.93 & 4 & 3 \\
\hline DC3 & 0.00113 & 0.99 & 7 & 2.5 \\
\hline DC4 & 0.00132 & 1.16 & 2 & 3 \\
\hline DC5 & 0.00100 & 0.88 & 1 & 3 \\
\hline DC6 & 0.00099 & 0.87 & 5 & 2.5 \\
\hline
\end{tabular}

In Table 10.3 above, the ReCiPe endpoint figures for the Hocking target cup is $7.2 \%$ below the likely Demonstration cup. The Star rating moves from 2 Stars to 2.5 Stars due to the omission of the PE coating and the process waste in the Hocking product inventory. These omissions influence the values associated with the various processes, transports and endof-life scenarios in the study. Omission of substances in the inventory data collection can have an effect on impact results.

This omission of PE and process waste does not affect the results of Hocking's study but is seen to affect the results when more comparable cups are studied, omissions being of variable importance depending on the scope of the study and resolution or sensitivity of the studied product category.

\subsubsection{Example of DFE Demonstration Cup}

In the Design for the Environment 2009 cup study (DFE2009 Disposable Coffee Cups), reference is made three times to the paper cup having a PVC lining and once to it being made of a PE coated paper. The use of PVC is highly unlikely for the typical coffee cup. In Table 10.4 below, PVC has been adopted in place of PE and 15\% process waste as defined in the DFE study. 15\% process waste would seem high given that most processes to make paper cups would incur approximately $10 \%$ process waste. 
Table 10.4: DFE Paper Cup Product Inventory versus Plastic Drinking Cups

\begin{tabular}{c|c|c|c|c}
\hline Drinking Cups & ReCiPe Endpoints & Ratio to the Mean & Rank Order & Star Rating \\
\hline DC1 & 0.00129 & 1.11 & 5 & 2 \\
\hline DC2 & 0.00106 & 0.92 & 3 & 3 \\
\hline DC3 & 0.00113 & 0.98 & 4 & 2.5 \\
\hline DC4 & 0.00132 & 1.14 & 7 & 3 \\
\hline DC5 & 0.00100 & 0.86 & 1 & 3 \\
\hline DC6 & 0.00099 & 0.86 & 6 & 2 \\
\hline
\end{tabular}

In Table 10.4 above, the ReCiPe endpoint figures for the DFE Demonstration cup is 4.6\% above the likely Demonstration cup. The choice of PVC increases the endpoint score by $2.4 \%$ with the remaining increase coming from processes associated with the PVC weight and the adoption of $15 \%$ process waste. PVC has a higher density than PE and this increases the weight of the plastic layer within the cup, which also leads to the necessary reduction in the weight of the liquid packaging board, to maintain the original overall cup weight. The Rank Order number drops by one position due to the inclusion of PVC in place of PE and the increased process waste.

In the DFE study, the PVC coated paper cup is then compared with an APET and PLA cup for hot coffee. While these types of cups exist for cold beverages, they would not function with hot liquids (Franklin, Foodservice LCA Study, 2011) as they would soften to the point of being unfunctional. This omission to consider the ability for all cups to function when used for hot coffee is important. It could be questioned if the people carrying out the DFE study actually tested the cups for their reported function.

Drinking and vending cups in PP and PS are common; their HDT are respectively 100 and $95^{\circ} \mathrm{C}$ (Heat Deflection Temperature at $0.46 \mathrm{MPa}\left({ }^{\circ} \mathrm{C}\right)$ )

(source: http://www.matweb.com/reference/deflection-temperature.aspx 07/04/2018).

PET has an HDT of $70^{\circ} \mathrm{C}$ (matweb) and PLA has an HDT of $55^{\circ} \mathrm{C}$ (Nagarajan, $V_{\text {., }}$ et al., 2016). HDT is the temperature at which material loses its load bearing capacity which is of significant importance in terms of designing a cup to hold hot beverages that risks spilling and potential injury. The importance of considering product functionality was researched in Chapter 7.

To research the significance of this lack of functional consideration on the results of a comparative study, a $6.5 \mathrm{~g}$ PLA cup and a $6.5 \mathrm{~g}$ APET cup were identified in the market and were applied to the study. The APET cup was accounted for as being sourced in Poland and the PLA cup from Germany, as is typical for these types of cups. Both PLA and PET are polyesters that require drying before processing; this has been considered in the research. PLA material is sourced from the USA. 
As can be seen in Tables 10.5 and 10.6 below, these APET and PLA cups exhibit a considerably higher ReCiPe figure than the likely demonstration paper cup in the comparison.

Table 10.5: DFE APET Cup Product Inventory versus Plastic Drinking Cups

\begin{tabular}{c|c|c|c|c}
\hline Drinking Cups & \multicolumn{1}{c}{ ReCiPe Endpoints } & \multicolumn{2}{c}{ Ratio to the Mean } & Rank Order \\
\hline DC1 & 0.00129 & 0.85 & 5 & 3.5 \\
\hline DC2 & 0.00106 & 0.70 & 4 & 4 \\
\hline DC3 & 0.00113 & 0.75 & 6 & 4 \\
\hline DC4 & 0.00132 & 0.87 & 2 & 3 \\
\hline DC5 & 0.00100 & 0.66 & 1 & 4 \\
\hline DC6 & 0.00099 & 0.66 & 7 & 4 \\
\hline Demo DFE aPET & 0.00378 & 2.50 & & 0 \\
\hline
\end{tabular}

Table 10.6: DFE PLA Cup Product Inventory versus Plastic Drinking Cups

\begin{tabular}{c|c|c|c|c}
\hline Drinking Cups & \multicolumn{1}{c}{ ReCiPe Endpoints } & Ratio to the Mean & Rank Order & Star Rating \\
\hline DC1 & 0.00129 & 0.90 & 5 & 3 \\
\hline DC2 & 0.00106 & 0.74 & 4 & 4 \\
\hline DC3 & 0.00113 & 0.79 & 6 & 3.5 \\
\hline DC4 & 0.00132 & 0.92 & 2 & 3 \\
\hline DC5 & 0.00100 & 0.70 & 1 & 4 \\
\hline DC6 & 0.00099 & 0.69 & 7 & 0 \\
\hline
\end{tabular}

PLA is certified as an industrially compostable plastic; this end-of-life scenario was not considered in this study. All end-of-life scenarios throughout this study are based on incineration unless otherwise stated, incineration being the common end-of-life scenario of FSD in the Netherlands.

The PET and PLA cups cannot be considered to have the same functionality as the other hot beverage cups, so any comparison would seem of little value. The above rankings could influence the perceived value of these two cups that could have ranked better in the study of their like functionality type products, in this case possibly a disposable clear cold beverage glass category. 


\subsubsection{Example of OVAM Target Cup}

The OVAM study compares cold beverage cups but appears to use a single side PE laminated paper construction rather than double sided extrusion coated polyethylene as described above.

The calculation in Table 10.7 below included the OVAM Demonstration cup with two sides PE lamination in place of one side polyethylene coating. The process waste is accounted for at $8 \%$ as is cited within the OVAM study.

Table 10.7: OVAM Paper Cup Product Inventory versus Plastic Drinking Cups

\begin{tabular}{c|c|c|c|c}
\hline Drinking Cups & ReCiPe Endpoints & Ratio to the Mean & Rank Order & Star Rating \\
\hline DC1 & 0.00129 & 1.11 & 5 & 2 \\
\hline DC2 & 0.00106 & 0.92 & 3 & 3 \\
\hline DC3 & 0.00113 & 0.98 & 4 & 2 \\
\hline DC4 & 0.00132 & 1.14 & 7 & 2 \\
\hline DC5 & 0.00100 & 0.86 & 2 & 3 \\
\hline DC6 & 0.00099 & 0.86 & 1 & 2 \\
\hline
\end{tabular}

In Table 10.7 above, the ReCiPe endpoint figures for the OVAM demonstration cup is 4.58\% above the likely Demonstration cup which moves its Rank Order position down by one.

\subsubsection{Other Issues regarding Cup Studies}

Of concern is the possibility that cups from such studies could be adopted in new cup studies hence perpetuating the original erroneous inventory and rendering comparative study results questionable. It could be that a comparative study of five cups should start with a knowledgeable study of the inventory of each cup rather than relying on such inventory taken from previous studies, especially if this inventory is not clearly identified in the previous study.

Peer review can help if the reviewer has the appropriate knowledge to identify any erroneous inventory data. Alternatively, the peer reviewer may sight the use of an incorrect material in a study and the study author may choose to continue to use the incorrect material (Ligthart, T. N., et al., 2007) as it does not affect the outcome of their study. It is possible that, when this same material is carried forward to be used in a further study, it may have consequences for the result of that study. 
A noticeable trend is the use of non-peer reviewed studies provided with the various new cup offerings, an example being SUEZ Cup2Paper LCA (Partners For Innovation 22-04-2016).

While it is possible that these types of studies could be said to generate results to favour the specific material or process of the sponsor of the LCA (Bras-Klapwijk, R., 1999), it is noted that product inventory can play a role in doing so. In this SUEZ case, a PLA coated paper cup is compared to a PE coated paper cup; the PE version included $27 \%$ process waste and the PLA version accounted for no process waste, while both cup forming processes are the same.

The choice of $27 \%$ waste is possibly not random, as this amount is referred to in the often cited TNO study (Ligthart, T. N., et al., 2007). The TNO report states that the $27 \%$ waste figure is derived from "punching and startup losses". Paper cup forming process waste is approximately $10 \%$ (interviews Accum and Anbao, 2017); as process waste cannot be reabsorbed into the cup forming process, it is a loss that is minimized by design, as can be seen in the punched blank layout in Figure 10.9 below.

Information received from manufacturers, reported in LCA studies, can also be incorrect, as in the following statement from a PE Americas Study (PE Americas, 2009) that compared PLA, PP and PET drinking cups:

"Based on discussion with the cup manufacturer, no significant difference in energy consumption for PLA is expected".

While there are some similarities between PLA and PET, PP that is not mixed with fillers requires no pre-drying (Ineos Olefins \& Polymers USA, Polypropylene Processing Guide); however, PLA is recommended to be dried for $24 \mathrm{hrs}$ at around $40^{\circ} \mathrm{C}$ (Corbion Processing Guide Rev.No. 1). There is no mention of drying of the plastic granules in the study. While there are other differences between these two materials that are not mentioned in this study, the concern is that these missing or incorrectly assumed processes can be taken forward into later studies.

Another concern as relates to these cup studies is potentially one of linguistics, in which the same sounding word in one language can have a different meaning in another. In HarstWintraecken, reference is made to a PLA extrusion coated paper cup being "manufactured in a sequence of punching, folding, and gluing"; extrusion coated paper cups are not glued but heat sealed, no glue is required (Harst-Wintraecken, E. J. Van der, 2015). It is also noted that PE extrusion coated cups are sometimes referred to as being laminated, as mentioned in the above OVAM study; it is possible that the distinction between extrusion coating and laminating is not clearly understood by the LCA operative. Quantification of the differences in both these cases could lead to other outcomes in comparative product studies. Do these linguistic issues influence data choices? A common example in the 
Dutch language is the use of the term "folie" to mean film. It actually translates as foil, which would commonly be associated with aluminium foil in English.

The choice of board type used in the study of paper cups varies across studies (HarstWintraecken, E. J. Van der, 2015). In the studies of Franklin, 2006 and Vercalsteren et al., 2006, bleach board was taken to be the paper cup board type, whereas in the Ligthart, T. N., et al., 2007 study, liquid packaging board is adopted as the board type for the cups. Bleached board is typically the name given to cup stock board in the USA, whereas Liquid Packaging Board is the more typical name given in the EU. Hence, both board types could be used but could better be allocated to the territory in which the name is used. Do issues of semantics influence data choices?

Industries and technologies apply jargon which may lead to an LCA operative, devoid of technologically relevant knowledge, making incorrect data choices.

\subsubsection{Conclusion Cups}

The lack of technologically relevant knowledge within a study of cups, as regards the product economic inventory, can be seen to affect the relative position of cups within a comparative ECS.

In the Merugula, L. study (Merugula, L., 2013), the Hocking inventory is cited as "reasonably detailed" and the OVAM inventory as "high detail" (p. 106) and yet basic inventory were seen to be missing, possibly due to the lack of product technical knowledge.

Issues of linguistics, jargon and semantics could be seen to further confuse and potentially influence product inventory data choices.

\subsubsection{Example of Lack of FSD Technologically Relevant Knowledge in a Cutlery Study}

FSD plastic cutlery is manufactured using an injection moulding process. Knowledge that this is the process to apply to the study is important.

On page 14 of the Plastic ZERO - Public Private Cooperation's for Avoiding Plastic as a Waste- LCA study into "Comparing disposal versus reuse of food packaging" for various cities public procurement, such as Copenhagen and Malmo, thermoforming was chosen in the LCA as the method to make plastic cutlery.

(http://www.plastic-zero.com/media/58705/lca_eat_project_report_july_2014_action_4.2.pdf cited 18/02/2016).

This type of incorrect choice is an example of the lack of technologically relevant knowledge mentioned above. Thermoforming takes place after sheet extrusion and yet no sheet extrusion was mentioned in the report or its inventory ("Ecoinvent database entries used in the modelling", p. 16). 
If thermoforming is used in place of injection moulding, the associated energy requirement for thermoforming would be lower than for injection moulding. Cutlery is often made in Asian countries, such as China, whose electricity is listed as having a relatively high environmental impact (Ecoinvent v3.4).

In Table 10.8 below, the injection moulding process was removed from fork number 8 , which sits at near the half way point in the rank order, and was replaced with a thermoforming process. This incorrect process choice has significant effect on the relative position of fork number 8 in a comparable ECS, as can be seen marked below in yellow for the Rank Order number and Star Rating. The associated Star Rating bandwidth is 10\% in this study.

Table 10.8: The Change to Fork No.8 Position Due to the Incorrect Choice of Thermoforming

All forks injection moulded

\begin{tabular}{c|c|c|c|c|c|c|c|c}
\hline Forks & \multicolumn{1}{c}{$\begin{array}{c}\text { ReCiPe } \\
\text { Endpoints }\end{array}$} & \multicolumn{1}{c}{$\begin{array}{c}\text { Ratio to } \\
\text { the Mean }\end{array}$} & \multicolumn{1}{c}{$\begin{array}{c}\text { Rank } \\
\text { Order }\end{array}$} & \multicolumn{1}{c}{$\begin{array}{c}\text { Star } \\
\text { Rating }\end{array}$} & \multicolumn{2}{c}{$\begin{array}{c}\text { ReCiPe } \\
\text { Endpoints }\end{array}$} & \multicolumn{1}{c}{$\begin{array}{c}\text { Ratio to } \\
\text { the Mean }\end{array}$} & \multicolumn{2}{c}{$\begin{array}{c}\text { Rank } \\
\text { Order }\end{array}$} & $\begin{array}{c}\text { Star } \\
\text { Rating }\end{array}$ \\
\hline 1 & 0.00142 & 0.69 & 2 & 4 & 0.00142 & 0.71 & 3 & 4 \\
\hline 2 & 0.00133 & 0.65 & 1 & 4.5 & 0.00133 & 0.67 & 1 & 4 \\
\hline 3 & 0.00427 & 2.09 & 9 & 0 & 0.00427 & 2.14 & 9 & 0 \\
\hline 4 & 0.00145 & 0.71 & 3 & 4 & 0.00145 & 0.73 & 4 & 4 \\
\hline 5 & 0.00189 & 0.92 & 6 & 3 & 0.00189 & 0.95 & 6 & 3 \\
\hline 7 & 0.00186 & 0.91 & 5 & 3 & 0.00186 & 0.93 & 5 & 3 \\
\hline 8 & 0.00182 & 0.89 & 4 & 3 & 0.00140 & 0.70 & 2 & 4 \\
\hline
\end{tabular}
No.8 which is thermoformed

All forks injection moulded except 
Thermoformed Fork No.8

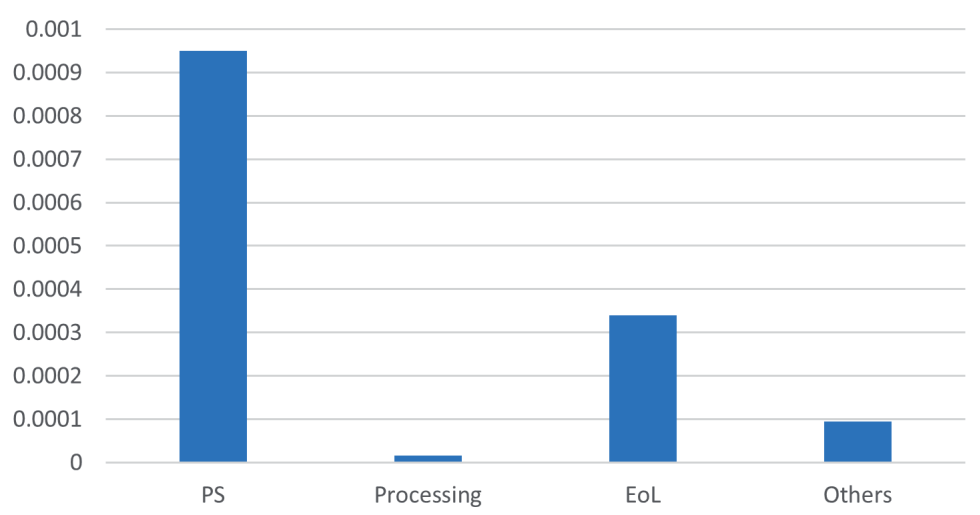

Figure 10.4: ReCiPe Endpoints per Life Cycle Stages for the Thermoformed Fork No.8

Figures 10.3 and 10.4 above illustrates the significance of the Plastic ZERO error.

This specific study based on the Plastic ZERO error does not intend to show the impact this error had on the final conclusion of their study whose goal was to compare an item with its re-usable equivalent.

The lack of technically relevant knowledge in this case meant that a document, destined to aid in understanding choices within public procurement, contained incorrect values for disposable cutlery.

This may also be the case as regards the EU Plastic Strategy LCA study mentioned above (Denkstatt, 2018) in which various material choices were not relevant to the products under study. In this Denkstatt study, the choice of material for the stirrer cutlery item is PP, which would not typically function as a stirrer as it would not remain rigid and would curl in a hot beverage as can be seen in Figure 7.6. It could be questioned as to the value of this study in aiding the establishment of EU law, such as the eventual rule to ban certain FSD items.

\subsection{2cm Plates - Process Waste}

In Chapter 7 , the $22 \mathrm{~cm}$ plate category was introduced, being made up of plastic and paper plates.

The paper plates could be assumed to have been cut from a sheet or roll resulting in skeletal waste that cannot be reabsorbed back into the process. Plastic process waste is typically reprocessed within the production.

Paperboard cutting processes can commonly be from the sheet, as is evident in some printed paper board cake box manufacturing processes. In the case of these unprinted paper plates, the process would more likely be based on a roll. 
The result of the correct choice of a roll fed production of the plates, in place of a sheet fed production, has implications for the skeletal waste quantity in the product inventory.

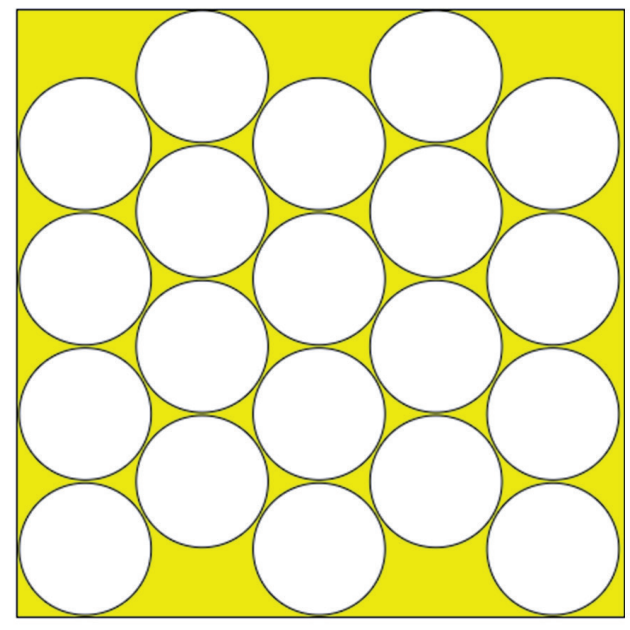

Figure 10.5: Circle Layout within a Sheet

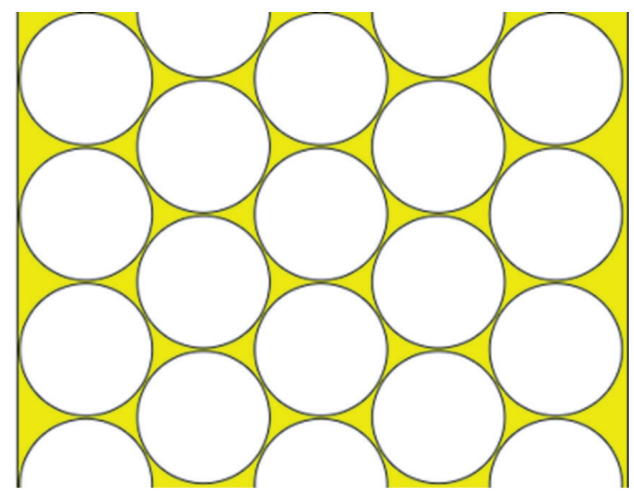

Figure 10.6: Circle Layout within a Roll 
In the following calculations, an infinite number of plates of diameter $d$ are being considered and the space for and thickness of the cutter blades are not being taken into account.

1. For sheet fed plate production and taking 20 plates to a sheet (see Figure 10.5 above), a sheet of width $4.464 \mathrm{~d}$ and length $4.5 \mathrm{~d}$ is required for the sheet to be tightly packed around the plates. If this is achieved, the waste figure is $21.8 \%$.

2. For roll fed plate production with roll width $4.464 \mathrm{~d}$ and infinite length, the waste seen at the top and bottom of Figure 10.5 will be absorbed by 3 plates above and 2 plates below, as can be seen in Figure 10.6 above. Thus, 22.5 plates can now be considered to be the amount of plates to fit within the equivalent of the sheet area on the roll. The waste figure is now reduced to $12 \%$.

Calculations to support the above percentage waste figures are in Appendix J.

In Table 10.9 below, the result of the above described $21.8 \%$ and $12.0 \%$ skeletal waste is applied to the paper plates in a mixed category of plastic and paper plates. Moving from a paper plate with $21.8 \%$ skeletal waste to $12.0 \%$ skeletal waste has decreased the ReCiPe endpoint value and the associated mean which has changed the Star Rating of three of the plates within the $12 \%$ skeletal waste category. A move from $12 \%$ skeletal waste to $0 \%$ waste changes the Star rating of the paper plate, while, in every case, the Rank Order position remains the same.

An operative with little product knowledge could potentially simply weigh the plates and not consider additional weight in the form of process waste. This would result in an increase in Star Rating when comparing 0\% skeletal waste to the $21.8 \%$ skeletal waste based plate, as can be seen below in Table 10.9.

It could be possible that this type of process waste omission could fuel perception that one material is more efficient than the other without reference to its yield in producing an FSD. When $21.8 \%$ skeletal waste is used, the first two PS plates have the same Star Rating as the paper plate, when $12 \%$ and $0 \%$ skeletal waste is chosen, the paper plate is seen to score better than the first two PS plates.

\subsubsection{2cm Plates - Process Waste - Conclusion}

The knowledge that paper plates are cut from sheets or rolls and that the associated skeletal waste cannot be reincorporated in the process, unlike for plastic plates, drives a requirement for a waste figure to be added to the paper plate life cycle. If the operative is unaware of this then they will adopt $0 \%$ waste in their inventory.

If they are aware that they would need to calculate a waste figure, if they based this on sheet fed production, the waste would be $21.8 \%$ but if they based this on a roll fed production, the waste would be $12.0 \%$. This makes a significant difference to the weight 


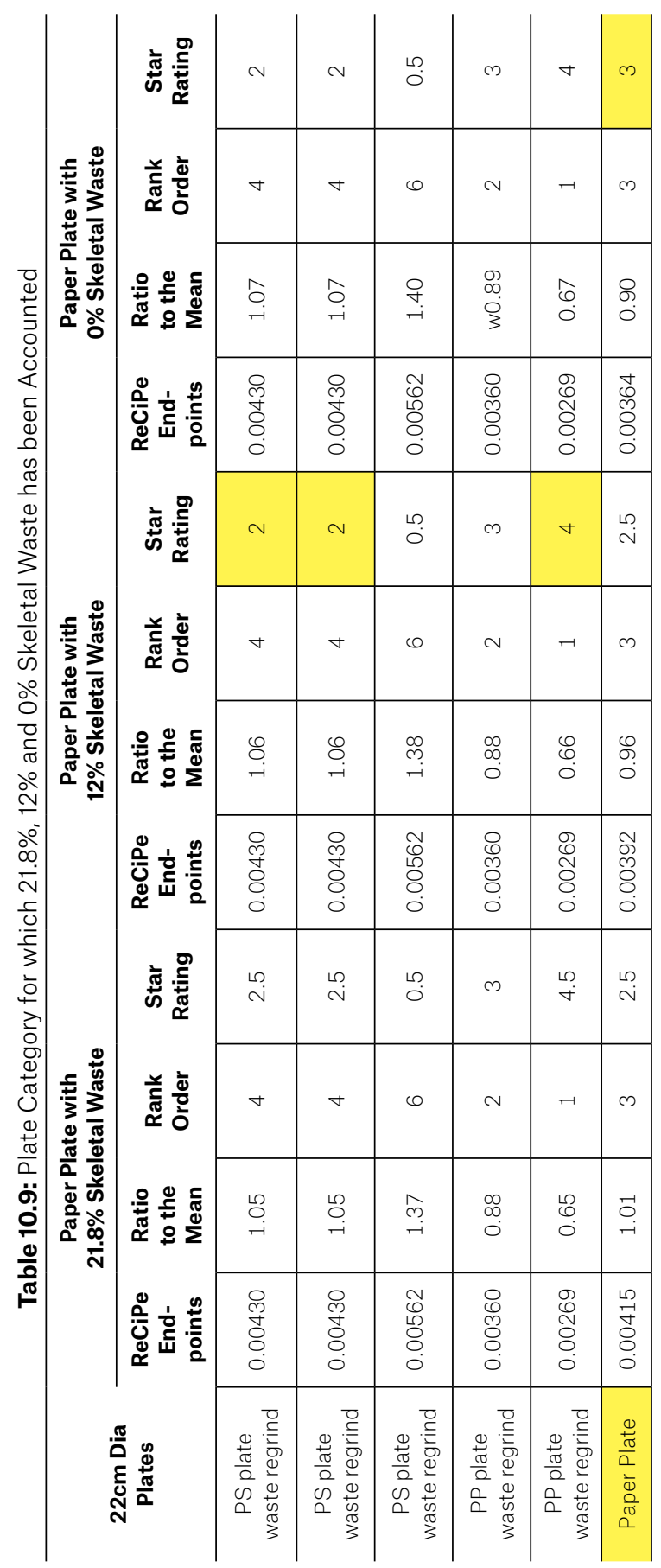


of material required to manufacture the paper plates and hence the product economic inventory for input to the LCA. The difference also leads to a Star Rating change of half of the plates in the category.

\subsection{8oz Double Wall Paper Cup and Lid}

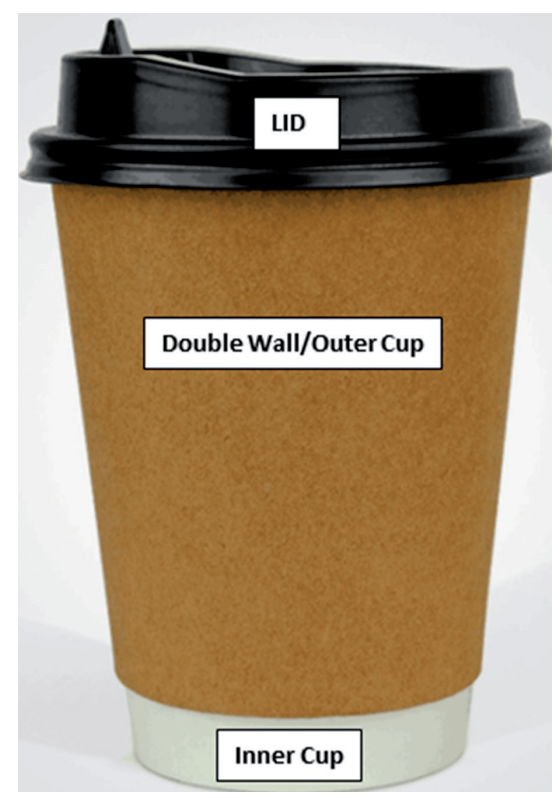

Figure 10.7: 8oz Double Wall Cup and Lid

Specialty coffee is a term referring to the type of on-the-go coffee purchased from branded coffee retailers or coffee shops. Typically, coffee is sold in paper cups; these are often double wall cups to offer greater comfort to the customer as regards the touch temperature of the cup when it is filled with hot beverage. A lid is then regularly applied to the cup to avoid spillage when the cup is being carried and to facilitate drinking while in motion.

To what extent would simply weighing the double wall cup (DWC) and then the plastic lid, to establish product inventory input, affect the relative position of the cup within a comparative ECS?

To what extent could the lack of technologically relevant knowledge contribute to cumulative inventory data choice inaccuracy of multi-component products like the cup in Figure 10.7? 


\subsubsection{The Lid}

This subchapter will address the issues of material type and weight variance as regards the paper cup lid which could lead to variances in product economic inventory input to LCA.

Common lids for these paper cups are made of high impact polystyrene (HIPS) or polypropylene (PP) to which a masterbatch is added, depending on their colour. They are manufactured to a weight tolerance. This tolerance is associated with the design specification, indicating a level of weight variability that will not compromise performance of FS.

The typical $80 z$ lid weighs $2.6 \mathrm{~g}$ with a weight tolerance of $10 \%$. In Figure 10.8 below, 120 HIPS lids were weighed, these being from the same production batch (CSCI Pacli, 2017). The average weight of this range of lids was $2.65 \mathrm{~g}$, with the lowest weight range value being $2.43 \mathrm{~g}$ and the highest weight range value being $2.81 \mathrm{~g}$.

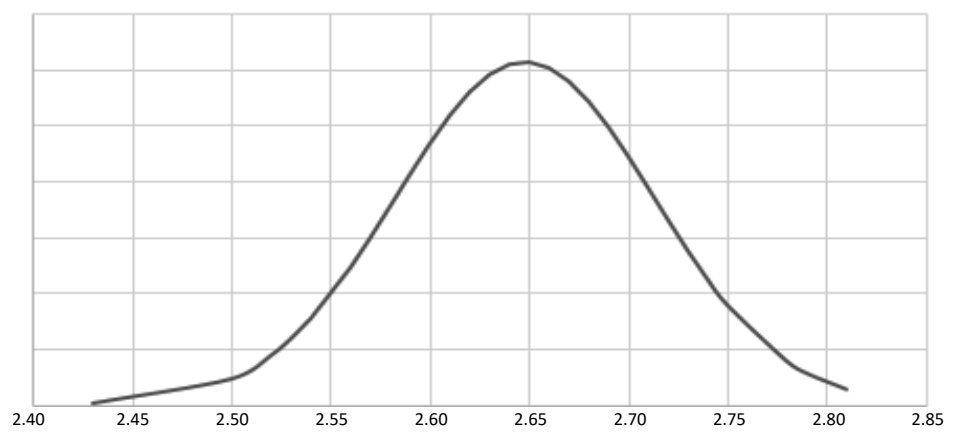

Figure 10.8: Spread of Weights across $12080 z$ Lids

A study over 11 production batches indicated an average weight of 120 lids as being $2.59 \mathrm{~g}$, with the average lowest weight being $2.37 \mathrm{~g}$ and the average highest weight being $2.84 \mathrm{~g}$, resulting in a process variability of close to $10 \%$, as reported for the lid weight tolerance. Therefore, relying on the weighing of a single lid could misrepresent the impact of the lid, due to a weight variance of $10 \%$ from the intended average or target weight of the lid. 
Table 10.10: Lower and Upper Tolerance plus Average 8oz Lid Weights over 11 Production Batches

Lid Weight (g)

\begin{tabular}{c|c|c|c}
\hline Date & Lowest & Highest & Average \\
\hline 15-Aug & 2.40 & 2.80 & 2.57 \\
\hline 14-Aug & 2.55 & 2.83 & 2.71 \\
\hline 14-Aug & 2.40 & 2.80 & 2.63 \\
\hline 13-Aug & 2.34 & 2.85 & 2.62 \\
\hline 12-Aug & 2.37 & 2.83 & 2.63 \\
\hline 11-Aug & 2.44 & 2.82 & 2.64 \\
\hline 11-Aug & 2.38 & 2.83 & 2.65 \\
\hline 9-Aug & 2.50 & 2.85 & 2.70 \\
\hline 8-Aug & 2.34 & 2.85 & 2.67 \\
\hline 8-Aug & 2.34 & 2.80 & 2.64 \\
\hline Average & $\mathbf{2 . 3 7}$ & $\mathbf{2 . 8 4}$ & $\mathbf{2 . 5 9}$ \\
\hline
\end{tabular}

To research the effect of this tolerance on the $80 z$ cup lid, each of the weights in Table 10.10 above has been calculated for both PP and HIPS lids using ReCiPe endpoints, as can be seen in Table 10.11 below. This includes the material and white masterbatch, manufacturing processes, transports and end-of-life scenario.

While this lid research is purely to show the value of correctly identifying the primary material of the lid and taking account of tolerance, it is added to the DWC and lid research. This could then indicate the significance of compounding incorrect materials based assumptions as regards the DWC and lid, due to the potential lack of technical knowledge of the product. 
Table 10.11: ReCiPe Endpoints associated with Upper, Lower and Average Weights for PP and HIPS Lids

\begin{tabular}{|c|c|c|c|c|c|c|}
\hline \multirow{3}{*}{$\begin{array}{l}\text { Lids } \\
\text { Date }\end{array}$} & \multicolumn{6}{|c|}{ ReCiPe Endpoints } \\
\hline & \multicolumn{2}{|c|}{ Lowest Weight } & \multicolumn{2}{|c|}{ Highest Weight } & \multicolumn{2}{|c|}{ Average Weight } \\
\hline & PP & HIPS & PP & HIPS & PP & HIPS \\
\hline 15-Aug & 0.000144 & 0.000180 & 0.000168 & 0.000210 & 0.000154 & 0.000193 \\
\hline 14-Aug & 0.000153 & 0.000191 & 0.000170 & 0.000212 & 0.000163 & 0.000203 \\
\hline 14-Aug & 0.000144 & 0.000180 & 0.000168 & 0.000210 & 0.000158 & 0.000197 \\
\hline 13-Aug & 0.000140 & 0.000176 & 0.000171 & 0.000214 & 0.000157 & 0.000197 \\
\hline 12-Aug & 0.000142 & 0.000178 & 0.000170 & 0.000212 & 0.000158 & 0.000197 \\
\hline 11-Aug & 0.000146 & 0.000183 & 0.000169 & 0.000212 & 0.000158 & 0.000198 \\
\hline 11-Aug & 0.000143 & 0.000179 & 0.000170 & 0.000212 & 0.000159 & 0.000199 \\
\hline 09-Aug & 0.000150 & 0.000188 & 0.000171 & 0.000214 & 0.000162 & 0.000203 \\
\hline 08-Aug & 0.000140 & 0.000176 & 0.000171 & 0.000214 & 0.000160 & 0.000200 \\
\hline 08-Aug & 0.000140 & 0.000176 & 0.000168 & 0.000210 & 0.000158 & 0.000198 \\
\hline Average & 0.000142 & 0.000178 & 0.000170 & 0.000213 & 0.000155 & 0.000194 \\
\hline
\end{tabular}

Based on the research in Table 10.11 above, it could be entirely possible that, through the incorrect choice of material type and the extremes of the tolerance, a difference could exist of $34.57 \%$ in the ReCiPe endpoint value of the lid, 34.57\% being the difference between the PP lid lowest weight achieved on 13th August compared with the HIPS highest weight achieved on the same date, both marked in yellow above.

The source of the lid can also vary from that of the cup; typically, cup manufacturers do not manufacture lids as a different production technique is required. Hence, any potential assumption by the LCA operative of the lid source being the same as the cup source could be questioned. In the above calculations in Table 10.11, both the PP and HIPS lids were taken to be made in China, which is a common source of such lids.

\subsubsection{The Outer Cup of the Double Wall 8oz Cup}

This subchapter will address the issues of DWC outer wall construction as could lead to variances in product economic inventory input to LCA.

To provide insulation when in use, the DWC has an outer wall, which is essentially a second cup with a slightly larger diameter and no base into which the inner cup is attached.

This outer cup is typically printed and is then die cut into blanks prior to being fed into a cup forming machine which seals the spine of the outer cup. 
A typical outer cup for an $80 z$ DWC could be a $230 \mathrm{gsm}$ board with an $18 \mathrm{gsm}$ PE extrusion coating on the inside, similar to the inner cup material. However, the outer cup material is often exclusively board with no PE and is sealed using a heat sealable varnish printed on to the reverse side of the blank. Alternatively, a hot melt glue line is applied to the spine prior to sealing.

An outer cup PE extrusion coated blank could weigh $4.57 \mathrm{~g}$, making a $25 \%$ contribution to the overall DWC weight which could be $13.5 \mathrm{~g}$. In a study of DWCs, accounting for how the outer cup is made would hence appear to be of value.

All outer cup blanks are subject to the same processes of printing, die cutting and cup forming. However, to facilitate the different approaches to sealing the spine of the outer cup, different conversion processes are required:

1. The PE coated heat sealing option involves extrusion coating of PE across the complete inner surface of the outer wall cup.

2. The varnish printed sealant would typically be printed onto the inner surface of the outer wall cup. This requires printing on the reverse side of the board which may require two passes in the print process if a specific coating station was not available. This inner surface would then not need to be PE coated.

3. The hot melt glue sealing approach would require no coating processing prior to forming. Within the forming process, a hot melt applicator would apply hot melt adhesive to the spine area prior to sealing.

In Table 10.12 below, the ReCiPe endpoints are calculated, for a series of 9 DWCs, for the outer cup wall based on a PE extruded coated board and a board on to which hot melt is added during forming.

Table 10.12: Outer Cup Material Options represented in ReCiPe Endpoints

\begin{tabular}{c|c}
\hline \multicolumn{2}{c}{ Board+PE Outer Cup } \\
\hline $\begin{array}{c}\text { Outer Cup } \\
\text { No }\end{array}$ & $\begin{array}{c}\text { ReCiPe } \\
\text { Endpoints }\end{array}$ \\
\hline 1 & 0.00096 \\
\hline 2 & 0.00096 \\
\hline 3 & 0.00113 \\
\hline 4 & 0.00113 \\
\hline 5 & 0.00113 \\
\hline 6 & 0.00107 \\
\hline 7 & 0.00119 \\
\hline 8 & 0.00113 \\
\hline 9 & 0.00126 \\
\hline
\end{tabular}

\begin{tabular}{c|c}
\hline \multicolumn{2}{c}{ Board only Outer Cup } \\
\hline $\begin{array}{c}\text { Outer Cup } \\
\text { No. }\end{array}$ & $\begin{array}{c}\text { ReCiPe } \\
\text { Endpoints }\end{array}$ \\
\hline 1 & 0.00088 \\
\hline 2 & 0.00088 \\
\hline 3 & 0.00102 \\
\hline 4 & 0.00102 \\
\hline 5 & 0.00102 \\
\hline 6 & 0.00098 \\
\hline 7 & 0.00109 \\
\hline 8 & 0.00105 \\
\hline 9 & 0.00117 \\
\hline
\end{tabular}


It should then be noted that cup stock board has a tolerance of 3\% (Stora Enso, 2017) which should also be considered as regards the weight of the outer cup, as was the case with the lid. In Table 10.13 below, the difference in outer cup wall material and the 3\% tolerance have been researched and the figures have been displayed in ReCiPe endpoints.

Table 10.13: Outer Cup Material Options at Lower and Upper Tolerance Weights represented in ReCiPe Endpoints

\begin{tabular}{c|c|c}
\hline \multirow{2}{*}{$\begin{array}{c}\text { Buter Cup } \\
\text { No. }\end{array}$} & $\begin{array}{c}\text { Lower } \\
\text { Tolerance }\end{array}$ & $\begin{array}{c}\text { Upper } \\
\text { Tolerance }\end{array}$ \\
\cline { 2 - 3 } & $\begin{array}{c}\text { ReCiPe } \\
\text { Endpoints }\end{array}$ & $\begin{array}{c}\text { ReCiPe } \\
\text { Endpoints }\end{array}$ \\
\hline 1 & 0.00093 & 0.00099 \\
\hline 2 & 0.00093 & 0.00099 \\
\hline 3 & 0.00110 & 0.00116 \\
\hline 4 & 0.00110 & 0.00116 \\
\hline 5 & 0.00110 & 0.00116 \\
\hline 6 & 0.00104 & 0.00110 \\
\hline 7 & 0.00115 & 0.00123 \\
\hline 8 & 0.00110 & 0.00116 \\
\hline 9 & 0.00122 & 0.00130 \\
\hline
\end{tabular}

\begin{tabular}{c|c|c}
\hline \multicolumn{3}{|c}{ Board only Outer Cup } \\
\hline $\begin{array}{c}\text { Outer Cup } \\
\text { No. }\end{array}$ & $\begin{array}{c}\text { Lower } \\
\text { Tolerance }\end{array}$ & $\begin{array}{c}\text { Upper } \\
\text { Tolerance }\end{array}$ \\
\cline { 2 - 3 } & $\begin{array}{c}\text { ReCiPe } \\
\text { Endpoints }\end{array}$ & $\begin{array}{c}\text { ReCiPe } \\
\text { Endpoints }\end{array}$ \\
\hline 1 & 0.00085 & 0.00091 \\
\hline 2 & 0.00085 & 0.00091 \\
\hline 3 & 0.00099 & 0.00105 \\
\hline 4 & 0.00099 & 0.00105 \\
\hline 5 & 0.00099 & 0.00105 \\
\hline 6 & 0.00095 & 0.00101 \\
\hline 7 & 0.00106 & 0.00112 \\
\hline 8 & 0.00102 & 0.00108 \\
\hline 9 & 0.00113 & 0.00121 \\
\hline
\end{tabular}

Cups number 3, 4 and 5, marked in yellow, show a 15\% difference in ReCiPe endpoint score between the upper tolerance PE coated board and the lower tolerance uncoated board outer cup wall. Either of the product economic inventory choices in the above table could have been chosen by the LCA operative. 


\subsubsection{The Inner Cup of the Double Wall 8oz Cup}

This subchapter will address the issues of DWC inner wall construction as could lead to variances in product economic inventory input to LCA.

The inner cup in a DWC is simply a single wall paper cup that has not been printed. This inner cup is inserted into the outer cup that has had glue applied to its inner surface.

Cup stock board also has a 3\% weight tolerance. Table 10.14 below exhibits this 3\% weight tolerance in the associated ReCiPe endpoints.

Table 10.14: 8oz DWC Inner Cup Wall

\begin{tabular}{c|c|c|c}
\hline \multirow{2}{*}{$\begin{array}{c}\text { Inner Cup } \\
\text { No. }\end{array}$} & $\begin{array}{c}\text { ReCiPe } \\
\text { Endpoints }\end{array}$ & $\begin{array}{c}\text { Lower } \\
\text { Tolerance }\end{array}$ & $\begin{array}{c}\text { Upper } \\
\text { Tolerance }\end{array}$ \\
\cline { 3 - 4 } & $\begin{array}{c}\text { ReCiPe } \\
\text { Endpoints }\end{array}$ & $\begin{array}{c}\text { ReCiPe } \\
\text { Endpoints }\end{array}$ \\
\hline 1 & 0.00188 & 0.00182 & 0.00194 \\
\hline 2 & 0.00188 & 0.00182 & 0.00194 \\
\hline 3 & 0.00221 & 0.00214 & 0.00228 \\
\hline 4 & 0.00221 & 0.00214 & 0.00228 \\
\hline 5 & 0.00221 & 0.00214 & 0.00228 \\
\hline 6 & 0.00209 & 0.00203 & 0.00215 \\
\hline 8 & 0.00232 & 0.00225 & 0.00239 \\
\hline 9 & 0.00220 & 0.00213 & 0.00227 \\
\hline & 0.00247 & 0.00240 & 0.00254 \\
\hline
\end{tabular}

\subsubsection{The Complete 8oz Double Wall Paper Cup and Lid}

This subchapter will address the issues of variances in materials and weights of all the components in a DWC and lid as could lead to variances in product economic inventory input to LCA.

In Table 10.15 below, the difference in DWC and lid, considering the outer cup wall material, and the extremes of tolerances and lid material type have been researched, and the figures are displayed in ReCiPe endpoints, with the difference between the lowest and highest figure being $10.34 \%$. These figures could have been derived from product inventory data chosen by the LCA operative. 
Table 10.15: DWC and Lid - Lower and Upper Tolerance Weights represented in ReCiPe Endpoints with both Lid Material Types and a PE coated and Uncoated Outer Cup Walls

\begin{tabular}{|c|c|c|c|c|c|c|c|c|}
\hline \multirow{3}{*}{$\begin{array}{c}\text { DWC } \\
\text { No. }\end{array}$} & Inner Cup & $\begin{array}{l}\text { Outer Cup } \\
\text { uncoated }\end{array}$ & Lids & \multirow{3}{*}{$\begin{array}{c}\text { Total } \\
\text { DWC and } \\
\text { Lid ReCiPe } \\
\text { Endpoints }\end{array}$} & Inner Cup & Outer Cup & Lids & \multirow{3}{*}{$\begin{array}{c}\text { Total } \\
\text { DWC and } \\
\text { Lid ReCiPe } \\
\text { Endpoints }\end{array}$} \\
\hline & \multirow{2}{*}{\begin{tabular}{|c}
$\begin{array}{c}\text { Lower } \\
\text { Tolerance }\end{array}$ \\
$\begin{array}{c}\text { ReCiPe } \\
\text { Endpoints }\end{array}$
\end{tabular}} & \multirow{2}{*}{\begin{tabular}{|c|}
$\begin{array}{c}\text { Lower } \\
\text { Tolerance }\end{array}$ \\
$\begin{array}{c}\text { ReCiPe } \\
\text { Endpoints }\end{array}$
\end{tabular}} & \multirow[t]{2}{*}{$\begin{array}{l}\text { Lower } \\
\text { Tolerance }\end{array}$} & & \multirow{2}{*}{\begin{tabular}{|c}
$\begin{array}{c}\text { Upper } \\
\text { Tolerance }\end{array}$ \\
$\begin{array}{c}\text { ReCiPe } \\
\text { Endpoints }\end{array}$
\end{tabular}} & \multirow{2}{*}{\begin{tabular}{|c|c|}
$\begin{array}{c}\text { Upper } \\
\text { Tolerance }\end{array}$ \\
$\begin{array}{c}\text { ReCiPe } \\
\text { Endpoints }\end{array}$
\end{tabular}} & \multirow[t]{2}{*}{$\begin{array}{c}\text { Upper } \\
\text { Tolerance }\end{array}$} & \\
\hline & & & & & & & & \\
\hline 1 & 0.00182 & 0.00085 & 0.000142 & 0.00282 & 0.001936 & 0.000989 & 0.000213 & 0.00314 \\
\hline 2 & 0.00182 & 0.00085 & 0.000142 & 0.00282 & 0.001936 & 0.000989 & 0.000213 & 0.00314 \\
\hline 3 & 0.00214 & 0.00099 & 0.000142 & 0.00328 & 0.002276 & 0.001164 & 0.000213 & 0.00365 \\
\hline 4 & 0.00214 & 0.00099 & 0.000142 & 0.00328 & 0.002276 & 0.001164 & 0.000213 & 0.00365 \\
\hline 5 & 0.00214 & 0.00099 & 0.000142 & 0.00328 & 0.002276 & 0.001164 & 0.000213 & 0.00365 \\
\hline 6 & 0.00203 & 0.00095 & 0.000142 & 0.00312 & 0.002153 & 0.001102 & 0.000213 & 0.00347 \\
\hline 7 & 0.00225 & 0.00106 & 0.000142 & 0.00345 & 0.002390 & 0.001226 & 0.000213 & 0.00383 \\
\hline 8 & 0.00213 & 0.00102 & 0.000142 & 0.00329 & 0.002266 & 0.001164 & 0.000213 & 0.00364 \\
\hline 9 & 0.00240 & 0.00113 & 0.000142 & 0.00367 & 0.002544 & 0.001298 & 0.000213 & 0.00405 \\
\hline
\end{tabular}

In Table 10.16 below, a comparison is made between the lower tolerance weights with no PE coating on the outer cup and a PP lid compared with the higher tolerance weights with PE coating on the outer cup and a HIPS lid. The comparative Star ratings incur a small change in this case.

Table 10.16: DWC and Lid - Comparison in Star Rating between the Lower and Upper Tolerance Weight with Difference in Materials Choices

Lower Tolerance PP lid and no-PE on outer cup Upper Tolerance HIPS lid and PE on outer cup

\begin{tabular}{c|c|c|c|c|c|c|c|c}
\hline $\begin{array}{c}\text { 8oz DWC } \\
\text { \& Lid No. }\end{array}$ & $\begin{array}{c}\text { ReCiPe } \\
\text { Endpoints }\end{array}$ & $\begin{array}{c}\text { Ratio to } \\
\text { the Mean }\end{array}$ & $\begin{array}{c}\text { Rank } \\
\text { Order }\end{array}$ & $\begin{array}{c}\text { Star } \\
\text { Rating }\end{array}$ & $\begin{array}{c}\text { ReCiPe } \\
\text { Endpoints }\end{array}$ & $\begin{array}{c}\text { Ratio to } \\
\text { the Mean }\end{array}$ & $\begin{array}{c}\text { Rank } \\
\text { Order }\end{array}$ & $\begin{array}{c}\text { Star } \\
\text { Rating }\end{array}$ \\
\hline 1 & 0.00282 & 0.87 & 1 & 4 & 0.00314 & 0.88 & 1 & 3.5 \\
\hline 2 & 0.00282 & 0.87 & 1 & 4 & 0.00314 & 0.88 & 1 & 3.5 \\
\hline 3 & 0.00328 & 1.02 & 4 & 2.5 & 0.00365 & 1.02 & 5 & 2.5 \\
\hline 4 & 0.00328 & 1.02 & 4 & 2.5 & 0.00365 & 1.02 & 5 & 2.5 \\
\hline 5 & 0.00328 & 1.02 & 4 & 2.5 & 0.00365 & 1.02 & 5 & 2.5 \\
\hline 6 & 0.00312 & 0.97 & 3 & 3 & 0.00347 & 0.97 & 3 & 3 \\
\hline 7 & 0.00345 & 1.07 & 8 & 2 & 0.00383 & 1.07 & 8 & 2 \\
\hline 8 & 0.00329 & 1.02 & 7 & 2.5 & 0.00364 & 1.02 & 4 & 2.5 \\
\hline 9 & 0.00367 & 1.14 & 9 & 1 & 0.00405 & 1.13 & 9 & 1 \\
\hline
\end{tabular}

It is questionable whether or not this is realistic, if an LCA operative is simply weighing the cup to derive the product inventory data and always assuming the same materials 
composition. The permutations in identified weight and materials is large; the above Table 10.16 only shows the extreme of the tolerance and materials choices and not all the potential combinations.

As an example, Table 10.17 below demonstrates the differences in comparative results if the upper (U) and lower (L) ReCiPe figures from Table 10.16 above were to be mixed, in this case every cup having alternatively the upper and then lower ReCiPe figure. The comparative Star ratings incur a more significant change when both upper and lower ReCiPe figures are used within the same study.

Table 10.17: The Effect of Mixed Lower and Upper ReCiPe Figures on the DWC and Lid Rating

Based on Upper and Lower ReCiPe Endpoints

Based on Lower and Upper ReCiPe Endpoints

\begin{tabular}{|c|c|c|c|c|c|c|c|c|c|c|}
\hline $\begin{array}{c}80 z \\
\text { DWC \& } \\
\text { Lid No. }\end{array}$ & & $\begin{array}{c}\mathrm{ReCiPe} \\
\text { Endpoints }\end{array}$ & $\begin{array}{l}\text { Ratio to } \\
\text { the Mean }\end{array}$ & $\begin{array}{l}\text { Rank } \\
\text { Order }\end{array}$ & $\begin{array}{c}\text { Star } \\
\text { Rating }\end{array}$ & & $\begin{array}{c}\mathrm{ReCiPe} \\
\text { Endpoints }\end{array}$ & $\begin{array}{l}\text { Ratio to } \\
\text { the Mean }\end{array}$ & $\begin{array}{l}\text { Rank } \\
\text { Order }\end{array}$ & $\begin{array}{c}\text { Star } \\
\text { Rating }\end{array}$ \\
\hline 1 & U & 0.00314 & 0.92 & 3 & 3.5 & $L$ & 0.00282 & 0.83 & 1 & 4 \\
\hline 2 & $L$ & 0.00282 & 0.82 & 1 & 4.5 & U & 0.00314 & 0.93 & 2 & 3 \\
\hline 3 & U & 0.00365 & 1.07 & 6 & 2 & L & 0.00328 & 0.97 & 3 & 3 \\
\hline 4 & $L$ & 0.00328 & 0.96 & 4 & 3 & U & 0.00365 & 1.08 & 8 & 1.5 \\
\hline 5 & U & 0.00365 & 1.07 & 6 & 2 & L & 0.00328 & 0.97 & 3 & 3 \\
\hline 6 & $L$ & 0.00312 & 0.91 & 2 & 3.5 & U & 0.00347 & 1.03 & 6 & 2 \\
\hline 7 & U & 0.00383 & 1.12 & 8 & 1.5 & L & 0.00345 & 1.02 & 5 & 2 \\
\hline 8 & $L$ & 0.00329 & 0.96 & 5 & 3 & U & 0.00364 & 1.08 & 7 & 1.5 \\
\hline 9 & U & 0.00405 & 1.18 & 9 & 1.5 & $L$ & 0.00367 & 1.09 & 9 & 1.5 \\
\hline
\end{tabular}

Questions could be asked if it would not be better to adopt a spread of product inventory values, but the dimension of this spread would need to be identified and suffer the same consequences as occur in making assumptions in the absence of stakeholder input. A potentially incorrect spread could render the position of a product within a comparative ECS equally as incorrect as for a single incorrect value. This effect could be particularly undesired in a high resolution category. 
In the above study of the outer and inner cups, no account has been made for the resultant skeletal waste derived from cutting their blanks from the board, as can be seen in Figure 10.9 below.

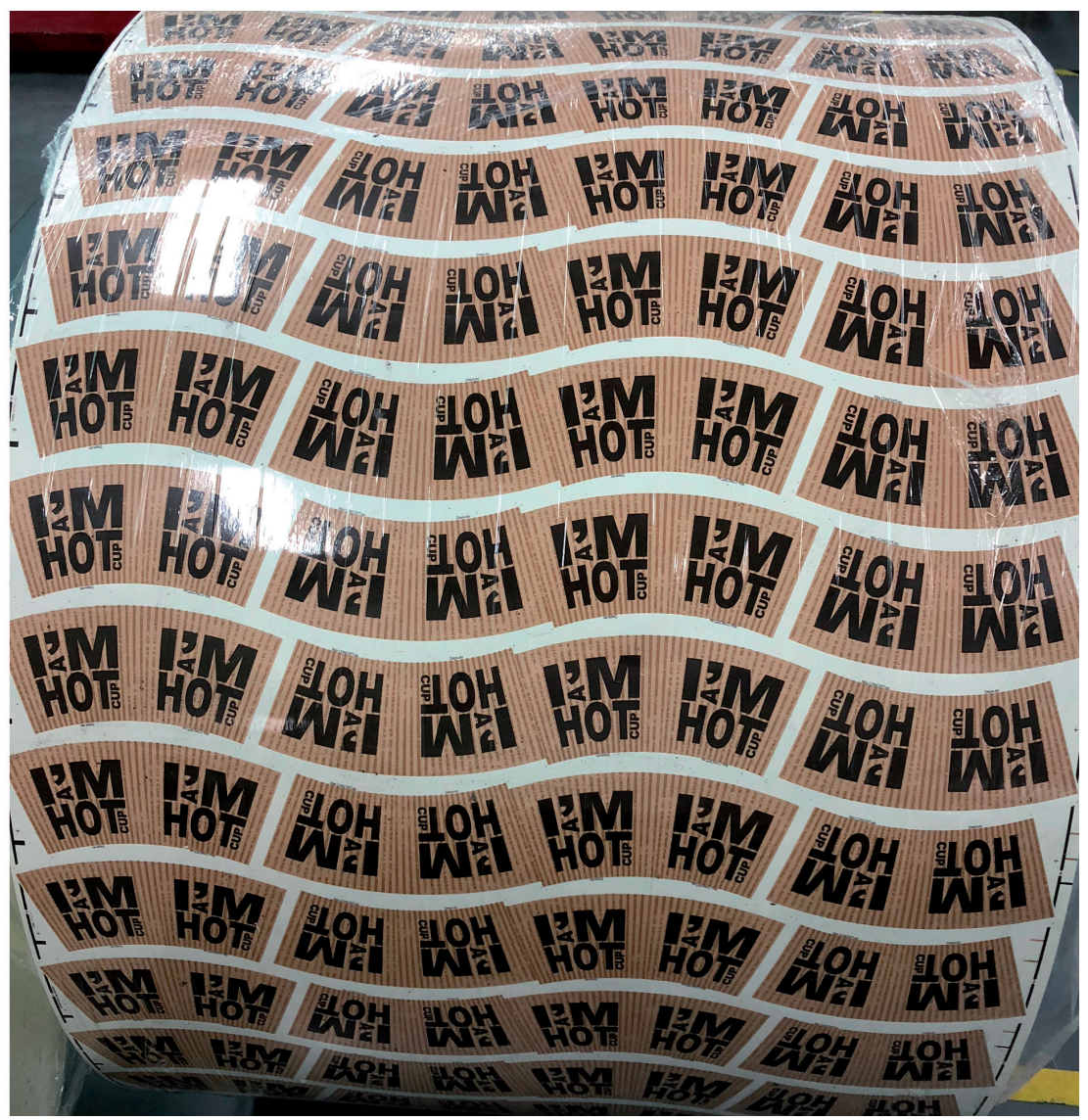

Figure 10.9: The Layout of Cup Blanks on the Board

This is unlikely to be an issue, as all the cups in the research category were double wall paper cups and would all be subject to similar skeletal waste levels. Where accounting for this skeletal waste becomes important is when cups of another material and/or process type are added to the category for comparison. Knowledge of the implication of sighted materials in terms of their associated processes would seem important when comparing FSD and making comparative ECS.

Simply taking a product, weighing it and then progressing with the traditional product economic inventory discovery may lead to incorrect conclusions as regards the relative position of a product within an ECS based on a comparative LCA study. 
Various approaches, regarding weight, could be taken as follows:

1. A single cup could be weighed, and this weight used in the comparative study.

2. An average weight of a larger quantity of cups, if available, could be used.

3. Having established the cup board specification and correlated that with the intended gsm and thickness specification from the cup board manufacturer, the operative could use this gsm figure to derive the intended cup weight.

The above three approaches could each produce a different weight related inventory and resultant position of the product within a comparative study. Product technical knowledge is important in establishing weight based inventory data.

\subsubsection{Further Examples of Materials Variance in Double Wall Paper Cup}

The cup stock board from which the cups are made is typically extrusion coated with PE. PLA coated cups are also now available. In Table 10.18 below, a PLA coated cup, number $5 a$, replaces cup number 5 in Table 10.17 above.

During the study of this $80 z$ category, it was identified that cup 5 a was of a design that had previously had "sugarcane" printed on it to indicate that the paper was made using sugarcane bagasse. The version being considered for the 6oz category had the same basic print style but with the "sugarcane" part of the ECS removed and replaced with "natural". The source of the cup was also unknown.

The incorrect use of paper liquid packaging board in the LCA input in place of board containing bagasse could likely lead to a misrepresentation of the cup within the category. The need to identify the board type in such a high resolution product category would appear important.

FTIR spectra of the board were collected and compared with other bagasse board product and common cup board. Spectra differences were identified that were different from the common cup board and these were compared to similar scientific studies (Mothé, $C$. G., et al., 2009), (Pavithra, R., et al., 2015) and (Singh, R., et al., 2005).

The board was identified as being sugarcane bagasse board. Experts confirmed that cups made using bagasse board were sourced from India. In this case, the FUMCO approach, supported by product technical knowledge, permitted the correct identification of the polymer coating, the cup board material and the $\mathrm{CoO}$ of the cup. Hence, it would appear important to ensure that the materials were correctly identified and quantified for all cups within the category. Product related technical and marketing knowledge had helped to identify the materials and $\mathrm{CoO}$ in this case. 
Table 10.18: 8oz Hot Beverage Cup in which the Same Cup is considered as PE coated and then PLA Coated

\begin{tabular}{c|c|c|c|c}
\hline $\begin{array}{c}\text { 8oz } \\
\text { DWC } \\
\text { No. }\end{array}$ & $\begin{array}{c}\text { ReCiPe } \\
\text { End- } \\
\text { points }\end{array}$ & $\begin{array}{c}\text { Ratio } \\
\text { to the } \\
\text { Mean }\end{array}$ & $\begin{array}{c}\text { Rank } \\
\text { Order }\end{array}$ & $\begin{array}{c}\text { Star } \\
\text { Rating }\end{array}$ \\
\hline 1 & 0.00188 & 0.87 & 1 & 4 \\
\hline 2 & 0.00188 & 0.87 & 1 & 4 \\
\hline 3 & 0.00221 & 1.02 & 5 & 2.5 \\
\hline 4 & 0.00221 & 1.02 & 5 & 2.5 \\
\hline 5 & 0.00221 & 1.02 & 5 & 2.5 \\
\hline 6 & 0.00209 & 0.97 & 3 & 3 \\
\hline 7 & 0.00232 & 1.07 & 8 & 2 \\
\hline 8 & 0.00220 & 1.02 & 4 & 2.5 \\
\hline 9 & 0.00247 & 1.14 & 9 & 1 \\
\hline
\end{tabular}

\begin{tabular}{c|c|c|c|c}
\hline $\begin{array}{c}\text { 8oz } \\
\text { DWC } \\
\text { No. }\end{array}$ & $\begin{array}{c}\text { ReCiPe } \\
\text { End- } \\
\text { points }\end{array}$ & $\begin{array}{c}\text { Ratio } \\
\text { to the } \\
\text { Mean }\end{array}$ & $\begin{array}{c}\text { Rank } \\
\text { Order }\end{array}$ & $\begin{array}{c}\text { Star } \\
\text { Rating }\end{array}$ \\
\hline 1 & 0.00188 & 0.85 & 1 & 4 \\
\hline 2 & 0.00188 & 0.85 & 1 & 4 \\
\hline 3 & 0.00221 & 1.00 & 5 & 2.5 \\
\hline 4 & 0.00221 & 1.00 & 5 & 2.5 \\
\hline $5 a$ & 0.00262 & 1.19 & 9 & 0.5 \\
\hline 6 & 0.00209 & 0.95 & 3 & 3 \\
\hline 7 & 0.00232 & 1.05 & 7 & 2 \\
\hline 8 & 0.00220 & 1.00 & 4 & 2.5 \\
\hline 9 & 0.00247 & 1.12 & 8 & 1.5 \\
\hline
\end{tabular}

The Star rating of cup 5 and $5 a$, marked in yellow in above Table 10.18, has changed by two Stars, the ReCiPe endpoint value of the PLA coated cup, 5a, compared to the PE coated cup, 5 , is $15.65 \%$ higher. Depending on the mix of other cup ReCiPe values within the compared category, this increase due to PLA in place of PE could be more or less significant than the above Star rating change.

Cup stock boards are subject to $3 \%$ tolerance in weight which should be considered in the above calculations. Product weight is a critical factor in calculating the eventual environmental impact of a product, as it influences many factors within a product life cycle.

In Table 10.19 below, examples of some of the potential differences in material inventory, as relates to a study of paper cups, are listed.

Table 10.19: Examples of Common Paper Cup Material Inventory Differences

\begin{tabular}{l|c|c|c}
\hline \multicolumn{1}{l}{ Inventory } & \multicolumn{3}{c}{ Materials Inventory Differences } \\
\hline Board Type & LPB & SBB & Kraft Paper \\
\hline Polymer Type & PE & PLA & no mention \\
\hline Cup Weight & 1 sample & average & surface area \\
\hline Process Waste & O\% & $10 \%$ & $27 \%$ \\
\hline Sealing & Glue & Heat & - \\
\hline Polymer Layers & 0 & 1 & 2 \\
\hline Lid Material & HIPS & PP & - \\
\hline Lid Weight & 1 sample & average & - \\
\hline
\end{tabular}




\subsubsection{Conclusions - Double Wall Paper Cup}

The study of a DWC and lid is presented to show the cumulative effects of poor or incorrect economic inventory choices and the potential benefit of technologically relevant knowledge as regards the product type.

Technical knowledge of paper cups may produce a very different result in an LCA based comparative cup study compared to the same study carried out by an LCA generalist. The value of this knowledge would appear to be of even greater importance in high resolution product categories.

\subsection{Market Knowledge}

In Figure 10.10 below, the stages in which market knowledge is required is highlighted.

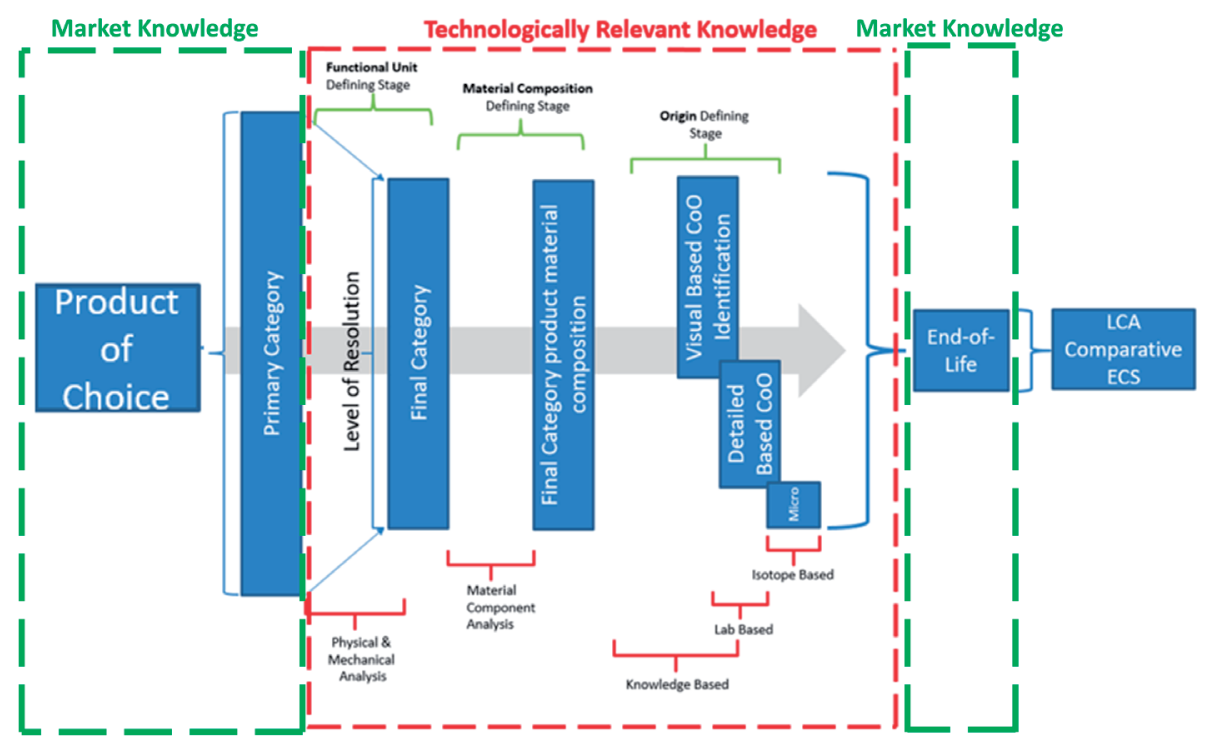

Figure 10.10: Market Knowledge required for Comparative ECS

Product comparative ECS are used for marketing purposes, with marketers being the party that are likely to initiate the development of an ECS. Their role in developing the ECS, and setting its goal, is considered. 
Market knowledge would be required for the following:

1. defining the product of choice for which to form a comparative ECS

2. defining the primary category definition to defend membership choices from a market representativeness perspective

3. defining the final market of the comparative ECS in order to identify the relevant endof-life scenario

In Chapter 7.3.2, reference is made to the effect of the relative position of an item within a comparative ECS due to market type based choices. As an example, plates could first be studied as a full category and then divided into their associated Retail and Food Service market category.

It could be said that market based choices are defendable through market audits and market based data.

The product configuration of a national market may differ from that of an export market, adding additional effort and cost to the export of a comparative ECS based product offering.

End-of-life scenario choices would be linked to the actual end-of-life scenario of the chosen market. This information is available but does change over time as recycling rates change. Regional differences in end-of-life scenarios may make the comparative ECS relevant in only one country, making the ECS irrelevant in another country, potentially adding additional cost to product export efforts if specific ECS have to be made for each export market.

A conclusion from an export perspective may be that a comparative ECS would need to be reformulated for each export market. The formulation of a comparative ECS for the total EU market may contain products that do not sell within a specific national market and may hence be irrelevant.

Changes in FS may also occur across different national markets. Different portion size and food type may require different PFR in different national markets.

It would be the marketer who would identify changes to product category configuration within a market, with some products leaving the market while new ones, of different inventory composition, enter the market. They may also be the party that would initiate an update of such comparative studies, due to changes in the products within a market. 


\subsection{The Claim Maker}

If the claim maker is the packaging supplier, as they are the party with the detailed knowledge of packaging (Van Sluisveld, M.A.E., et al., 2013), it could be questioned if their knowledge would be sufficient to identify all potential materials, processes and sources across a product category and if they are the party best suited to establishing the most objective comparative ECS.

A packaging supplier could be a:

1. manufacturer

2. trader

Traders can choose the country of origin of their products; a manufacturer is dependent on local available energy sources. A manufacturer typically relies on specific materials or processes whereas a trader can choose from all products of all materials and processes available to them.

"LCA practitioners are often generalists and should delegate an elaboration of indicators plus quantification to specialists" (Klöpffer, W., et al., 2014). It could be practical for the claim maker or LCA operative to be a specialist in the field of packaging technology and FSD.

Concern as to who the claim maker is, in terms of their potential bias, is therefore a consideration. If the claim maker is also the owner of the laboratory identifying the various LCA inputs, questions could be asked as to their results and the type of controls required to make sure they are unbiased.

It could be concluded that the claim maker would ideally need to be an unbiased party with the relevant product and technological knowledge.

\subsection{Chapter 10 Conclusions}

While the FUMCO operational model may aid in developing and supporting a comparative ECS, it is evident that relevant product and technological knowledge is required. It is identified that the lack of knowledge leading to wrong choices, omissions or technologically incorrect assumptions can influence the relative position of a product within a comparative ECS of FSD. Issues of linguistics, jargon and semantics may also further affect choices and contribute to product misrepresentation.

In response to research question $2 \mathrm{~d}$, technologically relevant knowledge is a significant factor in claims such as PEF and EPD. It is evident that the LCA operative making a comparative ECS for FSD would require to at least have knowledge of the following as 
relates specifically to FSD, these being the topics identified in the research. However, there may be more; this list serves as an example to affirm the assumption that relevant knowledge is required.

1. Testing based on Functional Specification

2. Material Component Analysis

3. Materials Processing

4. Origin Knowledge and Origin Analysis

5. Packaging Technology

6. Life Cycle Assessment

7. FSD Market

The lack of relevant knowledge could lead to incorrect product choices in support of policy decisions.

Based on the importance of this knowledge and the risk of wrong choices, omissions or technologically incorrect assumptions, it could be questioned if LCA generalists would be a reliable study party for comparative ECS for FSD. This may indicate that LCA operatives should be product specialists that need to relevantly source, interpret and apply all the appropriate data.

Chapters 6 to 10 constitute Part 2 of the study (Studying the factors to be addressed in developing a method). A conclusion related to the research in Part 2 will follow. 


\section{Review of Conclusions from Part 2}

As described in Chapter 1.5, the study is divided into three stages, with Part 2 defined as:

Part 2 - Studying the factors to be addressed in developing a method.

The method mentioned in the above research question is derived from the central research question of the study which is defined as:

CRQ: Is it possible to develop a method to optimize the quality of LCA product economic inventory input, in support of product LCA based comparative claims, in the presence and absence of stakeholder cooperation?

In accordance with RQ 1a, Part 1 identified factors that need to be addressed regarding any potential method; Part 2 then researched approaches to addressing these factors.

The approach described in Part 2 with regard to the LCA input is referred to as FUMCO.

Conclusions from the research in Part 2 were:

1. The extent to which a product category must be defined for a comparative ECS would appear to require to be very exact. ISO 14025:2006 states that "the function, technical performance and use of comparative products must be identical".

It could be said that the exact definition of a FU may have to be developed based on product testing as well as general product FS. The exact FS of the product requires defining and its qualification for inclusion in the category might require significant testing. Any changes in the definition of the category or product specification or functionality may lead to very different results as regards the positioning of a product within a comparative ECS. It can be questioned at what point the generic functionality of a product is acceptable to a category definition in which products with additional functionality exist.

Through the use of physical and mechanical testing instrumentation, to name but a few, it is possible to quantify a FS of a product. Quantitatively identifying compliance to a PFR permits an objective defence of the compliance of a product.

2. The EU Product Environmental Footprint or PEF states that all resources should be included in a study, stating that it is "important to express data in terms of constituent substances". It further states that materials should be disaggregated and classified according to their constituent fractions, as these may contribute to different environmental impact categories. 
Research shows that materials analysis contributes to increasing the potential accuracy of a comparative ECS and that materials analysis could be facilitated by the use of analytical laboratory instrumentation. Identification of material components within a product do not only account for the material but also its associated manufacturing processes, transport and end-of-life implications. This may influence the scope of the study and could alter the order in which LCA studies are carried out, from "goal, scope, inventory" to "goal, inventory, scope".

3. The choices of $\mathrm{CoO}$ of a product can significantly affect the positioning of a product within an ECS. Both Initial visual level expertise from experienced FSD purchasers and a Detailed level analytical instrument based study of the component parts within a FSD, against an appropriate library, may help to reduce uncertainty with regard to identifying the $\mathrm{CoO}$ of a product as regards LCA input for a comparative ECS study. A variety of potential approaches to identifying the $\mathrm{CoO}$ were researched; these are not exhaustive but were examples of techniques that may potentially aid in identifying the $\mathrm{CoO}$ of an FSD.

4. While the FUMCO operational model may aid in developing and supporting a comparative ECS, it is evident that relevant product and technological knowledge is required. It is identified that the lack of knowledge, even on a detailed level, leading to wrong choices, omissions or technologically incorrect assumptions can influence the relative position of a product within a comparative ECS of FSD. Due to the lack of this knowledge, a product risks misrepresentation.

An LCA operative with relevant product and technological knowledge, applying FUMCO in a study to develop an LCA based comparative ECS, may produce different product economic inventory data than from those based on the current inventory collection approaches, with general, rather than product related, knowledge of the products in a category, potentially leading to a difference in relative outcome for a product within a comparative ECS. This FUMCO based outcome may be more accurate than if the current approach to product economic inventory collection had been adopted.

It would appear evident that the maximum chance of correct product inventory LCA input data is required if products are to be compared, especially if the results of this comparison are to influence consumer choice or government policy. Accuracy matters, not just for an existing study but for future studies in which product economic inventory data is taken forward from the existing study, given that current inventory collection approaches rely heavily on previous studies.

The use of operatives with technologically relevant knowledge, taking a FUMCO approach, may increase the chance that products within a comparative ECS are better represented.

In Part 3 of this study, FUMCO will be further tested, a sensitivity study and LCA expert critique of the approach will be made and a final conclusion drawn. 


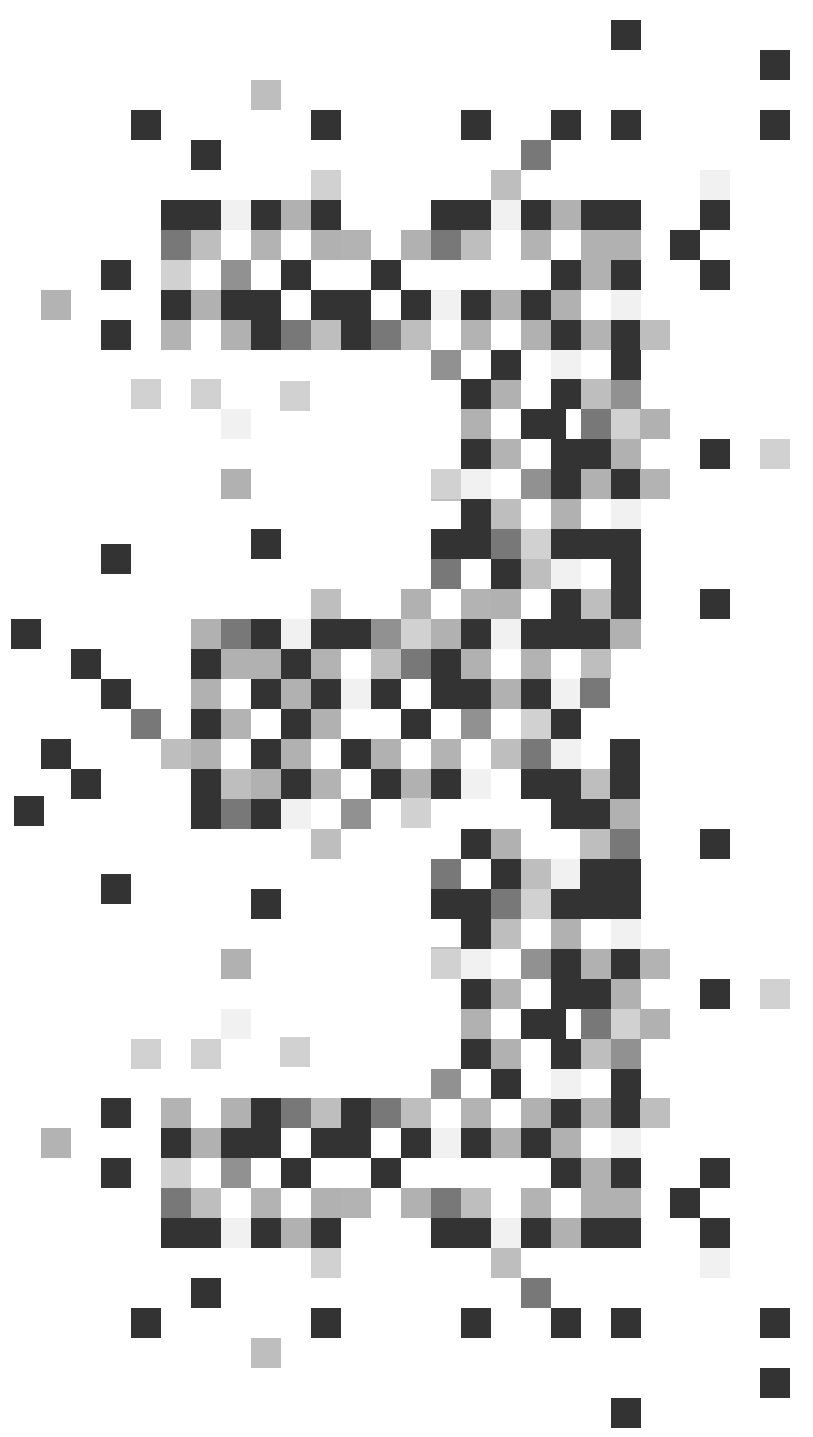




\section{Chapter 11}

\section{Testing FUMCO across a Range of Food Service Disposables}


In this chapter, the FUMCO approach is tested, as follows:

Test No.1 - A range of Disposable Plastic Drinking Glasses for cold beverages will be used to test each part of the FUMCO method, notably the:

a. Functional Unit (FU) and its associated Functional Specification (FS)

b. Material Composition (MC)

c. Country of Origin ( $\mathrm{CoO})$

d. Requirement for Technologically Relevant Knowledge regarding the product

Hence, each part is tested against the same product type.

Test No.2 - Three different FSD types will be used, each to test parts a) to c) of the four parts of the FUMCO method as stated above, while Technologically Relevant Knowledge as relates to these three tests will be addressed.

Hence, each of parts a) to c) are tested against a different product type.

The chosen categories, cold beverage drinking glasses as well as a range of diverse FSD categories, differ as regards the type of products they include. The first category of cold beverage plastic drinking glasses consists of fairly similar products, while the second category of FSD differ significantly in their product design, materials and process complexity.

The objective is to seek to prove that FUMCO can make a contribution to the accuracy and objectivity of product economic inventory data, as defined in Chapter 3.3, for a wide variety of FSD category types, with the data to be input to a comparative LCA study in the absence of the product stakeholders.

This chapter is part of Stage 3 (Testing, evaluation, discussion and conclusion), involving further research to establish the first part of $\mathrm{RQ} 3 \mathrm{a}$ as follows:

$R Q$ 3a. To what extent does the use of a potential identified method for LCA input derive a different result from a simply visual based method or other common inventory identification methods; what are the sensitivities of the method? 


\subsection{Introduction}

The test will research the relative position of a product within a category based on studies into the functional unit (FU) and functional specification (FS), and will study the material composition (MC), country of origin (CoO), and the effects of lack of product and technologically relevant knowledge.

The specific hypothesis that will be tested is:

If FUMCO could aid in establishing greater objectivity in deriving a balanced score between FSD in a comparative ECS in the absence of stakeholder input:

1. the choice of category can influence the relative position of an FSD ranking and rating

2. the material composition can influence the relative position of an FSD ranking and rating

3. the country of origin can influence the relative position of an FSD ranking and rating

4. knowledge and insight are required in order to include the correct processes because these can influence the relative position of an FSD ranking and rating

The tests are based on articles purchased from retailers and wholesalers as well as those being used by Food Service operators. The product collection and preparation were initiated as per the approach described in Subchapter 7.3. The tests and analysis applied are those described in Chapters 7, 8 and 9 . The rating and ranking of the products follow the methods as described in Chapter 6, based on endpoint values from the ReCiPe methodology.

\subsection{Test No.1 - Disposable Plastic Beverage Drinking Glasses for Cold Drinks}

On 24th August 2014, samples of disposable transparent plastic drinking glasses ('glasses') of the type used to hold cold beverages were collected from the Dutch market. The total range of these collected sample glasses is listed below in Table 11.1.

The range of glasses in Table 11.1 are labelled as GLASS-01 to GLASS-073. The range covers 71 glasses, as GLASS-08 and GLASS-56 were not present in the sample range. This means that the worst glass in the rank order is ranked 71 st.

The list below includes tampon-printed logo glasses and unprinted glasses. The glasses contain a spread of capacities from $200 \mathrm{ml}$ to $400 \mathrm{ml}$. Details related to this range of glasses can be found in Appendix K.

A 20\% bandwidth was used for the Star Rating in this case. 
Table 11.1: The Total Range of Collected Disposable Glasses

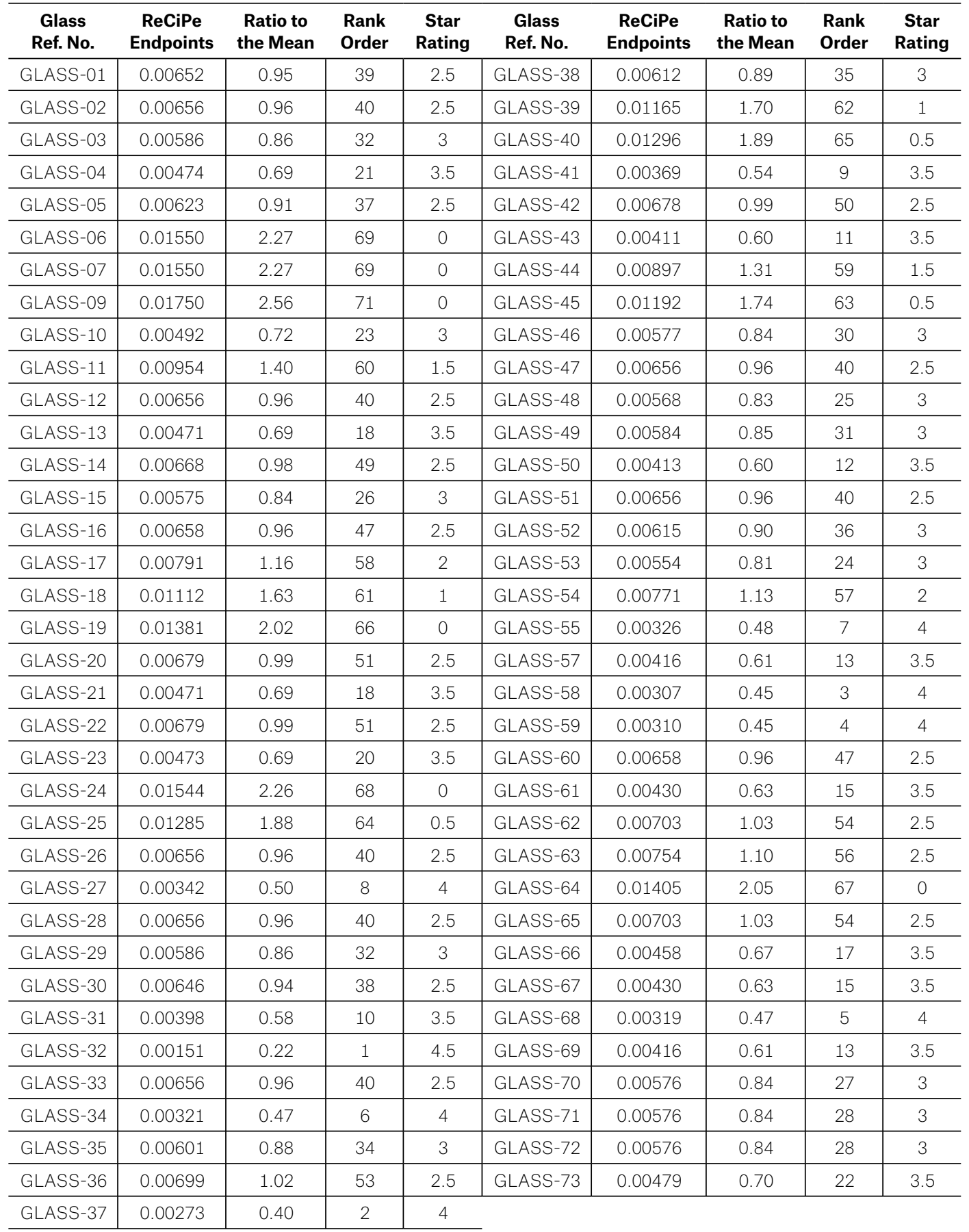




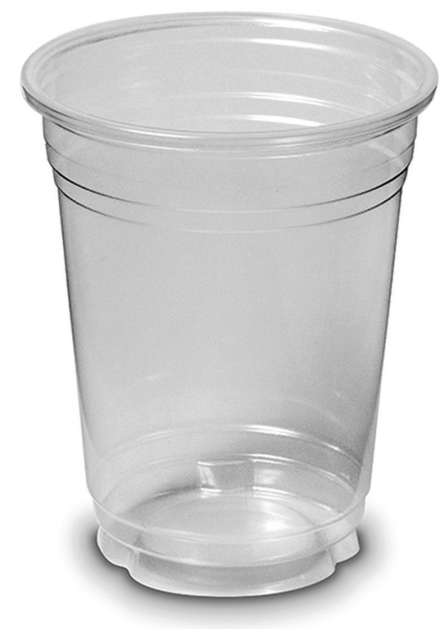

Figure 11.1: Example of a Disposable Cold Beverage Glass

\subsubsection{Cold Beverage Glasses - Functional Unit}

The above glasses were collected, based on a Functional Specification (FS) definition of a single disposable transparent cold beverage glass of the type designed to consume a single serving of beer or lemonade, with or without tampon-printed logos. All of the above glasses meet this FS, the FU in this case being one glass with this FS. This could be said to be a very general or wide FU definition, an overarching generic functionality as described in Chapter 7.

"What level of resolution is necessary to capture the desired effect?" (Ingwersen, W.W., et al., 2012). The first question that arises is if it is possible that the above FU is too general for the requirements of the claim maker who may wish to refer to a specific amount of beverage and/or a specific quality of glass.

For example, a very thin glass that is easy to crush may not be desired by a brewer as the best way to serve their chosen amount of beer. Alternatively, a party dispensing water may not have this same concern.

The glasses have a spread of fill capacities from $200 \mathrm{ml}$ to $400 \mathrm{ml}$. The glasses collected typically had $250 \mathrm{ml}$ and $300 \mathrm{ml}$ capacity printed on their outer packaging, when such packaging was available.

The above glasses were divided into two categories, each to cover popular serving amounts of cold beverage, notably $250 \mathrm{ml}$ and $300 \mathrm{ml}$. Each glass was placed on a weighing scale, which was then set to zero grams, and distilled water was poured into the glass up to the rim. 
Cups with a rim fill of 275 to $325 \mathrm{ml}$ were placed in category $A$ and those with a rim fill of 225 to $275 \mathrm{ml}$ were placed in category B. All remaining cups were considered outliers.

A third category, category C, can be seen in Table 11.2 below. This relates to all glasses with fill capacities of below $225 \mathrm{ml}$ and above $325 \mathrm{ml}$. While these glasses act as outliers to categories A and B, they could be taken into further comparative studies related to their lower or higher capacity categories.

This choice of a spread of $25 \mathrm{ml}$ around the $250 \mathrm{ml}$ and $300 \mathrm{ml}$ capacity category definition is partially subjective and serves as example to define a FS. It could also be derived from the large number of cups in a spread covering $280 \mathrm{ml}$ to $320 \mathrm{ml}$ (category A) and $230 \mathrm{ml}$ to $270 \mathrm{ml}$ (category B), indicating that these were the capacity categories to which the glass manufacturers were targeting their product.

The results of this categorization can be seen below in Table 11.2. 
Table 11.2: Categorization by Glass Capacity

\begin{tabular}{|c|c|c|c|c|c|c|c|c|}
\hline Category & $\begin{array}{l}\text { Glass Ref. } \\
\text { No. }\end{array}$ & $\begin{array}{c}\text { Capacity } \\
\mathrm{ml}\end{array}$ & Category & $\begin{array}{c}\text { Glass Ref. } \\
\text { No. }\end{array}$ & $\begin{array}{c}\text { Capacity } \\
\mathrm{ml}\end{array}$ & Category & $\begin{array}{c}\text { Glass Ref. } \\
\text { No. }\end{array}$ & $\begin{array}{c}\text { Capacity } \\
\text { ml }\end{array}$ \\
\hline \multicolumn{3}{|c|}{$300 \mathrm{ml}+/-25 \mathrm{ml}$} & \multicolumn{3}{|c|}{$250 \mathrm{ml}+/-25 \mathrm{ml}$} & \multicolumn{3}{|c|}{$\begin{array}{l}\text { Outliers below } 225 \mathrm{ml} \\
\text { and above } 325 \mathrm{ml}\end{array}$} \\
\hline A & GLASS-01 & 300 & B & GLASS-04 & 240 & C & GLASS-03 & 220 \\
\hline A & GLASS-02 & 300 & B & GLASS-05 & 250 & C & GLASS-11 & 210 \\
\hline A & GLASS-09 & 290 & B & GLASS-06 & 230 & C & GLASS-18 & 420 \\
\hline A & GLASS-12 & 300 & B & GLASS-07 & 230 & C & GLASS-19 & 520 \\
\hline A & GLASS-14 & 320 & B & GLASS-10 & 260 & C & GLASS-21 & 240 \\
\hline A & GLASS-16 & 290 & B & GLASS-13 & 240 & C & GLASS-24 & 500 \\
\hline$A$ & GLASS-17 & 290 & $B$ & GLASS-15 & 240 & C & GLASS-25 & 390 \\
\hline A & GLASS-20 & 320 & $B$ & GLASS-23 & 230 & C & GLASS-29 & 220 \\
\hline A & GLASS-22 & 320 & B & GLASS-27 & 230 & C & GLASS-36 & 440 \\
\hline A & GLASS-26 & 310 & B & GLASS-31 & 230 & C & GLASS-39 & 540 \\
\hline A & GLASS-28 & 310 & $B$ & GLASS-32 & 230 & C & GLASS-40 & 670 \\
\hline A & GLASS-30 & 310 & $B$ & GLASS-34 & 260 & $C$ & GLASS-41 & 180 \\
\hline A & GLASS-33 & 300 & B & GLASS-35 & 270 & C & GLASS-42 & 200 \\
\hline A & GLASS-45 & 310 & B & GLASS-37 & 230 & C & GLASS-53 & 370 \\
\hline A & GLASS-47 & 310 & B & GLASS-38 & 260 & C & GLASS-54 & 360 \\
\hline A & GLASS-50 & 300 & B & GLASS-43 & 250 & C & GLASS-55 & 330 \\
\hline A & GLASS-51 & 310 & $B$ & GLASS-44 & 250 & C & GLASS-61 & 345 \\
\hline A & GLASS-52 & 300 & B & GLASS-46 & 230 & C & GLASS-62 & 495 \\
\hline A & GLASS-57 & 300 & B & GLASS-48 & 230 & C & GLASS-63 & 600 \\
\hline$A$ & GLASS-58 & 280 & $B$ & GLASS-49 & 230 & C & GLASS-64 & 600 \\
\hline$A$ & GLASS-59 & 280 & $B$ & GLASS-73 & 230 & C & GLASS-65 & 495 \\
\hline A & GLASS-60 & 300 & & & & C & GLASS-66 & 340 \\
\hline$A$ & GLASS-68 & 300 & & & & $\mathrm{C}$ & GLASS-67 & 345 \\
\hline A & GLASS-69 & 300 & & & & & & \\
\hline A & GLASS-70 & 300 & & & & & & \\
\hline A & GLASS-71 & 300 & & & & & & \\
\hline A & GLASS-72 & 300 & & & & & & \\
\hline
\end{tabular}

Assuming the claim maker wants to make a claim regarding the category B glasses, the relative position of each glass can be seen below in Table 11.3. 
Table 11.3: The Relative Position of the Category B Glasses

\begin{tabular}{|c|c|c|c|c|c|}
\hline Category & Glass Ref.No. & $\begin{array}{c}\text { ReCiPe } \\
\text { Endpoints }\end{array}$ & $\begin{array}{c}\text { Ratio to the } \\
\text { Mean }\end{array}$ & $\begin{array}{l}\text { Rank } \\
\text { Order }\end{array}$ & $\begin{array}{c}\text { Star } \\
\text { Rating }\end{array}$ \\
\hline B & GLASS-04 & 0.00474 & 0.80 & 9 & 3 \\
\hline B & GLASS-05 & 0.00623 & 1.05 & 18 & 2.5 \\
\hline $\mathrm{B}$ & GLASS-06 & 0.01550 & 2.62 & 20 & 0 \\
\hline B & GLASS-07 & 0.01550 & 2.62 & 21 & 0 \\
\hline$B$ & GLASS-10 & 0.00492 & 0.83 & 11 & 3 \\
\hline $\mathrm{B}$ & GLASS-13 & 0.00471 & 0.80 & 7 & 3 \\
\hline B & GLASS-15 & 0.00575 & 0.97 & 13 & 2.5 \\
\hline B & GLASS-23 & 0.00473 & 0.80 & 8 & 3 \\
\hline $\mathrm{B}$ & GLASS-27 & 0.00342 & 0.58 & 4 & 3.5 \\
\hline $\mathrm{B}$ & GLASS-31 & 0.00398 & 0.67 & 5 & 3.5 \\
\hline $\mathrm{B}$ & GLASS-32 & 0.00151 & 0.26 & 1 & 4.5 \\
\hline$B$ & GLASS-34 & 0.00321 & 0.54 & 3 & 3.5 \\
\hline B & GLASS-35 & 0.00601 & 1.02 & 16 & 2.5 \\
\hline B & GLASS-37 & 0.00273 & 0.46 & 2 & 4 \\
\hline $\mathrm{B}$ & GLASS-38 & 0.00612 & 1.03 & 17 & 2.5 \\
\hline B & GLASS-43 & 0.00411 & 0.69 & 6 & 3.5 \\
\hline $\mathrm{B}$ & GLASS-44 & 0.00897 & 1.52 & 19 & 1 \\
\hline B & GLASS-46 & 0.00577 & 0.97 & 14 & 2.5 \\
\hline$B$ & GLASS-48 & 0.00568 & 0.96 & 12 & 2.5 \\
\hline $\mathrm{B}$ & GLASS-49 & 0.00584 & 0.99 & 15 & 2.5 \\
\hline $\mathrm{B}$ & GLASS-73 & 0.00479 & 0.81 & 10 & 3 \\
\hline
\end{tabular}

In comparison with the Star Rating for the total collected category of glasses, the category B glasses have undergone 13 changes in their Star Rating, marked above in the yellow cells.

Some glasses may be fragile and prone to crushing when in use. This may be acceptable when drinking cold beverages, such as water, but could be seen as unacceptable when serving beverages of high economic value, such as beer. The brewer may feel that this type of crushable, often lighter weight glass is not acceptable to the image or marketing of their beer.

This may lead to the withdrawal of this type of cup based on its ability to crush. This would require a specific FS that clearly defines the pressure applied to the walls of the cup at a certain displacement against certain defined test criteria. Testing of this type could be carried out using the Cup Wall Stiffness Tester shown in Figure 7.5. 


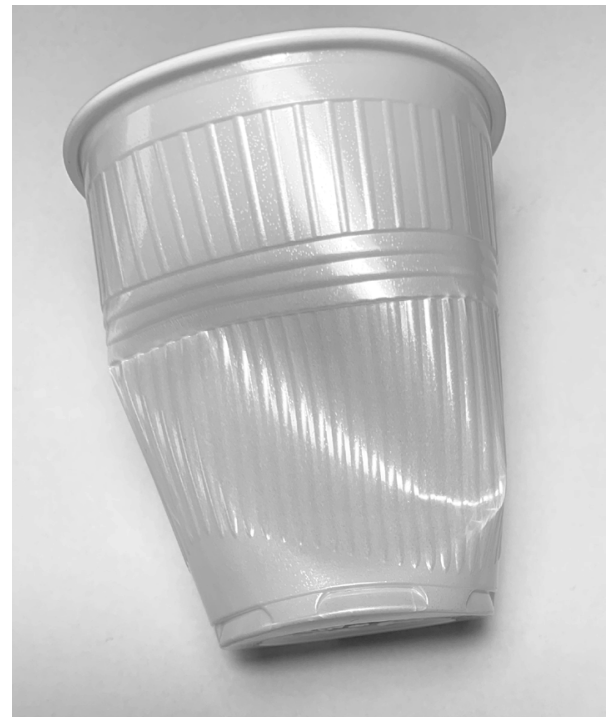

Figure 11.2: Typical Crushing that can occur in Disposable Cups and Glasses

Cup Wall Stiffness Tests were carried out, leading to the exclusion of glass numbers 32 and 37. Both of these cups are of a very low quality of the type more suited for use with an office water fountain.

While most of the glasses in category B are soft, with no hard edges or splinters, and would not be considered as dangerous with regard to flesh wounds or weaponization, there are cups that are potentially more dangerous. Concern of this type may be important at large outdoor events.

Cups that can splinter leaving hard sharp edges are those injection moulded glasses made of GPPS. These types of glasses, while meeting the general FS, may be non-compliant to a high resolution category considering personal safety. Identifying the injection moulded GPPS glasses is then required, these being glass numbers 6, 7 and 44. Testing for cups of a splinterable type could be carried out using the Cup Wall Stiffness Tester shown in Figure 7.5 .

Should the crushable and hard splinterable glasses be removed from category $B$, the relative position of the glasses further changes, as can be seen in the yellow cells in Table 11.4 below. 
Table 11.4: Category B with Crushable and Splinterable Glasses Removed

\begin{tabular}{|c|c|c|c|c|c|}
\hline Category & Glass Ref.No. & $\begin{array}{c}\mathrm{ReCiPe} \\
\text { Endpoints }\end{array}$ & $\begin{array}{l}\text { Ratio to the } \\
\text { Mean }\end{array}$ & Rank Order & Star Rating \\
\hline $\mathrm{B}$ & GLASS-04 & 0.00474 & 0.95 & 7 & 2.5 \\
\hline $\mathrm{B}$ & GLASS-05 & 0.00623 & 1.25 & 16 & 2 \\
\hline $\mathrm{B}$ & GLASS-10 & 0.00492 & 0.98 & 9 & 2.5 \\
\hline $\mathrm{B}$ & GLASS-13 & 0.00471 & 0.94 & 5 & 2.5 \\
\hline $\mathrm{B}$ & GLASS-15 & 0.00575 & 1.15 & 11 & 2 \\
\hline B & GLASS-23 & 0.00473 & 0.95 & 6 & 2.5 \\
\hline B & GLASS-27 & 0.00342 & 0.68 & 2 & 3.5 \\
\hline $\mathrm{B}$ & GLASS-31 & 0.00398 & 0.80 & 3 & 3 \\
\hline $\mathrm{B}$ & GLASS-34 & 0.00321 & 0.64 & 1 & 3.5 \\
\hline $\mathrm{B}$ & GLASS-35 & 0.00601 & 1.20 & 14 & 2 \\
\hline $\mathrm{B}$ & GLASS-38 & 0.00612 & 1.22 & 15 & 2 \\
\hline $\mathrm{B}$ & GLASS-43 & 0.00411 & 0.82 & 4 & 3 \\
\hline $\mathrm{B}$ & GLASS-46 & 0.00577 & 1.15 & 12 & 2 \\
\hline $\mathrm{B}$ & GLASS-48 & 0.00568 & 1.13 & 10 & 2 \\
\hline $\mathrm{B}$ & GLASS-49 & 0.00584 & 1.17 & 13 & 2 \\
\hline $\mathrm{B}$ & GLASS-73 & 0.00479 & 0.96 & 8 & 2.5 \\
\hline
\end{tabular}

In comparison with the Star Rating for the total category $B$, the glasses in this category $\mathrm{B}$, with crushable and splinterable glasses removed, have undergone 14 changes in their Star Rating.

It could also be possible that the category undergoes further changes to its resolution in the event that the brewer wanted a logo printed on their glass and only certain identified glass manufacturers within category B offered this option, or that the brewer wanted to adopt a specific end-of-life scenario for their beer glass offering, such as recycling, which would require compliance to a certain material type. In these cases, further knowledge and materials analysis may be required.

Assuming the claim maker wants to make a claim regarding the category A glasses, the relative position of each glass can be seen below in Table 11.5. 
Table 11.5: The Relative Position of the Category A Glasses

\begin{tabular}{|c|c|c|c|c|c|}
\hline Category & Glass Ref.No. & $\begin{array}{c}\mathrm{ReCiPe} \\
\text { Endpoints }\end{array}$ & $\begin{array}{l}\text { Ratio to the } \\
\text { Mean }\end{array}$ & Rank Order & Star Rating \\
\hline A & GLASS-01 & 0.00652 & 1.01 & 12 & 2.5 \\
\hline A & GLASS-02 & 0.00656 & 1.01 & 13 & 2.5 \\
\hline A & GLASS-09 & 0.01750 & 2.70 & 27 & 0 \\
\hline A & GLASS-12 & 0.00656 & 1.01 & 13 & 2.5 \\
\hline A & GLASS-14 & 0.00668 & 1.03 & 22 & 2.5 \\
\hline A & GLASS-16 & 0.00658 & 1.02 & 20 & 2.5 \\
\hline A & GLASS-17 & 0.00791 & 1.22 & 25 & 2 \\
\hline A & GLASS-20 & 0.00679 & 1.05 & 23 & 2.5 \\
\hline A & GLASS-22 & 0.00679 & 1.05 & 23 & 2.5 \\
\hline A & GLASS-26 & 0.00656 & 1.01 & 13 & 2.5 \\
\hline A & GLASS-28 & 0.00656 & 1.01 & 13 & 2.5 \\
\hline A & GLASS-30 & 0.00646 & 1.00 & 11 & 2.5 \\
\hline A & GLASS-33 & 0.00656 & 1.01 & 13 & 2.5 \\
\hline A & GLASS-45 & 0.01192 & 1.84 & 26 & 0.5 \\
\hline A & GLASS-47 & 0.00656 & 1.01 & 13 & 2.5 \\
\hline A & GLASS-50 & 0.00413 & 0.64 & 4 & 3.5 \\
\hline A & GLASS-51 & 0.00656 & 1.01 & 13 & 2.5 \\
\hline A & GLASS-52 & 0.00615 & 0.95 & 10 & 2.5 \\
\hline A & GLASS-57 & 0.00416 & 0.64 & 5 & 3.5 \\
\hline A & GLASS-58 & 0.00307 & 0.47 & 1 & 4 \\
\hline A & GLASS-59 & 0.00310 & 0.48 & 2 & 4 \\
\hline A & GLASS-60 & 0.00658 & 1.02 & 20 & 2.5 \\
\hline A & GLASS-68 & 0.00319 & 0.49 & 3 & 4 \\
\hline$A$ & GLASS-69 & 0.00416 & 0.64 & 5 & 3.5 \\
\hline A & GLASS-70 & 0.00576 & 0.89 & 7 & 3 \\
\hline A & GLASS-71 & 0.00576 & 0.89 & 7 & 3 \\
\hline$A$ & GLASS-72 & 0.00576 & 0.89 & 7 & 3 \\
\hline
\end{tabular}

All glasses in category A pass the Cup Wall Stiffness Tests; two cups which are injection moulded GPPS with the potential to splinter and injure, notably glasses 9 and 45, have been withdrawn from category A in Table 11.6 below. 
Table 11.6: Category A with Splinterable Glasses Removed

\begin{tabular}{|c|c|c|c|c|c|}
\hline Category & Glass Ref.No. & $\begin{array}{c}\text { ReCiPe } \\
\text { Endpoints }\end{array}$ & $\begin{array}{l}\text { Ratio to the } \\
\text { Mean }\end{array}$ & Rank Order & Star Rating \\
\hline A & GLASS-01 & 0.00652 & 1.12 & 12 & 2 \\
\hline A & GLASS-02 & 0.00656 & 1.13 & 13 & 2 \\
\hline A & GLASS-12 & 0.00656 & 1.13 & 13 & 2 \\
\hline A & GLASS-14 & 0.00668 & 1.15 & 22 & 1.5 \\
\hline A & GLASS-16 & 0.00658 & 1.13 & 20 & 2 \\
\hline A & GLASS-17 & 0.00791 & 1.36 & 25 & 1.5 \\
\hline A & GLASS-20 & 0.00679 & 1.17 & 23 & 2 \\
\hline A & GLASS-22 & 0.00679 & 1.17 & 23 & 2 \\
\hline A & GLASS-26 & 0.00656 & 1.13 & 13 & 2 \\
\hline A & GLASS-28 & 0.00656 & 1.13 & 13 & 2 \\
\hline A & GLASS-30 & 0.00646 & 1.11 & 11 & 2 \\
\hline A & GLASS-33 & 0.00656 & 1.13 & 13 & 2 \\
\hline A & GLASS-47 & 0.00656 & 1.13 & 13 & 2 \\
\hline A & GLASS-50 & 0.00413 & 0.71 & 4 & 3 \\
\hline$A$ & GLASS-51 & 0.00656 & 1.13 & 13 & 2 \\
\hline A & GLASS-52 & 0.00615 & 1.06 & 10 & 2.5 \\
\hline A & GLASS-57 & 0.00416 & 0.71 & 5 & 3 \\
\hline A & GLASS-58 & 0.00307 & 0.53 & 1 & 3.5 \\
\hline A & GLASS-59 & 0.00310 & 0.53 & 2 & 3.5 \\
\hline A & GLASS-60 & 0.00658 & 1.13 & 20 & 2 \\
\hline A & GLASS-68 & 0.00319 & 0.55 & 3 & 3.5 \\
\hline A & GLASS-69 & 0.00416 & 0.71 & 5 & 3 \\
\hline A & GLASS-70 & 0.00576 & 0.99 & 7 & 2.5 \\
\hline A & GLASS-71 & 0.00576 & 0.99 & 7 & 2.5 \\
\hline$A$ & GLASS-72 & 0.00576 & 0.99 & 7 & 2.5 \\
\hline
\end{tabular}

Movement between the Rank Order number of the initial general category, shown in Table 11.1, and category A, with deductions for splinterable product, can be seen in Table 11.7 below, marked in yellow. The rational for dividing the data into quarters in Table 11.7 is to further highlight the movements in Rank Order number of the product due to these category changes.

The relative Rank Order of the products obviously remains the same, as the ReCiPe end point numeric values remain unchanged. Star Ratings can change due to changes in the means and standard deviations, and changes in ratings boundaries can separate two products previously having shared the same Star Rating. 
Table 11.7: Glasses undergoing a Rank Order Number Change due to Category FS changes

Rank Order Number and Position by Quarters

\begin{tabular}{|c|c|c|c|c|c|c|c|c|}
\hline \multirow{2}{*}{$\begin{array}{c}\text { Glass Ref. } \\
\text { No. }\end{array}$} & \multicolumn{4}{|c|}{ Category A Quarters (incl. deductions) } & \multicolumn{4}{|c|}{ General Category Quarters } \\
\hline & 1st & 2nd & 3rd & 4th & 1st & 2nd & 3rd & 4th \\
\hline GLASS-01 & & 12 & & & & & 39 & \\
\hline GLASS-02 & & & 13 & & & & 40 & \\
\hline GLASS-12 & & & 13 & & & & 40 & \\
\hline GLASS-14 & & & & 22 & & & 49 & \\
\hline GLASS-16 & & & & 20 & & & 47 & \\
\hline GLASS-17 & & & & 25 & & & & 58 \\
\hline GLASS-20 & & & & 23 & & & 51 & \\
\hline GLASS-22 & & & & 23 & & & 51 & \\
\hline GLASS-26 & & & 13 & & & & 40 & \\
\hline GLASS-28 & & & 13 & & & & 40 & \\
\hline GLASS-30 & & 11 & & & & & 38 & \\
\hline GLASS-33 & & & 13 & & & & 40 & \\
\hline GLASS-47 & & & 13 & & & & 40 & \\
\hline GLASS-50 & 4 & & & & 12 & & & \\
\hline GLASS-51 & & & 13 & & & & 40 & \\
\hline GLASS-52 & & 10 & & & & & 36 & \\
\hline GLASS-57 & 5 & & & & 13 & & & \\
\hline GLASS-58 & 1 & & & & 3 & & & \\
\hline GLASS-59 & 2 & & & & 4 & & & \\
\hline GLASS-60 & & & & 20 & & & 47 & \\
\hline GLASS-68 & 3 & & & & 5 & & & \\
\hline GLASS-69 & 5 & & & & 13 & & & \\
\hline GLASS-70 & & 7 & & & & 27 & & \\
\hline GLASS-71 & & 7 & & & & 28 & & \\
\hline GLASS-72 & & 7 & & & & 28 & & \\
\hline
\end{tabular}

It can be seen that eight of the 25 glasses change their Rank Order number. Glass-30 moves down a quarter and Glass-60 moves up a quarter, due to the change in category definition from the general category, identified in Table 11.1, to the high resolution category A, with deductions for splinterable glasses in Table 11.6.

These changes depend on the differences in the make-up of the category, such as in the case of different cup combinations with different product economic inventory as well as differences in band width. It may be possible that an item in the lower half of the Rank Order of one category could move to upper half of the Rank Order in another higher 
resolution category. Were this situation to occur, it would indicate the need for a welldefined and displayed category definition.

A claim reader could note that an item is generally of low environmental efficiency while not knowing the category FS. Were this item to appear in another higher resolution category with a high Rank Order score, this could lead to confusion.

In Chapter 7.8, reference is made to the use of CPA to define a category but this was noted as being limited in resolution. Energy labels, such as those of EU Directive 92/75/ EC energy-labelling scheme, have a single category for washing machines (http://eur-lex. europa.eu, accessed 24/09/2017). In the case of $\mathrm{CO}_{2}$ labelling of passenger cars in Europe, 9 defined vehicle category types exist (Haq, G., et al., 2016).

Conclusion: FS testing is needed to define a category as example category B of plastic drinking glasses shows.

\subsubsection{Cold Beverage Glasses - Material Composition}

In category A above, Glass-22 is an unmarked and unprinted glass. A simple Visual study of the glass might suggest that it is either made from PET or PLA, being visually comparable to other glasses which do exhibit an embossed material identification abbreviation. A Detailed study using FTIR spectroscopy reveals it is PLA.

In Table 11.8 below, based on a simple Visual study, the glass is assumed to be PET and is ranked 4th in the Rank Order. 
Table 11.8: Glass-22 in Category A, Assumed to be of PET material

\section{GLASS-22 = PET}

\begin{tabular}{|c|c|c|c|c|c|}
\hline Category & Glass Ref.No. & $\begin{array}{c}\mathrm{ReCiPe} \\
\text { Endpoints }\end{array}$ & $\begin{array}{c}\text { Ratio to the } \\
\text { Mean }\end{array}$ & Rank Order & Star Rating \\
\hline A & GLASS-01 & 0.00652 & 1.14 & 13 & 2 \\
\hline A & GLASS-02 & 0.00656 & 1.15 & 14 & 2 \\
\hline A & GLASS-12 & 0.00656 & 1.15 & 14 & 2 \\
\hline A & GLASS-14 & 0.00668 & 1.17 & 23 & 2 \\
\hline A & GLASS-16 & 0.00658 & 1.15 & 21 & 2 \\
\hline A & GLASS-17 & 0.00791 & 1.39 & 25 & 1.5 \\
\hline A & GLASS-20 & 0.00679 & 1.19 & 24 & 2 \\
\hline A & GLASS-22 & 0.00382 & 0.67 & 4 & 3.5 \\
\hline A & GLASS-26 & 0.00656 & 1.15 & 14 & 2 \\
\hline A & GLASS-28 & 0.00656 & 1.15 & 14 & 2 \\
\hline A & GLASS-30 & 0.00646 & 1.13 & 12 & 2 \\
\hline A & GLASS-33 & 0.00656 & 1.15 & 14 & 2 \\
\hline A & GLASS-47 & 0.00656 & 1.15 & 14 & 2 \\
\hline A & GLASS-50 & 0.00413 & 0.72 & 5 & 3 \\
\hline A & GLASS-51 & 0.00656 & 1.15 & 14 & 2 \\
\hline A & GLASS-52 & 0.00615 & 1.08 & 11 & 2.5 \\
\hline A & GLASS-57 & 0.00416 & 0.73 & 6 & 3 \\
\hline A & GLASS-58 & 0.00307 & 0.54 & 1 & 3.5 \\
\hline A & GLASS-59 & 0.00310 & 0.54 & 2 & 3.5 \\
\hline A & GLASS-60 & 0.00658 & 1.15 & 21 & 2 \\
\hline A & GLASS-68 & 0.00319 & 0.56 & 3 & 3.5 \\
\hline A & GLASS-69 & 0.00416 & 0.73 & 6 & 3 \\
\hline A & GLASS-70 & 0.00576 & 1.01 & 8 & 2.5 \\
\hline A & GLASS-71 & 0.00576 & 1.01 & 8 & 2.5 \\
\hline$A$ & GLASS-72 & 0.00576 & 1.01 & 8 & 2.5 \\
\hline
\end{tabular}


In Table 11.9 below, based on a Detailed study, the glass is confirmed as PLA and is ranked 23rd in the Rank Order.

Table 11.9: Glass-22 in Category A, Confirmed to be of PLA material

\begin{tabular}{|c|c|c|c|c|c|}
\hline \multicolumn{6}{|c|}{ GLASS-22 = PLA } \\
\hline Category & Glass Ref.No. & $\begin{array}{l}\text { ReCiPe } \\
\text { Endpoints }\end{array}$ & $\begin{array}{l}\text { Ratio to } \\
\text { the Mean }\end{array}$ & Rank Order & Star Rating \\
\hline$A$ & GLASS-01 & 0.00652 & 1.12 & 12 & 2 \\
\hline A & GLASS-02 & 0.00656 & 1.13 & 13 & 2 \\
\hline A & GLASS-12 & 0.00656 & 1.13 & 13 & 2 \\
\hline A & GLASS-14 & 0.00668 & 1.15 & 22 & 1.5 \\
\hline$A$ & GLASS-16 & 0.00658 & 1.13 & 20 & 2 \\
\hline$A$ & GLASS-17 & 0.00791 & 1.36 & 25 & 1.5 \\
\hline A & GLASS-20 & 0.00679 & 1.17 & 23 & 2 \\
\hline A & GLASS-22 & 0.00679 & 1.17 & 23 & 2 \\
\hline$A$ & GLASS-26 & 0.00656 & 1.13 & 13 & 2 \\
\hline$A$ & GLASS-28 & 0.00656 & 1.13 & 13 & 2 \\
\hline A & GLASS-30 & 0.00646 & 1.11 & 11 & 2 \\
\hline A & GLASS-33 & 0.00656 & 1.13 & 13 & 2 \\
\hline A & GLASS-47 & 0.00656 & 1.13 & 13 & 2 \\
\hline A & GLASS-50 & 0.00413 & 0.71 & 4 & 3 \\
\hline A & GLASS-51 & 0.00656 & 1.13 & 13 & 2 \\
\hline A & GLASS-52 & 0.00615 & 1.06 & 10 & 2.5 \\
\hline A & GLASS-57 & 0.00416 & 0.71 & 5 & 3 \\
\hline A & GLASS-58 & 0.00307 & 0.53 & 1 & 3.5 \\
\hline A & GLASS-59 & 0.00310 & 0.53 & 2 & 3.5 \\
\hline$A$ & GLASS-60 & 0.00658 & 1.13 & 20 & 2 \\
\hline A & GLASS-68 & 0.00319 & 0.55 & 3 & 3.5 \\
\hline A & GLASS-69 & 0.00416 & 0.71 & 5 & 3 \\
\hline$A$ & GLASS-70 & 0.00576 & 0.99 & 7 & 2.5 \\
\hline$A$ & GLASS-71 & 0.00576 & 0.99 & 7 & 2.5 \\
\hline A & GLASS-72 & 0.00576 & 0.99 & 7 & 2.5 \\
\hline
\end{tabular}

Taking a Detailed study significantly changes the Rank Order number of Glass-22 in this category. The PET glass is $56 \%$ of the ReCiPe endpoint value of the PLA version of the glass.

Conclusion: for these plastic drinking glasses, Material Composition analysis is needed to define ranking within a category, in the event that the material composition is not available from a stakeholder. 


\subsubsection{Cold Beverage Glasses - Country of Origin}

The identification of PLA as the material type used to manufacture Glass-22 is significant as regards countries of origin. PLA material is manufactured in Nebraska in the USA. This may contribute to different granule packaging and to a different transport profile, compared to PET.

In the above Tables 11.8 and 11.9, Glass-22 was assumed to have been made in Germany. This was simply to provide a comparison of the additional impacts associated with a change in materials based on the glass being produced in the same country.

Expert opinion confirms that PLA glasses in the Dutch market are typically from several different German and Taiwanese manufactures. Germany also supplies PP and some PS glasses, whereas the Taiwanese appear to only supply PLA glasses in the Netherlands. 
In this case, had the PLA been identified as Taiwanese, the glass would have dropped further in the Rank Order and Star Rating, as can be seen below in Table 11.10.

Table 11.10: Glass-22 in Category A, Confirmed to be Manufactured in Taiwan of PLA material

\begin{tabular}{|c|c|c|c|c|c|}
\hline \multicolumn{6}{|c|}{ GLASS-22 = PLA TAIWAN } \\
\hline Category & Glass Ref.No. & $\begin{array}{c}\text { ReCiPe } \\
\text { Endpoints }\end{array}$ & $\begin{array}{l}\text { Ratio to the } \\
\text { Mean }\end{array}$ & Rank Order & Star Rating \\
\hline A & GLASS-01 & 0.00652 & 1.11 & 12 & 2 \\
\hline A & GLASS-02 & 0.00656 & 1.12 & 13 & 2 \\
\hline A & GLASS-12 & 0.00656 & 1.12 & 13 & 2 \\
\hline A & GLASS-14 & 0.00668 & 1.14 & 22 & 2 \\
\hline A & GLASS-16 & 0.00658 & 1.12 & 20 & 2 \\
\hline A & GLASS-17 & 0.00791 & 1.34 & 24 & 1.5 \\
\hline A & GLASS-20 & 0.00679 & 1.15 & 23 & 2 \\
\hline A & GLASS-22 & 0.00829 & 1.41 & 25 & 1.5 \\
\hline A & GLASS-26 & 0.00656 & 1.12 & 13 & 2 \\
\hline A & GLASS-28 & 0.00656 & 1.12 & 13 & 2 \\
\hline A & GLASS-30 & 0.00646 & 1.10 & 11 & 2.5 \\
\hline A & GLASS-33 & 0.00656 & 1.12 & 13 & 2 \\
\hline A & GLASS-47 & 0.00656 & 1.12 & 13 & 2 \\
\hline A & GLASS-50 & 0.00413 & 0.70 & 4 & 3.5 \\
\hline A & GLASS-51 & 0.00656 & 1.12 & 13 & 2 \\
\hline A & GLASS-52 & 0.00615 & 1.05 & 10 & 2.5 \\
\hline A & GLASS-57 & 0.00416 & 0.71 & 5 & 3 \\
\hline$A$ & GLASS-58 & 0.00307 & 0.52 & 1 & 3.5 \\
\hline$A$ & GLASS-59 & 0.00310 & 0.53 & 2 & 3.5 \\
\hline A & GLASS-60 & 0.00658 & 1.12 & 20 & 2 \\
\hline A & GLASS-68 & 0.00319 & 0.54 & 3 & 3.5 \\
\hline A & GLASS-69 & 0.00416 & 0.71 & 5 & 3 \\
\hline A & GLASS-70 & 0.00576 & 0.98 & 7 & 2.5 \\
\hline A & GLASS-71 & 0.00576 & 0.98 & 7 & 2.5 \\
\hline A & GLASS-72 & 0.00576 & 0.98 & 7 & 2.5 \\
\hline
\end{tabular}


In Table 11.11 below, the transport associated with PLA when the glass is made in Germany is significant between a PET and PLA version. This figure rises again for a Taiwanese PLA glass.

Table 11.11: Transport Associated with Glass-22 in Tables 11.8, 11.9 and 11.10

\begin{tabular}{|c|c|c|c|c|c|}
\hline Material & Glass Ref.No. & $\begin{array}{c}\text { Country of } \\
\text { Origin }\end{array}$ & $\%$ Transport & Rank Order & Star Rating \\
\hline PET & GLASS-22 & Germany & 2.25 & 4 & 3.5 \\
\hline PLA & GLASS-22 & Germany & 4.61 & 23 & 2 \\
\hline PLA & GLASS-22 & Taiwan & 6.36 & 25 & 1.5 \\
\hline
\end{tabular}

The "Four-in-one" recycling symbol is required for products sold in Taiwan (http://law.moj. gov.tw/Eng/LawClass/LawAll.aspx?PCode=00050001 cited 29/09/2017), while a German product may simply display the Society of Plastics Industry Resin Identification Code (numbering from 1 to 7), in this case 7 for "other materials" which also includes PLA. The Taiwanese resin code would require the English acronym of the plastic, in this case PLA.
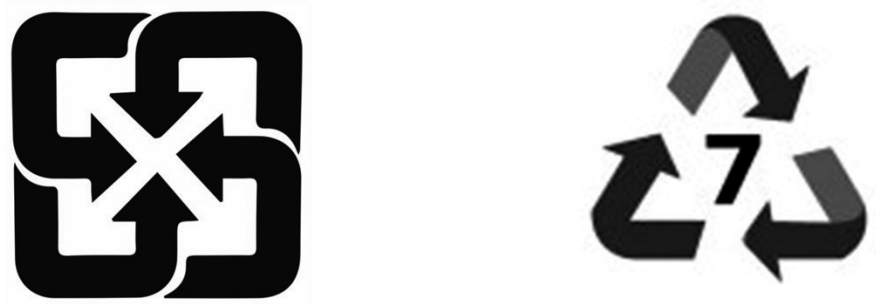

\section{PLA}

Figure 11.3: The Taiwanese "Four-in-one" Recycling Symbol and Resin Identification Code

The inclusion or exclusion of these symbols, and the form they take, would act to further aid in identifying the source of the drinking glass manufacture.

It is also possible that some glasses are embossed with fill lines to identify the quantity of beverage at the fill line. To support these fill line volumes, there is often a CE marking. This marking, as seen below in Figure 11.4, makes reference to the production year and the notifying body. This may further act to support a conclusion as to the $\mathrm{CoO}$ of a product, as it may be likely that the product manufacturer will apply to a local body for the CE marking. This is only possible in FSD products for which a volume of contents is measurable (http:// www.ce-marking.org/list-of-notified-bodies.html, cited 31/07/2018). 


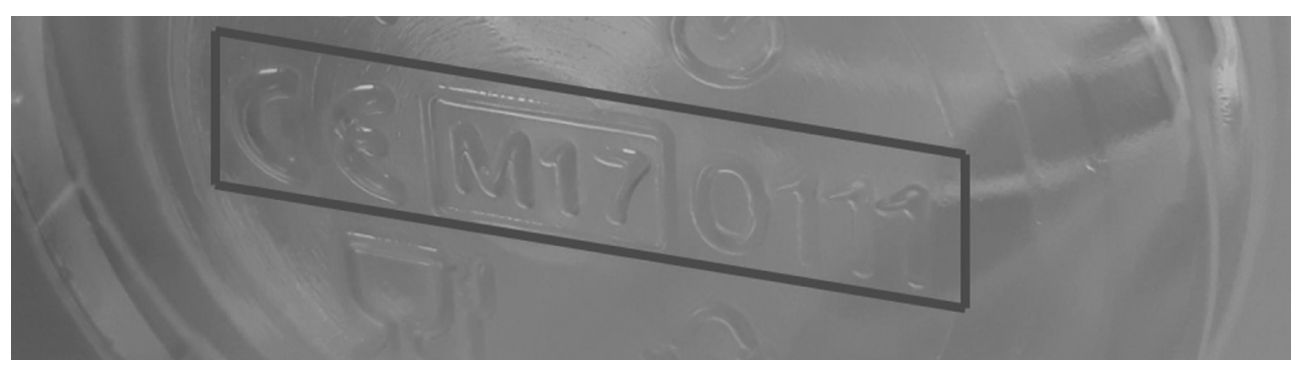

Figure 11.4: A CE Marking on the Base of a Plastic Drinking Glass

In this case, a mixture of materials identification, raw material source knowledge, disposable drinking glass market knowledge and legal requirements regarding recycling symbols, aid in identifying the $\mathrm{CoO}$ of the product.

Had there been access to be had to the secondary and tertiary packaging of the glasses, further opportunities to confirm the $\mathrm{CoO}$ may have been possible.

Conclusion: for plastic drinking glasses, $\mathrm{CoO}$ has to be known to rank items within a category.

\subsubsection{Cold Beverage Glasses - Knowledge}

At various points in the above study of glasses, product specific knowledge is used, with that knowledge being both technical and market/product based.

While the FS choices are subjective in nature, their compliance can be rendered objective by mechanical testing and the use of associated testing knowledge.

In the case of materials identification, this influences processing choices. PET and PLA require drying prior to processing compared to PS and PP. PET can be supplied in tankers like PS and PP, whereas PLA is typically supplied in sealed aluminum lined bags in Octobins.

Regarding countries of origin, PET can come from various sources, whereas PLA is typically from a single specific source. This requires FSD material sourcing knowledge. Knowledge of symbols and abbreviations typically found on glasses and their packaging also contributes, in this case, to country of origin identification.

Conclusion: product marketing and technologically relevant knowledge is required to identify the product inventory data to be used within a product LCA.

\subsubsection{Cold Beverage Glasses - Conclusion}

Had a simple visual, or traditional, based approach been taken regarding the product economic inventory in this category the effect of a potentially incorrect material choice would have been significant. If the operative were to decide that either PET or PLA was the possible cup material, any uncertainty analysis would produce an extreme difference 
in result regarding the position of the glass within the category. Essentially, in one case it is 4 th best, in the other, it is worst or second worst, out of the 25 glasses in the category.

This extreme difference is significant, given the very similar nature of the products which are essentially all made of transparent plastic using many of the same processing techniques. It could be questioned whether, if a greater range of diverse material types and processes were to be found in the same category, this may drive an even greater need for a FUMCO type approach to product economic inventory input for the LCA.

Conclusion: FUMCO can aid in identifying objective and credible product economic inventory data in support of a comparative LCA study used to rank FSD within a defined category.

\subsection{Test No.2 - Across Multiple FSD types}

In test No. 2, three different FSD types will be used, each to test a different part of the first three parts of the FUMCO method as listed below.

1. Functional Unit (FU) and its associated Functional Specification (FS)

2. Material Composition (MC)

3. Country of Origin (CoO)

4. Requirement for Technologically Relevant Knowledge (TRK) regarding the product

Hence each part is tested against a different FSD product type, these FSD products being:

1. for FS identification - FSD spoons

2. for MC identification - FSD soup bowls

3. for CoO identification - FSD take-out meal trays

4. TRK as relates to these three FSD product studies will also be addressed

Testing against three different FSD types further spreads the product types against which the FUMCO approach is tested.

\subsubsection{Functional Specification Identification - FSD Spoon}

In order to assess the value of a FUMCO approach to identifying the FS of a product for compliance to a specific product category, a series of eight FSD spoons were purchased from the Dutch food service and retail markets on 24th August 2014.

The focus here is on the FS of the spoon, so other factors unrelated to the FS, such as MC or $\mathrm{CoO}$, have been adopted and remain the same across this specific spoon study. 


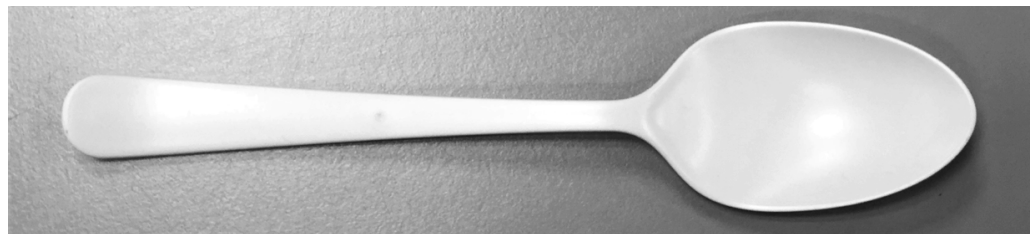

Figure 11.5: FSD Spoon

A typical FSD spoon is lightweight and fit for purpose, designed to facilitate the consumption of liquid foods as well as solid foods that do not necessarily require cutting. The average spoon length and weight can be seen in Table 11.12 below:

Table 11.12: Average FSD Spoon Length and Weight

\begin{tabular}{|c|c|c|}
\hline Spoon Ref.No. & Weight (g) & Length $(\mathrm{mm})$ \\
\hline Sp-1 & 2.639 & 170.00 \\
\hline Sp-2 & 2.491 & 165.00 \\
\hline Sp-3 & 2.555 & 166.00 \\
\hline Sp-4 & 3.175 & 166.00 \\
\hline Sp-5 & 2.750 & 157.00 \\
\hline Sp-6 & 3.035 & 170.00 \\
\hline Sp-7 & 2.938 & 170.00 \\
\hline Sp-8 & 3.198 & 170.00 \\
\hline Average & 2.850 & 166.75 \\
\hline
\end{tabular}

While weight and length could be used to define a category of FSD spoons, they are not an indication of the spoon's ability to function. Strength, with regard to these light weight items, would appear important in terms of FS. This is particularly evident for a light weight cutlery item like an FSD spoon which is subject to considerable pressure during use.

A spoon that breaks easily may do so due to factors such as material weight or composition or due to the design benefitting the cost of the item over the function or strength of the item. Such factors could also lead to the spoon achieving a lower ReCiPe endpoint figure and hence achieving a better ranking and rating, while also distorting the average $\mathrm{ReCiPe}$ endpoint figure of the category. This would potentially lead to an unrepresentative result with regard to the ECS, as the function of the spoon has not been fully considered.

The market will require spoons with which it is able to eat products of a certain weight. Because of the dynamic behaviour, this requires a carrying force of approximately $18 \mathrm{~N}$.

Each of the FSD spoons were subjected to strength tests, using an UTI instrument measuring compression break force as referred to in Chapter 7.4.1. The average break 
force in Newtons for all spoons except Sp-5 was 18.23N, for Sp-5 the average break force was $9.42 \mathrm{~N}$. Sp-5 was the second lightest weight spoon in the category. Spoon Sp-5 was subsequently removed from the category.

Table 11.13: FSD Spoon Category - Including and Excluding the Lower Strength Sp-5

\begin{tabular}{cc|c|c|c}
\hline \multicolumn{5}{c}{ Including Spoon Sp-5 } \\
\hline $\begin{array}{c}\text { Spoon } \\
\text { Ref. } \\
\text { No. }\end{array}$ & $\begin{array}{c}\text { ReCiPe } \\
\text { End- } \\
\text { points }\end{array}$ & $\begin{array}{c}\text { Ratio } \\
\text { to the } \\
\text { Mean }\end{array}$ & $\begin{array}{c}\text { Rank } \\
\text { Order }\end{array}$ & $\begin{array}{c}\text { Star } \\
\text { Rating }\end{array}$ \\
\hline$S p-1$ & 0.00212 & 0.97 & 4 & 3 \\
\hline$S p-2$ & 0.00186 & 0.85 & 2 & 4 \\
\hline$S p-3$ & 0.00203 & 0.93 & 3 & 3 \\
\hline$S p-4$ & 0.00254 & 1.17 & 7 & 1 \\
\hline$S p-5$ & 0.00183 & 0.84 & 1 & 4 \\
\hline$S p-6$ & 0.00216 & 0.99 & 5 & 2.5 \\
\hline$S p-7$ & 0.00233 & 1.07 & 6 & 2 \\
\hline$S p-8$ & 0.00254 & 1.17 & 7 & 1 \\
\hline
\end{tabular}

Excluding Spoon Sp-5

\begin{tabular}{c|c|c|c|c}
\hline $\begin{array}{c}\text { Spoon } \\
\text { Ref. } \\
\text { No. }\end{array}$ & $\begin{array}{c}\text { ReCiPe } \\
\text { End- } \\
\text { points }\end{array}$ & $\begin{array}{c}\text { Ratio } \\
\text { to the } \\
\text { Mean }\end{array}$ & $\begin{array}{c}\text { Rank } \\
\text { Order }\end{array}$ & $\begin{array}{c}\text { Star } \\
\text { Rating }\end{array}$ \\
\hline Sp-1 & 0.00212 & 0.95 & 3 & 3 \\
\hline$S p-2$ & 0.00186 & 0.84 & 1 & 4 \\
\hline$S p-3$ & 0.00203 & 0.91 & 2 & 3.5 \\
\hline$S p-4$ & 0.00254 & 1.14 & 6 & 1 \\
\hline$S p-5$ & - & - & - & - \\
\hline$S p-6$ & 0.00216 & 0.97 & 4 & 3 \\
\hline$S p-7$ & 0.00233 & 1.05 & 5 & 2 \\
\hline$S p-8$ & 0.00254 & 1.14 & 6 & 1 \\
\hline
\end{tabular}

The removal of Sp-5 increases the Star Rating of Sp-6 and Sp-3, with Sp-2 now being the best in class product.

While Sp-5 was among the items in a Primary Category of FSD spoons, it could be seen not to function to the same extent as the other FSD spoons in the category. For this reason, it could be removed from the Final Category. While this is a subjective choice, should strength have been a factor in the PFR then the use of physical and mechanical testing could facilitate the objective identification of compliant spoons.

Conclusion: the use of the FUMCO method to qualify and quantify the function of an item can lead to changes in the ranking and rating of a category of like functionality products in a comparative LCA based study. 


\subsubsection{Material Composition Identification - FSD Soup Bowl}

In order to assess the value of a FUMCO approach to identifying the material composition of a product, a series of six FSD soup bowls were purchased from the Dutch food service and retail markets on 24th August 2014.

The focus here is on the material composition, so other factors unrelated to the material composition, such as $\mathrm{CoO}$, have been adopted and remain the same across this specific soup bowl study. In the event that an additional material component, other than what would be assumed in a purely visual study of the product, was identified then the associated material conversion processes will be assumed to have taken place in the $\mathrm{CoO}$ of the product as it was listed in the purely visual study of the product.

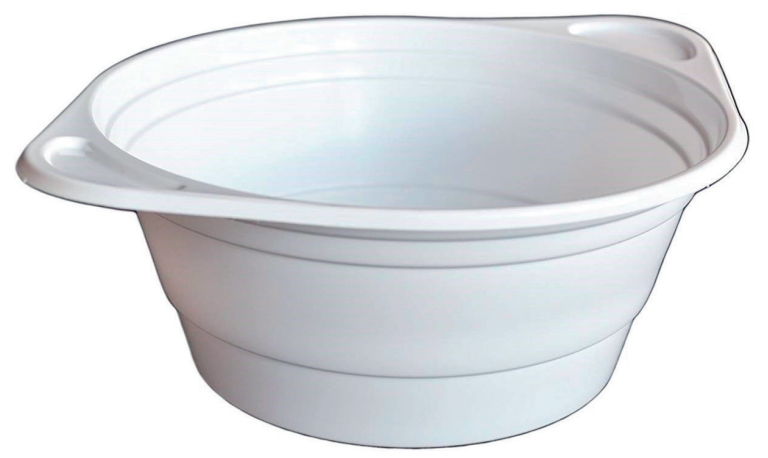

Figure 11.6: FSD Soup Bowl

The FSD soup bowls are opaque white. The question is if the LCA operative is aware of how the opacity is achieved in this type of plastic item. One could even question whether the operative could identify the basic plastic type used to make the soup bowl, as was the case in the EU LCA study of paper cup lids (see Chapter 10.2.3). In the purely visual based study below, see Table 11.14, the assumption is that the operative correctly identifies the plastic type and is aware that $\mathrm{TiO}_{2}$ masterbatch is typically used to achieve opacity, with a net $\mathrm{TiO}_{2}$ loading of $2 \%$.

Table 11.14: Soup Bowl Category - Based on a Purely Visual Assessment of Bowl-5

\begin{tabular}{c|c|c|c|c}
\hline Bowl Ref.No. & \multicolumn{1}{c}{ ReCiPe Endpoints } & \multicolumn{1}{c}{ Ratio to the Mean } & Rank Order & Star Rating \\
\hline Bowl-1 & 0.00314 & 1.07 & 5 & 2 \\
\hline Bowl-2 & 0.00268 & 0.91 & 1 & 3.5 \\
\hline Bowl-3 & 0.00280 & 0.95 & 2 & 3 \\
\hline Bowl-4 & 0.00297 & 1.01 & 4 & 2.5 \\
\hline Bowl-5 & 0.00287 & 0.98 & 3 & 2.5 \\
\hline Bowl-6 & 0.00315 & 1.07 & 6 & 2 \\
\hline
\end{tabular}


Following the instrument based analytical processes described in Chapter 8.2.2, it was noted that Bowl -5 had a content of mineral filler, notably $20 \%$ by weight of $\mathrm{CaCO}_{3}$, which is a common filler in PP products. Having reappraised the material composition of Bowl-5, the ReCiPe endpoint numeric value lowers by $12.90 \%$, this having a significant impact on the comparative rating score for this product.

Table 11.15: Soup Bowl Category - Based on an Instrumental Assessment of Bowl-5

\begin{tabular}{c|c|c|c|c}
\hline Bowl Ref.No. & \multicolumn{1}{c}{ ReCiPe Endpoints } & Ratio to the Mean & Rank Order & Star Rating \\
\hline Bowl-1 & 0.00314 & 1.09 & 5 & 1.5 \\
\hline Bowl-2 & 0.00268 & 0.93 & 3 & 3 \\
\hline Bowl-3 & 0.00280 & 0.97 & 4 & 2 \\
\hline Bowl-4 & 0.00297 & 1.03 & 1 & 4 \\
\hline Bowl-5 & 0.00250 & 0.87 & 6 & 1.5 \\
\hline
\end{tabular}

The identification of the filler and the association of the processes used to incorporate the filler into the material composite have caused the Star Rating of Bowl-5 to move from 2.5 Stars to 4 Stars.

Conclusion: the use of the FUMCO method to exactly qualify and quantify the material composition of an item has caused it to change its ranking and rating in a comparative LCA based study of a category of like functionality products.

\subsubsection{Country of Origin Identification - FSD Take-Out Meal Tray}

In order to assess the value of a FUMCO approach to identifying the $\mathrm{CoO}$ of a product, a take-out tray labelled MT-1, in a series of ten take-out meal trays, was studied. These trays are the type of FSD products previously described in Subchapter 7.6. 
The specific focus in this range of items is tray reference MT-1, which is a carton cup like food box with integrated lid as can be seen in Figure 11.7 below.

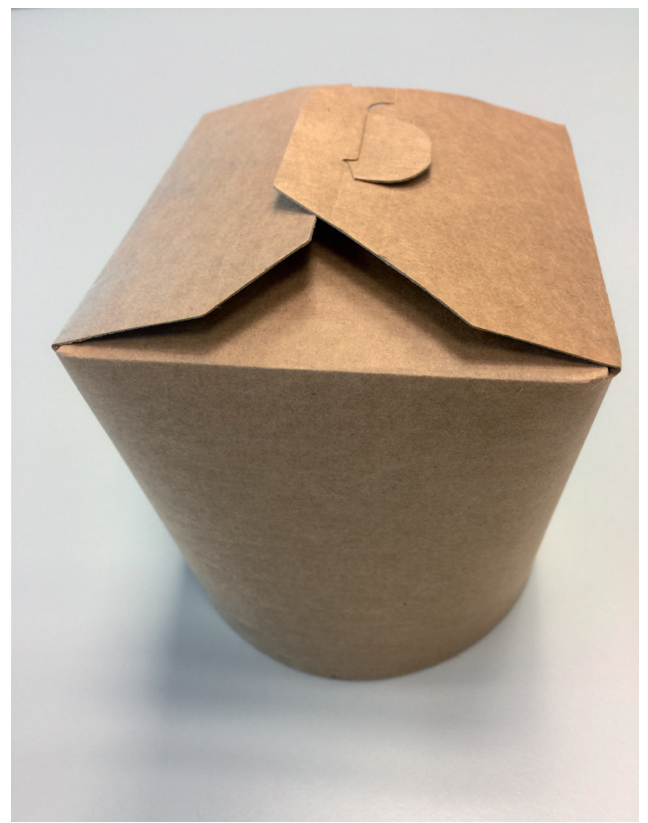

Figure 11.7: PLA Coated Meal Tray MT-1

Meal Tray MT-1 exhibits no printing or embossing and was identified, using FTIR spectroscopy, as having a PLA inner wall coating. The shape and form of the meal tray would suggest a leading manufacturer of this meal tray type based in the USA but this manufacturer does not offer a PLA coated version. Study of a similar kraft coloured type product from the USA manufacturer shows the board as having a different visual aspect, see Figure 11.8 below, in which the board at the top of the photograph is from MT-1 and the board below it being from the USA. This caused the experts (Appendix $L$ ) to dismiss the MT-1 board as being from the USA. 


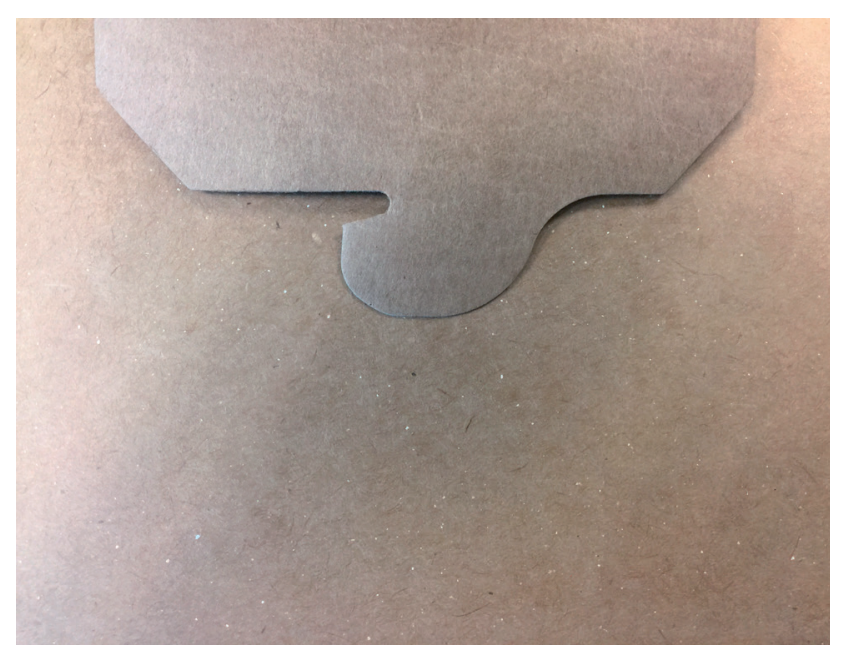

Figure 11.8: MT-1 Board at Top of Photograph with a USA Board Below

The experts then stated that two options were hence available as regards the $\mathrm{CoO}$ of MT-1, one being Turkish and the other Chinese. FTIR spectroscopy identified a 96.48\% match to the Chinese product and an $81.07 \%$ match to the Turkish product. Eleven inorganic elements were identified in the Chinese product using XRF spectroscopy while eight were identified in the Turkish product. MT-1 exhibited the same elements as the Chinese product with roughly the same percentages as correlates between the elements. The measurement of iron in the MT-1 and Chinese products were very similar and was over 10 times higher than for the Turkish product.

Expert opinion backed up with instrumental analysis identified the MT-1 as being the same as a product made by SowinPak in China.

MT-1 had been manufactured in China. The method of $\mathrm{CoO}$ identification in this case was based on identifying the material used to make MT-1. To further support this conclusion, a study was made of the shrink film and label used to pack the MT-1 products, these correlating with a high match to the SowinPak product and not to the Turkish pack.

In Table 11.16 below, the Detailed study results are compared with a Visual study; in this case, MT-1 achieves a 4 Star rating based on the assumption of Turkish production and PE coating compared to a 3.5 Star rating when the actual MT-1 CoO and MC were studied. Having reappraised the $\mathrm{CoO}$ and $\mathrm{MC}$ of $\mathrm{MT}-1$, the ReCiPe endpoint numeric value increases by $21.3 \%$, this having a significant impact on the comparative rating score for this product. 
Table 11.16: Visual versus Detailed Study involving the MT-1 Observation in the above Text

\begin{tabular}{c|c|c|c|c|c|c}
\hline \multicolumn{7}{c}{ Visual Study } \\
$\begin{array}{c}\text { Meal Tray } \\
\text { Ref.No. }\end{array}$ & $\begin{array}{c}\text { ReCiPe } \\
\text { Endpoints }\end{array}$ & Rank Order & Star Rating & $\begin{array}{c}\text { ReCiPe } \\
\text { Endpoints }\end{array}$ Rank Order & Star Rating \\
\hline 1 & 0.01070 & 3 & 4 & 0.01298 & 3 & 3.5 \\
\hline 2 & 0.00728 & 1 & 4 & 0.00593 & 1 & 4.5 \\
\hline 3 & 0.02619 & 7 & 2 & 0.02619 & 7 & 2 \\
\hline 4 & 0.00971 & 2 & 4 & 0.00971 & 2 & 4 \\
\hline 5 & 0.04707 & 10 & 0 & 0.04707 & 10 & 0 \\
\hline 6 & 0.02200 & 6 & 2.5 & 0.02844 & 8 & 2 \\
\hline 7 & 0.01720 & 5 & 3 & 0.01720 & 5 & 3 \\
\hline 9 & 0.03459 & 9 & 1 & 0.03459 & 9 & 1 \\
\hline 10 & 0.01692 & 4 & 3 & 0.01692 & 4 & 3 \\
\hline
\end{tabular}

Conclusion: the use of the FUMCO method to identify the $\mathrm{CoO}$ of an item has caused it to change its ranking and rating in a comparative LCA based study of a category of like functionality products.

\subsubsection{Technologically Relevant Knowledge Valuation as related to the Test No.2 Products}

1. The Functional Specification identification of the FSD spoon requires knowledge as to what to test for as regards the function of the spoon and how to carry out such tests.

2. The Material Composition identification of the FSD soup bowl requires knowledge as to what material components may be in the soup bowl material and how to analyse the material for its composition. This requires understanding of the associated materials analysis and interpretation from an FSD technologically relevant perspective. It also requires manufacturing or processing knowledge to understand the conversion processes associated with the identified materials.

3. The country of origin identification of the FSD take-out meal packs requires knowledge as to the materials used to make the meal pack and how to analyse the pack for its material composition. This requires understanding of the associated materials analysis and interpretation in terms of likely sources of meal packs made using the identified material. It also requires knowledge of the various meal packs and meal pack outer packaging, sources and their distinctive features as well as the knowledge to keep comparative libraries of spectra and other distinguishing product features up to date.

Conclusion: Technologically Relevant Knowledge is required to efficiently and accurately identify, analyse and interpret the approach required and results achieved in establishing product economic inventory data for comparative LCA input in the absence of stakeholders. 


\subsection{Chapter 11 Conclusions}

It has been demonstrated that inaccuracy in product economic inventory data can substantially affect the calculated LCA rating for the products concerned.

Where like functionality products are to be ranked and rated based on the results of a comparative LCA, for which there is no stakeholder sourced product economic inventory data, it would appear that FUMCO can aid in improving the accuracy and objectivity of this data. FUMCO could aid in reducing the chance of low quality input, often referred to as GIGO (Garbage In, Garbage Out), in such a study. GIGO is undesired, especially in a comparative study of products in which some products could be incorrectly ranked and rated.

It would appear that FUMCO can contribute accuracy to almost any type of FSD category under study. In the event of a lack of FSD technologically relevant knowledge, this would seem obvious. With this FSD technical knowledge being most relevant in terms of defining what should be researched and how to interpret the results of this research, the research method in this case being FUMCO.

In this chapter, an individual target product was studied from a variety of like functionality product categories in order to show movement in ranking and rating of that target product due to inventory changes between a purely visual inspection of the product and a FUMCO study. The inventory of the remaining products in the category were assumed to be unchanged in order to show the movement of that target product. This movement of a single target product in the category is just as likely to occur for all the other products in the category; this may lead to a further divergence in final ranking and rating between a study based on a purely visual assessment of the product inventory and a FUMCO approach, with all FSD products having the potential for product economic inventory data changes due to a FUMCO approach to the collection of this data in place of a purely visual approach.

The variety and diversity of FSD products, as described in Chapter 2, would indicate that most FSD could have visually unidentifiable product inventory which could otherwise be identified in a product economic inventory collection approach such as FUMCO.

The time taken to carry out FUMCO related studies is relatively short, with little requirement for sample preparation and spectroscopy processes that take only small amounts of time. It could be questioned if the time taken to carry out FUMCO, for the inventory data accuracy achieved, is more efficient than for the visual or traditional based methods as described in Subchapter 5.2.

\section{Functional Unit - FU}

While it has been established that FUMCO can contribute to increased objectivity in the study of comparative claims based on LCA studies in the absence of stakeholders, it is evident that subjectivity still plays a major role, this subjectivity being most apparent in 
establishing the FS desired to be represented within the category. It could be that this subjectivity could be addressed by assigning an independent third party body to define the FS of the product category.

It could also be questioned if these subjective FS choices, even with objective testing, could be used to define a limited category in which a biased result could be derived and be seen as subjective. It could be questioned that a point might be arrived at where only a single product is compliant to the FSR. This would obviously not form a category, as no comparison would exist, but it may fully represent the functional benefits of the product.

To counter these questions, it could be that a more general, lower resolution category could be seen to be less biased. This approach may disregard certain functional benefits that then go unrepresented within a category.

It could be questioned if an objective rule can be set for category FS choices and, if not, the extent to which subjectivity creates issues of credibility in the making of comparative claims of this type. This may have implications for PEF and EPD.

FU and FSR can be objectively measured but FS choices are subjective and would not appear to be objectively measurable.

It is understood that simply using "vehicle" as an FSR is largely questionable and hence "classes of vehicle" are established as separate categories. Questions should be addressed regarding the limitation of the resolution of the class and what level of resolution is acceptable in an attempt to stay as objective as possible.

In a category of fairly similar products, such as the above glasses, if an early correct assumption is made for a product then it may be likely to be adopted for the other products in the category given their similarity. In a category of very diverse product types providing the same FS, each product study risks to contribute little to the knowledge required to correctly allocate process to the next product along within the category.

\section{Material Composition - MC}

The research in this chapter further served to confirm the advantage of FUMCO in materials composition identification and the associated processing, compared to taking the Visual study approach.

\section{Country of Origin - CoO}

Regarding the country of origin identification benefits of FUMCO, it is evident that the materials identification provides an initial benefit in $\mathrm{CoO}$ identification. Thereafter, expert witness and comparative spectroscopy further contribute to $\mathrm{CoO}$ identification. It would appear important that expert knowledge and any comparative samples/spectra be maintained up to date. 


\section{Knowledge}

The lack of technologically relevant knowledge in LCA studies, as cited in various research papers, can be seen to be a valid and significant critique based on the research within this study. There are many points within the comparative study of FSD products that require technologically relevant knowledge as well as market/product knowledge. The lack of this knowledge can be seen to produce results that do not reflect the true position of a product within a comparative claim.

The need for technologically relevant knowledge of FSD could be seen to be far more important if there is no product stakeholder providing product economic inventory data.

It may be that FSD technologically relevant knowledge on its own would not be enough to accurately identify the product economic inventory data without the use of instrumentation and analytical techniques, although the knowledge could provide guidance as to what to study and how to interpret the study results.

It would appear that taking a Visual, or traditional, study approach, compared to a FUMCO approach including technical and product relevant knowledge, could misrepresent products within a category. The choices in a Visual study are potentially more subjective whereas the FUMCO approach may be considered more objective or could at least bring more objectivity to the study.

In the next chapter, Chapter 12, the FUMCO approach to product inventory identification will be examined with LCA experts. Subsequently, in Chapter 13, a critique of the advantages and shortcomings of the FUMCO approach will be addressed, as well as the final overall conclusions of this study. 


\section{Chapter 12}

\section{Expert Opinion, Discussions and Considerations}


The FUMCO method, as evolved and researched in Part 2 of this study, is proposed as a possible method to efficiently source and increase product economic inventory data accuracy and hence contribute to objectivity.

The question is to what extent this proposed method will contribute to increase accuracy, objectivity and confidence in comparable studies while reducing the time factor and hence cost of such studies. To what extent could the method contribute to the comparative study of the large number of embodied-impact-only product categories within the economy?

In Subchapter 10.2, LCAs were researched in which erroneous choices and assumptions had been adopted. Research reveals that such LCA studies are not difficult to identify, suggesting that LCA is also prone to being affected by the quality of the input (GIGO).

In Subchapter 5.2.1, research of academic papers describes the challenges associated with product life cycle inventory collection, even suggesting that studies are likely to be abandoned if the inventory data is not easily accessible. Product life cycle economic inventory collection is cited as one of the most time consuming activities in LCA. In Subchapter 5.2.2, the issue of time and its associated cost is described as a factor in inventory collection by LCA experts.

\subsection{Expert Opinion}

To move beyond desk research and testing, interviews with LCA experts were conducted in the expectation that their contribution would help to further critique and evolve the FUMCO method.

It was decided to involve some of the experts that were already interviewed in an earlier stage, the reasons being that there was a limited number of experts available and that they were already familiar with the study. The LCA expert interviews were all held separately from one another.

In Chapter 5, several of the respondents to the questionnaire stated that they were not actively carrying out LCA studies, even if they had previously contributed significantly to the research and development of LCA methods. Their insight, when provided, was of value and it could be that their further insight should be gleaned.

A greater depth of insight may be required which would suggest the use of conversation and debate involving interviews.

The two LCA expert based research communication approaches were:

1. Email questionnaire and email response

2. Face-to-face interviews 
It is the reflections of the experts that is recorded; this qualitative approach does not function as a concrete test of the FUMCO approach.

\subsubsection{The LCA Experts Interviewed}

The experts chosen to interview were chosen from organizations using LCA studies and those actively involved in producing LCA studies. A number of these experts have also been formative in the history and development of LCA.

Of the initial ten experts contacted, four from LCA consultancy agencies and one from academia have participated in the interview (see Appendix M). Of the ten candidates, three did not reply, one being a raw material manufacture who regularly purchases LCAs of their products, another being a foremost LCA consultancy based in the USA and another being a university lecturer.

There were then two other candidates that participated, one from an NGO that regularly works with LCA and the other, a waste management company active in the end-of-life scenario of products like FSD. In both these cases, their answers indicated a lack of understanding or confusion as to the subject of the questionnaire.

The choice of consulting with operatives of leading LCA consultancy agencies is that it is their line of expertise to produce LCA studies, many of which will be product studies of a type that may or may not benefit from a FUMCO approach. The choice of consulting with academics is to obtain a perspective from those parties involved in researching, developing and teaching product LCA.

These experts were sent a questionnaire, with a request to reflect on the points in the questionnaire. The exact questionnaire sent to each of the interviewees, or used when conducting a face-to-face interview, can be seen in Appendix N.

\subsubsection{Expert - Email Questionnaire}

The initial email questionnaire used within the research in Chapter 5 posed the question as to how product economic inventory life cycle data is typically accessed in the absence of stakeholders. The email questionnaire used in this chapter introduced the FUMCO method and requested reflection and critique thereupon.

The primary questions within the questionnaire are:

\section{Functional Unit}

As category membership will affect the rank order, or order of merit, of an item within a category, it would seem important that a product correctly complies with the category rules. In identifying compliance to the functional specification of the study functional unit within a like functionality product category, the use of physical and mechanical testing instrumentation will increase the objectivity of category compliance. Do you feel 
this approach is useful? Are there any ways in which you feel this approach is not useful, valid or relevant?

\section{Material Composition}

When presented with the category of compliant products, the materials and processing details are then required. To establish these, various laboratory instruments (i.e. $x$-ray and infra-red spectroscopy), combined with the use of stoichiometric chemistry, can aid in objectively identifying material components. These components then aid in identifying the processes used to manufacture the components and the final product. Do you feel this approach could be useful? Are there any ways in which you feel this approach is not useful, valid or relevant?

\section{Country of Origin}

Having listed the materials and processes associated with the category compliant products, it is then important to identify their component and finished product countries of origin. Using product experts and various laboratory instruments (i.e. Isotope ratio mass spectrometry, x-ray and infra-red spectroscopy) with the relevant libraries, the associated country of origin may be identified. Do you feel this approach is useful? Are there any ways in which you feel this approach is not useful, valid or relevant?

\section{Product Technologically Relevant Knowledge}

A significant number of LCA studies have been identified in which the lack of technologically relevant knowledge has led to erroneous results. The operative involved in a comparative product LCA study should possess the technologically relevant knowledge of the products, with significant time spent in the manufacturing of the products under study. Do you feel this approach is necessary to complete a viable study? Are there any ways in which you feel this approach is not necessary, valid or relevant?

During the email or verbal conversations, following on from the introductory example questions listed above, product examples of each of the FUMCO parts were discussed where relevant.

\subsubsection{The LCA Expert Interviews}

Table 12.1 lists the condensed reaction of the candidate to the questions posed in the above questionnaire. Where both agreed and disagreed is noted for a candidate, it indicates that they agree and disagreed to parts of the question. 
Table 12.1: Comments from the Candidates to the Interview Questions

Does the candidate fundamentally agree or disagree with the premise of the questions?

\begin{tabular}{|c|c|c|c|c|}
\hline Question & Interviewee & Disagreed & Agreed & Comment \\
\hline \multirow{5}{*}{ 1/FU } & A & $x$ & $x$ & $\begin{array}{l}\text { but the true function must be first established and } \\
\text { properly represented }\end{array}$ \\
\hline & $\mathrm{B}$ & & $x$ & $\begin{array}{l}\text { but just because compliance to the PFR is objectively } \\
\text { measured does not render the choice of FS objective }\end{array}$ \\
\hline & C & & $\mathrm{x}$ & $\begin{array}{l}\text { but just because compliance to the PFR is objectively } \\
\text { measured does not render the choice of FS objective }\end{array}$ \\
\hline & $\mathrm{D}$ & & $x$ & $\begin{array}{l}\text { but just because compliance to the PFR is objectively } \\
\text { measured does not render the choice of FS objective }\end{array}$ \\
\hline & E & & $x$ & but concerned as to cost \\
\hline \multirow{5}{*}{$2 / \mathrm{MC}$} & A & & $x$ & but expert advice could also be taken \\
\hline & B & & $x$ & \\
\hline & C & & $x$ & but it might be unnecessary should answers be obvious \\
\hline & $\mathrm{D}$ & & $x$ & $\begin{array}{l}\text { but they would always want to try and achieve stakehol- } \\
\text { der input }\end{array}$ \\
\hline & E & & $x$ & $\begin{array}{l}\text { but concerned as to cost: could also be of high value for } \\
\text { use phase calculations }\end{array}$ \\
\hline \multirow{5}{*}{$3 / \mathrm{CoO}$} & A & $x$ & & $\begin{array}{l}\text { they do not believe the } \mathrm{CoO} \text { can be always accurately } \\
\text { identified }\end{array}$ \\
\hline & B & $x$ & $x$ & $\begin{array}{l}\text { they see } \mathrm{CoO} \text { being identified in some cases using } \\
\text { FUMCO but not in others }\end{array}$ \\
\hline & C & & $x$ & nice to have but not always necessary \\
\hline & $\mathrm{D}$ & & $x$ & \\
\hline & E & & $x$ & $\begin{array}{l}\text { if outer packaging changes between production to } \\
\text { consumption in countries which are not the } \mathrm{CoO}\end{array}$ \\
\hline \multirow{5}{*}{ 4/TRK } & A & & $x$ & $\begin{array}{l}\text { but they do not know how the LCA community can } \\
\text { address this issue }\end{array}$ \\
\hline & $\mathrm{B}$ & & $x$ & for all aspects of the LCA and not just manufacturing \\
\hline & C & $x$ & & $\begin{array}{l}\text { they do not see that it is always necessary or even } \\
\text { desired }\end{array}$ \\
\hline & $\mathrm{D}$ & & $x$ & they see it as imperative \\
\hline & $E$ & & $x$ & $\begin{array}{l}\text { if the technologically relevant knowledge does not exist, } \\
\text { it has to be made available }\end{array}$ \\
\hline
\end{tabular}

Pertinent points relating to the reflections of FUMCO by the interviewees, in chronological order, is listed below. 


\subsubsection{Expert Introductory Comments}

The interviewees typically made introductory comments prior to addressing the four FUMCO points. The major issue within these introductory points are listed below:

Interviewee $\mathbf{A}$ stated that the study addresses an important issue in LCA, confirming regular ignorance and even falsification in the world of LCA as well as product technological ignorance and LCA operatives that often do not know what a product is made of or how to address the challenge of finding out what a product is made of. Interviewee A do not see this as a technical problem nor that the solution to the problem would be addressed from a technical perspective.

Interviewee $\mathbf{B}$ stated that, based on personal experience of peer reviewing product LCA, they agree with the overall principle of the approach, stating that if an LCA is to be as accurate as it can be, there must be reliable detail on the data used in each stage of the study.

Interviewee $\mathbf{C}$ questioned the value of always having to carry out an LCA to achieve the goal of a study and that FUMCO would appear to be most useful in aiding product inventory collection in higher resolution categories.

Interviewee $\mathbf{D}$ stated that they saw value in trying to find a cost effective method of inventory data collection. Their central concern was cost and the need to understand if the cost of FUMCO was more than that of the traditional approaches to product inventory collection.

Interviewee $\mathbf{E}$ stated that the willingness of the LCA commissioning party to pay for a FUMCO approach could be a limiting factor. They thought it helpful to provide LCA practitioners with a tool kit on how to proceed with collecting product economic inventory data, in the absence of stakeholders, to gain high quality product data. While parts of the FUMCO approaches are already commonly used, it was seen as positive to provide a structured "and an entirely possible way" to collect product economic inventory data.

Conclusion: it can be concluded that there is general consensus amongst the interviewed experts that there are issues of accuracy in LCA. They answered that FUMCO could contribute to addressing this point; for one expert it was seen as potential "overkill" in that there will be many cases in which it will not be required, for another it was not seen as a solution as they did not believe a technical solution would resolve this LCA issue. Another expert stated that the approach to the collecting of product economic inventory in the absence of stakeholders requires to be structured and formalized.

The consensus is that it is an interesting research question. The fact that one candidate stated that the solution researched in the study is not the correct overall solution to challenges faced in the collection of product economic inventory data in the absence of 
stakeholder input is interesting. It may suggest another solution other than that proposed by the use of operatives with product technologically relevant knowledge and the instrument and expert approaches encompassed in FUMCO.

Other candidates were concerned with the costs associated with FUMCO compared to the cost of a non-FUMCO approach and the assumed costs of misrepresenting a product within a comparative LCA study.

\subsubsection{Expert Functional Unit based Comments}

As regards question 1. in the questionnaire above, the interviewees made the following points regarding the issue of $\mathrm{FU}$ :

Interviewee A stated the need to define the function of how the product is "normally used".

Interviewee B stated the need for the FU to be something that can be easily defined and that is not subjective. They also question who is to define what "too weak" is in order to set a PFR.

Interviewee C stated that one will never be able to achieve objectivity in choosing the category rule against which to compare. Category justification is the least robust part of a comparative study and is often conveniently set by an industrial sector to suit their objectives.

Interviewee D stated that the FU should consider why and for whom the study is being done, with a clearer definition of the scope and boundaries within the above explanation. They see this as a more challenging subject given that the objective is to compare products.

Interviewee $\mathbf{E}$ stated concern as to the cost of testing.

Conclusion: the conclusion that can be drawn is that while an objective measure of a FS defined in a PFR is helpful to contribute objectivity, the choice of the initial PFR and any associated quantifiable FS range will always be subjective choices. This topic of FU as relates to product comparisons was a point of major reflection by the majority of the experts.

\subsubsection{Expert Material Composition based Comments}

As regards question 2. in the questionnaire above, the interviewees made the following points regarding the issue of $\mathrm{MC}$ :

Interviewee $\mathbf{A}$ stated that there are indeed challenges regarding $\mathrm{MC}$ and significant efforts have to be made to identify the MC. Help can be sought from a laboratory (which they had used once); however, a short review of the relevant literature or discussions with a product expert can help in making a good estimate. 
Interviewee B stated that "in some ways" this is the area that is most likely to contain errors if the stakeholders are not involved. They further state that specific composition of materials is very difficult to assess unless data from the manufacturer is available, or a method such as FUMCO is available.

Interviewee C stated that this approach would be valuable to many different types of comparative LCA studies, although unnecessary for those studies in which an obvious conclusion is apparent up front.

Interviewee D stated they were in agreement regarding the FUMCO approach to material composition inventory data collection but they would always try to get the stakeholders to cooperate.

Interviewee E stated concern as to the cost of testing. They stated that the FUMCO approach could also be used in use-phase inventory analysis.

Conclusion: the conclusion is that there is general consensus amongst the experts that the accurate inventorying of product material composition is a challenge. They saw that FUMCO could contribute to improved material composition identification; this was also the case for the expert who did not see FUMCO method as an overall solution to increasing accuracy in LCA.

\subsubsection{Expert Country of Origin based Comments}

As regards question 3 . in the questionnaire above, the interviewees made the following points regarding the issue of $\mathrm{CoO}$ :

Interviewee A stated that they do not believe that this $\mathrm{CoO}$ issue is resolvable; commercial channels vary daily, so a laboratory test is no more than a measure within a moment in time. They state that some raw materials are subject to supply agreements in which surpluses and shortages are constantly being exchanged, requiring the use of regional or global averages.

Interviewee B stated concern regarding the supply chain complexity issue, as was the case for Interviewee A above, and emphasized the considerable value of knowing the CoO of a product, these two points driving the need for a method to identify the CoO. However, they questioned if the method of looking for origin information on packaging will always work.

Interviewee C stated again that this FUMCO approach to $\mathrm{CoO}$ is "nice to have" but is it always necessary? The issue is sensitivity: how sensitive would the inventory derived from the CoO energy source be on the conclusion of the study? 
Interviewee $\mathbf{D}$ stated they saw value in the use of a FUMCO approach to aid in identifying the $\mathrm{CoO}$ of a product.

Interviewee $\mathbf{E}$ stated that products might receive a new or an additional outer packaging on their way from production to consumption in countries which are not the CoO.

Conclusion: the conclusion is that there was more questioning as to whether FUMCO could always contribute to the accurate identification of $\mathrm{CoO}$ of a product due to the issue of long and variable supply chains.

\subsubsection{Expert Product Technologically Relevant Knowledge based Comments} As regards question 4. in the questionnaire above, the experts made the following points regarding the issue of product Technologically Relevant Knowledge (TRK):

Interviewee A stated that many LCA operatives have never been in a production plant and have little specific product knowledge. They do not see how this issue can be resolved.

Interviewee B stated they agree with what has been said on this subject in the questionnaire. They point out that it is also important to remember that insufficient technological knowledge could affect other life cycle stages as well as the 'manufacturing' phase that was highlighted in the questionnaire.

Interviewee C stated that product technologically relevant knowledge is an advantage and stated that LCA will likely move toward product sector specialism over time. However, they do not see this as being imperative and that being an LCA generalist is a specific skill in itself. The generalist's helicopter view may be of value to align the overall picture and relevances. They can then pursue the required specialists/knowledge themselves. Examples of erroneous assumptions and interpretation as regards technological relevance may relate to poor research.

Interviewee $\mathbf{D}$ stated that the use of technologically relevant operatives in making LCA is an obligation for them, as they are uniquely a sector specific LCA consultancy.

Interviewee $\mathbf{E}$ stated that if the technologically relevant knowledge does not exist, it must be made available within the respective LCA studies.

Conclusion: it can be stated that, in all cases, the advantage of LCA operatives having product TRK was seen as a benefit but not as imperative, except in the case of one expert who is a sector specific LCA operative and another who is an LCA generalist but insists access to product TRK is required. 


\subsubsection{An Overview of the Experts' Comments - Other Points of Interest}

1. Reference to stakeholders is still common amongst the experts' comments. All experts, with the exception of one, expressed that stakeholders are always involved. The expert that mentioned the lack of stakeholder expressed that they would still try and find the stakeholder even if a FUMCO approach was taken.

2. Reference to studies in previous literature and the seeking of product expert advice was regularly made, as was the case in the interviews in Chapter 5.

3. Reference was made to the point that product manufacturers themselves do not always know the exact composition of their product.

4. One expert stated that a laboratory approach cannot always identify the components from which to derive the product economic inventory data required.

5. The potential cost of FUMCO was regularly stated as a concern. Willingness of the LCA commissioning party to pay for a FUMCO approach could be a limiting factor.

6. One expert stated that the approach to the collecting of product economic inventory in the absence of stakeholders requires structuring and formalizing.

7. One expert stated their hope in the EU PEF development, referring to the very high quality standards placed upon product economic inventory data, or activity data, and that it will be highly assessed in PEF for quality.

8. One expert made reference to the importance of peer review but also mentioned that peer reviewers may also be devoid of product TRK.

9. Questions as to the general knowledge and experience of the LCA operative were combined with commentary regarding the product TRK, with statements as to the potential for an operative having TRK not necessarily needing FUMCO for their product inventory collection. One expert saw access to product TRK as imperative to a study.

10. Mention is made of the tendencies for LCA results to favour the specific material or process of the sponsor of the LCA, as well as LCA based on incorrect assumptions and product inventory data.

11. One expert stated that TRK should not just relate to the materials and conversion processes, stating that TRK be extended to also cover the end-of-life of a product. This should include the combination of the relevant knowledge of waste management options of the respective products in case of disposal as well as the current waste management situation in countries where the products are disposed. 
12. One expert stated that even if a material or processing type is selected correctly, there is still the risk of incorrect or questionable inventory data within the respective datasets, suggesting that at least a brief plausibility check of the dataset by product experts is additionally "recommended to prevent GIGO situations".

\subsubsection{Conclusions of the LCA Experts}

An overall conclusion would be that there is an issue with the quality and relevance of product economic inventory and assumptions in product LCA, due in part to the likely lack of product TRK of LCA operatives.

The role of FUMCO in MC analysis was the most agreed value of FUMCO, although it was stated that laboratory analysis cannot always identify and quantify all material components. In addition, the necessity for such analysis would be dependent on the resolution of the product category under study.

Value was seen in the measuring of FS where quantifiable but it was not seen to render the FU objective as the setting of PFR will always be subjective.

Questions were asked as to whether FUMCO could always accurately identify the CoO of a product given that product supply chains can be complicated.

The use of LCA operatives with product TRK was seen as helpful but not always necessary, as it may not be needed given a low resolution product category. It was also stated that the TRK may hamper the benefits of a "helicopter view", likely to be taken by the non-TRK operative.

While one expert believed FUMCO could be unnecessary, no expert stated that its use could reduce the quality or accuracy of product economic inventory compared to traditional inventory collection methods.

\subsubsection{Discussions in Response to the Comments of the LCA Experts}

Beyond those issues that the expert candidates raised that have been researched and addressed within this study, there are new issues for consideration and issues that have been expatiated by the experts that had only been briefly considered in the study.

Laboratories cannot provide all the answers: this is dependent on the nature of the products under study, in this case FSD. The nature of materials analytical instrumentation is such that it is doubtful that the correct qualification and quantification of the material components, which influence the ranking and rating of a product based on a comparative LCA, could not be identified.

This point was introduced by an expert who proposed the use of literature based research and discussions with product experts. They had also pointed out that a sample product assessment is only a moment-in-time situation. The question is if the literature is not 
perpetuating a previous error, or is accurate to the sample product, and whether the product expert can accurately identify the material composition of the sample product without instrumentation.

An example would be to give an FSD product to an expert and ask him to qualify and quantify the material components within the product. It may be difficult to imagine a situation in which the expert's judgement would be as accurate as an instrumental analysis of the product.

The question is does FUMCO return a more accurate qualitative and quantitative result of a moment-in-time study of a specific sample FSD than could be achieved from literature and expert opinion?

Cost: some reference is made to cost in the study but it was of significant concern to the experts. The question directly above this paragraph could be reformulated to read - what is the cost of applying a FUMCO method compared to researching previous literature and pursuing expert opinion?

The instrumentation needed to carry out the FUMCO approach requires an initial investment that would be more than for the tools required for the alternative approach to product economic inventory collection. This would be a mostly one time investment that is available for continual use at any moment in which an LCA operative requires a specific piece of inventory data.

Additionally, operatives with FSD product TRK and materials analysis experience may be more expensive than LCA operatives that are generalists. This point is not researched within the study.

It is possible that the largest cost to LCA of a product is the cost of the operative's time. If FUMCO could reduce the time spent on the collection of economic inventory data of the product, this benefit could be weighed against the upfront cost of the instrumentation needed to carry out the FUMCO approach.

If FUMCO improves the qualitative and quantitative accuracy of product economic inventory and therefore enhances the quality of the final LCA then this enhanced quality, and the associated benefits potentially deriving from it, could be compared to the cost of FUMCO.

LCA Operative Experience: this point was mentioned during the discussions about product TRK, as relates to knowing that the LCA operative has to search further and their knowing what to search for. Experience without knowledge may lead to the pursuit of the product TRK to address the issue. Already starting a study with product TRK may lead to a far more efficient collection of product economic inventory in terms of time and accuracy. 
Reference was made to the possibility that examples of erroneous assumptions and interpretation, as regards technological relevance, may relate to poor research. This could be derived from the issue of experience or the lack of product TRK.

LCA Operative Generalist: reference was made to the benefits of using an LCA operative who is a generalist rather than one with specific product TRK. It was stated that the generalist's helicopter view may be of value to get the overall picture and relevances aligned. They could then pursue the required specialists/knowledge themselves. It was further stated that they may be unencumbered by technical detail that may not necessarily be required.

The question here is if a FUMCO approach with product TRK renders the operative less able to take a helicopter view that may be of value to get the overall picture and relevances aligned. A further question is if a generalist approach is time/cost efficient and accurate, as regards product economic inventory collection, than would have been achieved taking the FUMCO approach with product TRK.

Stakeholders: there is a continual return to the subject of stakeholders by the experts, although the questionnaire specifically states that stakeholders are absent. They question the likelihood that stakeholders would be absent and request further research into situations of absent stakeholders.

These comments are rendered interesting when the same expert states that sometimes stakeholders do not know the material composition of their products.

Nice-to-Have vs Required: while the experts could generally see that a FUMCO approach could benefit the collection of product economic inventory, they did not feel it was always necessary and in one case felt that it did not resolve the overall problem of LCA accuracy.

Reference was made to the fact that some results of compared products may be evident up front and there would be no need for an LCA study and hence a FUMCO approach.

The question as to whether FUMCO is required or is simply a nice-to-have option could be dependent on the costs and accuracy of inventory derived from the FUMCO approach compared to the alternative.

Dataset Inventory: as relates to the above question of "the overall problem of LCA accuracy"; one example problem of LCA accuracy, as mentioned by an expert, was the risk of incorrect or questionable inventory data within the respective LCI datasets, such as those provided by Ecoinvent.

This point is important given that comparative product rankings were being made, it being necessary to assess if the difference in values between the results is not smaller than the 
accuracy of data, considering questions such as "How close are the figures?" and "How accurate is the input data?".

This study has not researched the quality of the inventory data within the common LCl datasets.

\subsection{Chapter 12 Conclusions}

The experts understand the presented issues. They identify uncertainties in a FUMCO approach but have no common critical opinion against its use. Experts see the added value of the developed method but are hesitant due to issues related to possible costs and the extent to which a laboratory approach can always identify all components, specifically questioning the ability for FUMCO to identify the $\mathrm{CoO}$ given the complexity of product supply chains.

Given that the collection of product economic inventory data can be relatively laborious and expensive to achieve, some LCA experts suggest that there is a place for a simpler and more superficial approach, giving a "helicopter view" approximate assessment of a product or category of products. Whilst there might possibly be a place for such preliminary studies, perhaps to identify priority areas where fully researched studies might be particularly beneficial, it must always be borne in mind that such studies can be unreliable, particularly as regards relative ranking of the LCA impacts of competing products available from the market. Of concern is that data from such studies could end up in future studies given that the experts referred to sourcing inventory data from previous studies.

It was indicated that it would be helpful to provide LCA practitioners with a tool kit on how to proceed with life cycle inventory in the absence of stakeholders to gain product inventory data, providing a structured approach to high quality product economic inventory data collection.

While the experts saw value in some or all parts of the FUMCO approach, it could be concluded that they did not find FUMCO to be the single "silver bullet" solution to product economic inventory collection for input to LCA or to the general issues of comparative LCA as presented.

The following Chapter 13 is the concluding chapter of this study. 
Chapter 13

Study Conclusions 


\subsection{Introduction}

The use of food service disposables (FSD) is growing. There are many reasons for this development, such as growth in consumption of food out of home, the growth in prepared food for later consumption, the increased use of food delivery services and vending, as well as the ever growing number of people travelling and the growth in use of Food Service as a source of free-time or entertainment activity.

Many companies that provide food and drinks, involving the use of FSD, feel the need to put an environmental claim on their item. To understand such a claim and to know if it is credible, insight is needed into the material specification and source or country of origin of the item. Both insights are hard to gain. FSD are derived from a variety of competing sources, made of a wide range of materials and composites, involving a multitude of conversion processes.

Many companies go even further and want to be the best in category so they can say that the FSD they offer has the lowest environmental impact. It is evident that to compare products it is important that the comparable products be of like functionality. A clear definition of functional unit for an FSD is required which goes further than just defining that the cup is needed to drink.

Some comparative Environmental Claim Statements (ECS) have been shown to be incorrect. They can influence consumption, with the associated impact on resources and emissions. ECS have a marketing value, and have shown to differentiate products from their competitors and provide a unique selling point.

Marketers want to make comparative claims that meet customer perception, and research shows that there exists a conflict between perception and technical reality as regards packaging and the environment (Van Dam, Y., 1996).

To develop a comparative claim, various stakeholders have to be involved to gather the required information about their FSD product. Research shows that this is not always possible. There are a large number of companies all over the world producing and offering FSD with all kinds of traders in between the producers and users. Actors in the supply chain, such as an FSD distributor or snack bar proprietor, are often unable to identify the producer or the country where the FSD comes from. As the products are from the same end market with the same functionality, many stakeholders are not prepared to cooperate in such a study. Stakeholders may not understand the request for cooperation or have the time or inclination to cooperate. Research shows that this stakeholder cooperation is not likely, requiring product information to be gathered in their absence.

This information regarding the comparable FSD product sources, materials and processes, needs to be applied to a method for accounting of their environmental impact. 
An appropriate method is Life Cycle Assessment (LCA), which is a method of accounting for environmental impacts associated with the life cycle of a product, considering all inputs from and outputs to the environment in the life cycle. LCA methodology is governed by a number of ISO standards and is the subject of many scientific papers.

While the methodology is heavily studied, there is little to be found in research as relates to product economic inventory, that being the product materials, processes and sources to be input into the LCA. There is little to be found as relates to how this inventory is to be collected, while there are rules stating that the inventory input to LCA must be accurate to the product.

Research identified that there are a number of LCAs, some even to support policy decisions, that contain inventory choices and assumptions that are incorrect and not relevant to the product. This inventory is then input to an LCA study and obviously it affects the output result of the study.

Research then shows that this erroneous inventory has been taken forward into later LCA studies, due to the practice of actively sourcing product economic inventory data from previous studies. This further shows the risks associated with publishing LCA studies that contain erroneous product economic inventory data.

The reasons cited in the research for this issue of erroneous inventory can relate to the lack of product technologically relevant knowledge. Other reasons cited by LCA experts is the lack of funding to carry out deeper product inventory research and the tendency to take certain inventory data as granted. While LCAs whose results are to be published require peer review, it is also cited that such peer reviewers themselves may not have this product technologically relevant knowledge.

The consequence of this erroneous inventory input to LCA, sometimes at a minor, punitive or unexpected level, is shown to influence the rating and subsequent ranking of a product in a comparative study of like functionality products.

While LCA is seen as an appropriate method to account for the environmental impact, there is concern as regards the product economic inventory input to the LCA, especially to an LCA used to make comparative assertions.

How to address these challenges, as regards product economic inventory used as LCA input for comparative ECS, has been researched in this study. 


\subsection{Findings of the Research}

The research in this study has led to a number of findings that are enumerated below:

1. FSD are often presented with ECS.

2. FSD are products of minimalistic fit-for-purpose design, using the minimum of resource for their single use function of providing the sanitary consumption of food and drink while on the move.

3. FSD are products of embodied environmental impacts; their use does not require electricity input, such as when using an electric kettle. Their function is relatively simple, compared to packaging items with additional functions like shelf-life extension. It could be said that they have a relatively simple life cycle compared to packaging or products with use-phase impacts.

4. FSD categories can be of a very high resolution in which all products look identical but for which non-visual material differences exists. Alternatively, FSD categories can be of a very low resolution in which all products look very different, being made of very different materials and composites, using very different conversion technologies, but all with the same like functionality.

5. ECS are statements, symbols or graphics that indicate an environmental aspect of a product.

6. It is possible to make comparative ECS of like functionality FSD.

7. The FSD market is large and growing, due to significant lifestyle factors that drive the preparation and/or consumption of food outside the home.

8. FSD are sold without a functional specification which means that they do not have to be fit-for-purpose.

9. FSD are manufactured from a range of materials, their resource consumption being significant and growing.

10. FSD are sourced globally, often with very complex supply chains.

11. FSD are subject to environmental pressure from consumers, the press and national governments.

12. ECS are often comparative, based on LCA studies, LCA being a tool with which to calculate the environmental impact based on product economic inventory input. 
13. LCA requires accurate and relevant input if its output is to be equally accurate and relevant, assuming an appropriate LCA methodology in between.

14. The relevant LCA ISO standards require accuracy as relates to this product economic inventory input data and consistency as regards the methods of collection of this data.

15. Meaningful LCA studies can be applied to FSD products but to do this robustly can be quite challenging.

16. FSD product economic inventory would seem best sourced from the product stakeholder themselves. Research shows that such stakeholders do not always cooperate in comparative studies and if they did, it is still possible that their input could be of questionable accuracy.

17. Current FSD product economic inventory collection approaches rely on retrieving product inventory data from previous studies, study of product literature, patents, articles, electronic and on-line databases, industrial bulletins, and direct industrial contacts, to name but a few.

18. Research shows that current FSD product economic inventory collection approaches are not a guarantee of correct product inventory LCA input data.

19. Comparative LCA studies can be found in which the function of the FSD being compared is not equivalent.

20. Research identifies LCA based claim instructions that stipulate equal functionality of the compared items but do not state how this should be addressed.

21. Research shows that quantification of compliance to a function can change the products within a category and hence can produce different outcomes in a comparative study. The design and performance standards required of a viable alternative product for a given purpose need to be carefully defined and consistently applied.

22. Research identifies LCA based claim instructions that stipulate the requirement for accurate materials, conversion processes, energies, transports and other product economic data, but do not state how their collection should be addressed.

23. Research identifies that details of the material composition of an FSD, its sourcing, transport and manufacturing processing, and of its likely treatment on disposal need to be reliably assessed.

24. Incorrect product economic inventory, as regards FSD, exist in numerous LCA studies. 
25. FSD products do not require to be supplied with an accompanying material specification. It would appear unlikely that such a specification would be entirely accurate, as many simple fit-for-purpose cost items, like FSD, are subject to heavy competition and hence would need creative materials formulations to support their income model. These formulations are part of the supplier's intellectual property.

26. Sometimes, this incorrect inventory is to a level that confirms the LCA operative is missing the technologically relevant knowledge as regards FSD materials and manufacturing.

27. Research indicates that current inventory collection methods are not leading to correct product economic inventory input to LCA studies. LCA studies often refer to material "choices". If an exact material is identified, then it is not a question of "choice".

28. Research shows that incorrect input correlates with incorrect output of an LCA study, regardless of which LCA associated methodologies are applied.

29. The exact material composition (MC) of an FSD can vary from evident primary material. As an example, a plastic part could contain minerals or voids.

30. The correct quantification and qualification of the MC in FSD is possible, using analytical techniques involving spectroscopy and other instrumentation based studies.

31. Such approaches are used by the criminal justice system to convict based on evidence that is "beyond reasonable doubt". This would suggest that this approach to materials identification is robust.

32. Simple methods used to aid in identifying $M C$ are not reliable. As an example, measuring density as an indicator of mineral filler in a plastic FSD can be misleading if the manufacturer has also added a foaming agent that then reduces the density back down to that of the original plastic.

33. For a specific sample product under study, the current inventory collection approach could never exactly confirm the material composition of the sample in hand, whereas this is achievable using the appropriate analytical instrumentation.

34. Research shows that these previously unidentified materials can have very different environmental impacts from any primary material that may have been identified using current MC inventory collection methods.

35. Differences in product economic inventory data, such as material compositions, between current inventory collection based data and instrument based inventory collection, can influence the rating and subsequent ranking of a product within an 
ECS based on comparative LCA. This can occur even if the primary material of the FSD product is known, as additives, copolymers, coatings, fillers, gases, pigments and other additions to the primary material can change the rating and ranking.

36. The identification of the material composition confirms the production processes that can be used to make the MC of the FSD. If a specific material component is not sighted then its process of addition to the primary material goes unnoticed.

37. The correlation of the sighted additive to its specific conversion process requires product technologically relevant knowledge.

38. Not all FSD products are marked with their CoO. It is possible that such a marking may not always be accurate, given the elaborate supply chains associated with FSD.

39. Research shows that a spectroscopic approach can be used to identify the source of a packaging item. Expert sourcing knowledge as regards the FSD sector is also a method for identification of FSD sources or $\mathrm{CoO}$.

40. Identifying the source of the manufacturing or $\mathrm{CoO}$ of the FSD is important in order to correlate the production processing energy demand with a local energy source, either an exact source, as may be known for the given producer, or a national energy source as can be identified due to the knowledge of the country of production.

41. The environmental impact of energy can vary considerably between countries, and these differences in processing energy environmental impact can influence the results of comparative LCA studies.

42. Identifying the source of the manufacturing or $\mathrm{CoO}$ of the FSD is important in order to identify the associated transport types and distances.

43. Differences in transport types and distances can influence the results of comparative LCA studies.

44. If the above three aspects, of functional unit, material composition and country of origin, are not correctly identified in a comparative study, the rating and subsequent ranking of a product may not be correctly reflected.

45. Research repeatedly confirmed the need for specific knowledge, especially product related technical knowledge, to address the challenges of erroneous FSD product economic inventory data.

46. The model used to derive comparative ranking of alternative products needs to be defined clearly and fully, and ideally agreed as appropriate by public authorities. 
These findings will then support the study of a method or approach to product economic inventory collection that is an improvement on the current approach to product inventory collection.

\subsection{The Primary Research}

The primary research identified the factors that need to be addressed in developing a method in accordance with the study central research. These factors are:

1. The qualification of a product to the category functionality rules in support of the study functional unit

2. Product material composition qualification and quantification, and process qualification

3. Product country of origin identification

This led to the identification of the need for product technologically relevant knowledge of the LCA operative to more efficiently focus the inventory collection and interpretation.

A method, referred to as FUMCO, was developed for the product economic inventory collection.

The testing part of the research then addressed the extent to which the use of the FUMCO method could derive a different result from current inventory identification methods and what were the sensitivities of a FUMCO method. Research was then performed to assess if FUMCO could potentially increase objectivity, and if this could lead to a more valid comparative product claim in the absence of stakeholder input.

Findings from the research were also shared with LCA experts active in the foremost LCA consultancies and in academia in order to get their expert opinion on the results of the research and the proposed FUMCO approach to inventory collection. The experts stated that FUMCO could aid in the collection of inventory data with some concern as to its ability to identify the $\mathrm{CoO}$; they also made no statement as to any negative value in a FUMCO approach.

\subsection{The FUMCO Method}

The FUMCO method is a method of product economic inventory collection using an analytical instrumentation approach, including the product technologically relevant knowledge, with which many of the challenges of current product economic inventory collection can be overcome. 
The FUMCO method can produce different results compared to the current methods of collecting product economic inventory. Research shows this to be the case for products across various FSD product categories.

FUMCO results in objective assessment of product functionality in comparison with a set product functionality rule (PFR), an accurate identification of product materials composition and an enhanced assessment of the likely $\mathrm{CoO}$ of a product.

FUMCO would not be destructive to the collection of product economic inventory data in itself nor in comparison with traditional methods of product inventory data collection.

FUMCO method addresses the three factors, of functional unit, material composition and country of origin, as follows:

\section{Functional unit}

In a comparative study of products of like functionality, compliance to the functionality needs to be proven. Functionality rules are set based on predefined functional specifications. Functionality testing for compliance to these rules can involve the use of physical and mechanical property testing instrumentation. Compliance to the rules can then be objectively measured.

\section{Material composition}

Using spectroscopy and instrument based analysis, whose results are interpreted using the appropriate technical knowledge, the FSD material composition can be accurately identified, both qualitatively and quantitatively. Associated converting and production processes can then also be identified due to the identification of the specific material components.

\section{Country of Origin}

The country of origin ( $\mathrm{CoO}$ ) identification guides choices in the energy type used, transport distances and vehicle types. $\mathrm{CoO}$ can be identified using product expert knowledge as regards sourcing and instrument based analytical techniques.

In all of the above three factors there is a requirement for product technologically relevant knowledge. This is an important factor in the FUMCO approach.

\subsection{Practical Limitations of FUMCO}

FUMCO can be used to objectively measure function that can be quantified for compliance to a PFR that will itself always be based on a subjective choice. It cannot deliver full objectivity to the establishment of the functional specification (FS) as regards the functional unit of an LCA. 
FUMCO would also not be able to address unmeasurable functional specifications that could be demanded of a product, such as its look, print and feel, as might be required of an upmarket FSD product.

There may be limitations as to the ability of analytical instrumentation to identify all material components used in the production of a product. This may not be the case for a relatively simple product such as an FSD in which the variety of material components and additives are well known and are typically available in spectra libraries, but this is not a guarantee.

Due to the complexity of the FSD supply chain, it is questioned if the FUMCO approach would always result in a correctly identified country of origin of a product. FUMCO CoO identification is highly dependent on up-to-date sample spectra, a library of which would need to be built and kept current by the LCA operative. Such spectra is not available from commercial sources like materials spectra libraries for Raman or FTIR spectroscopy.

While expert panels can identify the converter of many products, there is always a chance that a product from a new or obscure source could go unidentified. It is also possible that the supplier can be identified but that the product is available from two manufacturing plants belonging to the same manufacturer in two different countries.

Hence, the hypothesis that FUMCO could be used to identify $\mathrm{CoO}$ is only partially supported by the research in this study.

For both of the above cases, there may be a risk that a material or source could go unnoticed when using the FUMCO approach. However, FUMCO is more accurate in the identification of product economic inventory compared to the current method of inventory collection, as the research shows. Material composition inventory that is not identified by FUMCO would also not be identified by the current inventory collection approach.

It is also evident that the FUMCO approach could be combined with parts of the current inventory collection methods. Both approaches are not mutually exclusive.

Once the basic product economic inventory data has been identified, many of the challenges of an operative, using the current inventory collection method, are experienced. FUMCO can help identify a conversion process type through identification of specific material components. FUMCO can then identify the $\mathrm{CoO}$ of the product. The energy required to run the conversion process may be electrical and the country of the location of the conversion process may be identified, but can it always be assumed that the energy is from the average of the country's national grid? Current techniques of inventory collection may then be required, such as reading the identified converter's website for possible indication of their electricity source. 
FUMCO can aid in making eventual product dataset choices from libraries, such as Ecoinvent, especially a choice of specific material type, but there may always be identified data against which no dataset exists or which various versions of the dataset exist. FUMCO results may not always be directly comparable with existing datasets of the kind in the Ecoinvent library.

$\mathrm{LCl}$ data in common dataset libraries will not fully represent the inventory of the product in hand. Understanding the correlation between the two sets of data has not been a focus of this study, but it should be considered when making LCl data choices from these common dataset libraries in order to establish the degree to which the dataset data is representative of the FUMCO derived product economic inventory data.

Carefully researched studies may on occasion still contain errors in relation, for instance, to the $\mathrm{CoO}$ and processing of materials. It would seem reasonable that, when the conclusions of any study are published, the $\mathrm{CoO}$ and processing data used are identified. Where a supplier or manufacturer can convincingly demonstrate that data used for their product is in error, there should be an opportunity for correction.

\subsection{Further Observations Derived from the Research}

\subsubsection{Relevance of the Use of LCA to the Decision to be Made}

By starting with the identification of the decisions requiring to be addressed and determining the information needed to make the decisions, this will aid in understanding if LCA is the most relevant tool to address the decisions.

The decision required within this study is derived from the determination and demonstration of environmental preferability of a product. This may require the use of LCA with or without, all or parts of FUMCO depending on the sensitivity of the products being compared. Alternatively, it could be possible that parts of the FUMCO method itself could help to identify that there is or is not a need to perform an LCA.

It is also possible that the decisions can be made without the use of LCA. Alternatively, it could also be possible that the decision requires the use of LCA but the level of accuracy derived from a FUMCO approach is not required, as it does not change the rating and subsequent ranking of a category of comparative products compared to the current approach to economic inventory collection.

FUMCO could serve to provide additional information on which approach to take in order to arrive at the decision, thus having value at an early stage in the study process. 


\subsubsection{FUMCO Role in Establishing the Goal and Scope of an LCA}

The goal definition determines the intended use of the study and, by association, the type of analysis required to achieve the goal. The scope describes the system to be studied, the quantity of information to be collected and the associated level of detail and quality.

This reference to the level of detail at this preliminary stage may be subject to reconsideration at a later stage, if it is discovered that the sensitivity of the category of products being studied in a comparative LCA is high. It could be that FUMCO then contributes a greater range of inventory per product that permits a more robust defence of the differences.

Typically, product inventory collection is defined as the most costly and time consuming part of the LCA study process. FUMCO, or parts thereof, could be seen to speed up this stage of the LCA study process and improve the accuracy of the identified product composition. FUMCO could hence become part of the scoping process:

1. helping to efficiently identify the breadth and depth of information to be collected

2. acting as a feedback loop from inventory collection to scope definition

3. aiding in defining the boundaries, assumptions, limitations and the planning of the study

4. aiding in eliminating information that is irrelevant

FUMCO derived data at the scoping stage may help identify the inventory that most relates to the life cycle impact assessment (LCIA) methodology defined in the goal and scope.

In the 1999 SETAC report, it is cited that scoping must be addressed "before any data are collected". This is understandable given that the current non-FUMCO approach, with its cost and time implications, could be too cumbersome to be part of the scope process and may still risk overlooking inventory that, had it been known in advance, would have influenced the scope definition.

The scope definition of the study could include the requirement to carry out a FUMCO product inventory study as part of the scope and for its conclusions to be used to define the scope.

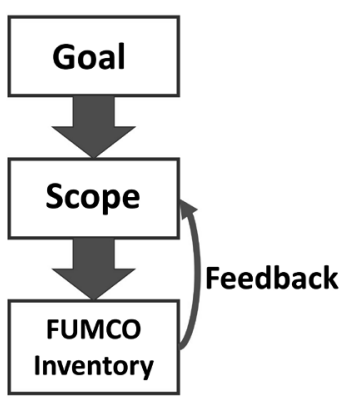

Figure 13.1: Feedback from FUMCO Inventory Identification to Enhance the Study Scope 
This study researches the life cycle impact of a product compared with other like functionality products. While function may be seen as obvious in a like product, there are cases in which it could require to be identified or measured using physical and mechanical analysis and testing as is part of FUMCO.

FUMCO could be valuable in defining the FU, specifically the FS required, the associated PFR and the compliance of a product to those rules. It is possible that defining the PFR has an influence on the scope, adding a further feedback loop.

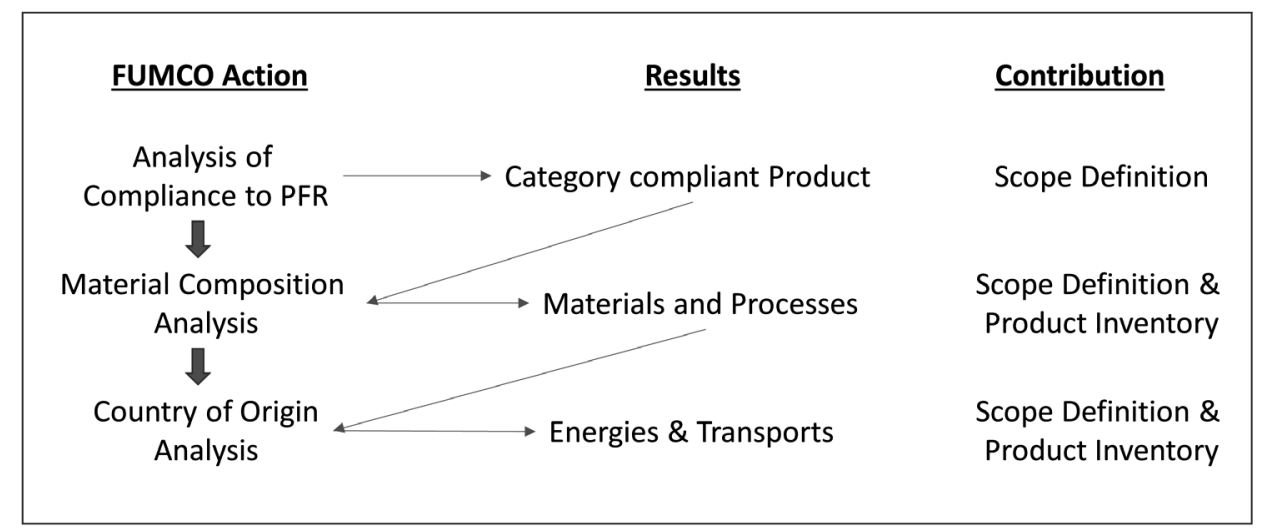

Figure 13.2: FUMCO Actions, Results and Contributions to Scope and Product Inventory Collection

\subsection{Value of the Study, and to Whom}

1. Society: at a time of exponential growth in population, increased resource scarcity and concerns regarding emissions and the climate, it would seem imperative to make every effort to increase the accuracy of ECS. Incorrect ECS may lead to consumers purchasing products that have a greater impact on the environment while believing they are making a correct choice.

The FUMCO method could aid in reducing the risk of incorrect product ECS, this being of value to society in general. It could also be that FUMCO could improve the quality of LCA against which national policy decisions are made, while possibly helping to more accurately account for any future carbon tax as might be required for a product.

If ECS are required by law to be justified by scientific research, as is the case in Denmark, then FUMCO could be of value in defending such research.

FUMCO could enhance product eco-innovation by improving the relevance and accuracy of comparative studies which guide specific product eco-innovations. 
There are numerous EU laws and Directives that make reference to the use of product LCA studies. FUMCO could help to further enhance the quality of the product inventory data used in such studies.

2. Science: given the number of scientific papers questioning the value of LCA and the number of published product LCAs with incorrect economic inventory choices and assumptions, FUMCO could contribute to making LCA more robust and defendable. Its efficiency may even lead to changes in the fundamental way the LCA approach is structured. It could be seen to introduce more objectivity into the LCA approach.

3. Commerce: if commerce were to see a greater accuracy and relevance in LCA, it may well be more willing to invest in LCA studies of its products. The FUMCO approach leads to specific product knowledgeable operatives communicating with actors from the same sector and knowledge group.

The FUMCO method may also be more efficient and hence permit a lower cost of comparative LCA studies while increasing the inventory data accuracy, all of which may lead to a greater degree of confidence of the potential customer of the LCA consultancy.

A commercial party may want to compare their products with that of a competitor who is not a cooperative stakeholder in the study. FUMCO may enhance the quality of the inventory data of the absent stakeholder product, compared to the current inventory collection method, to the satisfaction of the party.

Product technologically relevant knowledge may drive a new type of LCA consultancy, one that specializes in a specific product group.

\subsection{Contribution to Knowledge}

It may be that parties feel that the subject of this study is logically evident, i.e. that product economic inventory data collection methods need improving and product technological knowledge should be adopted. While there is critique that leads to the questioning of both, there is very little proposition as to a solution. The foremost documents researched related to LCA procedure do not inform LCA operatives as to how to collect the most accurate product inventory; they just require that it be accurate and subject to peer review, with reviewers being potentially no better informed than the author of the studies they are reviewing.

As such, it is hoped that this study will have contributed to knowledge and induce further questioning and research, as relates to the subject of product economic inventory collection methods and its effect on the quality of LCA. 
While this study proposes a method to collect product economic inventory, it does not seek to suggest that this is the only method, or that the method will work $100 \%$ of the time, or that all parts of the method have to be used together, or that the method has to be used at the exclusion of other methods, but that it is a method that could contribute to improving the product economic inventory collection process.

\subsection{Learnings regarding Environmental Claim Statements}

An ECS is a "Statement, symbol or graphic that indicates an environmental aspect of a product, a component, packaging or a service". ECS are claims that are required to be "legal, decent, honest, and truthful", of which the claim maker is required "to produce evidence as to the accuracy of factual claims they have made". These statements have been taken from the various laws and directives related to ECS.

ECS with context would seem to be the most relevant, i.e. those being based on studies of comparative products. An example of this is those ECS that could function to address the question "which one of these products has the lowest environmental impact", such as the EU Energy Label. This label can be found on all washing machines in a white goods store, helpfully directing the consumer to the better performing machines from an environmental perspective.

The question "which one of these products has the lowest environmental impact" indicates that a category of similar products is to be compared and that a quantifiable indicator is applied to each product so that comparisons can be made. This quantification can be found in the ISO standards related to environmental claims, notably Type III claims which are defined as "voluntary programs that provide quantified environmental data of a product, under pre-set categories of parameters set by a qualified third party and based on life cycle assessment, and verified by that or another qualified third party". Hence, quantification can be achieved based on life cycle assessment (LCA).

It would follow that ECS claims based on comparative LCA studies of products would necessarily be required to be correct in their conclusion to comply with the various laws, especially in countries where these laws are strictly enforced. They would also be required to comply with the need to prove accuracy of factual claims that have been made.

Returning to the question "which one of these products has the lowest environmental impact", it is evident that both the comparative category and the quantification need to be "legal, decent, honest, and truthful", be factual and prove accuracy. This would require the product to comply exactly with a functionality rule and to be proven to be functionally equivalent in order to prove comparability. Likewise, it would be required that the accuracy of any quantification had been proven. These two factors would then be subject to verification by a qualified third party. 
Taking a product group such as food service disposables (FSD), many ECS can be seen; however, most of these are Type II claims, notably "self-declared environmental claims that are made, without independent third party certification, by manufacturers, importers, distributors, retailers or anyone else likely to benefit from such a claim". To access comparative claims, it is necessary to access comparative LCA studies both from within scientific research and those in the public domain.

Research identified comparative LCA studies, as regards FSD, that included products whose functions were not comparable, whose material composition was erroneous and for which incorrect conversion processes were adopted. There are numerous studies with this issue, some from very reputable LCA consultancies, and some that are used to support public policy decisions.

Some of these errors are of a type that would indicate that the LCA operative is lacking in the relevant technical knowledge as regards the product. It is not that these errors are always of a type that would require an exceptional level of deep technical knowledge of the product. In fact, these errors are of the type that could be easily identified by manufacturers of the product.

If these three factors of function, material composition and conversion process were incorrect then, regardless of the LCA methodology or quality, there is a chance that some or all products will be incorrectly represented in a comparative product ECS.

It would appear that current methods for collection of product economic inventory, for input into an LCA study, can fall short; they are not always serving the goal of a legal, accurate and defendable comparative LCA study result. The use of stakeholders is referred to in interviews with LCA experts on the subject of inventory collection; however, research shows that stakeholders are often absent. There are also references to experts using the term "choices" as regards product economic inventory; it could be said that this term indicates that a number of materials could be chosen for a product. While the material composition of the product in hand will be very specific to that product, there is no choice.

Incorrect product economic inventory and lack of the relevant technical knowledge is reported in research. However, little suggestion as to how this might be resolved is provided.

If a party wished to make a comparative product Type III ECS based on LCA that was accurate and defendable, they would need to start by providing accurate product economic inventory input to the LCA methods and tools of their choice. Research shows the choice of LCIA methodology can influence results and this would need to be considered as regards a "legal, decent, honest, and truthful" outcome.

The focus in this study was on the collection of product economic inventory for input to LCA and not on the various LCA and LCIA methodology choices. It is assumed that the 
operative has made this choice; the reasons for this choice have not been studied. The accuracy of $\mathrm{LCl}$ data in common datasets was also not part of this study; it is assumed that an operative with product TRK would choose a dataset that they deem to be of sufficient quality.

\subsection{Environmental Claim Statements - Addressing the Issue of Product Economic Inventory Collection}

The reasons for the need of a party to have a comparative ECS have been briefly touched on in the study. In this case, it is assumed that the party requires an ECS and that it should comply to the relevant laws and directives. It is also assumed they have made the appropriate LCA methodology choices.

Subsequently, they need to collect the product economic inventory for input to LCA.

\subsubsection{Function}

After identifying the type of product to be studied, it is necessary to define its function as it is this function that will dictate if a product is compliant to the chosen product category. The chosen function is a subjective choice, but compliance to it can be objective if functionality can be quantitatively measured.

These quantitative measurements can be carried out using a variety of appropriate instrumentation and analytical techniques. Opinions as to which cup is stronger can be misleading, and horizontal compression tests of a cup containing the appropriate beverage type at a set volume and temperature can measure this strength and accurately return a quantitative result.

There are many types of functionality test methods. The appropriate tests should be identified, and the test results logged as a defence of the choices and exclusions in a comparative product category. While the choice of the product function under study is subjective, at least compliance to it can be objectively justified and defended.

A defendable product category, for comparison purposes, has been identified.

\subsubsection{Material Composition}

These products can be very similar to one another, a so-called product category of high resolution, or can be very diverse in their choice of shapes, sizes, weights, materials, etc., a so-called product category of low resolution. Regardless of the level of resolution, it should be that material composition (MC) is accurately identified. A significant amount of the environmental impact of an embodied impact product is associated with the materials, as regards the material itself and the conversion of that material to a final product. 
Research shows that MC identification is possible using the appropriate analytical instrumentation. While FSD are simple fit-for-purpose products, it is still important to accurately identify their materials using spectroscopy or similar analytical techniques. Simpler techniques, such as density measurement, cannot on their own identify MC. Examples of density being intentionally altered to hide other material components can be found.

This "forensic" type approach is used by the criminal justice service to convict offenders "beyond reasonable doubt". A list of the identified MC of the compliant category of like functionality products can then be logged as a defence of the MC product economic inventory data for LCA input.

Additionally, this MC identification would indicate the type of conversion processes that are required to manufacture a product of the identified $\mathrm{MC}$. As an example, the identification of a specific component, like the bioplastic PLA, would indicate that the product requires considerable drying before processing.

A list of the identified conversion processes of the materials in the products of the compliant category of like functionality products can then be logged as a defence of the conversion process product economic inventory data for LCA input.

As many of these processes require the use of energy, it then becomes important to identify the types of energy used.

\subsubsection{Country of Origin}

In relation to the conversion processes, country of origin $(\mathrm{CoO})$ identification may help identify the exact source and, if the source's website indicates their energy mix, could help in identifying the energy related impact of the conversion processes. Alternatively, it could help identify the energy impact given the national energy mix data, should the processes simply rely on the local energy sources. CoO identification would also generally indicate transport distances and types.

$\mathrm{CoO}$ is challenging. Spectroscopy can be used, as research shows; however, it requires considerable effort in terms of building and maintaining up-to-date spectra libraries of similar products. It also involves the use of experts with FSD sourcing knowledge. The mix of both approaches may provide the most accurate source identification, although it is possible that this identified source is not "beyond reasonable doubt".

This spectroscopic and expert approach could potentially benefit from some of the current inventory collection methods to further enhance the accuracy of any resultant CoO identification.

A list of the identified $\mathrm{CoO}$ and/or product sources of the products in the compliant category of like functionality products can then be logged as a defence of the $\mathrm{CoO}$ related product economic inventory data for LCA input. 


\subsubsection{The Environmental Claim Statement}

"Legal, decent, honest, and truthful" inventory data, of which the claim maker is required "to produce evidence as to the accuracy of factual claims they have made" is then available for inclusion into the LCA study. This inventory would thus be defendable to a peer review committee, assuming they have the product relevant technical knowledge.

\subsection{Environmental Claim Statements -Recommendations on How to Overcome Misleading ECS}

It is strange that examples continue to exist of LCA studies with incorrect inventory data, especially in light of the clear requirements of the law, directives, international standards, as well as concerns for the impact of misleading ECS to drive potentially incorrect consumer purchasing choices and public policy defence. Examples of the policing and legal actions against potentially erroneous claims are very few.

Laws do exist as relates to the making of environmental claims; these are often part of the requirements for truth in advertising, the advertising standards. These laws could be an adequate start to addressing this ECS issue and should be enforced.

Some FSD items are actually packaging items which are covered by the associated EU directive of packaging and packaging waste (94/62/EC). This directive requires the use of LCA to identify the environmental impact of a product, as do many other directives related to public procurement etc.

The packaging related directives should be enforced along with the advertising standards. Together this could initiate a process to improve ECS of comparative products.

The LCA community itself has numerous rules and standards, especially as relates to accuracy and credibility. The EU PEF development refers to product economic inventory, or activity data as it is known, being held up to a very high quality standard. Thus, it will be highly assessed for quality.

Research shows that these rules are not always policed and that the knowledge of those that do so, the peer reviewers, may be equally devoid of the relevant technical knowledge and hence unable to judge the validity of a material choice.

Research also shows that when a peer reviewer makes a recommendation as to the use of a correct material component, the LCA operative may choose to not adopt this correct material in their study as it has no consequence on the study result. If this incorrect material choice is adopted in a future study, it may have an effect on the result of that study. It may be valuable to insist that the correct material be adopted if the study is to be visible to third parties. 
It could be that an operative carrying out a specific product type LCA that concludes in a comparative ECS should have to be certified or mandated to carry out such a study, with both the product technologically relevant knowledge as well as the knowledge required to perform an LCA.

Alternatively, or jointly, it could be of value to ensure that all comparative product LCA studies destined for ECS are subject to peer review by a technical expert in the specific product sector as well as an expert in LCA.

Were FSD products to be legally required to publish or exhibit accurate material composition data and country of origin markings, this would be of value. This may prove difficult to enforce, both due to the complexity of the supply chain and the highly variable material compositions.

The impact of packaging on the environment is a matter for science and technology; it is not a matter of opinion. Unfortunately, opinion and perception seem to continue to play a significant role as regards commentary, press articles, draft government policies and ECS. The UNEP have reported that significant opportunity for environmental damage has been promoted by otherwise good intentioned people. This further shows that this is not a simple matter, but one requiring quite expert knowledge. It could be that a more general rule as regards commentary on this subject could be identified, a rule that removes this destructive behaviour, although this may be a rather idealistic statement.

\subsection{Recommendations for Future Research}

It would seem of importance to further address the issues and research within this study that could enhance product economic inventory collection. Research of this type, compared to the status-quo of the current traditional inventory collection approaches, would seem of value. This may be of particular importance if products are to be the focus of policy decisions based on comparative LCA studies.

The interview with experts indicated a desire to make available a structured and formalized approach to product economic inventory data collection in the absence of stakeholder cooperation; this would appear to be an interesting topic for further research. Alternative product economic inventory collection approaches do exist and should be further researched to enhance the relevance and value of comparative LCA.

Further research could lead to improvements in the generalization of the findings in this study. This further research could cover:

1. A larger sample study covering a range of non-FSD products of embodied environmental impact. What are the types of analytical instrumentation needed to cover the maximum number of differing product types, and are there any limitations? 
2. A study of the accuracy of instrumentation based identification of the country of origin of products.

3. A study as relates to the value of a FUMCO approach for packaging items in general given their additional functionality, such as product shelf-life extension.

4. A study of the timing and cost of the FUMCO method compared to the traditional method. Could the use of the FUMCO method lead to more efficient and lower costs LCA studies?

5. A study into the implications for ISO peer review and PEF if the FUMCO method was adopted as a form of additional control of sample product inventory.

6. A study of the types of collection methods that could be developed beyond those of the researched current methods and the proposed FUMCO method. A study that seeks to address the criticism of quality as is associated with LCA.

7. A study of the possibility of automating the economic inventory collection process using specifically designed instrumentation, algorithms and databases.

8. Research into the degree of objectivity that could reasonably be achieved when establishing product functionality rules and the functional unit of a comparative LCA study of product categories of high resolution.

9. Research into the feasibility of establishing a legal obligation to provide accurate product material composition and source information in support of LCA. What are the implications for trade and intellectual property?

10. Research into who should champion well researched future LCA studies of products, identifying the most relevant public bodies charged with addressing environmental protection. This could be at local, national, EU or fully international levels: "the wider the better".

11. This study has highlighted the deficiencies of traditional, or simply visual, approaches to product inventory collection and serves as a case study on the importance of thorough inventory research. There can be extreme cases of oversimplified environmental pressures, such as mantras to "ban all plastics". Research into the extent that incorrect inventory has influenced product choices would seem of importance.

12. The methodology applied in this research can of course be adopted in other areas. One possible type of exercise could be in design studies for a new consumer product. If the materials, production and end-of-life processes raise significant environmental issues, a study like the one used in this research could be used to compare the environmental 
impacts of different design choices. The role of FUMCO in product eco-innovation, as regards comparisons between products, could be a topic for further research. 


\section{References}

The following papers, in alphabetic order, are referenced in the text.

\section{Scientific References}

Andersson, T., \& Wesslén, B. (2003, May). Degradation of LDPE LLDPE and HDPE in film extrusion. In Proceedings of the 2003 TAPPI European PLACE Conference (Vol. 2, pp. 333-359). TAPPI Press.

Ashby, M. F. (2009). Materials and the environment: eco-informed material choice; 2009. ISBN 978-1-85617-608-8.

Ayres, R. U. (1995). Life cycle analysis: A critique. Resources, conservation and recycling, 14(3), 199-223.

Azapagic, A., \& Clift, R. (1999). Allocation of environmental burdens in co-product systems: productrelated burdens (Part 1). The international journal of life cycle assessment, 4(6), 357-369.

Bag, D. S., Nandan, B., Alam, S., Kandpal, L. D., \& Mathur, G. N. (2003). Density measurements of plastics-A simple standard test method.

Baitz, M., Albrecht, S., Brauner, E., Broadbent, C., Castellan, G., Conrath, P., ... \& Krinke, S. (2013). LCA's theory and practice: like ebony and ivory living in perfect harmony? The International Journal of Life Cycle Assessment, 1-9.

Baker, J. W., \& Lepech, M. D. (2009, September). Treatment of uncertainties in life cycle assessment. In Proceedings of the 10th international congress on structural safety and reliability, Osaka, Japan (pp. 13-17).

Bare, J. C., Hofstetter, P., Pennington, D. W., \& De Haes, H. A. U. (2000). Midpoints versus endpoints: the sacrifices and benefits. The International Journal of Life Cycle Assessment, 5(6), 319-326.

Baumann, H. (1998). Life cycle assessment and decision making: theories and practices. Chalmers University of Technology. LCA at Ericsson: A Beginning 1998b.

Baumann, H., \& Tillman, A. M. (2004). The Hitch Hiker's Guide to LCA. An orientation in life cycle assessment methodology and application.

Bengtsson, M., \& Steen, B. (2000). Weighting in LCA-approaches and applications. Environmental progress, 19(2), 101-109. 
Benjamin Gomes-Casseres. (1996). The alliance revolution: The new shape of business rivalry. Harvard University Press.

Bennett, N. D., Croke, B. F., Guariso, G., Guillaume, J. H., Hamilton, S. H., Jakeman, A. J., ... \& Pierce, S. A. (2013). Characterising performance of environmental models. Environmental Modelling \& Software, 40, 1-20.

Benson, S. J. (2012). Forensic Applications of Isotope Ratio Mass Spectrometry. Mass Spectrometry Handbook, 7, 341.

Berkel, R. van (2002, October). The application of life cycle assessment for improving the ecoefficiency of supply chains. In Proceedings of the Muresk 75th anniversary conference'. Available at http://muresk. curtin. edu. au/research/otherpublications/75thanniversary/ index. html [Verified 29 November 2007].

Bjørn, A., \& Richardson, K. (2015). Better, but good enough? Indicators for absolute environmental sustainability in a life cycle perspective.

Brandão, M., Heath, G., \& Cooper, J. (2012). What Can Meta-Analyses Tell Us About the Reliability of Life Cycle Assessment for Decision Support?. Journal of Industrial Ecology, 16(s1), S3-S7.

Bras-Klapwijk, R. M. (1999). Adjusting life cycle assessment methodology for use in public policy discourse. TU Delft, Delft University of Technology.

Broca, Mita. (2008). A comparative analysis of the environmental impacts of ceramic plates and biodegradable plates (made of corn starch) using Life Cycle Analysis. Department of Natural Resources TERI University. Retrieved from http://sustainability. tufts.edu/wp-content/ uploads/LifeCycleAnalysisPlasticPlatevsCeramic.pdf

Buysse, K., \& Verbeke, A. (2003). Proactive environmental strategies: A stakeholder management perspective. Strategic management journal, 24(5), 453-470.

Byron, D. J., \& Canto III, S. L. Post 4. 2013.

Camacho, W., \& Karlsson, S. (2001). NIR, DSC, and FTIR as quantitative methods for compositional analysis of blends of polymers obtained from recycled mixed plastic waste. Polymer Engineering \& Science, 41(9), 1626-1635.

Carter, J. F., Grundy, P. L., Hill, J. C., Ronan, N. C., Titterton, E. L., \& Sleeman, R. (2004). Forensic isotope ratio mass spectrometry of packaging tapes. Analyst, 129(12), 1206-1210.

Causin, V. (2010). Polymers on the crime scene: How can analytical chemistry help to exploit the information from these mute witnesses? Analytical Methods, 2(7), 792-804. 
Causin, V. (2015). Formulation: Polymer Matrix, Fillers, Dyes, Pigments and Other Additives. In Polymers on the Crime Scene (pp. 167-263). Springer International Publishing.

Cederstrand, P., Riise, E., \& Uihlein, A. (2014). Evaluation of recycling and allocation methods for paper. SCA, The Swedish Life Cycle Center report, (2014), 1.

Chesson, L. A., Tipple, B. J., Barnette, J. E., Cerling, T. E., \& Ehleringer, J. R. (2015). The potential for application of ink stable isotope analysis in questioned document examination. Science \& Justice, 55(1), 27-33.

Ciroth, A., Fleischer, G., \& Steinbach, J. (2004). Uncertainty calculation in life cycle assessments. The International Journal of Life Cycle Assessment, 9(4), 216-226.

Davids, K. (1996). Home Roasting Coffee: Romance and Revival. web page from Amazon. com with link to book, 1996, Publisher St. Martin's Press, US.

Delhoofen P.J.W.M., 1994. Handboek ontwerpen; Rijswijk: Stam Techniek.

Demmer, B. J. (2011). Comparison and analysis of biobased/biodegradable and petrochemical cutlery flexibility.

Denison, R. A. (1998a). Environmental Comparison of Reusable Ceramic Mugs vs. Disposable Cups Made from Polystyrene or Virgin Bleached Paperboard. The Alliance for Environmental Innovation.

Dirwono, W., Park, J. S., Agustin-Camacho, M. R., Kim, J., Park, H. M., Lee, Y., \& Lee, K. B. (2010). Application of micro-attenuated total reflectance FTIR spectroscopy in the forensic study of questioned documents involving red seal inks. Forensic Science International, 199(1), 6-8.

Dreyer, L. C., Niemann, A. L., \& Hauschild, M. Z. (2003). Comparison of three different LCIA methods: EDIP97, CML2001 and Eco-indicator 99. The International Journal of Life Cycle Assessment, 8(4), 191-200

Durocher, J. F. (1982). Disposables in food service. Cornell hotel and restaurant administration quarterly.

EC-JRC. 2010. International Reference Life Cycle Data System (ILCD) Handbook - General guide for Life Cycle Assessment - Detailed guidance. First edition March 2010. European Commission - Joint Research Centre - Institute for Environment and Sustainability. Publication office of European Union, Luxembourg.

Egan, C. (2001). US labeling program evaluation and label redesign strategies. The Regional. 
Eisenreich, N., \& Rohe, T. (2006). Infrared Spectroscopy in Analysis of Plastics Recycling. Encyclopedia of Analytical Chemistry: Applications, Theory and Instrumentation.

Ekvall, T., \& Finnveden, G. (2001). Allocation in ISO 14041-a critical review. Journal of cleaner production, 9(3), 197-208.

Ekvall, T., \& Tillman, A. M. (1997). Open-loop recycling: criteria for allocation procedures. The international journal of life cycle assessment, 2(3), 155-162.

Felix, C. W. (1990). Foodservice disposables and public health. Dairy, Food and Environmental Sanitation, 10(11), 656-660.

Finkbeiner, M. (2014). Product environmental footprint-breakthrough or breakdown for policy implementation of life cycle assessment. Int J Life Cycle Assess, 19(2), 266-271.

Finnveden, G. (1999). A critical review of operational valuation/weighting methods for life cycle assessment. preparation. På uppdrag av AFN vid Naturvårdsverket.

Finnveden, G., \& Ekvall, T. (1998). Life-cycle assessment as a decision-support tool-the case of recycling versus incineration of paper. Resources, conservation and recycling, 24(3), 235-256.

Finnveden, G., Hauschild, M. Z., Ekvall, T., Guinée, J., Heijungs, R., Hellweg, S., ... \& Suh, S. (2009). Recent developments in life cycle assessment. Journal of environmental management, 91(1), 1-21.

Fisher L.E. (2008). Signaling Change Studying the effect of price signals on disposable hot beverage cup consumption, Tufts University, 2008

Fitter, R. (2001). Who Gains from Product Rents as the Coffee Market Becomes More Differentiated? A Value-chain Analysis. IDS bulletin, 32(3), 69-82.

Franklin (2006): Life cycle Inventory of Polystyrene Foam bleached Paperboard, and Cor-rugated Paperboard Foodservice Products; prepared for THE POLYSTYRENE PACKAGING COUNCIL by Franklin Associates; Prairie Village, Kansas, USA.

Galarraga Gallastegui, I. (2002). The use of eco-labels: a review of the literature. European Environment, 12(6), 316-331.

Garrido, N., \& Del Castillo, M. D. A. (2007). Environmental evaluation of single-use and reusable cups. The International Journal of Life Cycle Assessment, 12(4), 252-256.

Garton, A., Infrared Spectroscopy of Polymer Blends, Composites and Surfaces, Hanser Publishers, New York, 1992. 
Gaussin, M., Hu, G., Abolghasem, S., Basu, S., Shankar, M. R., \& Bidanda, B. (2013). Assessing the environmental footprint of manufactured products: A survey of current literature. International Journal of Production Economics, 146(2), 515-523.

Gehlhar, M., \& Regmi, A. (2005) p5. Factors shaping global food markets. New directions in global food markets, 5-17.

Geisler, G., Hellweg, S., \& Hungerbühler, K. (2005). Uncertainty analysis in life cycle assessment (LCA): case study on plant-protection products and implications for decision making (9 pp+ 3 pp). The International Journal of Life Cycle Assessment, 10(3), 184-192.

Gentile, N., Siegwolf, R. T., Esseiva, P., Doyle, S., Zollinger, K., \& Delémont, O. (2015). Isotope ratio mass spectrometry as a tool for source inference in forensic science: A critical review. Forensic science international, 251, 139-158.

Gobet, F. (2015). Understanding Expertise: A Multi-Disciplinary Approach. Palgrave Macmillan.

Goedkoop, M., Heijungs, R., Huijbregts, M., De Schryver, A., Struijs, J., \& Van Zelm, R. (2009). ReCiPe 2008. A life cycle impact assessment method which comprises harmonised category indicators at the midpoint and the endpoint level, 1.

Goedkoop, M., Spriensma, R.: The Ecoindicator 99 - A damage oriented method for Life Cycle Impact Assessment, Methodology Report, 2nd edition, 17 April 2000, Amersfoort.

Guinée, J. B. (2002). Handbook on life cycle assessment operational guide to the ISO standards. The international journal of life cycle assessment, 7(5), 311-313.

Guinée, J. B., \& Heijungs, R. (2011). Life cycle sustainability analysis. Journal of Industrial Ecology, 15(5), 656-658.

Guinée, J. B., De Haes, H. U., \& Huppes, G. (1993). Quantitative life cycle assessment of products: 1: Goal definition and inventory. Journal of Cleaner Production, 1(1), 3-13.

Guinée, J. B., Gorrée, M., Heijungs, R., Huppes, G., Kleijn, R., Koning, A., .. \& Bruijn, H. (2002). Operational guide to the ISO standards. I: LCA in perspective. Ila: Guide. Ilb: Operational annex. III: Scientific background. Handbook on Life Cycle Assessment., 692.

Guinée, J. B., Heijungs, R., Huppes, G., Zamagni, A., Masoni, P., Buonamici, R., ... \& Rydberg, T. (2010). Life cycle assessment: past, present, and future.

Gulmine, J. V., Janissek, P. R., Heise, H. M., \& Akcelrud, L. (2002). Polyethylene characterization by FTIR. Polymer Testing, 21(5), 557-563. 
Habersatter, K., \& Widmer, F. (1991). Ecobalance of packaging materials. BUWAL Environmental Series, (132).

Häkkinen, T., \& Vares, S. (2010). Environmental impacts of disposable cups with special focus on the effect of material choices and end of life. Journal of Cleaner Production, 18(14), 1458-1463. http://doi.org/10.1016/j.jclepro.2010.05.005

Haq, G., \& Weiss, M. (2016). CO 2 labelling of passenger cars in Europe: Status, challenges, and future prospects. Energy Policy, 95, 324-335.

Harst, E. van der, \& Potting, J. (2013). A critical comparison of ten disposable cup LCAs. Environmental impact assessment review, 43, 86-96.

Harst-Wintraecken, E. J. Van der (2015). Robustness of life cycle assessment results: influence of data variation and modelling choices on results for beverage packaging materials. Wageningen University.

Hauschild, M. Z., Goedkoop, M., Guinée, J., Heijungs, R., Huijbregts, M., Jolliet, O., ... \& Sala, S. (2013). Identifying best existing practice for characterization modeling in life cycle impact assessment. The International Journal of Life Cycle Assessment, 18(3), 683-697.

Heijungs, R., \& Huijbregts, M. A. (2004, June). A review of approaches to treat uncertainty in LCA. In Proceedings of the IEMSS conference, Osnabruck.

Heijungs, R., Guinée, J. B., Huppes, G., Lankreijer, R. M., Udo de Haes, H. A., Wegener Sleeswijk, A., ... \& De Goede, H. P. (1992). Environmental life cycle assessment of products: guide and backgrounds (part 1).

Hocking, M. B. (1991). Relative merits of polystyrene foam and paper in hot drink cups: Implications for packaging. Environmental Management, 15(6), 731-747.

Hocking, MA. (1994a). Hocking 1994 - Disposable cups have eco merit. Nature, 369 (6476), 107. http://doi.org/http://dx.doi.org.proxy-remote.galib.uga.edu/10.1038/369107a0

Hocking, MA. (1994b). Reusable and disposable cups: An energy-based evaluation. Environmental Management, 18(6), 889-899. Retrieved from http://link.springer.com.proxy-remote.galib. uga.edu/article/10.1007/BF02393618

Hocking, MA. (1994c). Reusable vs. Disposable Cups. Retrieved April 30, 2016, from http://sustainability.tufts.edu/wp-content/uploads/Comparativelifecyclecosts.pdf 
Horacek, M., Min, J. S., Heo, S., Park, J., \& Papesch, W. (2008). The application of isotope ratio mass spectrometry for discrimination and comparison of adhesive tapes. Rapid Communications in Mass Spectrometry, 22(11), 1763-1766.

Horne, R. E. (2009). Limits to labels: The role of eco-labels in the assessment of product sustainability and routes to sustainable consumption. International Journal of Consumer Studies, 33(2), 175-182.

Hou, Q., Mao, G., Zhao, L., Du, H., \& Zuo, J. (2015). Mapping the scientific research on life cycle assessment: a bibliometric analysis. The International Journal of Life Cycle Assessment, 20(4), 541-555.

Huppes, G., van Oers, L., Pretato, U., \& Pennington, D. W. (2012). Weighting environmental effects: analytic survey with operational evaluation methods and a meta-method. The International Journal of Life Cycle Assessment, 17(7), 876-891.

Idoine, F. A., Carter, J. F., \& Sleeman, R. (2005). Bulk and compound-specific isotopic characterisation of illicit heroin and cling film. Rapid communications in mass spectrometry, 19(22), 3207-3215.

Ingwersen, W. W., \& Stevenson, M. J. (2012). Can we compare the environmental performance of this product to that one? An update on the development of product category rules and future challenges toward alignment. Journal of Cleaner Production, 24, 102-108.

Ingwersen, W., Subramanian, V., Schenck, R., Bushi, L., Costello, A., Draucker, L., ... \& Ryding, S. O. (2012). Product category rules alignment workshop, October 4, 2011 in Chicago, IL, USA. The International Journal of Life Cycle Assessment, 17(2), 258-263.

Jakeman, A. J., Letcher, R. A., \& Norton, J. P. (2006). Ten iterative steps in development and evaluation of environmental models. Environmental Modelling \& Software, 21(5), 602-614.

Jansen R (2000) Weggooien of spoelen? Milieuvergelijking van eenmalige en meermalige kunststof glazen, gebruikt op evenementen, 3-20 .

Jenkins, R., X-Ray Fluorescence Spectrometry, 2nd Edition, Joch Wiley and Sons, New York, 1999.

Jiménez-González, C., Kim, S., \& Overcash, M. R. (2000). Methodology for developing gate-to-gate life cycle inventory information. The International Journal of Life Cycle Assessment, 5(3), 153-159.

Jishi, Sarah, Krupp, Corinne, \& Rowe, Sean. (2013). Compostable Utensil Evaluation and Feasibility Report for Humboldt State University. Report for Humboldt State University. Retrieved from http://www2.humboldt.edu/sustainability/sites/default/ files/envs410_121213-3.pdf 8 
Jolliet, O., Margni, M., Charles, R., Humbert, S., Payet, J., Rebitzer, G., \& Rosenbaum, R. (2003). IMPACT 2002+: a new life cycle impact assessment methodology. The International Journal of Life Cycle Assessment, 8(6), 324.

Jones, K., Benson, S., \& Roux, C. (2013). The forensic analysis of office paper using carbon isotope ratio mass spectrometry-Part 1: Understanding the background population and homogeneity of paper for the comparison and discrimination of samples. Forensic science international, 231(1), 354-363.

Ju, S., \& Chang, H. (2014). Consumer perceptions on sustainable practices implemented in foodservice organizations in Korea. Nutrition Research and Practice, 9.

Kalbar, P. P., Birkved, M., Nygaard, S. E., \& Hauschild, M. (2017). Weighting and Aggregation in Life Cycle Assessment: Do Present Aggregated Single Scores Provide Correct Decision Support?. Journal of Industrial Ecology, 21(6), 1591-1600.

Klick J, Wright JD. Grocery Bag Bans and Foodborne Illness. University of Pennsylvania Law School Institute for Law \& Economics Research Paper No 13-2. 2013.

Klooster, R. ten. A methodical approach to packaging design, 2002, Delft University Press.

Klöpffer, W. (2006). The role of SETAC in the development of LCA. The International Journal of Life Cycle Assessment, 11, 116-122.

Klöpffer, W., \& Grahl, B. (2014). Life Cycle Assessment (LCA): A Guide to Best Practice. Joch Wiley \& Sons.

Klöpffer, W., Curran, M. A., Frankl, P., Heijungs, R., Köhler, A., \& Olsen, S. I. (2007). Nanotechnology and life cycle assessment. A systems approach to nanotechnology and the environment: Synthesis of results obtained at a workshop Washington, DC 2-3 October 2006. European Commission, DG Research, jointly with the Woodrow Wilson International Center for Scholars.

Larson, J., \& Farkas, D. K. (2011, October). Indicating Impact: The Environmental Life-Cycle Rating Label. In Professional Communication Conference (IPCC), 2011 IEEE International (pp. 1-14).

Laurent, A., Olsen, S. I., \& Hauschild, M. Z. (2012). Limitations of carbon footprint as indicator of environmental sustainability. Environmental science \& technology, 46(7), 4100-4108.

Lavallée, S., \& Plouffe, S. (2004). The ecolabel and sustainable development. The International Journal of Life Cycle Assessment, 9(6), 349-354. 
Lazarevic, D. (2015). The legitimacy of life cycle assessment in the waste management sector. The International Journal of Life Cycle Assessment, 1-14.

Lee, S. G., \& Xu, X. (2005). Design for the environment: life cycle assessment and sustainable packaging issues. International Journal of Environmental Technology and Management, 5(1), 14-41.

Lee, T. J., Yoon, C., \& Ryu, J. Y. (2017). A New Potential Paper Resource; Recyclability of Paper Cups coated with Water-soluble Polyacrylate-based Polymer. NORDIC PULP \& PAPER RESEARCH JOURNAL, 32(1), 155-161.

Leng, Y. (2009). Materials characterization: introduction to microscopic and spectroscopic methods. Joch Wiley \& Sons.

Ligthart, T. N., \& Ansems, A. M. M. (2007). Single use cups or reusable (coffee) drinking systems: an environmental comparison. Netherlands Organization for Applied and Scientific Research, TNO Report, (2006-A), R0246.

Ligthart, T. N., \& Ansems, T. A. M. M. (2012). Modelling of recycling in LCA, Post-consumer waste recycling and optimal production, Prof. Enri Damanhuri (Ed.), ISBN: 978-953-51-0632-6, InTech.

Lorenzetti, L. R., \& Lorenzetti, D. (2000). Birth of coffee. Clarkson Potter.

Lutters, D., \& Klooster, R. ten (2008). Functional requirement specification in the packaging development chain. CIRP Annals, 57 (1), pp. 145-148. ISSN 0007-8506.

Magnier, L., \& Schoormans, J. (2017). How Do Packaging Material, Colour and Environmental Claim Influence Package, Brand and Product Evaluations? Packaging Technology and Science, 30(11), pp. 735-751.

Mans, C., Hanning, S., Simons, C., Wegner, A., Janßen, A., \& Kreyenschmidt, M. (2007). Development of suitable plastic standards for X-ray fluorescence analysis. Spectrochimica Acta Part B: Atomic Spectroscopy, 62(2), 116-122.

Markandya, A. (1997). Eco-labelling: An introduction and review. In Eco-labelling and international trade (pp. 1-20). Palgrave Macmillan UK.

Merricks, P., \& Jones, P. (1994). Designing control systems. The management of foodservice opera.

Merugula, L. (2013). Supporting Sustainable Markets Through Life Cycle Assessment: Evaluating emerging technologies, incorporating uncertainty and the consumer perspective. The Ohio State University. 
Merugula, L., \& Bakshi, B. R. (2014). Supplemental Information: Reusable vs. Disposable Cups Revisited: Guidance in life cycle comparisons addressing scenario, model, and parameter uncertainties for the U.S. consumer. The Ohio State University.

Minneti, J. J. (2010). Relational Integrity Regulation: Nudging Consumers Toward Products Bearing Valid Environmental Marketing Claims. Envtl. L., 40, 1327.

Morris, J. (1997). Green goods?: consumers, product labels and the environment. London, UK: IEA Environment Unit.

Mothé, C. G., \& de Miranda, I. C. (2009). Characterization of sugarcane and coconut fibers by thermal analysis and FTIR. Journal of Thermal Analysis and Calorimetry, 97(2), 661-665.

Nagarajan, V., Mohanty, A. K., \& Misra, M. (2016). Perspective on polylactic acid (PLA) based sustainable materials for durable applications: Focus on tougchess and heat resistance. ACS Sustainable Chemistry \& Engineering, 4(6), 2899-2916.

Nakano, K., \& Nakamura, T. (2003). Preparation of calibrating standards for x-ray fluorescence spectrometry of trace metals in plastics. X-Ray Spectrometry: An International Journal, 32(6), 452-457.

Naska A, Katsoulis M, Orfanos P, Lachat C, Gedrich K, Rodrigues SS, et al. Eating out is different from eating at home among individuals who occasionally eat out. A cross-sectional study among middle-aged adults from eleven European countries. Br J Nutr. 2015;113(12):1951-64.

Newell, S. A., \& Field, F. R. (1998). Explicit accounting methods for recycling in LCl. Resources, Conservation and Recycling, 22(1), 31-45.

Nikolaou, I. E., \& Tsalis, T. (2018). A framework to evaluate eco-and social-labels for designing a sustainability consumption label to measure strong sustainability impact of firms/products. Journal of Cleaner Production, 182, 105-113.

Notten, P., \& Petrie, J. (2003, October). An integrated approach to uncertainty assessment in LCA. In International Workshop on LCl-quality (Vol. 6).

Olsson, A., Petterson, M., \& Jönson, G. (2004). Packaging demands in the food service industry. Food Service Technology, 4(3), 97-105.

O’Neill, T. J. (2003). Life cycle assessment and environmental impact of polymeric products (Vol. 13). iSmithers Rapra Publishing.

Owens, J. W. (1997). Life-cycle assessment: Constraints on moving from inventory to impact assessment. Journal of industrial ecology, 1(1), 37-49. 
Pavithra, R., Gunasekaran, S., Sailatha, E., \& Kamatchi, S. (2015). Investigations on Paper Making Raw Materials and Determination of Paper Quality by FTIR-UATR and UV-Vis DRS Spectroscopy. International Journal of Current Research and Academic Review, 3(11), 42-59.

Payne-Palacio, J. 2009 (Payne-Palacio, J., \& Theis, M. (2009). Introduction to foodservice. Pearson/ Prentice Hall).

Peereboom, E. C., Kleijn, R., Lemkowitz, S., \& Lundie, S. (1998). Influence of Inventory Data Sets on Life-Cycle Assessment Results: A Case Study on PVC. Journal of Industrial Ecology, 2(3), 109-130.

Peters, G. P., \& Hertwich, E. G. (2006). The importance of imports for household environmental impacts. Journal of Industrial Ecology, 10(3), 89-109.

Poortinga W, Whitmarsh L, Suffolk C. The introduction of a single-use carrier bag charge in Wales: Attitude change and behavioural spillover effects. Journal of Environmental Psychology. 2013;36:240-7.

Potting, J., \& van der Harst, E. (2014). Facility arrangements, food safety, and the environmental performance of disposable and reusable cups. In Proceedings of the 9th International Conference LCA of Food (pp. 8-10). Retrieved from http://Icacenter.org/lcafood2014/ papers/32.pdf

Power, K., \& Mont, O. (2010, October). Dispelling the myths about consumption behaviour. In Knowledge Collaboration \& Learning for Sustainable Innovation: 14th European Roundtable on Sustainable Consumption and Production (ERSCP) conference and the 6th Environmental Management for Sustainable Universities (EMSU) conference, Delft, The Netherlands, October 25-29, 2010. Delft University of Technology; The Hague University of Applied Sciences; TNO.

Pro Carton http://www.procarton.com/wp-content/uploads/2014/08/glossaryenglish.pdf: Zakboek Verpakkingen, Klooster R. ten (2008), Handbook of Paper and Board, Holik H. 2013.

Razza, F., Fieschi, M., Innocenti, F. D., \& Bastioli, C. (2009). Compostable cutlery and waste management: An LCA approach. Waste Management, 29(4), 1424-1433. http://doi. org/10.1016/j.wasman.2008.08.021.

Reap, J., Roman, F., Duncan, S., \& Bras, B. (2008). A survey of unresolved problems in life cycle assessment. The International Journal of Life Cycle Assessment, 13(5), 374.

Rebitzer, G., Ekvall, T., Frischknecht, R., Hunkeler, D., Norris, G., Rydberg, T., ... \& Pennington, D. W. (2004). Life cycle assessment: Part 1: Framework, goal and scope definition, inventory analysis, and applications. Environment international, 30(5), 701-720. 
Rebitzer, G., Ekvall, T., Frischknecht, R., Hunkeler, D., Norris, G., Rydberg, T., ... \& Pennington, D. W. (2004). Life cycle assessment: Part 1: Framework, goal and scope definition, inventory analysis, and applications. Environment international, 30(5), 701-720, p. 707.

Riise, B. L., Biddle, M. B., \& Fisher, M. M. (2000). X-ray fluorescence spectroscopy in plastic recycling. American Plastics Council, APC/MBA Polymer Project.

Rogers, E., \& Kostigen, T. M. (2007). The green book: The everyday guide to saving the planet one simple step at a time. Harmony.

Rubik, F., Scheer, D., \& Iraldo, F. (2008). Eco-labelling and product development: potentials and experiences. International journal of product development, 6(3-4), 393-419.

Russell, A., Ekvall, T., \& Baumann, H. (2005). Life cycle assessment-introduction and overview. Journal of Cleaner Production, 13(13), 1207-1210.

Sammer, K., \& Wüstenhagen, R. (2006). The influence of eco-labelling on consumer behaviourResults of a discrete choice analysis for washing machines. Business Strategy and the Environment, 15(3), 185-199.

Sawyer, L., Grubb, D. T., \& Meyers, G. F. (2008). Polymer microscopy. Springer Science \& Business Media.

Schlosser, E. (2012). Fast food nation: The dark side of the all-American meal. Houghton Mifflin Harcourt.

Schmidt, H. J. (2009). Carbon footprinting, labelling and life cycle assessment. The International Journal of Life Cycle Assessment, 14(1), 6-9.

Schmincke, Posler (2001): Using LCA results in green marketing - a case study, in LCM 2001 Abstract Book, 1st International Conference on Life Cycle Management, Copenhagen, Denmark.

Sharp A, Høj S, Wheeler M. Proscription and its impact on anti-consumption behaviour and attitudes: the case of plastic bags. Journal of Consumer Behaviour. 2010;9(6):470-84.

Shrikanth, R., \& Raju, D. S. N. (2012). Contemporary green marketing-brief reference to Indian scenario. International journal of social sciences \& interdisciplinary research, 1(1), 26-39.

Sinclair R. G., Feliz A, Patel J, Perry C. The spread of a norovirus surrogate via reusable grocery bags in a grocery supermarket. J Environ Health. 2018;80(10):8-14. 
Sinclair R. G., Gerba CP, Sifuemtes LY, Tsai M, Abd-Bmaksoud S. Efficacy of Treatment of reusable grocery bags with antimicrobial silver to reduce enteric bacteria Food Prot Trends. 2016;38(8):458-84.

Singh, R., Singh, S., Trimukhe, K. D., Pandare, K. V., Bastawade, K. B., Gokhale, D. V., \& Varma, A. J. (2005). Lignin-carbohydrate complexes from sugarcane bagasse: Preparation, purification, and characterization. Carbohydrate polymers, 62(1), 57-66.

Sluisveld, M. A., van, \& Worrell, E. (2013). The paradox of packaging optimization-a characterization of packaging source reduction in the Netherlands. Resources, Conservation and Recycling, 73, 133-142.

Smith, L. P., Ng, S. W., \& Popkin, B. M. (2013). Trends in US home food preparation and consumption: analysis of national nutrition surveys and time use studies from 1965-1966 to 2007-2008. Nutrition Journal, 12(1), 1.

Sonnemann, G., Vigon, B., Broadbent, C., Curran, M. A., Finkbeiner, M., Frischknecht, R., ... \& Wang, H. (2011). Process on "global guidance for LCA databases". The International Journal of Life Cycle Assessment, 16(1), 95-97.

Stascak, J. (2017). Strike Out Paper Cups.

Straka, T. J., \& Layton, P. A. (2010). Natural resources management: Life cycle assessment and forest certification and sustainability issues. Sustainability, 2(2), 604-623.

Su, S. B., Lin, C. Y., Sheu, M. J., Kan, W. C., Wang, H. Y., \& Guo, H. R. (2010). Decrease in seroprevalence of Hepatitis $\mathrm{A}$ after the implementation of nationwide disposable tableware use in Taiwan. BMC public health, 10(1), 1.

Subramanian, V., Ingwersen, W., Hensler, C., \& Collie, H. (2012). Comparing product category rules from different programs: learned outcomes towards global alignment. The International Journal of Life Cycle Assessment, 17(7), 892-903.

Sujan, Mita, and Christine Dekleva. «Product categorization and inference making: Some implications for comparative advertising.» Journal of Consumer Research (1987): 372-378.

Taylor, E., Carter, J. F., Hill, J. C., Morton, C., Daeid, N. N., \& Sleeman, R. (2008). Stable isotope ratio mass spectrometry and physical comparison for the forensic examination of grip-seal plastic bags. Forensic science international, 177(2), 214-220.

Teisl, M. F., Roe, B., \& Hicks, R. L. (2002). Can eco-labels tune a market? Evidence from dolphin-safe labeling. Journal of Environmental Economics and Management, 43(3), 339-359. 
Teisl, M. F., Rubin, J., \& Noblet, C. L. (2008). Non-dirty dancing? Interactions between eco-labels and consumers. Journal of Economic Psychology, 29(2), 140-159.

Tingley, C., Bigelow, D., Allen, R., \& Jochson, J. (2011). An investigation into reusable cutlery solutions. University of British Columbia, Course APSC-261: Technology and Society. Retrieved from https://open.library.ubc.ca/clRcle/collections/undergraduateresearch/18861/ items/1.0108437

TNO (2007): Single use Cups or Reusable (coffee) Drinking Systems: An Environmental Comparison; prepared for Benelux Disposables Foundation by TNO; Apeldoorn, The Netherlands.

To, K., \& Chan, W. (2006). A life-cycle and economic analysis: paper versus ceramic plates in the Barn Restaurant. Retrieved from https://open.library.ubc.ca/clRcle/collections/ undergraduateresearch/18861/items/1.0108084

Unkelsbay, N. F., Maxcy, R. B., Knickrehm, M. E., Stevenson, K. E., Cremer, M. L., \& Matthews, M. E. (1977). Foodservice-systems: Product flow and microbial quality and safety of foods. Univ. of Missouri, College of Agric. Agr. Exp. Stat. Research Bull, 1018.

Van Dam, Y. K. (1996). Environmental assessment of packaging: The consumer point of view. Environmental management, 20(5), 607-614.

Van der Harst, E., \& Potting, J. (2013). A critical comparison of ten disposable cup LCAs. Environmental impact assessment review, 43, 86-96.

Van der Harst-Wintraecken, E. J. (2015). Robustness of life cycle assessment results: influence of data variation and modelling choices on results for beverage packaging materials. Wageningen University.

Vercalsteren, A., Spirinckx, C., \& Sarlée, W. (2006). 4 types of drinking cups used on events: Life Cycle Assessment and Eco-Efficiency Analysis. In 13th CIRP INTERNATIONAL CONFERENCE ON LIFE CYCLE ENGINEERING.

Vercalsteren, A., Spirinckx, C., Geerkens, T., \& Claeys, P. (2006). Comparative LCA of 4 types of drinking cups at events. OVAM, Public Waste Agency for the Flemish Region, 390.

Vigon, B. W., Vigon, B. W., \& Harrison, C. L. (1993). Life-cycle assessment: Inventory guidelines and principles.

Vogtländer, J. G. (2010). A Practical Guide to LCA for Students, Designers and Business Managers: Cradle-to-grave and Cradle-to-cradle. VSSD. 
von Falkenstein, E., Wellenreuther, F., \& Detzel, A. (2010). LCA studies comparing beverage cartons and alternative packaging: can overall conclusions be drawn? The International Journal of Life Cycle Assessment, 15(9), 938-945.

Wachter, B., Creighton, A., Schmitz, M., \& Thayer, F. (2013). A Life Cycle Analysis and Cost Comparison of Dining Ware in the Alfred Packer Grill. Fine Dining Zero Waste: Evaluation and Recommendations for Achieving CUSG Zero Waste Goals at the Alfred Packer Restaurant and Grill. Retrieved from http://www.colorado.edu/envs/sites/default/files/ attached-files/Chapter_4_Life_Cycle_Analysis_and_Cost_Comparison.pdf

Wakelin, D., Doyle, S., Andrews, C., Mountford, S., \& Daeid, N. N. (2008). Network developing forensic applications of stable Isotope Ratio Mass Spectrometry conference 2005. Science \& Justice, 48(2), 79-90, p. 26.

Weber, C. L., Jaramillo, P., Marriott, J., \& Samaras, C. (2010). Life cycle assessment and grid electricity: what do we know and what can we know?

Weidema, B. (2014). Has ISO 14040/44 failed its role as a standard for life cycle assessment? Journal of Industrial Ecology, 18(3), 324-326.

Weidema, B. P., \& Schmidt, J. H. (2010). Avoiding allocation in life cycle assessment revisited. Journal of Industrial Ecology, 14(2), 192-195.

Weidema, B. P., \& Wesnaes, M. S. (1996). Data quality management for life cycle inventories-an example of using data quality indicators. Journal of cleaner production, 4(3-4), 167-174.

Weidema, B., Wenzel, H., Petersen, C., \& Hansen, K. (2004). The product, functional unit and reference flows in LCA. Environmental News, 70, 1-46.

Weiss, M., Haufe, J., Carus, M., Brandão, M., Bringezu, S., Hermann, B., \& Patel, M. K. (2012). A review of the environmental impacts of biobased materials. Journal of Industrial Ecology, 16(s1), S169-S181.

Weitz, K., Sharma, A., Vigon, B., Price, E., Norris, G., Eagan, P., ... \& Veroutis, A. (1999). Streamlined life-cycle assessment: a final report from the SETAC North America streamlined LCA workgroup. Society of Environmental Toxicology and Chemistry (SETAC) and SETAC Foundation for Environmental Education.

Wenzel, H., Villanueva, A., \& Wenzel, H. (2006). The significance of boundary conditions and assumptions in the environmental life cycle assessment of paper and cardboard waste management strategies. An Analytical Review of Existing Studies. 
Wolksa, J. (2005). Safeguarding the environment-XRF analysis of heavy metals in polyethylene. Plastics, Additives and Compounding, 7(1), 36-39.

Woods, L., \& Bakshi, B. R. (2014). Reusable vs. disposable cups revisited: guidance in life cycle comparisons addressing scenario, model, and parameter uncertainties for the US consumer. The International Journal of Life Cycle Assessment, 19(4), 931-940.

Zackrisson, M., Rocha, C., Christiansen, K., \& Jarnehammar, A. (2008). Stepwise environmental product declarations: ten SME case studies. Journal of Cleaner Production, 16(17), 1872-1886.

Zamagni, A., Buttol, P., Porta, P. L., Buonamici, R., Masoni, P., Guinée, J., ... \& Pretato, U. (2008). Critical review of the current research needs and limitations related to ISO-LCA practice. Deliverable D7 of work package, 5, 106.

Zarrilli, S., Jha, V., \& Vossenaar, R. (1997). Eco-labelling and international trade.

Ziada 2009 study (Ziada, H. (2009). Disposable coffee cup waste reduction study. Unpublished manuscript, McMaster University, Hamilton, Ontario. Retrieved from http://msep.mcmaster. ca/epp/publications/DisposableCoffeeCup.pdf.

Ziada, H. (2009). Disposable coffee cup waste reduction study. Unpublished manuscript, McMaster University, Hamilton, Ontario. Retrieved from http://wbooth.mcmaster.ca/epp/publications/ student/DisposableCoffeeCup. pdf.

Zieba-Palus, J., Borusiewicz, R., \& Kunicki, M. (2008). PRAXIS-combined $\mu$-Raman and $\mu$-XRF spectrometer.

\section{Non-scientific References}

To support the study of the Food Service and FSD sectors much of the information is derived from non-academic sources. The following sources, in alphabetic order, are referenced in the text.

http://www.bunzl.com/ /media/Files/B/Bunzl-PLC/reports-and-presentations/ar-2014.pdf, p. 34, accessed 21/01/2016

Interview Accum and Anbao, 2017.

2010 study by the National Restaurant Association (www.restaurant.org/research), accessed $27 / 10 / 2015$

2011 Marketline report ((www.marketline.com), accessed 12/11/2015 
A Live Science study in 2012 (http://www.livescience.com/16297-coffee-facts-national-coffee-dayinfographic.html), accessed 01/12/2015

A PIRA-Smithers report - The Future of Foodservice Packaging and Disposables to 2016 - (www. smitherspira.com/products/market-reports/packaging/end-use-markets/foodservicepackaging-disposables-to-2016), accessed 27/10/2015

A PIRA-Smithers study in 2013 (http://www.foodnavigator-asia.com/Markets/China-s-foodservicepackaging-market-to-overtake-US), accessed 27/10/2015

Allegra Strategies in 2012 (www.allegrastrategies.com), accessed 01/12/2015

ASTM D-1238: ISO 1133 - http://www.astm.org/Standards/D1238

Businessvibes (Endersen, L., O’Mahony, J., Hill, C., Ross, R. P., McAuliffe, O., \& Coffey, A. (2014). Phage therapy in the food industry. Annual review of food science and technology, 5, 327-349.),

CarbonClear. (2012). Disposable Cups vs. Reusable Cups: Solving the Carbon Intensity Question. Retrieved from http://carbonclear.com/files/Reuseable_vs_Disposable_Cups_2012.pdf

CML2001 100a, Ecoinvent v3.1, high voltage production mix - (http://www.ecoinvent.org/)

Corbion Purac - Processing Guide Rev.No. 1 https://www.corbion.com/media/494327/pcg-sheetand-film-extrusion.pdf - downloaded 20/08/2018

CPA/NACE codes (Classification of Products by Activity/Nomenclature statistique des activités économiques dans la Communauté Européenne).

CSCI Pacli 2017 - HIPS lid production in the CSCI manufacturing plant in Nanjing - measured by the author.

Deloitte in 2012 (http://www2.deloitte.com/content/dam/Deloitte/pt/Documents/manufacturing/ pt(en)_dc_foodbeverage2012_15102009.pdf), accessed 01/12/2015

Denkstatt 2018 - Life Cycle Inventories of Single Use Plastic Products and their Alternatives - Part of "Study to explore links between production, the environment and environmental policy"

DFE2009 Disposable Coffee Cups cited 10/102015 https://en.wikiversity.org/wiki/Design_for_the_ Environment/Disposable_Coffee_Cups

DIN 19303 - Paperboard - Terms and grades STANDARD by Deutsches Institut Fur Normung E.V. (German National Standard), 09/01/2005 
Ecoinvent v3 (http://www.ecoinvent.org/).

Ecoinvent v3.1 2015 - (http://www.ecoinvent.org/)

Ecoinvent v3.4 2017 - (http://www.ecoinvent.org/)

EN 15804

EPD General Program Instructions 2015

EU Directive 92/75/EC energy consumption-labelling scheme (http://eur-lex.europa.eu/legalcontent/en/ALL/?uri=CELEX:31992L0075)

EU Directive 92/75/EC energy-labelling scheme

EU PEF "Mid-Term Conference on the Environmental Footprint Pilot Phase" (Brussels November 2015)

EU Product Environmental Footprint (PEF), specifically the PEF category rules (PEFCR). (http:// ec.europa.eu/environment/eussd/pdf/footprint/PEF\%20methodology\%20final\%20draft.pdf)

EU, COM (2018) 340/2 2018/0172 (COD) Proposal for a DIRECTIVE OF THE EUROPEAN PARLIAMENT AND OF THE COUNCIL on the reduction of the impact of certain plastic products on the environment

EU. Final Report Summary - HECTOR (Eating Out: Habits, Determinants and Recommendations for Consumers and the European Catering Sector) https://cordis.europa.eu/result/rcn/47517 en.html

Executive Summary of the Product Environmental Footprint (PEF) Guide dated 04/05/2013

Food Service Market in the Netherlands (http://fsin.nl/nieuws/25/poster-foodservicemarkt-2010verschenen), accessed 27/10/2015

food service. (n.d.). Dictionary.com Unabridged. Retrieved June 20, 2017 from Dictionary.com website http://www.dictionary.com/browse/food-service

Franklin Associates. (2011b). Life cycle inventory of foam polystyrene, paper-based, and PLA foodservice products (Prepared for the Plastic Foodservice Packaging Group) (p. 236 pages). Retrieved from https://plasticfoodservicefacts.com/Life-Cycle-Inventory-FoodserviceProducts 
Franklin study into FSD (http://iso-pack.com/wp-content/uploads/2014/10/Peer_Reviewed_ Foodservice_LCA_Study-2011.pdf cited 10/10/2015)

FSIN (2010). Foodservice Monitor Jaarreport 2010, Food service Institute Nederland, accessed 27/10/2015

Grant, T. 2009: Lecture http ://www.youtube.com/watch ?v=InOCOS191mA : 2.20 minutes Hoofdproductschap Detailhandel (Staatscourant 2013).

http://assets.storaenso.com/se/renewablepackaging/DownloadDocuments/CupformaNatura2PE-12-15-en.pdf

http://assets.storaenso.com/se/renewablepackaging/DownloadDocuments/CupformaNatura-PE15-en.pdf cited 01/08/2017

http://ec.europa.eu/environment/eussd/pdf/footprint/PEF\%20methodology\%20final\%20draft.pdf http://ec.europa.eu/environment/eussd/smgp/conference_2015_en.htm 9.07min, 28/11/2015

http://ec.europa.eu/environment/gpp/index_en.htm 17/12/2017

http://ecophys.utah.edu/uploads/3/1/8/3/31835701/447.pdf p. 268 cited 10/01/2016

http://eur-lex.europa.eu/legal-content/EN/TXT/PDF/?uri=CELEX:32010R1061\&from=EN -, accessed 24/09/2016

http://eur-lex.europa.eu/legal-content/EN/TXT/PDF/?uri=OJ:L:2013:124:FULL\&from=EN 01/12/2015

http://eur-lex.europa.eu/LexUriServ/LexUriServ.do?uri=OJ:L:2005:149:0022:0039:EN:PDF DIRECTIVE 2005/29/EC Art.12 01/11/2015

http://foodservicepackaging.org.uk/members/, accessed 06/03/2016

http://fsin.nl/, accessed 27/10/2015

http://iso-pack.com/wp-content/uploads/2014/10/Peer_Reviewed_Foodservice_LCA_Study-2011. pdf cited 10/10/2015

http://proudlymadeineurope.com/news/eu-legislation-on-country-of-origin/ 01/11/2015

http://www.alibaba.com/products/F0/disposable_cutlery, accessed 06/03/2016 
http://www.bbc.com/news/business-41251451, accessed 14/09/2017

http://www.britannica.com/topic/Smoot-Hawley-Tariff-Act cited 28/10/2015.

http://www.cbs.nl/NR/rdonlyres/C5C32923-36E4-412C-A30B-AF743D1E7809/0/

ToelichtingverschilleninmetingenhorecaCBSFoodstep.pdf, accessed 27/10/2015

http://www.ccilc.pt/sites/default/files/eu_sme_centre_report_-_the_food_and_beverage_market_in_ china_update_-_july_2015.pdf, accessed 27/10/2015

http://www.codescentre.com/media/1013/665-framework-environmental-claims_july-2011.pdf

http://www.environdec.com/Documents/GPI/General\%20Programme\%20Instructions\%20v2.5.pdf

http://www.environdec.com/Documents/GPI/General-Programme-Instructions-v2.5.pdf, accessed 01/12/2015

http://www.environdec.com/en/PCR/PCR-Search/?\&query=food\%20service, accessed $01 / 12 / 2015$

http://www.fda.gov/downloads/Food/GuidanceRegulation/RetailFoodProtection/FoodCode/ UCM374510.pdf, accessed 01/12/2015

http://www.fpi.org/fpi/files/ccLibraryFiles/Filename/000000000192/20080211153727_2.pdf, accessed $12 / 11 / 2015$

http://www.fpi.org/Our-Members, accessed 06/03/2016

http://www.freedoniagroup.com/industry-study/2831/world-foodservice-disposables.htm, accessed 21/10/2015

http://www.gabi-software.com/fileadmin/GaBi_Manual/GaBi_6_manual.pdf, accessed 10/06/2017

http://www.globalsources.com/manufacturers/Plastic-Knife-Fork-And-Spoon.html, accessed 06/03/2016

http://www.grrn.org/assets/pdfs/wasting/WRUS.pdf p. 16, accessed 01/12/2015

http://www.lca2go.eu/tool.en.html, accessed 10/06/2017

http://www.no-burn.org/community-action-propels-the-taiwanese-government-towards-zerowaste, accessed 01/12/2015 
http://www.openlca.org, accessed 10/06/2017

http://www.pack4ecodesign.org/index_en.html, accessed 10/06/2017

http://www.smithsonianmag.com/arts-culture/the-unnatural-history-of-the-dixie-cup-119828457/ ?no-ist, accessed 01/12/2015

http://www.solidworks.com/sw/products/simulation/sustainability-xpress.htm, accessed 24/06/2017

https://en.wikipedia.org/wiki/Foodservice, accessed 01/12/2015

https://www.ahdictionary.com/word/search.html?q=food+service, accessed 01/12/2015

https://www.fastcompany.com/1693703/starbucks-cup-dilemma, accessed 01/12/2015

https://www.grantadesign.com/products/ces/eco.htm, accessed 24/06/2017

https://www.ineos.com/globalassets/ineos-group/businesses/ineos-olefins-and-polymers-usa/ products/technical-information--patents/ineos_polypropylene_processing_guide.pdf

https://www.pack2go-europe.com/en/membership/aug/ 2016, accessed 06/12/2016

https://www.pre-sustainability.com/download/SimaPro8Tutorial.pdf, accessed 10/06/2017

https://www.rocket-internet.com/themes/rocket3/download/Feb\%202015\%20Business\%20

Update.pdf, accessed 20/6/2017

In 2010, Starbucks reported (http://www.fastcompany.com/1693703/starbucks-cup-dilemma), accessed 01/12/2015

In 2011, the UK Daily Telegraph newspaper (http://www.telegraph.co.uk/finance/newsbysector/ retailandconsumer/8357456/Britains-coffee-love-affair-by-numbers.html), accessed $01 / 12 / 2015$

Insight, I. G. (2012). Franchise business economic outlook for 2013. Online im Internet unter: http://emarket. franchise. org/2012FranchiseBusinessOutlook. pdf (01/05/2012), accessed 01/05/2012

ISO 14021:1999

ISO 14024:1999

ISO 14025:2006 
ISO 14040 series (http://www.iso.org/iso/iso_catalogue/catalogue_tc/catalogue_tc_browse. htm?commid=54854)

ISO, E. (2006). 14025: 2010. Environmental labels and declarations-Type III environmental declarations-Principles and procedures (ISO 14025: 2006) p. 10 Art.6.7.2 a)

ISO, E. (2006). 14025: 2010. Environmental labels and declarations-Type III environmental declarations-Principles and procedures (ISO 14025: 2006)

Mid-Term Conference on the Environmental Footprint Pilot Phase - Brussels $3 \& 4$ November 2015 - http://ec.europa.eu/environment/eussd/smgp/conference_2015_en.htm 9.07min, accessed 28/11/2015

Multi-Stakeholder Dialogue on Environmental Claims 2013

NPD Group/Crest in 2010 (https://www.npd.com/wps/portal/npd/us/industry-expertise/ foodservice/), accessed 27/10/2015

OECD, 1997, Eco-Labelling, Actual Effects of Selected Programme, Paris

PE Americas 2009 - Comparative Life Cycle Assessment Ingeo ${ }^{\text {TM }}$ biopolymer, PET, and PPDrinking Cups

PEF Guide, 2012 p. 15

Plastic ZERO - Public Private Cooperations for Avoiding Plastic as a Waste- LCA study into "Comparing disposal versus reuse of food packaging" for various cities public procurement, such as Copenhagen and Malmo, thermoforming was chosen in the LCA as the method to make plastic cutlery (http://www.plastic-zero.com/media/58705/Ica_eat_project_report_ july_2014__action_4.2.pdf cited 18/02/2016).

Pro-Intel 2010 Study http://www.bordbia.ie/industry/events/SpeakerPresentations/2010/ MeatMarketProspectsSeminarJan2010/TRENDS\%20IN\%20EUROPEAN\%20 FOODSERVICE\%20AND\%20CONSEQUENCES\%2OFOR\%20THE\%20MEAT\%20 SECTOR\%20-\%2OH\%2ODoring,\%2OPro\%2OIntal.pdf, accessed 12/11/2015

prweb.com http://www.prweb.com/releases/foodservice_industry/restaurants_hotels/ prweb2524434.htm of the 23/06/2009, accessed 12/11/2015

Regulation (EU) No 1169/2011 on the provision of food information to consumers obliges to take up the $\mathrm{CoO}$ for some products like origin labelling for meat from pig, sheep, goat and poultry

The International Environmental Product Declaration (EPD). http://www.environdec.com/ 
US Centers for Disease Control and Prevention report 213 of September 2015

(www.cdc.gov/nchs/data/databriefs/db213.htm 27-10-2015), accessed 27/10/2015

USDA, Economic Research Service analysis using data from the 1977-78 Nationwide Food Consumption Survey and the 2005-08 National Health and Nutrition Examination Survey, accessed 27/10/2015

VROM 1991, Reusable or Disposable

White Lined Chipboard (chipboard production, white lined, RER, Author: Emilia Moreno Ruiz active, Ecoinvent v3.1 2015) (http://www.ecoinvent.org/)

www.foodservicealliance.be, accessed 27/10/2015

www.foodstep.com, accessed 27/10/2015 


\section{Appendices}

1. Appendix A - Hoofdproductschap Detailhandel (Staatscourant 2013) document. Page 342.

2. Appendix B - Questionnaire to five purchasers of major FSD traders in the Netherlands, regarding likely stakeholder involvement in developing a comparative ECS and various points regarding the FSD market and trading activities. Page 344.

3. Appendix C - Questionnaire sent to 18 LCA experts regarding the current methods of collection of product economic inventory data. Page 346.

4. Appendix D - Details and interpretation of a discussion held at the IAPRI (International Association of Packaging Research Institutes) Symposium in May 2017, involving four packaging LCA specialists. Page 348.

5. Appendix E - Explanation of the midpoint categories in ReCiPe and their associated equivalent units. Page 349.

6. Appendix $\mathbf{F}$ - List of ReCiPe endpoints Total total figures for each product in the $22 \mathrm{~cm}$ plate range. Page 350.

7. Appendix $\mathbf{G}$ - List of the density of common polymers with filler levels from $1 \%$ to 55\%. Page 351.

8. Appendix H - Results of expert interview, regarding the origin of garbage bags, with three garbage bag purchasers. Page 353.

9. Appendix I-Results of an interview, regarding the paper source and cup conversion origin of disposable hot beverage paper cups, with five FSD cup purchasers. Page 354.

10. Appendix J - Calculations related to percentage waste figures in paper plate manufacturing. Page 355.

11. Appendix K - Details related to this range of glasses studied in Chapter 11. Page 356.

12. Appendix $\mathbf{L}$ - Discussion with carton product purchasing experts regarding carton board source. Page 358.

13. Appendix $\mathbf{M}$ - Names, in alphabetical order, of the five experts who participated in the expert interviews in Chapter 12. Page 359.

14. Appendix $\mathbf{N}$ - Questionnaire sent to each of the experts interviewed in Chapter 12 or used when conducting a face-to-face interview. Page 360. 
Appendix A - p. 59 - Hoofdproductschap Detailhandel (Staatscourant 2013) document.

Staatscourant: Besluit van de Minister van Volksgezondheid, Welzijn en Sport van 4 november 2013, 139845-108181-VGP houdende intrekking van de goedkeuring van de Hygiënecode Ambulante Handel Verkoop Eet- en Drinkwaren, juni 2004, versie 1 (Government Gazette: Decree of the Minister of Health, Welfare and Sport of 4 November 2013, 139845-108181-VGP revoking the approval of the Hygiene Code Ambulatory Trade in Food and Beverage Sales, June 2004, version 1)

\begin{tabular}{|c|c|c|c|c|c|}
\hline 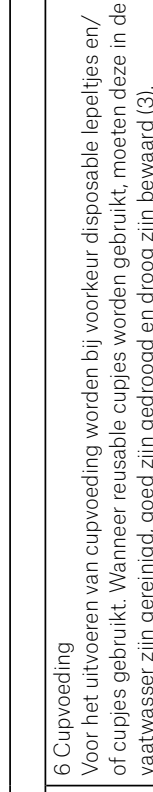 & 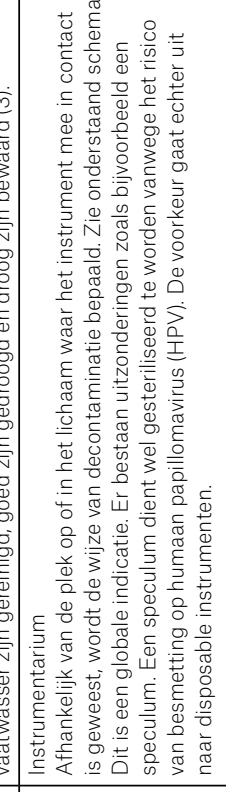 & 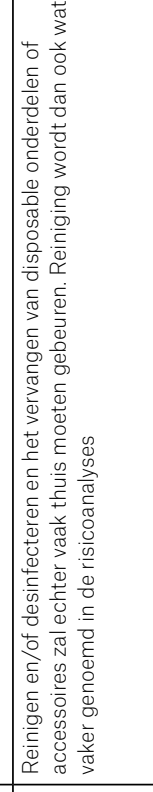 & 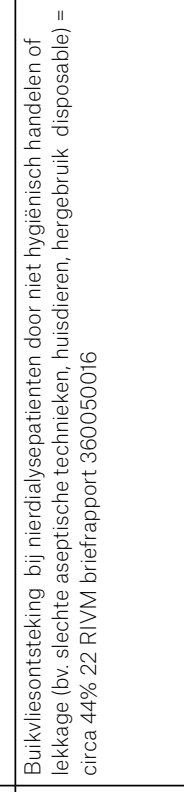 & 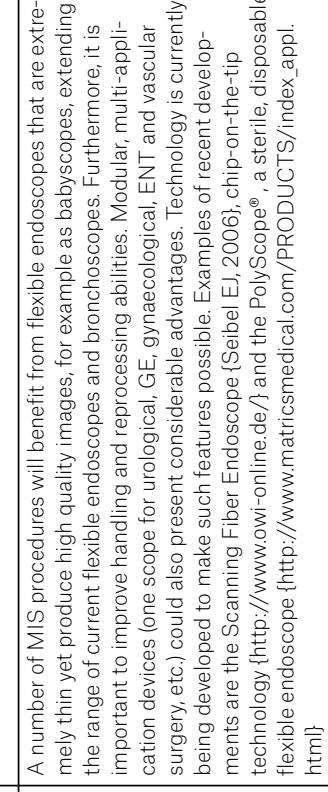 & 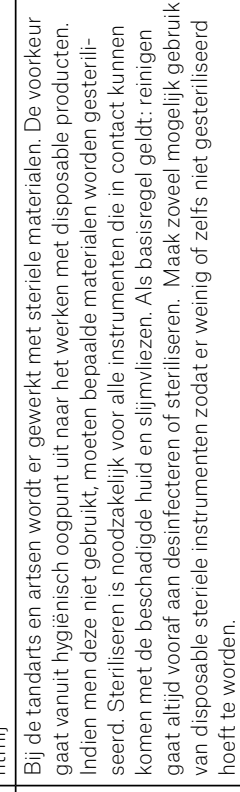 \\
\hline 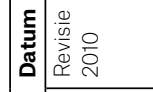 & 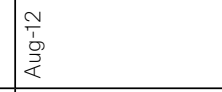 & 冬 & $\mid \begin{array}{l}\infty \\
\overbrace{}^{2} \\
\end{array}$ & 令 & 离 \\
\hline 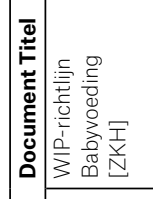 & 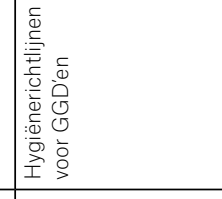 & 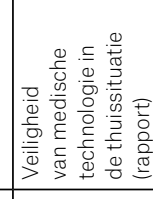 & 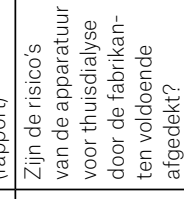 & 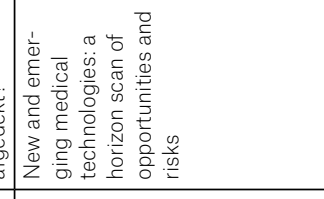 & 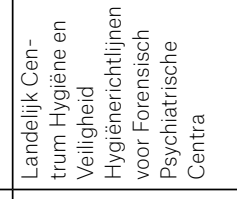 \\
\hline 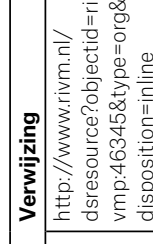 & 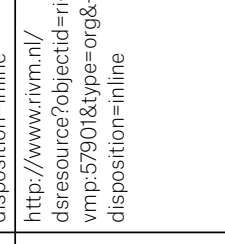 & 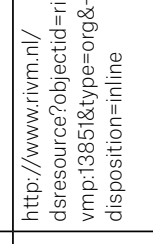 & 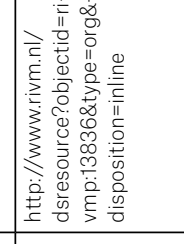 & 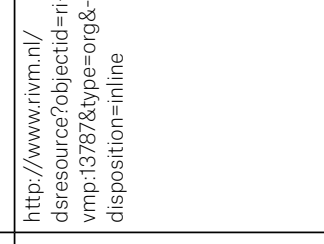 & 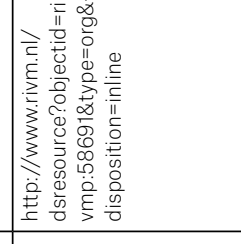 \\
\hline 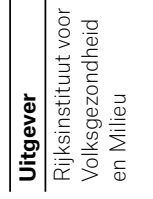 & 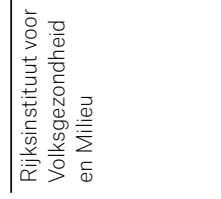 & 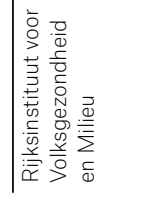 & 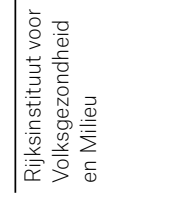 & 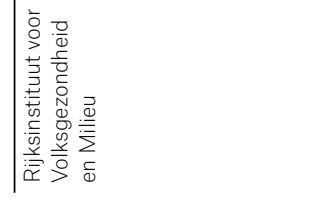 & 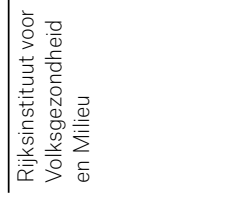 \\
\hline
\end{tabular}




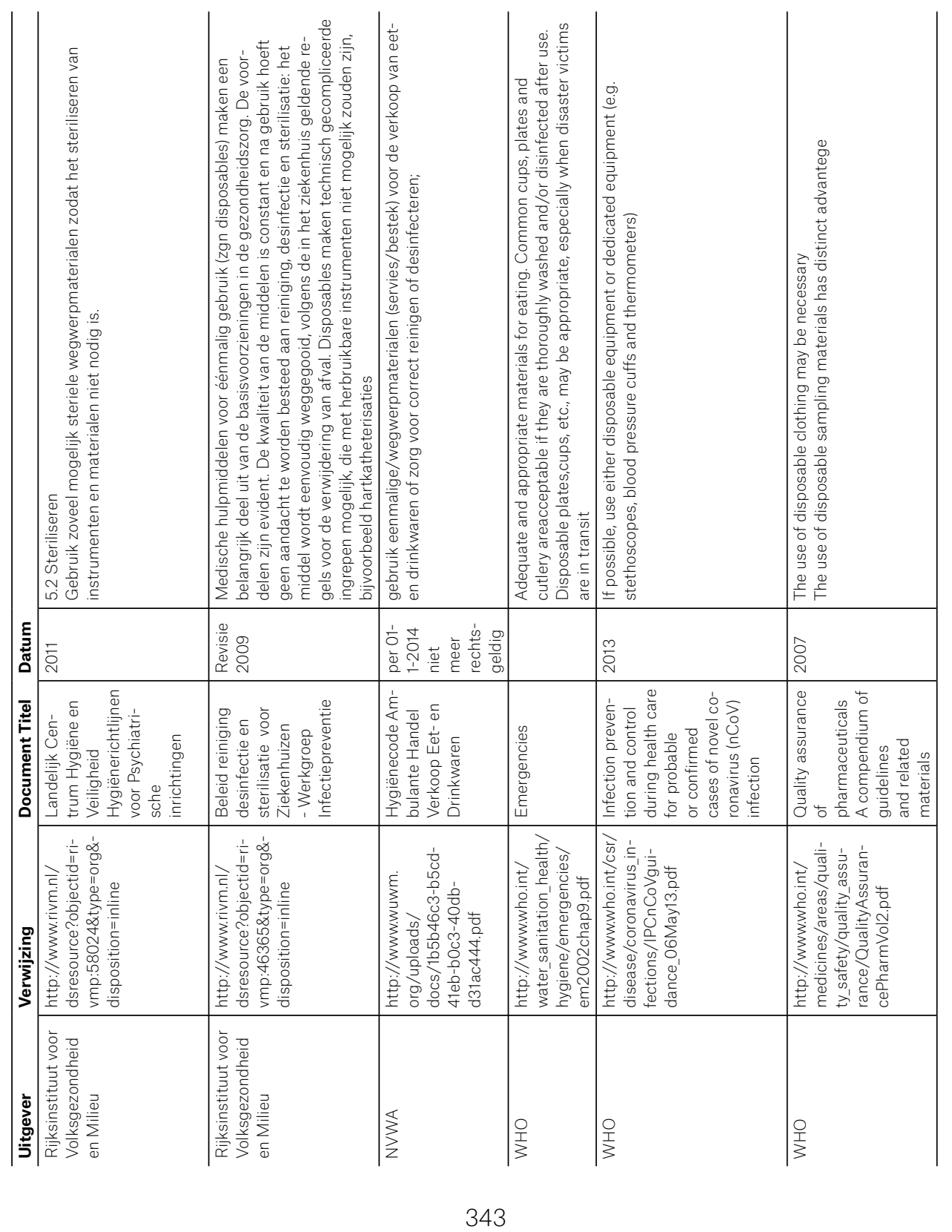


Appendix B - pp. 57, 69, 76 - Questionnaire to five purchasers of major FSD traders in the Netherlands, regarding likely stakeholder involvement in developing a comparative ECS and various points regarding the FSD market and trading activities.

- Jaap Vreugdenhil - Paardekooper Verpakkingen

- Bianca Koning - Depa Disposables

- Rob Verhoeven - TVD Verpakkingen

- $\quad$ Rene Klaassen - Halma Packaging

- Joop Bouwhuis - Van Der Windt Verpakkingen

\section{Questionnaire regarding Food Service Disposables}

1. Do you consider the food service disposable (FSD) market to have been very competitive, over the last 10 years?

$\square$ Yes

2. Do you feel that competitors would be prepared to be cooperative with you if you want to make a study of the relative environmental benefit of your product over theirs, knowing that to do so they would have to divulge the country of origin of their product and its material composition?

$\square$ Yes

$\square$ No

3. If you were to be presented with samples of each of your most knowledgeable FSD product categories (i.e. cold cups, cutlery, paper cups) from your domestic market, for what percentage of these items do you feel you could identify the source manufacturer or country of origin?
$\square 25 \%$
$\square 50 \%$
$\square 75 \%$
$\square$ All

4. What is the minimum order value of the average small FSD wholesalers that sells to end-user food service outlets such as chip shops and snack bars?

5. What do you estimate their percentage margin to be when these wholesalers sell to the smaller end-user food service outlets? 


\begin{tabular}{c|c|c|c|c|c}
\hline \multicolumn{7}{c}{ Questionnaire regarding Food Service Disposables } \\
\hline Company & Paardekooper & Depa & TVD & Halma & Van der Windt \\
\hline Interviewee & Jaap Vreugdenhil & Bianca Koning & Rob Verhoeven & Rene Klaassen & Joop Bouwhuis \\
\hline Function & $\begin{array}{c}\text { Strategic } \\
\text { Purchaser }\end{array}$ & Purchaser & $\begin{array}{c}\text { Purchasing } \\
\text { Manager }\end{array}$ & $\begin{array}{c}\text { Purchasing } \\
\text { Manager }\end{array}$ & $\begin{array}{c}\text { Purchasing } \\
\text { Manager }\end{array}$ \\
\hline $\begin{array}{c}\text { Question } \\
\text { No.1 }\end{array}$ & Yes & Yes & Yes & Yes & Yes \\
\hline $\begin{array}{c}\text { Question } \\
\text { No.2 }\end{array}$ & No & No & No & $\begin{array}{c}\text { No (but with } \\
\text { reservations) }\end{array}$ & No \\
\hline $\begin{array}{c}\text { Question } \\
\text { No.3 }\end{array}$ & $50 \%$ & $75 \%$ & $50 \%$ & NC & $50 \%$ \\
\hline $\begin{array}{c}\text { Question } \\
\text { No.4 }\end{array}$ & $€ 350$ & $€ 200$ & $€ 250$ & NC & $€ 250$ \\
\hline $\begin{array}{c}\text { Question } \\
\text { No.5 }\end{array}$ & $30 \%$ & $40 \%$ & $35 \%$ & NC & $35 \%$ \\
\hline
\end{tabular}


Appendix C - p. 107 - Questionnaire sent to 18 LCA experts regarding the current methods of collection of product economic inventory data.

Dear XXXXXX,

I was hoping that you may be able to take a few minutes to help me with a research topic, given your position as a renowned expert in the field of Life Cycle Assessment.

I seek to understand the most common approaches taken to collecting product economic inventory data, in the absence of any stakeholder input, when performing a product LCA. I would be much obliged if you could kindly answer my following questions:

1. How often do you get a request to make an LCA based product study for which stakeholder input, associated with the product, is missing (can you estimate a percentage)?

2. If you do not have a material specification, how do you determine the input for the LCA? Can you describe this?

3. Is the budget that you have, to execute the LCA, of importance for this?

4. What would you consider to be the most important inventory data to collect?

5. Do you execute a sensitivity analysis (how often, percentage)?

6. How accurate do you feel your eventual result would be in absence of the product stakeholder input?

7. At a later stage I would like to discuss the findings of my research in a wider setting, with several LCA experts together. Are you willing to corporate in such a discussion?

I hope you are able to help.

Thank you in advance,

Kind Regards

Alan Campbell 
The following experts confirmed receipt of the questionnaire, although not all provided commentary:

- Prof. Jeroen Guinée PhD - Institute of Environmental Sciences (CML), Leiden University

- Andreas Ciroth PhD - Green Delta

- $\quad$ Prof. Mark Huijbregts PhD - Radboud University Nijmegen

- Jasper Scholten - Blonk Consultants - Manager Life Cycle Assessment

- Prof. José Potting, PhD - PBL Netherlands Environmental Assessment Agency

- $\quad$ Leigh Holloway, PhD - ECO3 Design Ltd - Senior Consultant

- $\quad$ dr.Ulphard Thoden van Velzen - Wageningen University

- Marten Toxopeus, M.E. - University of Twente

- An De Schryver - Environmental Footprint Team - EU DG ENVIRONMENT

- Melissa Huff - Senior Chemical Engineer \& Project Manager - Franklin Associates 
Appendix D - p. 108 - Details and interpretation of a discussion held at the IAPRI (International Association of Packaging Research Institutes) Symposium in May 2017, involving four packaging LCA specialists.

“Notification of a discussion with experts on (the input in) LCAs

People that have used LC's or executed LCA studies, or were involved in LCA studies

Date: 11 May 2017

Location: Lausanne

Occasion: IAPRI 28th Symposium

Present in parts of the discussion or in total:

- $\quad$ Rene Wever, prof.dr.ir. on Linköping University Sweden

- Søren Rahbek Østergaard, Danish Institute of Technology, head of packaging department

- Helén Williams, University of Karlstadt

- Marit Kvalvag Pettersen Nofima, Norway

I took a paper serviette from the table and asked how they would execute an LCA, not knowing where it came from. What follows hereafter is a summary of the discussion in my words.

If no data is available look into known studies, think about input like additives that are used, as far as known, data known from companies in the area, try to see where it comes from. Then mostly an average of known data is taken, knowing that this is not complete. If there is no known data, make presumptions.

An LCA should be seen as a scenario study, to get insight in the influence of the different steps. A sensitivity study should be executed. If there is no detailed input data, the outcome cannot be taken as detailed. This means that it can only be used to get insight in the influence of the different steps and not to compare items.

Roland ten Klooster

12 May $2017^{\prime \prime}$ 
Appendix E - p. 124 - An explanation of the midpoint categories in ReCiPe and their associated equivalent units.

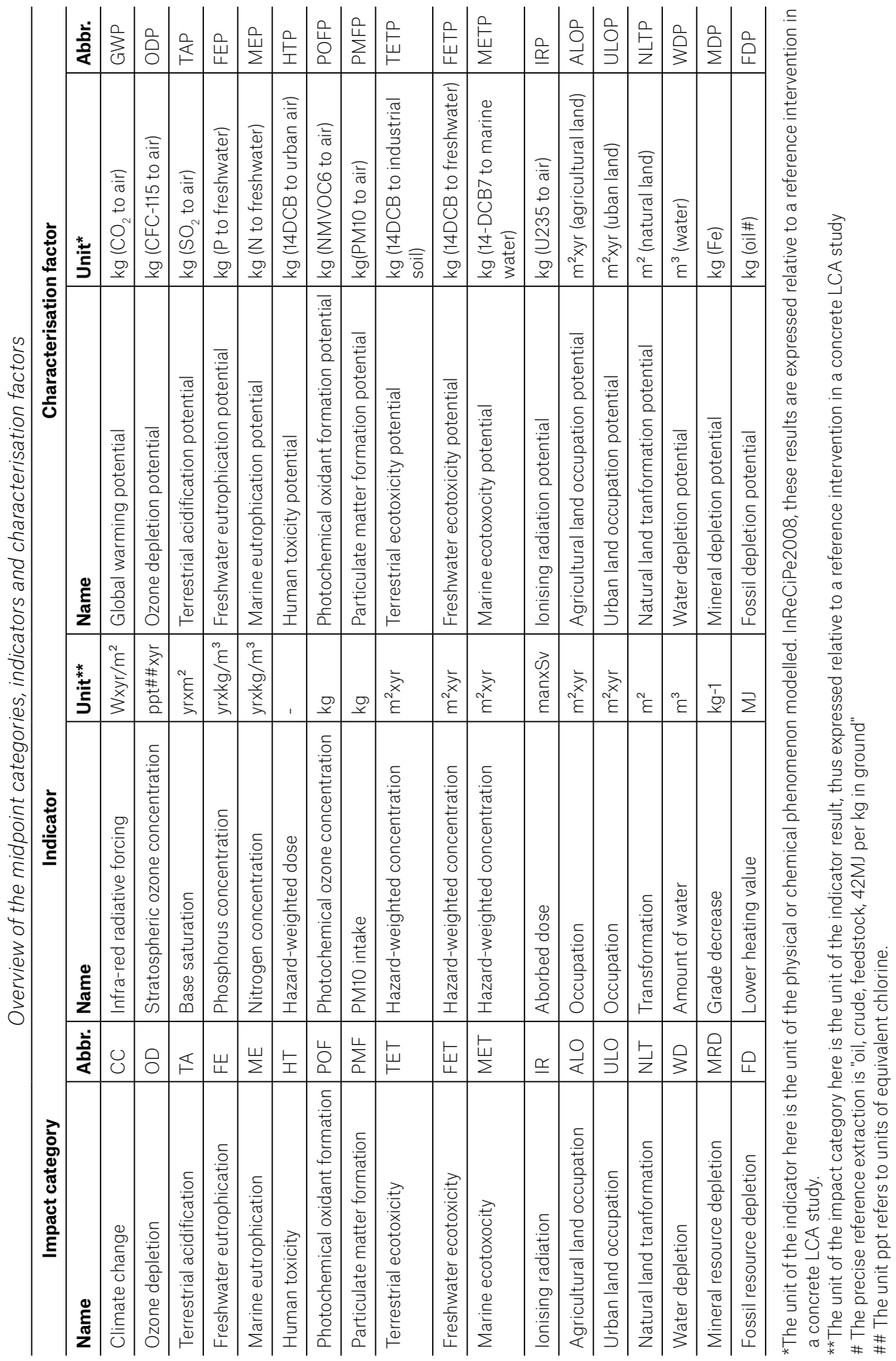


Appendix F - p. 157 - List of ReCiPe endpoints Total total figures for each product in the $22 \mathrm{~cm}$ plate range.

\begin{tabular}{|c|c|}
\hline PL22 Plates & ReCiPe Endpoints \\
\hline 1 & 0.00534 \\
\hline 2 & 0.00560 \\
\hline 3 & 0.00849 \\
\hline 4 & 0.00667 \\
\hline 5 & 0.00766 \\
\hline 6 & 0.00766 \\
\hline 7 & 0.01074 \\
\hline 8 & 0.01472 \\
\hline 9 & 0.00736 \\
\hline 10 & 0.00645 \\
\hline 11 & 0.00849 \\
\hline 12 & 0.01058 \\
\hline 13 & 0.00520 \\
\hline 14 & 0.00352 \\
\hline 15 & 0.0073 \\
\hline 16 & 0.00184 \\
\hline 17 & 0.00185 \\
\hline 18 & 0.00280 \\
\hline 19 & 0.00182 \\
\hline 20 & 0.00268 \\
\hline 21 & 0.00214 \\
\hline 22 & 0.00156 \\
\hline 23 & 0.00222 \\
\hline 24 & 0.00174 \\
\hline 25 & 0.00376 \\
\hline
\end{tabular}


Appendix G - p. 177 - List of the densities of common polymers with filler levels from $1 \%$ to $55 \%$.

\begin{tabular}{|c|c|c|c|c|c|c|c|}
\hline$\% \mathrm{CaCO}_{3}$ in $\mathrm{PS}$ & Density & $\begin{array}{c}\% \mathrm{CaCO}_{3} \\
\text { in PP }\end{array}$ & Density & $\begin{array}{c}\% \mathrm{CaCO}_{3} \text { in } \\
\text { HDPE }\end{array}$ & Density & $\begin{array}{c}\% \mathrm{CaCO}_{3} \text { in } \\
\text { LDPE }\end{array}$ & Density \\
\hline $0 \%$ & 1.05 & $0 \%$ & 0.905 & $0 \%$ & 0.95 & $0 \%$ & 0.92 \\
\hline $1 \%$ & 1.056 & $1 \%$ & 0.911 & $1 \%$ & 0.956 & $1 \%$ & 0.926 \\
\hline $2 \%$ & 1.063 & $2 \%$ & 0.917 & $2 \%$ & 0.963 & $2 \%$ & 0.932 \\
\hline $3 \%$ & 1.070 & $3 \%$ & 0.923 & $3 \%$ & 0.969 & $3 \%$ & 0.939 \\
\hline $4 \%$ & 1.076 & $4 \%$ & 0.930 & $4 \%$ & 0.975 & $4 \%$ & 0.945 \\
\hline $5 \%$ & 1.083 & $5 \%$ & 0.936 & $5 \%$ & 0.982 & $5 \%$ & 0.951 \\
\hline $6 \%$ & 1.090 & $6 \%$ & 0.943 & $6 \%$ & 0.989 & $6 \%$ & 0.958 \\
\hline $7 \%$ & 1.097 & $7 \%$ & 0.949 & $7 \%$ & 0.995 & $7 \%$ & 0.965 \\
\hline $8 \%$ & 1.104 & $8 \%$ & 0.956 & $8 \%$ & 1.002 & $8 \%$ & 0.971 \\
\hline $9 \%$ & 1.111 & $9 \%$ & 0.963 & $9 \%$ & 1.009 & $9 \%$ & 0.978 \\
\hline $10 \%$ & 1.118 & $10 \%$ & 0.970 & $10 \%$ & 1.016 & $10 \%$ & 0.985 \\
\hline $11 \%$ & 1.126 & $11 \%$ & 0.977 & $11 \%$ & 1.023 & $11 \%$ & 0.992 \\
\hline $12 \%$ & 1.133 & $12 \%$ & 0.984 & $12 \%$ & 1.030 & $12 \%$ & 0.999 \\
\hline $13 \%$ & 1.141 & $13 \%$ & 0.991 & $13 \%$ & 1.038 & $13 \%$ & 1.006 \\
\hline $14 \%$ & 1.148 & $14 \%$ & 0.998 & $14 \%$ & 1.045 & $14 \%$ & 1.014 \\
\hline $15 \%$ & 1.156 & $15 \%$ & 1.005 & $15 \%$ & 1.053 & $15 \%$ & 1.021 \\
\hline $16 \%$ & 1.164 & $16 \%$ & 1.013 & $16 \%$ & 1.060 & $16 \%$ & 1.029 \\
\hline $17 \%$ & 1.172 & $17 \%$ & 1.021 & $17 \%$ & 1.068 & $17 \%$ & 1.036 \\
\hline $18 \%$ & 1.180 & $18 \%$ & 1.028 & $18 \%$ & 1.076 & $18 \%$ & 1.044 \\
\hline $19 \%$ & 1.188 & $19 \%$ & 1.036 & $19 \%$ & 1.084 & $19 \%$ & 1.052 \\
\hline $20 \%$ & 1.196 & $20 \%$ & 1.044 & $20 \%$ & 1.092 & $20 \%$ & 1.060 \\
\hline $21 \%$ & 1.205 & $21 \%$ & 1.052 & $21 \%$ & 1.100 & $21 \%$ & 1.068 \\
\hline $22 \%$ & 1.213 & $22 \%$ & 1.060 & $22 \%$ & 1.108 & $22 \%$ & 1.076 \\
\hline $23 \%$ & 1.222 & $23 \%$ & 1.069 & $23 \%$ & 1.117 & $23 \%$ & 1.085 \\
\hline $24 \%$ & 1.230 & $24 \%$ & 1.077 & $24 \%$ & 1.125 & $24 \%$ & 1.093 \\
\hline $25 \%$ & 1.239 & $25 \%$ & 1.086 & $25 \%$ & 1.134 & $25 \%$ & 1.102 \\
\hline $26 \%$ & 1.248 & $26 \%$ & 1.095 & $26 \%$ & 1.143 & $26 \%$ & 1.111 \\
\hline $27 \%$ & 1.257 & $27 \%$ & 1.103 & $27 \%$ & 1.152 & $27 \%$ & 1.120 \\
\hline $28 \%$ & 1.267 & $28 \%$ & 1.112 & $28 \%$ & 1.161 & $28 \%$ & 1.129 \\
\hline
\end{tabular}




\begin{tabular}{|c|c|c|c|c|c|c|c|}
\hline$\% \mathrm{CaCO}_{3}$ in PS & Density & $\begin{array}{c}\% \mathrm{CaCO}_{3} \\
\text { in PP }\end{array}$ & Density & $\begin{array}{c}\% \mathrm{CaCO}_{3} \text { in } \\
\text { HDPE }\end{array}$ & Density & $\begin{array}{c}\% \mathrm{CaCO}_{3} \text { in } \\
\text { LDPE }\end{array}$ & Density \\
\hline $29 \%$ & 1.276 & $29 \%$ & 1.122 & $29 \%$ & 1.170 & $29 \%$ & 1.138 \\
\hline $30 \%$ & 1.286 & $30 \%$ & 1.131 & $30 \%$ & 1.180 & $30 \%$ & 1.147 \\
\hline $31 \%$ & 1.295 & $31 \%$ & 1.140 & $31 \%$ & 1.189 & $31 \%$ & 1.157 \\
\hline $32 \%$ & 1.305 & $32 \%$ & 1.150 & $32 \%$ & 1.199 & $32 \%$ & 1.167 \\
\hline $33 \%$ & 1.315 & $33 \%$ & 1.160 & $33 \%$ & 1.209 & $33 \%$ & 1.176 \\
\hline $34 \%$ & 1.325 & $34 \%$ & 1.170 & $34 \%$ & 1.219 & $34 \%$ & 1.186 \\
\hline \multirow[t]{21}{*}{$35 \%$} & 1.336 & $35 \%$ & 1.180 & $35 \%$ & 1.229 & $35 \%$ & 1.197 \\
\hline & & $36 \%$ & 1.190 & $36 \%$ & 1.240 & $36 \%$ & 1.207 \\
\hline & & $37 \%$ & 1.201 & $37 \%$ & 1.250 & $37 \%$ & 1.218 \\
\hline & & $38 \%$ & 1.212 & $38 \%$ & 1.261 & $38 \%$ & 1.228 \\
\hline & & $39 \%$ & 1.223 & $39 \%$ & 1.272 & $39 \%$ & 1.239 \\
\hline & & $40 \%$ & 1.234 & $40 \%$ & 1.283 & $40 \%$ & 1.250 \\
\hline & & $41 \%$ & 1.245 & $41 \%$ & 1.295 & $41 \%$ & 1.262 \\
\hline & & $42 \%$ & 1.256 & $42 \%$ & 1.306 & $42 \%$ & 1.273 \\
\hline & & $43 \%$ & 1.268 & $43 \%$ & 1.318 & $43 \%$ & 1.285 \\
\hline & & $44 \%$ & 1.280 & $44 \%$ & 1.330 & $44 \%$ & 1.297 \\
\hline & & $45 \%$ & 1.292 & $45 \%$ & 1.342 & $45 \%$ & 1.309 \\
\hline & & $46 \%$ & 1.305 & $46 \%$ & 1.355 & $46 \%$ & 1.322 \\
\hline & & $47 \%$ & 1.317 & $47 \%$ & 1.367 & $47 \%$ & 1.334 \\
\hline & & $48 \%$ & 1.330 & $48 \%$ & 1.380 & $48 \%$ & 1.347 \\
\hline & & $49 \%$ & 1.343 & $49 \%$ & 1.393 & $49 \%$ & 1.360 \\
\hline & & $50 \%$ & 1.357 & $50 \%$ & 1.407 & $50 \%$ & 1.374 \\
\hline & & $51 \%$ & 1.371 & $51 \%$ & 1.420 & $51 \%$ & 1.387 \\
\hline & & $52 \%$ & 1.385 & $52 \%$ & 1.434 & $52 \%$ & 1.401 \\
\hline & & $53 \%$ & 1.399 & $53 \%$ & 1.449 & $53 \%$ & 1.416 \\
\hline & & $54 \%$ & 1.413 & $54 \%$ & 1.463 & $54 \%$ & 1.430 \\
\hline & & $55 \%$ & 1.428 & $55 \%$ & 1.478 & $55 \%$ & 1.445 \\
\hline
\end{tabular}


Appendix H - p. 197 - Results of expert interview, regarding the origin of garbage bags, with three garbage bag purchasers. All bag $\mathrm{CoO}$ identified except those marked in yellow.

\begin{tabular}{|c|c|c|c|c|}
\hline Bag Roll Number & Description & Size & Thickness & Country of Origin \\
\hline 1 & Grey HDPE bags & $61 \times 80 \mathrm{~cm}$ & T20 - 11 my & Slovakia \\
\hline 2 & Grey HDPE bags & $61 \times 80 \mathrm{~cm}$ & T23 - 16 my & Slovakia \\
\hline 2.1 & Grey HDPE bags & $61 \times 80 \mathrm{~cm}$ & T23 - 16 my & Slovakia \\
\hline 3 & Blue HDPE Bags & $70 \times 110 \mathrm{~cm}$ & T20 - 12 my & Slovakia \\
\hline 4 & Blue HDPE Bags & $70 \times 110 \mathrm{~cm}$ & T25 - 14 my & Slovakia \\
\hline 5 & Blue HDPE Bags & $70 \times 110 \mathrm{~cm}$ & T30 - 20 my & Netherlands \\
\hline 6 & Blue HDPE Bags & $70 \times 110 \mathrm{~cm}$ & T30 - 18 my & Slovakia \\
\hline 7 & Grey HDPE bags & $60 \times 80 \mathrm{~cm}$ & $15 \mathrm{my}$ & Netherlands \\
\hline 8 & Grey HDPE bags & $60 \times 80 \mathrm{~cm}$ & $16 \mathrm{my}$ & Netherlands \\
\hline 9 & Blue HDPE Bags & $70 \times 110 \mathrm{~cm}$ & $16 \mathrm{my}$ & Netherlands \\
\hline 10 & Blue HDPE Bags & $70 \times 110 \mathrm{~cm}$ & $20 \mathrm{my}$ & Netherlands \\
\hline 11 & Blue HDPE Bags & $70 \times 110 \mathrm{~cm}$ & $25 \mathrm{my}$ & Vietnam \\
\hline 12 & Blue HDPE Bags & $70 \times 110 \mathrm{~cm}$ & $25 \mathrm{my}$ & Vietnam \\
\hline 13 & Grey HDPE bags & $61 \times 80 \mathrm{~cm}$ & $21 \mathrm{my}$ & Vietnam \\
\hline 14 & Blue HDPE Bags & $70 \times 110 \mathrm{~cm}$ & 29 my & $?$ \\
\hline 15 & Grey HDPE bags & $61 \times 80 \mathrm{~cm}$ & T23 & Europe? \\
\hline 16 & Blue HDPE Bags & $70 \times 110 \mathrm{~cm}$ & T30 & Europe? \\
\hline 17 & Grey HDPE bags & $61 \times 80 \mathrm{~cm}$ & T20 & Vietnam \\
\hline 18 & Blue HDPE Bags & $70 \times 110 \mathrm{~cm}$ & T30 & Vietnam \\
\hline 19 & Blue HDPE Bags & $70 \times 110 \mathrm{~cm}$ & $\mathrm{~T} 25$ & Vietnam \\
\hline 20 & Grey HDPE bags & $61 \times 80 \mathrm{~cm}$ & $\mathrm{~T} 23$ & Vietnam \\
\hline 21 & Blue HDPE Bags & $70 \times 110 \mathrm{~cm}$ & $\mathrm{~T} 20$ & Vietnam \\
\hline 22 & Grey HDPE bags & $60 \times 80 \mathrm{~cm}$ & $\mathrm{~T} 20$ & China \\
\hline 23 & Grey HDPE bags & $60 \times 80 \mathrm{~cm}$ & $\mathrm{~T} 23$ & China \\
\hline 24 & Blue HDPE Bags & $70 \times 110 \mathrm{~cm}$ & $\mathrm{~T} 20$ & China \\
\hline 25 & Blue HDPE Bags & $70 \times 110 \mathrm{~cm}$ & $\mathrm{~T} 25$ & China \\
\hline 26 & Grey HDPE bags & $61 \times 80 \mathrm{~cm}$ & $\mathrm{~T} 20$ & Europe? \\
\hline 27 & Grey HDPE bags & $60 \times 80 \mathrm{~cm}$ & $25 \mathrm{my}$ & Poland \\
\hline 28 & Blue HDPE Bags & $70 \times 110 \mathrm{~cm}$ & $18 \mathrm{my}$ & Poland \\
\hline 29 & Grey HDPE bags & $60 \times 80 \mathrm{~cm}$ & $14 \mathrm{my}$ & Asia \\
\hline 30 & Blue HDPE Bags & $70 \times 110 \mathrm{~cm}$ & $27 \mathrm{my}$ & Poland \\
\hline 31 & Blue HDPE Bags & $70 \times 110 \mathrm{~cm}$ & $21 \mathrm{my}$ & Poland \\
\hline 32 & Grey HDPE bags & $60 \times 80 \mathrm{~cm}$ & $16 \mathrm{my}$ & $?$ \\
\hline 33 & Blue HDPE Bags & $70 \times 110 \mathrm{~cm}$ & T25 & Europe \\
\hline 34 & Blue HDPE Bags & $70 \times 110 \mathrm{~cm}$ & $20 \mathrm{my}$ & Poland \\
\hline 35 & Blue HDPE Bags & $70 \times 110 \mathrm{~cm}$ & $15 \mathrm{my}$ & Poland \\
\hline
\end{tabular}


Appendix I - p. 197 - Results of an interview, regarding the paper source and cup conversion origin of disposable hot beverage paper cups, with five FSD cup purchasers.

\begin{tabular}{|c|c|c|c|}
\hline \multicolumn{4}{|c|}{ 4oz Hot Beverage Category } \\
\hline Reference & Paper Source & Paper Type & Cup Converter \\
\hline HC-007pj & Stora Enso & $230 / 15$ & Benders \\
\hline HC-041pj & Sun & $210 / 18$ & Anbao \\
\hline HC-105pj & Sun & 210/30PLA & Nanda \\
\hline HC-123pj & MWV & $230 / 18$ & Ekol \\
\hline HC-130pj & Sun & $210 / 18$ & Nanda \\
\hline HC-159pj & Stora Enso & $230 / 15$ & Huhtamaki \\
\hline HC-170pj & Stora Enso & $230 / 15$ & Seda \\
\hline HC-171pj & APP & $230 / 18$ & Lamican \\
\hline HC-176pj & USA source & $230 / 18$ & \begin{tabular}{|l|} 
Solo \\
\end{tabular} \\
\hline HC-189pj & Sun & 230/18 & GreenPaperCup \\
\hline HC-147pj & Stora Enso & $210 / 18$ & \begin{tabular}{|l|} 
Ekol \\
\end{tabular} \\
\hline HC-114pj & Sun & $230 / 18$ & Anbao \\
\hline
\end{tabular}

\begin{tabular}{l|l|l|l}
\multicolumn{4}{l}{ 6oz Hot Beverage Category } \\
\hline \multicolumn{1}{l}{ Reference } & Paper Source & Paper Type & Cup Converter \\
\hline HC-008pj & Stora Enso & $210 / 18$ & Benders \\
\hline HC-098pj & Sun & $280 / 18$ & Nanda \\
\hline HC-115pj & Sun & $230 / 18$ & Anbao \\
\hline HC-131pj & Sun & $210 / 18$ & Nanda \\
\hline HC-174pj & APP & $250 / 18$ & Lamican \\
\hline HC-203pj & APP & $190 / 18$ & Lamican \\
\hline HC-194pj & Sun & $220 / 18$ & GreenPaperCup \\
\hline HC-154.1pj & APP & $200 / 18$ & Lamican \\
\hline HC-183.1pj & Nippon & $220 / 18$ & GreenPaperCup \\
\hline HC-053pj & Sun & $210 / 18$ & Anbao \\
\hline HC-124pj & MWV & $230 / 30 P L A$ & PPI \\
\hline HC-148pj & MWV & $210 / 30 P L A$ & PPI \\
\hline HC-150.1pj & PlantPaper & $210 / 35 P L A$ & Weimon \\
\hline
\end{tabular}

\section{5oz Hot Beverage Category}

\begin{tabular}{|c|c|c|c|}
\hline Reference & Paper Source & Paper Type & Cup Converter \\
\hline HC-009pj & Stora Enso & $210 / 18$ & Benders \\
\hline HC-035pj & Nippon & $280 / 18$ & Nanofiber \\
\hline HC-093pj & MWV & $230 / 18$ & Ekol \\
\hline HC-104pj & Sun & $210 / 18$ & Whywin \\
\hline HC-125pj & APP & $230 / 18$ & Lamican \\
\hline $\mathrm{HC}-128 \mathrm{pj}$ & Sun & $230 / 18$ & Anbao \\
\hline HC-149pj & MWV & $224 / 18$ & Ekol \\
\hline HC-209pj & USA source & $210 / 18$ & Lanca \\
\hline HC-106pj & Sun & $210 / 30 P L A$ & Nanda \\
\hline HC-082pj & Sun & $210 / 18$ & Anbao \\
\hline HC-032.1pj & Sun & $210 / 18$ & KingGarden \\
\hline $\mathrm{HC}-034,1 \mathrm{pj}$ & Sun & $210 / 18$ & EarthSave \\
\hline HC-037.1pj & Evergreen & $200 / 18$ & GreenPaperCup \\
\hline HC-195.1pj & Sun & $210 / 30 P L A$ & GreenPaperCup \\
\hline HC-151.1pj & PlantPaper & $210 / 30 P L A$ & Weimon \\
\hline
\end{tabular}

\begin{tabular}{l|l|l|l}
\hline \multicolumn{1}{l}{ 8oz Hot Beverage Category } \\
\hline \multicolumn{1}{l}{ Reference } & \multicolumn{1}{l}{ Paper Source } & \multicolumn{1}{l}{ Paper Type } & \multicolumn{1}{l}{ Cup Converter } \\
\hline HC-017pj & Sun & $280 / 30 P L A$ & GreenPaperCup \\
\hline HC-029pj & Sun & $280 / 18$ & Anbao \\
\hline HC-036pj & Nippon & $280 / 18$ & GreenPaperCup \\
\hline HC-099pj & Sun & $300 / 18$ & Pando \\
\hline HC-107pj & Sun & $280 / 30 P L A$ & Pando \\
\hline HC-126pj & MWV & $250 / 18$ & Ekol \\
\hline HC-140pj & MWV & $280 / 18$ & Ekol \\
\hline HC-152pj & Stora Enso & $250 / 18$ & Huhtamaki \\
\hline HC-157pj & Stora Enso & $300 / 18$ & Seda \\
\hline HC-196pj & Sun & $215 / 30 P L A$ & Green Paper \\
\hline HC-208pj & USA & $308 / 18$ & Moducup \\
\hline HC-211pj & Evergreen & $265 / 18$ & GreenPaperCup \\
\hline HC-012pj & Stora Enso & $280 / 18$ & Benders \\
\hline HC-014pj & Stora Enso & $250 / 18$ & Benders \\
\hline HC-202pj & Sun & $250 / 18$ & Pando \\
\hline HC-133.1pj & Sun & $280 / 18$ & Pando \\
\hline HC-191.1pj & Nippon & $250 / 18$ & GreenPaperCup \\
\hline HC-188.1pj & Sun & $250 / 18$ & GreenPaperCup \\
\hline HC-116,1pj & Sun & $300 / 18$ & Anbao \\
\hline HC-025.1pj & Sun & $320 / 18$ & Anbao \\
\hline
\end{tabular}

\begin{tabular}{l|l|l|l}
\hline \multicolumn{1}{l}{ 10oz Hot Beverage Category } \\
\multicolumn{1}{l}{ Reference } & \multicolumn{1}{l}{ Paper Source } & \multicolumn{1}{l}{ Paper Type } & Cup Converter \\
\hline HC-038pj & Sun & $300 / 18$ & Anbao \\
\hline HC-136pj & USA source & $308 / 18$ & Lanca \\
\hline HC-175pj & APP & $312 / 18$ & Lamican \\
\hline HC-199pj & Stora Enso & $250 / 18$ & Huhtamaki PL \\
\hline HC-158pj & Stora Enso & $310 / 18$ & Huhtamaki UK \\
\hline HC-192pjV1 & Nippon & $280 / 18$ & GreenPaperCup \\
\hline HC-030pj & Sun & $280 / 18$ & Anbao \\
\hline HC-006.1pj & Stora Enso & $310 / 18$ & Benders \\
\hline
\end{tabular}

\begin{tabular}{l|l|l|l}
\hline \multicolumn{4}{c}{ 12oz Hot Beverage Category } \\
\hline Reference & Paper Source & \multicolumn{1}{l}{ Paper Type } & Cup Converter \\
\hline HC-013pj & Stora Enso & $280 / 18$ & Benders \\
\hline HC-031pj & Sun & $280 / 18$ & Anbao \\
\hline HC-108pj & Sun & $300 / 30 P L A$ & Nanda \\
\hline HC-117pj & Sun & $320 / 18$ & Anbao \\
\hline HC-127pj & MWV & $350 / 18$ & Ekol \\
\hline HC-137pj & Billerud & & De Jong \\
\hline HC-135pj & USA source & $308 / 18$ & Lanca \\
\hline HC-172pj & APP & $280 / 18$ & Lamican \\
\hline HC177pj & Stora Enso & $280 / 18$ & Huhtamaki \\
\hline HC193pj & Nippon & $254 / 18$ & GreenPaperCup \\
\hline HC-134.1pj & Sun & $320 / 18$ & Nanda \\
\hline
\end{tabular}


Appendix J - p. 223 - Calculations related to percentage waste figures in paper plate manufacturing.

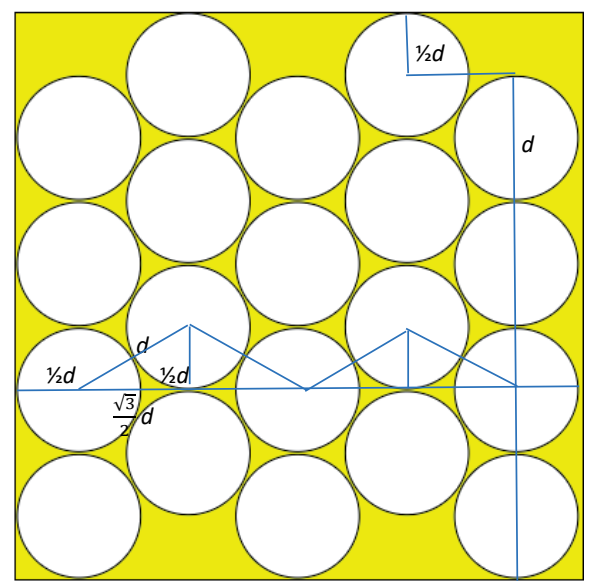

$d=$ the diameter of the plate

The width of the sheet is calculated using Pythagorus' theorem:

$=\frac{1}{2} d+4\left(\frac{\sqrt{3}}{2}\right) d+\frac{1}{2} d=(1+2 \sqrt{3}) d=4.464 d$

For the circle layout within a sheet (Figure 10.5):

the length of the sheet $=\left(4+\frac{1}{2}\right) d=4.5 d$,

therefore, the area of the sheet $=4.464 d \times 4.5 d=20.09 d^{2}$.

There are 20 plates on the sheet, each of area $\pi\left(\frac{d}{2}\right)^{2}$,

so the total plate area $=20 \times \pi\left(\frac{d}{2}\right)^{2}=15.71 d^{2}$.

The waste fraction is therefore $\frac{20.09-15.71}{20.09}=0.218$ or $21.8 \%$.

For the circle layout within a roll (Figure 10.6):

There are 22.5 plates in the equivalent of the sheet area $20.09 d^{2}$, each of area $\pi\left(\frac{d}{2}\right)^{2}$,

so the total plate area $=22.5 \times \pi\left(\frac{d}{2}\right)^{2}=17.67 d^{2}$

The waste fraction is therefore $\frac{20.09-17.67}{20.09}=0.120$ or $12 \%$.

NB: These calculations are presuming perfectly touching circles and an infinite roll length. There will be inevitable extra waste in practice; the cutters will leave some material between cut plates, and there will be some more waste at the roll ends. 
Appendix K - p. 248 - Details related to this range of glasses studied in Chapter 11.

\begin{tabular}{|c|c|c|c|c|c|}
\hline Code & Weight (g) & Material/ Process & Source & Country of Origin & Printed? \\
\hline GLASS-01 & 6.47 & PET & COVERIS-NL & Poland & no \\
\hline GLASS-02 & 6.51 & PET & COVERIS-NL & Poland & no \\
\hline GLASS-03 & 5.81 & PET & COVERIS-NL & Poland & no \\
\hline GLASS-04 & 5.76 & PS THERMO & Italy & Italy & no \\
\hline GLASS-05 & 6.18 & PET & Poland & Poland & no \\
\hline GLASS-06 & 12.81 & PS INJ & HOMELINK & China & yes \\
\hline GLASS-07 & 12.81 & PS INJ & HOMELINK & China & yes \\
\hline GLASS-09 & 14.46 & PS INJ & China & China & yes \\
\hline GLASS-10 & 6.31 & PS THERMO & Spain & Spain & yes \\
\hline GLASS-11 & 10.11 & PS INJ & Romania & Romania & no \\
\hline GLASS-12 & 6.51 & PET & COVERIS-NL & Poland & no \\
\hline GLASS-13 & 5.72 & PS THERMO & Italy & Italy & no \\
\hline GLASS-14 & 5.24 & PLA & Taiwan & Taiwan & no \\
\hline GLASS-15 & 4.51 & PLA & Taiwan & Taiwan & no \\
\hline GLASS-16 & 5.16 & PLA & Taiwan & Taiwan & no \\
\hline GLASS-17 & 6.20 & PLA & Taiwan & Taiwan & no \\
\hline GLASS-18 & 8.72 & PLA & Taiwan & Taiwan & no \\
\hline GLASS-19 & 10.83 & PLA & Taiwan & Taiwan & no \\
\hline GLASS-20 & 6.50 & PLA & Germany & Germany & yes \\
\hline GLASS-21 & 4.53 & PLA & Germany & Germany & no \\
\hline GLASS-22 & 6.50 & PLA & Germany & Germany & no \\
\hline GLASS-23 & 4.53 & PLA & Germany & Germany & yes \\
\hline GLASS-24 & 12.11 & PLA & GOLDFLAG & Taiwan & no \\
\hline GLASS-25 & 10.08 & PLA & GOLDFLAG & Taiwan & no \\
\hline GLASS-26 & 6.51 & PET & COVERIS-NL & Poland & no \\
\hline GLASS-27 & 4.28 & PS THERMO & COVERIS-NL & Netherlands & no \\
\hline GLASS-28 & 6.51 & PET & COVERIS-NL & Poland & no \\
\hline GLASS-29 & 5.81 & PET & HELIOS-NL & Netherlands & no \\
\hline GLASS-30 & 6.40 & PET & AMHIL & Poland & yes \\
\hline GLASS-31 & 4.28 & PS THERMO & COVERIS-NL & Bulgaria & no \\
\hline GLASS-32 & 2.71 & PP & FLO ITALIA & Italy & no \\
\hline GLASS-33 & 6.51 & PET & COVERIS-NL & Poland & no \\
\hline GLASS-34 & 4.36 & $\mathrm{PP}$ & KREIS - BRD & Germany & no \\
\hline GLASS-35 & 5.96 & PET & COVERIS-NL & Poland & yes \\
\hline GLASS-36 & 8.16 & PS THERMO & HUHTAMAKI & Germany & no \\
\hline
\end{tabular}




\begin{tabular}{|c|c|c|c|c|c|}
\hline Code & Weight (g) & Material/ Process & Source & Country of Origin & Printed? \\
\hline GLASS-37 & 3.19 & PS THERMO & HUHTAMAKI & Germany & no \\
\hline GLASS-38 & 6.07 & PET & COVERIS-NL & Poland & no \\
\hline GLASS-39 & 11.56 & PET & COVERIS-NL & Poland & no \\
\hline GLASS-40 & 12.86 & PET & AMHIL & Poland & no \\
\hline GLASS-41 & 4.48 & PS THERMO & FLO ITALIA & Italy & no \\
\hline GLASS-42 & 9.67 & PS INJ & DESTER & Belgium & no \\
\hline GLASS-43 & 4.99 & PS THERMO & FLO ITALIA & Italy & no \\
\hline GLASS-44 & 12.79 & PS INJ & DESTER & Belgium & no \\
\hline GLASS-45 & 12.69 & PS INJ & $\begin{array}{c}\text { SCHAEGNER } \\
\text { BRD }\end{array}$ & Germany & no \\
\hline GLASS-46 & 5.72 & PET & COVERIS-NL & Poland & no \\
\hline GLASS-47 & 6.51 & PET & COVERIS-NL & Poland & no \\
\hline GLASS-48 & 5.63 & PET & COVERIS-NL & Poland & no \\
\hline GLASS-49 & 5.79 & PET & COVERIS-NL & Poland & no \\
\hline GLASS-50 & 4.42 & PP & COVERIS-NL & Poland & no \\
\hline GLASS-51 & 6.51 & PET & COVERIS-NL & Poland & no \\
\hline GLASS-52 & 6.10 & PET & COVERIS-NL & Poland & no \\
\hline GLASS-53 & 5.93 & PP & COVERIS-NL & Poland & no \\
\hline GLASS-54 & 7.64 & PET & COVERIS-NL & Poland & no \\
\hline GLASS-55 & 4.43 & PP & PROPAC & Germany & yes \\
\hline GLASS-57 & 4.45 & PP & COVERIS-NL & Poland & yes \\
\hline GLASS-58 & 4.17 & PP & PROPAC & Germany & yes \\
\hline GLASS-59 & 4.20 & PP & PROPAC & Germany & yes \\
\hline GLASS-60 & 6.53 & PET & COVERIS-NL & Poland & yes \\
\hline GLASS-61 & 4.60 & PP & COVERIS & Poland & yes \\
\hline GLASS-62 & 7.52 & PP & COVERIS & Poland & yes \\
\hline GLASS-63 & 8.06 & PP & COVERIS & Poland & yes \\
\hline GLASS-64 & 13.92 & PET & COVERIS & Poland & yes \\
\hline GLASS-65 & 7.52 & $\mathrm{PP}$ & COVERIS & Poland & yes \\
\hline GLASS-66 & 4.90 & PP & COVERIS & Poland & yes \\
\hline GLASS-67 & 4.60 & $\mathrm{PP}$ & COVERIS & Poland & yes \\
\hline GLASS-68 & 4.33 & PP & PROPAC & Germany & no \\
\hline GLASS-69 & 4.45 & PP & COVERIS & Poland & yes \\
\hline GLASS-70 & 5.52 & PLA & HUHTAMAKI & Germany & yes \\
\hline GLASS-71 & 5.52 & PLA & HUHTAMAKI & Germany & yes \\
\hline GLASS-72 & 5.52 & PLA & HUHTAMAKI & Germany & yes \\
\hline GLASS-73 & 4.59 & PLA & HUHTAMAKI & Germany & yes \\
\hline
\end{tabular}


Appendix L - p. 271 - Discussion with carton product purchasing experts regarding carton board source. These experts differ from those in the above FSD purchasing list, they are:

- Michel de Man - Paardekooper

- Anne Waalewijn - Van der Windt

- Agnieszka van Batavia - Pacombi Group

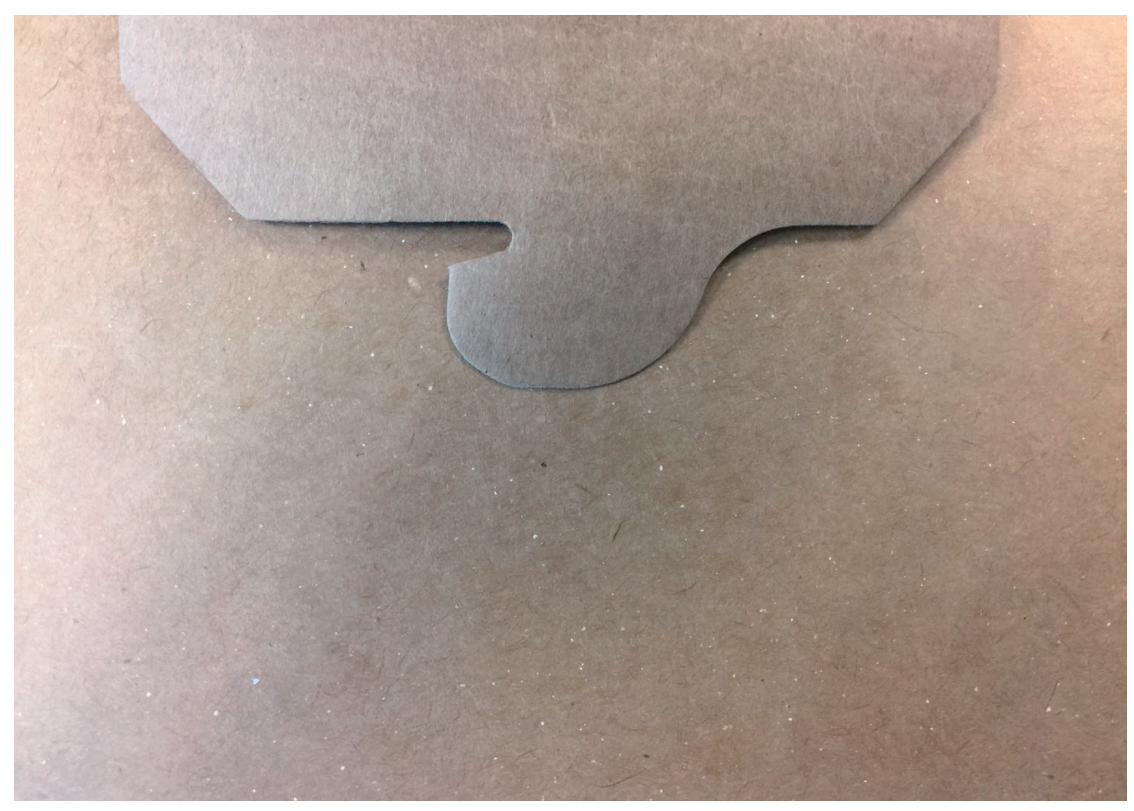

Anne Waalewijn stated "I recognized the color of the board in combination with the white "specks" in it. I had seen this earlier in a project where this USA board was used". Agnieszka van Batavia confirm with the same reasoning as Anne Waalewijn. Michel de Man could not make the same direct reasoning but then supported the statement made by Anne. 
Appendix M - p. 280 - The names in alphabetical order, of the five experts who participated in the expert interviews in Chapter 12.

- $\quad$ Bernd Brandt - Denkstatt - Senior Consultant, DI

- Mark Goedkoop - PRé Consultants - Founder

- $\quad$ Leigh Holloway, PhD - ECO3 Design Ltd - Senior Consultant

- $\quad$ Prof. José Potting, PhD - PBL Netherlands Environmental Assessment Agency

- Jasper Scholten - Blonk Consultants - Manager Life Cycle Assessment 
Appendix $\mathbf{N}$ - p. 280 - The questionnaire sent to each of the experts interviewed in Chapter 12, or used when conducting a face-to-face interview.

\section{Introduction}

When comparing the environmental impact of a category of like functionality products it was often noted that product stakeholders were not engaged in the process as they were either unknown, not consulted, or uncooperative when they were consulted. This would seem to be a common problem when comparing many of the simple fit-for-purpose type items in our lives, such as food service disposables.

In an era in which the use of LCA based comparative environmental claims is increasing, it would appear that attempting to account for the environmental performance of these simple products is at risk of being limited due to absent stakeholders.

The absence of stakeholders would indicate that product economic inventory data would be missing for input to an LCA study. Various previous LCAs identified in my research had inventory compiled from a purely visual assessment of the product, often with a lack of technologically relevant knowledge, with assumptions and subjective choices.

My curiosity was if this issue could be addressed so as to be able to identify objective product economic inventory input for such a comparative LCA based study without the product stakeholders. Could a method be developed that increased objectivity and accuracy with regard to the product inventory input data to an LCA? What affect would such a method have on the relative position of a product in a rank order of environmental merit?

Research showed that such a method would need to take account of:

1. measuring the product's functional specifications to identify if the product meets the requirements of the functional unit

2. identifying the materials composition and their associated conversion processes

3. identifying the product's countries of manufacture

4. the availability of technologically relevant knowledge relating to the products under study

In the text the term "Visual study" refers to a largely visual type inventory identification of the product, as could likely be made by an LCA generalist. The term "Detailed study" then refers to a study involving laboratory instrumentation, product market/sector knowledge and product technologically relevant knowledge, to address the above points 1., 2., 3. and 4. The research is not exhaustive as regards the analytical methods that could be used to identify inventory.

To test the effects in developing the method and to understand if a Visual study produces different results than a Detailed study, secondary LCIA data was used and a ReCiPe 
endpoint figure was established for each product within the like functionality category, ReCiPe being chosen due to its common usage in LCA. The products were then rank ordered based on the end point figures, with the product best in category ranked 1, achieving the lowest endpoint figure. It should be noted that this study is not a further study into LCA methodology and purely focuses on the product economic inventory collection part of the LCA process. The choice of LCIA methodology and LCA tool used in the study are purely to test the effect of the method.

A single page description of the method as relates to each of the above four listed points, 1. to 4., is attached. Please kindly read each section and answer the questionnaire at the end of each section. Please also kindly provide an overall summary at the end. Thank you in advance.

\section{Functional Unit}

Functional specification rules are required against which a product must comply to meet the functional unit in the comparative study. In such a study, without stakeholders, it would appear most objective to make sure that the intended function of an individual product is fully represented, without reducing the category to an unworkably small number of products. Although the initial choice of a category functional specification may be subjective, its rules should be able to be objectively verified.

An example is taken of a category of disposable forks, of the type that might be used at a barbecue event, all with a very similar size and weight. They are measured for their break force using a Universal Testing Instrument with the appropriate jig (see the figure below). It was identified that the Demo fork had half the strength of the average of the other forks in the category, even though all the fork weights and sizes were very similar.

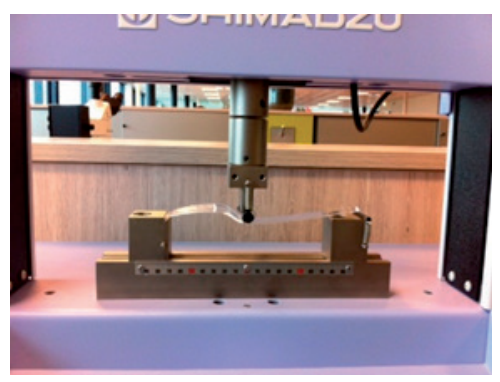


In the table below the effect of inclusion and removal of the Demo fork can be seen as relates to the rank order of the forks within the category:

\begin{tabular}{c|c|c}
\hline \multicolumn{2}{c}{ Visual Approach Fork Category } \\
\hline Forks & $\begin{array}{c}\text { ReCiPe } \\
\text { Endpoints }\end{array}$ & $\begin{array}{c}\text { Rank } \\
\text { Order }\end{array}$ \\
\hline 1 & 0.00322 & 1 \\
\hline 2 & 0.00395 & 2 \\
\hline 3 & 0.00460 & 6 \\
\hline 4 & 0.00507 & 8 \\
\hline 5 & 0.00505 & 7 \\
\hline 6 & 0.00438 & 5 \\
\hline 7 & 0.00437 & 4 \\
\hline Demo & $\mathbf{0 . 0 0 3 9 8}$ & $\mathbf{3}$ \\
\hline
\end{tabular}

\begin{tabular}{c|c|c}
\hline \multicolumn{2}{c}{ Detailed Approach Fork Category } \\
\hline Forks & $\begin{array}{c}\text { ReCiPe } \\
\text { Endpoints }\end{array}$ & $\begin{array}{c}\text { Rank } \\
\text { Order }\end{array}$ \\
\hline 1 & 0.00322 & 1 \\
\hline 2 & 0.00395 & 2 \\
\hline 3 & 0.00460 & 5 \\
\hline 4 & 0.00507 & 7 \\
\hline 5 & 0.00505 & 6 \\
\hline 6 & 0.00438 & 4 \\
\hline 7 & 0.00437 & 3 \\
\hline Demo & - & - \\
\hline
\end{tabular}

Both the average strength of the fork category and the exclusion of the Demo fork from this category can be objectively established using testing instrumentation. A large range of instrument based tests could be carried out to establish objective compliance with a category; examples being, for instance, proof of insulation, fill capacity, cup wall stiffness, compression strength, etc.

\section{Functional Unit - Questionnaire}

This page lists the questions to be answered as relates to the text regarding the Functional Unit.

1. Do you feel this method would contribute to establishing a category's functional specification, for the functional unit in a comparative study without stakeholders? 
2. Do you feel it provides an objective method for establishing the products within a category? If not, where do you see the limitations?

3. Do you have any suggestions as to how the method could be enhanced to improve objective identification of product functionality specifications for comparative studies in the absence of stakeholders? 


\section{Material Composition}

Once products have been identified as compliant to the category functional specification rules their materials composition, both qualified and quantified needs to be inventoried. Various analytical instrumentation such as spectroscopy can identify the Detailed inventory where this would not be possible using a Visual study.

In the table below a study is made of 26 disposable plates. The effect of taking a Visual approach to inventory compared to a Detailed approach can be seen in the table below in which the last plate moves from 12th in rank order to 9th in rank order.

Visual Product Inventory Approach

\begin{tabular}{c|c|c}
\hline \multicolumn{1}{c}{ PL22 Plates } & \multicolumn{1}{c}{$\begin{array}{c}\text { ReCiPe } \\
\text { Endpoints }\end{array}$} & \multicolumn{1}{c}{ Rank Order } \\
\hline 1 & 0.00534 & 14 \\
\hline 2 & 0.00560 & 15 \\
\hline 3 & 0.00849 & 22 \\
\hline 4 & 0.00667 & 17 \\
\hline 5 & 0.00766 & 20 \\
\hline 6 & 0.00766 & 21 \\
\hline cont'd & cont'd & cont'd \\
\hline 22 & 0.00156 & 1 \\
\hline 23 & 0.00222 & 7 \\
\hline 24 & 0.00174 & 2 \\
\hline 25 & 0.00376 & 11 \\
\hline Visual & $\mathbf{0 . 0 0 4 7 8}$ & $\mathbf{1 2}$ \\
\hline
\end{tabular}

Detailed Product Inventory Approach

\begin{tabular}{c|c|c}
\hline PL22 Plates & \multicolumn{1}{c}{$\begin{array}{c}\text { ReCiPe } \\
\text { Endpoints }\end{array}$} & Rank Order \\
\hline 1 & 0.00534 & 14 \\
\hline 2 & 0.00560 & 15 \\
\hline 3 & 0.00849 & 22 \\
\hline 4 & 0.00667 & 17 \\
\hline 5 & 0.00766 & 20 \\
\hline 6 & 0.00766 & 21 \\
\hline cont'd & cont'd & cont'd \\
\hline 22 & 0.00156 & 1 \\
\hline 23 & 0.00222 & 7 \\
\hline 24 & 0.00174 & 2 \\
\hline 25 & 0.00376 & 12 \\
\hline Detailed & $\mathbf{0 . 0 0 2 7 8}$ & $\mathbf{9}$ \\
\hline
\end{tabular}

The Visual approach, in the above table, adopted 100\% polypropylene as the material inventory for the Visual plate. The Detailed approach identified that the Detailed plate was a composite of $47.5 \% \mathrm{PP}, 50 \% \mathrm{CaCO}_{3}$ and $2.5 \% \mathrm{TiO}_{2}$. The Detailed approach used spectroscopy, density analysis and stoichiometric chemistry.

With technologically relevant knowledge, identification of material components also acts to identify their associated processing and manufacturing operations used to transform the material into the finished product, further enhancing the inventory for LCA input. In the case above the Visual approach might assume extrusion and thermoforming as the processing types, in the case of a Detailed approach it becomes necessary to also include the processes of drying and compounding. 
This analytical instrumentation approach may also further contribute to the identification of other aspects of product inventory such as evident country of origin, as is covered in the next page.

\section{Material Composition - Questionnaire}

This page lists the questions to be answered as relates to the text regarding the Material Composition.

1. Do you feel this method would contribute to the relevance, objectivity and quality of product economic inventory collect for LCA input?

2.If not, where do you see the limitations? 
3. Do you have any suggestions as to how the method could be enhanced to improve product economic inventory identification?

\section{Country of Origin}

Knowledge of the source of materials and finished products could contribute to identifying the energy sources, transport types and transport distances.

Identifying the country of origin requires the use of spectroscopy, up-to-date product libraries and expert knowledge as regards the sector related to the product types. Product sources can be identified from markings on the product and its associated packaging, spectra comparison of the various components and the expert knowledge to interpret this information. An example of this is the way the police identify the source of drugs from the packaging to a level that is "beyond reasonable doubt".

In the table below a study is made of 26 disposable plates. The demonstration plate is compared based on production in France and China to show the rank order change derived from these two country of origin changes. This significant change in rank order would indicate the importance of identifying the country of origin of a product for which the stakeholder was absent. 
French Demonstration Plate

\begin{tabular}{c|c|c}
\hline \multirow{2}{*}{ PL22 Plates } & $\begin{array}{c}\text { ReCiPe } \\
\text { Endpoints }\end{array}$ & Rank Order \\
\hline 1 & 0.00534 & 14 \\
\hline 2 & 0.00560 & 15 \\
\hline 3 & 0.00849 & 22 \\
\hline 4 & 0.00667 & 17 \\
\hline 5 & 0.00766 & 20 \\
\hline 6 & 0.00766 & 21 \\
\hline cont'd & cont'd & cont'd \\
\hline 22 & 0.00156 & 1 \\
\hline 23 & 0.00222 & 7 \\
\hline 24 & 0.00174 & 2 \\
\hline 25 & 0.00376 & 11 \\
\hline France & $\mathbf{0 . 0 0 4 7 8}$ & $\mathbf{1 2}$ \\
\hline
\end{tabular}

Chinese Demonstration Plate

\begin{tabular}{c|c|c}
\hline \multirow{2}{*}{ PL22 Plates } & $\begin{array}{c}\text { ReCiPe } \\
\text { Endpoints }\end{array}$ & Rank Order \\
\hline 1 & 0.00534 & 13 \\
\hline 2 & 0.00560 & 14 \\
\hline 3 & 0.00849 & 21 \\
\hline 4 & 0.00667 & 16 \\
\hline 5 & 0.00766 & 19 \\
\hline 6 & 0.00766 & 20 \\
\hline cont'd & cont'd & cont'd \\
\hline 22 & 0.00156 & 1 \\
\hline 23 & 0.00222 & 7 \\
\hline 24 & 0.00174 & 2 \\
\hline 25 & 0.00376 & 11 \\
\hline China & $\mathbf{0 . 0 0 9 3 3}$ & $\mathbf{2 3}$ \\
\hline
\end{tabular}

\section{Country of Origin - Questionnaire}

This page lists the questions to be answered as relates to the text regarding the country of origin.

1. Do you feel these methods could contribute to the identification of the country of origin of a product and hence enhance the objectivity and quality of a comparative study in the absence of stakeholders? 
2. If not, where do you see the limitations?

3. Do you have any suggestions as to how this approach could be enhanced to improve identification of a product's country of origin? 


\section{Technologically Relevant Knowledge}

Research shows that the lack of product technologically relevant knowledge is a common critique of LCA. Interpretation of the inventory derived from the proposed method requires product technologically relevant knowledge as well as further support from market and sector related knowledge.

On page 14 of the Plastic ZERO - Public Private Cooperation's for Avoiding Plastic as a Waste- LCA study into "Comparing disposal versus reuse of food packaging" for various cities public procurement, such as Copenhagen and Malmo, thermoforming was erroneously chosen in the LCA as the method to make plastic cutlery, where such items are actually made using injection moulding techniques.

If thermoforming is used in place of injection moulding the associated energy requirement for thermoforming would be lower than for injection moulding. Cutlery is often made in Asian countries such as China whose electricity is listed as having a relatively high environmental impact. Therefore, it is possible that the differences in impacts of this energy use can make a considerable difference to the overall life cycle impact of a given product.

In the table below, for the Demo fork, the correct choice of injection moulding is adopted, and the Demo fork is ranked 3rd in the category. When the incorrect choice of thermoforming is adopted, as in the case of Demo 1 fork below, it is ranked 1st in the category.

\begin{tabular}{c|c|c}
\hline \multicolumn{3}{c}{ Demo = Injection Moulded } \\
\hline Forks & $\begin{array}{c}\text { ReCiPe End- } \\
\text { points }\end{array}$ & Rank Order \\
\hline 1 & 0.00226 & 1 \\
\hline 2 & 0.00246 & 2 \\
\hline 3 & 0.00286 & 6 \\
\hline 4 & 0.00316 & 8 \\
\hline 5 & 0.00314 & 7 \\
\hline 6 & 0.00273 & 5 \\
\hline 7 & 0.00257 & 4 \\
\hline Demo & $\mathbf{0 . 0 0 2 4 8}$ & $\mathbf{3}$ \\
\hline
\end{tabular}

\begin{tabular}{c|c|c}
\hline \multicolumn{3}{c}{ Demo 1 = Thermoformed } \\
\hline Forks & $\begin{array}{c}\text { ReCiPe End- } \\
\text { points }\end{array}$ & Rank Order \\
\hline 1 & 0.00226 & 2 \\
\hline 2 & 0.00246 & 3 \\
\hline 3 & 0.00286 & 6 \\
\hline 4 & 0.00316 & 8 \\
\hline 5 & 0.00314 & 7 \\
\hline 6 & 0.00273 & 5 \\
\hline 7 & 0.00257 & 4 \\
\hline Demo 1 & $\mathbf{0 . 0 0 1 6 1}$ & $\mathbf{1}$ \\
\hline
\end{tabular}

\section{Technologically Relevant Knowledge - Questionnaire}

This page lists the questions to be answered as relates to the text on page 8 regarding Technologically Relevant Knowledge. 
1. Do you feel that LCA operatives should most ideally be those with the technologically relevant knowledge as relates to the products under study?

2. Would this contribute to the relevance, objectivity and quality of product economic inventory collect for LCA input? 
3. If not, where do you see the limitations?

4. Do you have any suggestions, as relates to product knowledge, which could contribute to improving product economic inventory identification? 


\section{Overall Summary}

Please kindly provide an overall summary of your thoughts as regards the contribution that the use of analytical instrumentation and technologically relevant knowledge could have on improving the quality of product economic inventory for use in comparative LCA studies in the absence of stakeholders. Plus any other issues which you believe should be considered and/or researched with regard to the collection of product economic inventory data destined for use in a comparative LCA. 


\section{Abbreviations}

\begin{tabular}{|c|c|}
\hline ASTM & American Society for Testing Materials \\
\hline ALO & Agricultural Land Occupation \\
\hline ALOP & Agricultural Land Occupation Potential \\
\hline aPET & amorphous Polyethylene Terephthalate \\
\hline $\mathrm{B} 2 \mathrm{~B}$ & Business to Business \\
\hline $\mathrm{B} 2 \mathrm{C}$ & Business to Consumer \\
\hline BBC & British Broadcasting Corporation \\
\hline BOPP & Biaxially Oriented Polypropylene \\
\hline BRE & Building Research Establishment \\
\hline BUWAL & Department for the Environment (Germany) \\
\hline CBS & Central Bureau for Statistics \\
\hline $\mathrm{CC}$ & Climate Change \\
\hline CCILC & Chinese Chamber of Commerce and Industry \\
\hline CE marking & EU Conformity Mark (French) \\
\hline CED & Cumulative Energy Demand \\
\hline CES & Cambridge Engineering Selector \\
\hline CFC & Chlorofluorocarbon \\
\hline CML & Institute of Environmental Sciences (Netherlands) \\
\hline $\mathrm{CO}_{2}$ & Carbon Dioxide \\
\hline $\mathrm{CO}_{2} \mathrm{e}$ & Carbon Dioxide equivalent \\
\hline $\mathrm{CoO}$ & Country of Origin \\
\hline COP21 & Climate Change Conference Paris \\
\hline CPA & Classification of Product by Activity \\
\hline CPC & Central Product Classification \\
\hline $\mathrm{CRQ}$ & Central Research Question \\
\hline DALYS & Disability-adjusted life years \\
\hline $\mathrm{DCB}$ & Dichlorobenzene \\
\hline Defra & Department for the Environment, Food and Rural Affairs (UK) \\
\hline DFE & Department for the Environment \\
\hline DIN & German Industry Standards \\
\hline DWC & Double Wall Cup \\
\hline ECS & Environmental Claim Statement \\
\hline EF & Environmental Footprint \\
\hline EIA & Environmental Impact Assessment \\
\hline ELCD & European Life Cycle Data \\
\hline
\end{tabular}




\begin{tabular}{|c|c|}
\hline ELCRL & Environmental Life-Cycle Rating Label \\
\hline EMAS & Eco-Management Audit Scheme \\
\hline EoL & End of Life \\
\hline EPD & Environmental Product Declaration \\
\hline EPS & Expanded Polystyrene \\
\hline Eq & Equivalent \\
\hline EU & European Union \\
\hline FD & Fossil Resource Depletion \\
\hline FDA & Food and Drug Administration (USA) \\
\hline FDP & Fossil Depletion Potential \\
\hline $\mathrm{Fe}$ & Iron \\
\hline FE & Freshwater Eutrophication \\
\hline FEP & Freshwater Eutrophication Potential \\
\hline FET & Freshwater Ecotoxicity \\
\hline FETP & Freshwater Ecotoxicity Potential \\
\hline FS & Functional Specification \\
\hline FSC & Forest Stewardship Council \\
\hline FSD & Food Service Disposables \\
\hline FSIN & Food Service Institute Netherlands \\
\hline FSR & Full Service Restaurant \\
\hline FSR & Functional Specification Rules \\
\hline FTIR & Fourier Transform Infrared \\
\hline FU & Functional Unit \\
\hline FUMCO & Functional Unit, Material Composition, Origin \\
\hline GDP & Gross Domestic Product \\
\hline GIGO & Garbage in Garbage out \\
\hline GLO & Global (re CoO Ecoinvent) \\
\hline GPPS & General Purpose Polystyrene \\
\hline GWP & Global Warming Potential \\
\hline HDT & Heat Deflection Temperature \\
\hline HORECA & Hotel, Restaurant, Café \\
\hline HT & Human Toxicity \\
\hline HTP & Human Toxicity Potential \\
\hline |APRI & International Association of Packaging Research Institutes \\
\hline ICC & International Chamber of Commerce \\
\hline IEEE & Institute of Electrical and Electronic Engineers \\
\hline ILCD & International Reference Life Cycle System \\
\hline IMF & International Monetary Fund \\
\hline
\end{tabular}




\begin{tabular}{|c|c|}
\hline IPCC & International Panel on Climate Change \\
\hline IR & Ionizing Radiation \\
\hline IRMS & Isotope Ratio Mass Spectrometry \\
\hline IRP & Ionizing Radiation Potential \\
\hline ISO & International Organization for Standardization \\
\hline IVAM & University of Amsterdam LCA Database \\
\hline LCA & Life Cycle Assessment \\
\hline $\mathrm{LCl}$ & Life Cycle Inventory \\
\hline LCIA & Life Cycle Inventory Assessment \\
\hline LPB & Liquid Packaging Board \\
\hline$m^{2} a$ & Metre Squared per Annum \\
\hline MC & Material Composition \\
\hline MDP & Mineral Depletion Potential \\
\hline ME & Marine Eutrophication \\
\hline MEEuP (EU) & Methodology for Eco-Design of Energy Related Products \\
\hline MEP & Marine Eutrophication Potential \\
\hline MET & Marine Ecotoxocity \\
\hline METP & Marine Ecotoxocity Potential \\
\hline MJEq & Mega Joule Equivalent \\
\hline MRD & Mineral Resource Depletion \\
\hline N & Nitrogen \\
\hline NACE & Statistical Classification of Economic Activities in the European Union \\
\hline NFI & Netherlands Forensic Institute \\
\hline NGO & Non-Governmental Organization \\
\hline NLT & Natural Land Transformation \\
\hline NLTP & Natural Land Transformation Potential \\
\hline NMVOC & Non-methane Volatile Organic Compound \\
\hline NOx & Nitrogen Oxides \\
\hline NPK & Nitrogen Phosphorus Potassium (fertiliser) \\
\hline OD & Ozone Depletion \\
\hline ODP & Ozone Depletion Potential \\
\hline OECD & Organisation for Economic Cooperation and Development \\
\hline OVAM & Public Waste Agency of Flanders \\
\hline $\mathrm{P}$ & Phosphorus \\
\hline $\mathrm{PAH}$ & Polycyclic aromatic Hydrocarbons \\
\hline PBS & Polybutylene Succinate \\
\hline PCR & Product Category Rules \\
\hline PE & Polyethylene \\
\hline
\end{tabular}




\begin{tabular}{|c|c|}
\hline PEF & Product Environmental Footprint \\
\hline PEFCR & Product Environmental Footprint Category Rules \\
\hline PET & Polyethylene Terephthalate \\
\hline PFR & Product Functionality Rules \\
\hline PIRA & Packaging Institute Research Association \\
\hline PLA & Polylactic Acid \\
\hline PM10 & Particulate Matter 10 micrometres or less in diameter \\
\hline PMF & Particulate Matter Formation \\
\hline PMFP & Particulate Matter Formation Potential \\
\hline $\mathrm{PO}_{4}$ & Phosphate \\
\hline POF & Photochemical Oxidant Formation \\
\hline POFP & Photochemical Oxidant Formation Potential \\
\hline PP & Polypropylene \\
\hline PS & Polystyrene \\
\hline QSR & Quick Service Restaurant \\
\hline ReCiPe & Method for Impact Assessment \\
\hline RER & Europe (re CoO Ecoinvent) \\
\hline ROW & Rest of the World (re CoO Ecoinvent) \\
\hline $\mathrm{RQ}$ & Research Question \\
\hline SBB & Solid Bleached Board \\
\hline SETAC & Society for Environmental Toxicity and Chemistry \\
\hline SME & Small and Medium-Sized Enterprises \\
\hline $\mathrm{SO}_{2}$ & Sulphur Dioxide \\
\hline TA & Terrestrial Acidification \\
\hline TAP & Terrestrial Acidification Potential \\
\hline TAPPI & Technical Association of the Pulp and Paper Industries \\
\hline TET & Terrestrial Ecotoxicity \\
\hline TETP & Terrestrial Ecotoxicity Potential \\
\hline TNO & Netherlands Organisation for Applied and Scientific Research \\
\hline TRK & Technologically Relevant Knowledge \\
\hline U235 & Uranium-235 \\
\hline UK & United Kingdom \\
\hline ULO & Urban Land Occupation \\
\hline ULOP & Urban Land Occupation Potential \\
\hline UN & United Nations \\
\hline UN CPC & United Nations Central Product Classification \\
\hline UNEP & United Nations Environment Programme \\
\hline
\end{tabular}




\begin{tabular}{l|l}
\hline US CDC & US Centers for Disease Control and Prevention \\
\hline US EDF & US Environmental Defense Fund \\
\hline US EIA & US Environmental Impact Assessment \\
\hline USA & United States of America \\
\hline USDA & US Department of Agriculture \\
\hline VOC & Volatile Organic Compounds \\
\hline VROM & Ministry of Housing, Spatial Planning and the Environment (Netherlands) \\
\hline WD & Water Depletion \\
\hline WDP & Water Depletion Potential \\
\hline XRF & X-ray Fluorescence \\
\hline
\end{tabular}


